\title{
TANIA REGINA TOZETTO MENDOZA
}

\section{Análise da variabilidade genética do Herpesvirus 8 Humano (HHV-8) em indivíduos infectados por HIV com e sem sarcoma de Kaposi}

Tese apresentada ao Instituto de Medicina Tropical de São Paulo da Universidade de São Paulo para obtenção do titulo de Doutor em Ciências.

Área de concentração: Doenças Tropicais e Saúde Internacional

Orientador: Profa. Dra. Camila Malta Romano

\section{São Paulo}

2013 
Ficha catalográfica

Preparada pela Biblioteca do Instituto de Medicina Tropical de São Paulo da Universidade de São Paulo

(c) Reprodução autorizada pelo autor

\section{Tozetto Mendoza, Tania Regina}

Análise da variabilidade genética do Herpesvirus 8 human (HHV8) em indivíduos infectados por HIV com e sem sarcoma de Kaposi / Tania Regina Tozetto Mendoza. - São Paulo, 2013.

Tese (Doutorado) - Instituto de Medicina Tropical de São Paulo da Universidade de São Paulo para obtenção do título de Doutor em Ciências.

Área de concentração: Doenças Tropicais e Saúde Internacional Orientadora: Camila Malta Romano

Descritores: 1. HERPESVÍRUS 8 HUMANO. 2. GENOTIPOS. 3. SARCOMA DE KAPOSI. 4. HIV. 5. VARIAÇÃO GENÉTICA.

USP/IMTSP/BIB-11/2013. 
À DEUS,

Sobretudo. 


\section{A minha querida família}

Aos meus pais Moacir Tozetto (in memoriam) e Judith S. Tozetto, que com tanta dedicação me ensinaram o caminho de fazer o que se ama. Ao meu marido Roberto Mendoza, pelo companheirismo e força em todos os momentos. As minhas sobrinhas e sobrinhos, manos e agregados 


\section{Aos prezados professores,}

Dr. Claudio Sérgio Pannuti e Dra. Vanda Ueda Fick de Souza pela oportunidade e incentivo para desenvolver esse trabalho, pelas orientações, pela confiança, pelas idéias e apoio, sempre com atitudes de humildade e dignidade, que me servem de exemplo profissional e de vida. 
Ao participantes

do estudo, todo meu respeito. 


\section{Agradecimentos}

\section{Trouxeram-me apoio, sem o qual, esse trabalho não seria igualmente possível.}

Tenho uma história, ou pelo menos um momento, mas que fez a diferença, com cada um, para a realização desse trabalho.

A minha prezada orientadora, Dra. Camila Malta Romano, pelo seu espírito crítico e científico, pela forma entusiasmante, competente e objetiva da sua orientação, com confiança, incentivo e apoio sempre que eu chegasse a sua porta, por sinal sempre aberta.

Aos médicos Dra. Lígia Camera Pierrotti e Karim Ibrahim Yaqub pela colaboração tão importante para a composição e ao entendimento do dados clínicos.

Ao Dr. Felix Drexler da Universidade de Bonn, Alemanha e queridos companheiros Adriana Tateno e Rodrigo Merlim, pelo apoio na otimização da obtenção das sequências $K 1$, que aprimoraram esse estudo, pela experiência enriquecedora.

Ao Dr Juan Diego Rojas, biotecnólogo do Instituto de Ciências Biomédicas USP, departamento de microbiologia, que coloborou nas primeiras fases do trabalho, ensinando-me ferramentas de análise de sequências, encorajandome a busca desses novos caminhos.

A banca de qualificação Dr. José Angelo Lauletta Lindoso, Dr. João Renato Pinho, cujas sugestões aprimoraram esse estudo.

Aos prezados companheiros de partilha de conhecimentos e de idéias do grupo do HHV-8, com suas especialidades Laura M. Sumita (Biologia Molecular), Wilton S. Freire (ensaios de imunofluorescência), Dr. Paulo Braz (patologia oral), Dra. Cristina Mendes de Oliveira (análise de dados SIMPLOT e PAUP) e os prezados estagiários e aprimorandos (atuais e que já se formaram) do grupo de HHV-8 Dayne Soares, Roberto M. Ribeiro, Sideny L. Nunes, Wanessa Cardoso, Tatiana Mitiko, Silvia Imura.

A equipe do dia a dia de trabalho no laboratório de Virologia: começando pela minha querida irmã Lucy S. Vilas Boas, com suas sábias idéias, minha incentivadora; e aos preciosos companheiros que sempre me apoiram em tudo que precisei: querida Marli P. Estevam, Cynthia Canto, Luciano Monteiro da Silva, Silvia H. Lima, Maria Carolina Manana F. de Souza, Alvina Clara Felix, Sonia Ap. Anjos Ferraz, Débora Alves dos Santos, Maria Auxiliadora F. Lima, Georgina Silveira P. Neta.

Aos prezados Dra. Maria Cristina Fink e Dr. Paulo Braz pela atenciosa trocas de idéias e na correção da redação do trabalho. 
A chefe do laboratório de Virologia, Dra. Clarisse Machado, sempre com sua postura agregadora entre nós, abriu-me sempre oportunidades de colaboração em seus projetos de pesquisa.

Ao Dr. Expedito José de Albuquerque Luna, pela atenciosa colaboração na análise estatística dos dados.

Aos pesquisadores Dra. Ester Sabino, Dra Dayse Machado pela colaboração em seus trabalhos e Dr. José Eduardo Levi e Dr. Sabri S. Sanabani pelas trocas de idéias.

A prezada Dra. Neila Freitas Viegas, pelo seu profissionalismo que se tranformou em grande motivação e incentivo para realização desse trabalho.

Aos caros colegas do Hemocentro - HC e da Hematologia Tropical - IMTSP Suzete Esdras Ferreira, Jerenice Ferreira, e as prezadas estagiárias Andressa Carvalho, Caetlin Craneck e Tamiris Zulato Tozetto.

A bibliotecária Sônia $P$. Gomes, pela atenção de sempre, orientação e correção bibliográfica.

A Eliane Araújo e Solange Fernandes Ferreira dos Santos, secretárias da pós-graduação, pelo atencioso e competente trabalho.

Ao Dr. João Targino de Araújo e Dra. Rosa Araújo, pela rica experiência em conhecê-los e pelo exemplo de dedicação aos pacientes.

As minhas queridas irmãs do IMTSP Célia R. Furuchó, Ana Maria de Paula, Edite Kanashiro, Jonisi Santos da Silva, Sueli Fátima de Bastos...

A todos os colegas do laboratório de Virologia-IMTSP, pesquisadores, estagiários, aprimorandos, residentes, funcionários, minha admiração e respeito.

Aos colegas e professores dos laboratórios de Imunologia e Sorologia do IMTSP, em que iniciei minha carreira, e tanto os admiro.

A comissão de pós graduação e aos colegas, professores e funcionários do Instituto de Medicina Tropical de São Paulo. Todos, que de uma maneira ou de outra, colaboraram para realização do programa de pós-graduação em Doenças Tropicais e Saúde Internacinal, desde que era apenas um sonho...

Apoio financeiro PROAP, LIM 52 e Laboratório de Virologia-IMTSP-USP na compra de reagentes e infraestrutura. 
Lista de Figuras

\section{SUMÁRIO}

Lista de Quadros

Lista de Tabelas

Resumo

Abstract

1 INTRODUÇÃO

1.1 Panorama histórico: sarcoma de Kaposi e HHV-8 ................................ 2

1.2 Sarcoma de Kaposi, a doença.............................................................. 5

1.2.1 O tecido do tumor............................................................... 5

1.2.2 Manifestações clínicas do SK associado à aids (SK - aids)............ 7

1.2.3 Epidemiologia da doença: sarcoma de Kaposi associado ao HIV na era pré e pós HAART ..................................................... 8

1.2.4 Suscetibilidade para o desenvolvimento do SK ........................... 13

1.2.4.1 Co-infecção HIV e HHV-8 ................................................ 13

1.2.4.2 O caráter multifatorial do SK .......................................... 14

1.3 Herpesvírus 8 humano ................................................................... 16

1.3.1 Epidemiologia da infecção por HHV-8 e vias de transmissão no mundo e no Brasil ................................................................. 16

1.3.1.1 Estudos de soroprevalência do HHV-8 no mundo e no Brasil.... 16

1.3.1.2 Vias de transmissão do HHV-8 ..................................... 19

1.3.2 Classificação do HHV-8 ..................................................... 23

1.3.3 Estrutura do Genoma do HHV-8 ............................................ 25

1.3.4 Programas transcricionais do HHV-8: fase latente e fase lítica. ..... 27

1.3.5 Propriedades biológicas decifradas no genoma do HHV-8............ 29

1.3.6 Enfoque: ORF K1 e ORF K12 do HHV-8................................... 33

1.3.7 Diversidade genética do HHV-8 ............................................. 37

1.3.7.1 Diversidade genética com base na análise isolada de genes ... 37

1.3.7.2 Distribuição geográfica não ubiqua dos genótipos de HHV-8 no mundo e no Brasil............................................ 40

1.3.7.3 A perspectiva em identificar o potencial patogênico associado ao genótipo viral ou a variabilidade genética viral .... 43

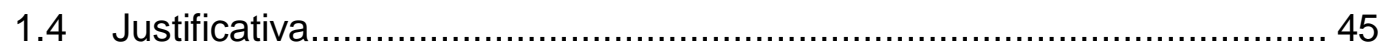

2 OBJETIVOS 46



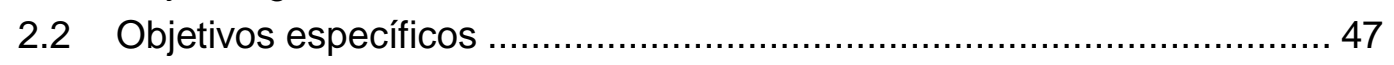

3 CASUÍSTICA E MÉTODOS 49

3.1 Casuística e desenho do estudo .................................................. 50

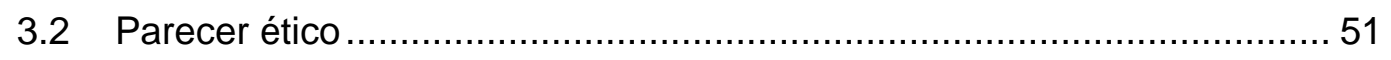

3.3 Definições dos grupos de estudo com e sem SK ................................. 52

3.3.1 Grupo 1 - HIV SK ............................................................. 52

3.3.2 Grupo 2 - HIV não SK (nSK) ……..................................... 53 
3.4 Processamento do material biológico e obtenção, purificação e controle de qualidade do DNA total obtido

3.5 Definição da co-infecção HIV e HHV-8 na ausência do sarcoma de Kaposi....

3.5.1 Método PCR em tempo real ORF 73 ....................................... 54

3.6 Análise Molecular do HHV-8 ............................................................ 56

3.6.1 Amplificação da ORF K1 parcial (K1/VR1 e K1/VR2) e completa do genoma do HHV8 ............................................ 57

3.6.2 Amplificação da ORF K12 do HHV-8...................................... 58

3.6.3 Avaliação dos Produtos de PCR da ORF K1 parcial (K1/VR1, K1/VR2) e completa ou ORF K12......................................... 59

3.6.3.1 Identificação dos Fragmentos de DNA alvo em gel de agarose.... 59

3.6.3.2 Purificação do produto de PCR e Reação de Sequenciamento de DNA 60

3.7 Análises Moleculares e Filogenéticas ................................................. 61

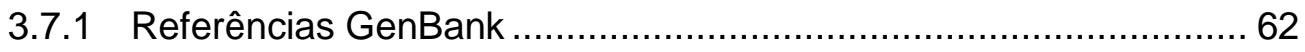

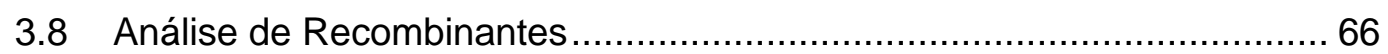

3.9 Mutações sinônimas e não sinônimas................................................. 66

3.10 Análise de Polimorfismos de um Único Nucleotídeo - SNP (Single

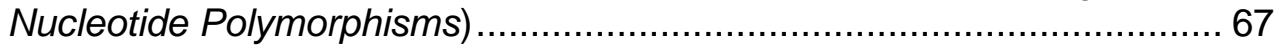



4 RESULTADOS 68

4.1 Avaliação dos produtos de PCR e seleção das amostras de DNA/HHV-8 positivas 70

4.1.1 Avaliação dos Fragmentos de DNA de HHV-8 da ORF K1 e ORF K12 70

4.1.2 Semi-quantificação, purificação do produto de PCR e padrão de qualidade das sequências de DNA obtidas ................................... 72

4.2 Indivíduos infectados por HIV com diagnóstico conclusivo de SK ............... 72

4.2.1 Sequências de DNA/HHV-8 dos loci da ORF K1 e ORF K12 no

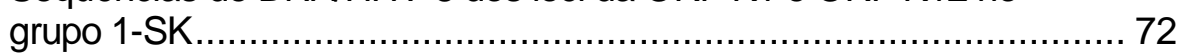

4.3 Indivíduos infectados por HIV sem histórico de SK .............................. 73

4.3.1 Definição da infecção por HHV-8 …....................................... 73

4.3.2 Sequências de DNA/HHV-8 dos loci da ORF K1 e ORF K12 no grupo 2-nSK

4.4 Descrição geral das características demográficas e laboratoriais dos



4.4.1 Homens que fazem sexo com homens (HSH) ........................... 77

4.4.2 Tempo de infecção por HIV e aids .............................................. 78

4.5 Anáise filogenética baseada nas sequências de DNA do HHV-8 dos

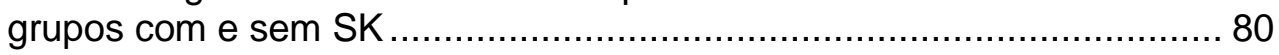

4.5.1 Avaliação do desempenho dos diferentes primers do locus K1 na análise de genótipos ......................................................... 80

4.5.2 Classificaçao filogenética das Sequências de DNA de HHV-8 ....... 82 
4.6 Relação dos genótipos (subtipos) e subgenótipos (intratipos/intertipos) de HHV-8 com as diferentes características dos grupos de estudo.

4.6.1 Presença ou não do SK .............................................................. 90

4.6.2 Estadio de SK ..................................................................... 91

4.6.3 Análises da Evolução Clínica de SK e dos níveis de CD4+ ........... 93

4.6.4 Categorias de risco de transmissão de HIV ................................... 94

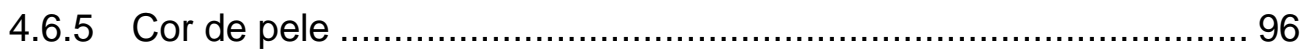

4.6.6 Quadro clínico de adoecimento com aids.................................. 97

4.6.7 Infecção por HHV-8 e carga viral de HHV-8 em indivíduos sem SK... 97

4.6.8 Diagnóstico de HIV ................................................................... 99

4.6.9 Tempo de uso de ART ........................................................ 101

4.6.10 Carga viral do HIV ................................................................ 103

4.6.11 Faixa etária e gênero ......................................................... 103

4.7 Característica de variabilidade das sequências de DNA de HHV-8 ........... 104

4.7.1 Características sugestivas de recombinação ............................. 105



4.7.3 Perfil de Mutações. Substituição sinônima e não sinônima .......... 108

4.7.4 Variabilidade da ORF K1 de HHV-8 quando houve sequências de DNA/HHV-8 obtidas em mais de uma amostra biológica em ocasiões diferentes do mesmo indivíduo (variabilidade intrahospedeiro) ................................................................... 110

4.7.5 Polimorfismos de um único nucleotídeo (SNPs) no locus K12 ..... 111

4.7.6 Mutações nas sequência de aminoácidos do locus K12.............. 114

5 DISCUSSÃO 116

6 CONCLUSÃO 143

7 REFERÊNCIAS 146

ANEXO 173 


\section{Listas}

\section{FIGURAS}

Figura 1 - A diferencial distribuição do HHV-8 baseada em estudos soroepidemiológicos

Figura 2 - Árvore filogenética dos herpesvírus............................................. 25

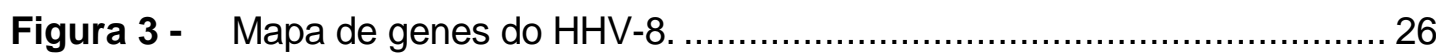

Figura 4 - Destaque da glicoproteína transmembrana codificada pela ORF K1 do HHV-8

Figura 5 - Predição da estrutura da sequência de aminoácidos (289 aminoácidos) codificada pela ORF K1 do HHV-8

Figura 6 - Distribuição geográfica dos principais genótipos do HHV-8, baseada na reconstrução filogenética do gene K1

Figura 7 - Desenho do estudo: seleção dos indivíduos infectados por HIV pertencente aos grupos com SK.....

Figura 8 - Esquema da coordenada dos primers para amplificação dos loci investigados nesse estudo. A. Locus ORF K1. B. Locus ORF K12.

Figura 9 - Seleção dos 75 indivíduos infectados por HIV, com SK (grupo 1, $\mathrm{n}=34$ ) e sem SK (grupo 2, $\mathrm{n}=41$ )

Figura 10 - Padrão de migração por eletroforese em gel de agarose $1,5 \%$ de fragmentos de DNA alvo de HHV-8.

Figura 11 - Semi-quantificação de DNA 72

Figura 12 - A. Perfil de amplificação da ORF 73 HHV-8 por PCR em tempo real. B. Curva.

Figura 13 - Distribuição dos indivíduos co-infectados HIV e HHV-8, conforme categoria de carga viral de HHV-8/ORF 73.

Figura 14 - Proporção das categorias risco de adquirir HIV. 78

Figura 15 - Apresentação do alinhamento $\left(1^{\mathrm{a}}\right.$ e $2^{\mathrm{a}}$ parte $)$ de protótipos de sequência de DNA do locus K1 do HHV-8 e a área de divergência de nucleotídeos em destaque na região dos primers.

Figura 16 - A - Árvore filogenética construída a partir de sequências de DNA do locus K1 completo e parcial (K1/VR1) do HHV-8.

Figura 16 - B - Árvore filogenética construída a partir de sequências de DNA do locus K1 completo e parcial (K1/VR2) do HHV-8. 
Figura 17 - Árvore filogenética construída a partir das sequências de DNA de HHV-8 do locus K12

Figura 18 - Comparação dos valores da carga (log) de HHV-8 dos 41 indivíduos do grupo 2-nSK

Figura 19 - Evento de recombinação detectado pelo programa SIMPLOT......... 105

Figura 20 - Programa SISCAN do pacote RDP ............................................... 106

Figura 21 - Regiões de deleção variando de 12, 15 e 39 nucleotídeos na região K1/VR2 do HHV-8 presentes em variantes do HHV-8 descritas nesse estudo, visualizadas no programa Mega 5 ............ 107

Figura 22 - Avaliação da estimativa $\mathrm{dN}^{-} \mathrm{dS}$ nas sequências com extensão de 289 aminoácidos (gene K1) de isolados de HHV-8.

Figura 23 - Distribuição da frequência de amostras positivas para cada um dos 26 sítios polimórficos, de acordo com sua posição nucleotídica (117417 a 118055) ao longo do locus K12.

Figura 24 - Conjunto das Sequências de aminoácidos do locus K12 dos grupos 1 e 2 e protótipos de diferentes regiões geográficas. 


\section{QUADROS}

Quadro 1 - Identificação dos genótipos dos isolados de HHV-8 obtidos a partir dos loci K1 completo (K1) e/ou parciais (K1/VR1, K1/VR2) e/ou K12 de cada um dos indivíduos infectados por HIV do grupo 1 SK

Quadro 2 - Identificação dos genótipos dos isolados de HHV-8 obtidos a partir dos loci K1 completo (K1) e/ou parciais (K1/VR1, K1/VR2) e/ou K12 de cada um dos indivíduos infectados por HIV do grupo 2 nSK 


\section{TABELAS}

Tabela 1 - Primers e sonda marcada segundo Krishnan (2004) para uso em PCR em tempo real

Tabela 2 - Conjunto de primers usados na amplificação completa e parcial da ORF K1 do HHV8

Tabela 3 - Primers para amplificação da ORF K12: um fragmento de 752 pb (primeiro round) e alternativamente, 646 e $407 \mathrm{pb}$ (segundo round) da ORF K12 (T0.7)

Tabela 4 - Protótipos de referência da ORF K1 do HHV-8 e o respectivo genótipo/subgenótipo da ORF K1, segundo dados obtidos do GenBank

Tabela 5 - Protótipos de referência da ORF K12 (T0.7) do HHV-8 e o respectivo genótipo/subgenótipo da ORF K12 e K1, segundo dados obtidos do GenBank....

Tabela 6 - Dados demográficos e laboratoriais dos 75 indivíduos infectados por HIV grupo 1 - SK e grupo 2 - nSK....

Tabela 7 - Distribuição e frequência das diferentes categorias de risco de transmissão para adquirir HIV entre o grupos com e sem SK

Tabela 8 - Distribuição do número de indivíduos infectados por HIV, Grupo 1-SK e grupo 2- nSK, de acordo com a categoria de Intervalo de tempo entre a data de admissão no protocolo de estudo (data da coleta do material biológico) e o diagnóstico da infecção por HIV, aids e SK

Tabela 9 - Distribuição do número de indivíduos com e sem manifestação de SK de acordo com os genótipos (subtipos) e subgenótipos (intertipos/intratipos) de HHV-8

Tabela 10 - Distribuição dos genótipos (subtipos) de HHV-8 em relação a presença da forma visceral e não visceral no grupo 1 - SK. Comparação com a distribuição dos subtipos de HHV-8 no grupo 2 - nSK

Tabela 11 - Distribuição dos subgenótipos de HHV-8 de acordo com o estadio de SK.

Tabela 12 - Distribuição do número de indivíduos de acordo com a presença de episódio de piora do SK e subgenótipos de HHV-8 presentes no grupo 1-SK. Comparação com os subgenótipos do HHV-8 do grupo 2-nSK

Tabela 13 - Distribuição do número de indivíduos HSH ou não HSH e subtipos de HHV-8 entre os grupos de estudo. 
Tabela 14 - Distribuição dos genótipos (subtipos) de HHV-8 entre os indivíduos do grupo 1 - SK e grupo 2 - nSK, de acordo com a cor de pele.

Tabela 15 - Comparação do log da carga viral de HHV-8 (por $\mu \mathrm{g}$ de DNA/mL) de acordo com os subgenótipos de HHV-8 detectados na saliva de indivíduos HIV sem SK, grupo 2 - nSk

Tabela 16 - Distribuição do número de indivíduos do grupo 1 -SK conforme intratipos de HHV-8 e ano do diagnóstico do HIV entre o ano de 1987 a 2000.

Tabela 17 - Distribuição do número de indivíduos do grupo 2 - nSK conforme subgenótipos de HHV-8 (intratipos do locus K1) e ano do diagnóstico do HIV entre o ano de 1987 a 2007

Tabela 18 - Distribuição dos genótipos/subgenótipos de HHV-8 segundo o tempo de uso de ART até a ocasião da admissão do estudo

Tabela 19 - Distribuição do número de genótipos de HHV-8 em relação a carga viral de HIV avaliado no grupo 1 com SK e grupo 2 sem SK. Subrescrito ao número estão identificados os subgenótipos

Tabela 20 - Distribuição do número de indivíduos de acordo com a faixa etária e genótipos e subgenótipos de HHV-8

Tabela 21 - Distribuição do número de sequências de DNA de HHV-8 positiva para determinado SNP com base no genoma de referência do GenBank U75698 e sequências de HHV-8 de indivíduos do grupo 1-SK e grupo 2-nSK e protótipos....

Tabela 22 - Alguns principais estudos sobre a variabilidade genética do HHV-8 baseada no locus $\mathrm{K} 1$, de diferentes regiões do mundo, inclusive do Brasil, apontando a casuística e o tamanho de fragmento de DNA de HHV-8 sequenciado 


\section{RESUMO}

Tozetto-Mendoza TR. Análise da variabilidade genética do Herpesvírus 8 Humano (HHV-8) em indivíduos infectados por HIV com e sem sarcoma de Kaposi (tese). São Paulo: Instituto de Medicina Tropical de São Paulo da Universidade de São Paulo. 2013. 174p.

Introdução. O HHV-8 (herpesvírus 8 humano) é o agente etiológico do sarcoma de Kaposi (SK). Diferentemente dos outros herpesvírus, o HHV-8 é distribuído de modo não ubíquo ao redor do mundo. São sete os principais genótipos de HHV-8, de acordo com o padrão de variabilidade da ORF K1: A, B, C, D, E, F e Z. Estudos da variabilidade genética do HHV-8 poderão trazer melhores interpretações sobre 0 potencial patogênico dos genótipos de HHV-8 e das variações genotípicas funcionais. Dados sobre a variabilidade genética do HHV-8 no Brasil, em que o SK é associado ao HIV, permanecem escassos. Pelo nosso conhecimento, esse é o primeiro estudo que compara a variabilidade genética de HHV-8 em indivíduos infectados por HIV com SK e sem SK no Brasil. Objetivo. O estudo visou analisar a variabilidade genética do HHV-8 entre indivíduos infectados por HIV com SK e sem histórico de SK. Métodos. Sequências de DNA de HHV-8 foram investigadas em amostras criopreservadas de células mononucleares do sangue periférico a partir de 37 indivíduos infectados por HIV com SK (grupo 1); e de amostras de saliva de indivíduos sem SK (grupo 2), as quais foram selecionadas por meio da detecção positiva de DNA/ORF73/HHV-8 a partir de um total de 751 indivíduos. Dados demográficos e clínicos do estadio e evolução do SK, assim como parâmetros laboratoriais foram caracterizados. As análises moleculares e reconstruções filogenéticas foram baseadas nas ORFs K1 e K12 do HHV-8. Resultados. Foram obtidas sequências de DNA dos loci K1 e/ou K12 de 75 indivíduos, 34 indivíduos do grupo 1 e 41 do grupo 2. O sistema de primers empregado foi capaz de detectar os genótipos $\mathrm{A}, \mathrm{B}, \mathrm{C}, \mathrm{F}$ e amplo perfil de subgenótipos de $\mathrm{K} 1 / \mathrm{HHV}-8$. Os dados não mostraram associação de genótipos de HHV-8 com a presença de SK ou estadio de SK. Todavia, o subgenótipo B1 predominou naqueles em que não houve registro de piora de SK $(p=0,04)$. Os subgenótipos B1 e C3 foram igualmente predominantes em ambos os grupos. As frequências do genótipos A foram de $24 \%$ e $12,2 \%$ e dos genótipos B e C foram de 34,1 e 35,3\%, nos grupos 1 e 2, respectivamente. $\mathrm{O}$ genótipo $\mathrm{F}$ foi descrito pela primeira no Brasil, um caso de cada grupo. Um amplo perfil de subgenótipos de C no grupo 2 sem SK foi encontrado (C1, C2, C3, C5 e C7). Subgenótipos K1 C5 e C7, exclusivos do grupo 2 (7\%), foram confirmados como recombinantes. Não houve variabilidade genotípica de HHV-8 em amostras biológicas diferentes do mesmo indivíduo em oito casos estudados. Sítios polimórficos (6/59) em regiões codificadoras de miRNA do locus K12 foram observados, sendo $70 \%$ presentes exclusivamente em sequências de HHV-8 do grupo com SK e protótipos de SK. Conclusão. Embora não houvesse associação entre genótipos de HHV-8 e presença ou estadio de SK, o subgenótipo B1 foi significativamente relacionado ao melhor prognóstico de SK. Alguns recombinantes foram observados no locus K1 de HHV-8 em indivíduos do grupo 2 sem SK. A presença de SNPs em regiões codificadoras de miR12-12 e miR12-10 predominou em sequências de HHV-8 de indivíduos com SK, grupo 1, e protótipos de SK epidêmico, endêmico e clássico. A escoha de primers foi importante para garantir a amplificação de todos os genótipos e amplo perfil de subgenotipos de HHV-8.

Descritores: Herpesvirus 8 humano. Sarcoma de Kaposi. Genótipos. Variabilidade genética. Sarcoma de Kaposi associado ao HIV. 


\section{ABSTRACT}

Tozetto-Mendoza TR. Analysis of the genetic variability of human herpesvirus 8 (HHV-8) of HIV-infected individuals with and without Kaposi's sarcoma (thesis). São Paulo: Instituto de Medicina Tropical de São Paulo da Universidade de São Paulo. 2013. 174p.

Introduction. HHV-8 (Human Herpes Virus 8) is the etiological agent of Kaposi's sarcoma (KS). Unlike other herpesviruses, the distribution of HHV-8 is not so ubiquitous around the world. There are seven major HHV-8 genotypes, according to the variability pattern of the ORF K1: A, B, C, D, E, F and Z. Studies on the genetic variability of HHV-8 may help to better understand the pathogenic potential of HHV-8 genotypes and their functional genotypic variations. Data on the genetic variability of HHV-8 in Brazil, where KS is associated with HIV infected people, remain scarce. To our knowledge, this is the first study comparing the genetic variability of HHV-8 among HIV-infected individuals with KS and without KS in Brazil. Objective. The study aimed to analyze the genetic variability of HHV-8 among HIV-infected individuals with and without KS. Casuistry and Methods. HHV-8 DNA sequences were obtained from samples of cryopreserved peripheral blood mononuclear cells from 37 individuals infected with HIV-KS (group 1); and saliva from individuals without KS (group 2) who were selected by means of detection of positive DNA/ORF73/HHV-8 from a total of 751 individuals. Demographic and clinical data (stage and progression of KS), as well as laboratory parameters were characterized. Molecular analysis and phylogenetic reconstructions were based on sequences of the ORFs $\mathrm{K} 1$ and/or K12 of HHV-8. Results. K1 and/or K12 DNA sequences of HHV-8 were obtained from 75 subjects, 34 from group 1 and 41 from group 2 . The primer system used was able to detect the genotypes $A, B, C, F$ and a wide profile of HHV- $8 \mathrm{~K} 1$ subgenotypes. Data showed no association of genotypes with the occurrence of KS or with visceral KS either. However, subgenotype B1 predominated in individuals who did not report any progression of $K S(p=0.04)$. Subgenotypes B1 and C3 were equally prevalent in both groups. Genotype A frequencies were $24 \%$ and $12.2 \%$ and genotypes $B$ and $C$ were 34.1 and $35.3 \%$ in groups 1 and 2 , respectively. We also described here for the first time the genotype $\mathrm{F}$ of HHV-8 in Brazil. A wide profile of subgenotypes $\mathrm{C}(\mathrm{C} 1, \mathrm{C} 2, \mathrm{C} 3, \mathrm{C} 5$ and $\mathrm{C} 7)$ in the group without KS was found. HHV-8 K1 DNA sequences of group $2(7 \%)$ belonging to subgenotypes $\mathrm{C} 5$ and $\mathrm{C} 7$ were confirmed as recombinants. Our findings did not show virus variability in the same patient in samples collected at different times or from different biological material in the eight cases studied here. There was no statistical difference regarding the presence/absence of a given SNP from locus K12 between groups with and without KS. However, there were a total of 6/59 polymorphic sites in coding regions of miRNA, $70 \%$ of which present only in the HHV-8 DNA sequence of group with KS and KS prototypes. Conclusion. Although there was no association between HHV-8 genotypes and the presence of KS and KS clinical stage, subgenotype B1 was significantly related to the absence of progression of KS. Some recombinants in K1/HHV-8 locus were observed in the group without KS. The presence of SNPs in coding regions of miR12-12 and miR1210 predominated in sequences of HHV- 8 of SK cases (group 1) and of epidemic, endemic and classic KS prototypes. The choice of primers was essential to ensure amplification of all HHV- 8 genotypes and wide profile de subgenotypes.

Keywords: Human Herpesvirus 8. Kaposi's Sarcoma. Genotypes. Genetic Variability. Kaposi's Sarcoma associated with HIV. 


\subsection{Panorama histórico: sarcoma de Kaposi e HHV-8}

O sarcoma de Kaposi (SK) é descrito como um tumor que afeta sangue e vasos linfáticos (Safai and Good, 1981; Pyakurel et al., 2006), caracterizado por lesões neoplasias cutâneas ou viscerais. São descritas quatro classificações clínicoepidemiológicas do sarcoma de Kaposi: SK clássico; SK endêmico (Slavin et al., 1970; SK iatrogênico (Schwartz et al., 2008) e SK epidêmico ou associado à aids (SK-aids) (Boshoff et al., 1995).

A doença clássica do sarcoma de Kaposi foi descrita pela primeira vez há quase um século e meio com a denominação de "sarcoma hiperpigmentado múltiplo idiopático" de pele (Kaposi, 1872), embora a doença tenha recebido a denominação de sarcoma de Kaposi somente em 1912 em homenagem ao dermatologista hungaro Moritz Kaposi, 10 anos após a sua morte (Van e Quint, 2011). A doença clássica de evolução geralmente indolente em idosos foi relatada especialmente em homens judeus de origem Ashkenazi em Viena, Austria e predominantemente na região do mediterrâneo e leste Europeu (Iscovich et al.,2000; Guttman-Yassky et al., 2003; Dal Maso et al., 2009). Um século depois, a partir da disponibilidade dos registros de câncer na África, uma forma mais agressiva em crianças foi descrita em algumas regiões da África equatorial (Slavin, 1970; Serwadda et al., 1986; Oettlé, 1962; Templeton, 1981; Buonaguro et al., 2003). Esta nova forma de apresentação clínicoepidemiológica foi denominada SK endêmico. As investigações epidemiológicas iniciais já apontavam uma distribuição geográfica não ubíqua, levando a hipótese da existência de um fator exógeno etnicamente importante.

Myers et al. (1974) descreveu um dos primeiros casos de SK iatrogênico associado ao transplante renal e posteriormente outros casos foram descritos, de modo que a relação inversa entre a condição de imunocompetência e evolução do SK foi então evidenciada por diferentes grupos de pesquisa (Buonaguro et al., 2003; 
Stribling et al., 1978; Penn, 1983; Buonaguro et al., 2003; Tessari et al., 2006; Tessari, et al, 2013). O desenvolvimento do SK em receptores de transplante de órgãos sólidos estava associado ao tratamento com drogas imunossupressoras, havendo remissão do mesmo após a suspensão do tratamento.

O SK deixou de ser um tumor raro para disseminar-se por todos os continentes a partir da década de 80 , paralelamente ao surgimento da sindrome da imunodeficiência adquirida (aids) em homens que fazem sexo com homens (HSH) infectados pelo vírus da imunodeficiência adquirida (HIV). Uma manifestação cutânea foi a primeira evidência do sarcoma de Kaposi associado à aids (SK-aids). O "beijo violeta do anjo da morte" foi a denominação dada pelo dramaturgo americano Tony Kushn à lesão cutânea do SK, que passou a estigmatizar os indivíduos acometidos pela aids (sigla do inglês, Acquired Immunodeficiency Syndrome). As primeiras evidências do caráter epidemico do SK-aids foram relatadas em estudos em jovens $\mathrm{HSH}$ com aids proveniente de Nova lorque e Los Angeles (Hymes et al., 1981; Gooding, 1992). Entre os indivíduos infectados pelo HIV, a constatação de que o risco de desenvolver SK era 20 vezes maior entre HSH levou à tese de que o fator exógeno desencadeante do SK fosse de origem infecciosa e transmitida sexualmente (Gottlieb et al., 1981; Beral et al., 1990). Assim, SK epidêmico ou SK-aids passou a representar o primeiro indicador da epidemia da aids causada pelo HIV (Beral et al., 1990; Biggar et al., 1987; Buonaguro et al., 2003). A pandemia da aids trouxe um quadro alarmante: o sarcoma de Kaposi passou a ser um dos tumores mais comuns que afetam adultos e crianças em muitos países, especialmente da África, com significante morbidade e mortalidade (Parkin, 2006; Wabinga et al, 1993; Sinfield et al.,2007).

Apesar do sarcoma de Kaposi ter sido descrito há mais de um século, a etiologia da doença manteve-se desconhecida e questionada por longo tempo. Há aproximadamente quatro décadas atrás, os herpesvírus foram sugeridos como envolvidos na evolução do sarcoma de Kaposi (Giraldo et al., 1972; Giraldo et al., 1980). 
Todavia, somente em 1994, que Yuan Chang, Patrick Moore e seus colaboradores detectaram de forma inédita a sequência de DNA ou ácido desoxirribonucleico (do inglês, Deoxyribonucleic acid) de um novo gamma-herpesvirus, hoje denominado HHV-8 ou KSHV (Herpesvírus 8 humano ou Herpesvírus Humano Associado ao sarcoma de Kaposi), invariavelmente presente em lesões de SK de indivíduos infectados por HIV (Chang et al, 1994).

Hoje, a etiologia viral do SK está consensualmente confirmada. O HHV-8 é considerado o agente etiológico de todas as formas clínico-epidemiológicas do SK (Chang et al., 1994; Russo et al., 1996; Buonaguro et al., 2003; Rezaee et al., 2006; Tornesello et al 2010). Além do sarcoma de Kaposi, a infecção por HHV-8 também está associada ao Linfoma de Efusão Primário (PEL, do inglês Primary Effusion Lymphoma) e a doença Multicêntrica de Castleman (MCD, do inglês Multicentric Castleman Disease) (Cannon et al., 2000; Ablashi et al., 2002; Sunil et al., 2010; Uldrick et al., 2012). Recentemente, uma nova entidade sistêmica tem sido associada a infecção lítica desse vírus, denominada Síndrome de Citocinas Inflamatórias associada ao KSHV (do inglês, KICS ou KSHV inflammatory cytokines syndrome) (Uldrick et al., 2010, Polizzotto et al., 2012).

O desenvolvimento de terapias combinadas bloqueando a replicação do HIV trouve profundas mudanças na incidência da manifestação do SK associado à aids (Fairall et al., 2008; Restrepo e Ocanzionez, 2011; Semmere et al, 2012; Armstrong et al, 2013; Chokunonga et al., 2013). O impacto dessas intervenções terapêuticas ainda não pode ser totalmente previsto. No entanto, o aumento da sobrevida de indivíduos vivendo com aids tem ocorrido, concomitantemente à redução da incidência de SK. Essa redução da incidência da doença não acompanha os dados soroepidemiológicos, que têm indicado que a exposição ao HHV-8 excede a ocorrência de SK (Biggar et al., 2000; Whitby et al, 2004; Uldrick e Whitby, 2011). A redução do SK não parece estar relacionada somente a terapia antirretrovial altamente eficaz (comumente denominada HAART, de Highly Active Antiretroviral 
Therapy), visto que cada vez mais tem se relatado a persistência de SK mediante infecção prolongada por HIV mesmo sob uso de tal terapia (Maurer et al., 2007; Nguyen et al., 2008; Krown et al., 2008; Stebbing et al., 2008).

\subsection{Sarcoma de Kaposi, a doença}

\subsubsection{O tecido do tumor}

O presença do HHV-8 é imprescindível para o processo neoplásico, deflagrando o desenvolvimento de um microambiente inflamatório tecidual cujas características histológicas são indistinguíveis entre as quatro formas clínicoepidemiológicas do SK. Consistem de células tumorais fusiformes com proliferação anormal de vasos e extravasamento de glóbulos vermelhos com depósitos de hemosiderina e um acentuado infiltrado inflamatório no início do desenvolvimento das lesões (Gottlieb et al., 1981; Friedman-Kien, 1981, Safai et al., 1985, Mesri et al., 2010). O tipo celular mais comum em lesões nodulares é a spindle cell ou célula fusiforme. As células endoteliais infectadas por HHV-8, sob descontrole imunológico ou sob estímulos ainda não precisamente estabelecidos, passam a expressar fatores angiogênicos que, em sua grande maioria, são marcadores endoteliais, incluindo CD31, CD34 e do Fator VIII, mas também os marcadores do endotélio linfático, tais como o receptor do fator de crescimento endotelial vascular 3 (VEGFR3), vaso linfático hialuronano endotelial 1 (LYVE1), D2-40 e podoplanina (Jussila et al., 1998; Dupin et al., 1999a). No entanto, algumas células fusiformes também expressam marcadores de células dendríticas (Fator XIII), macrófagos (CD68) ou de células de músculo liso, levando à teoria de que essas células não representam um tipo celular uniforme (Roth et al., 1992). Sob a visão ultraestrutural, 
as células fusiformes têm características tanto endoteliais linfáticas quanto vasculares (Orenstein et al., 2008). Mesri et al. (2010) sugeriram através de observações in vitro que o HHV-8 infecta células precursoras endoteliais circulantes, programando-as para uma linhagem linfática, e ao contrário, a infecção de células linfáticas por HHV-8 leva a reprogramação para células vasculares sanguíneas (Hong et al., 2004; Wang et al., 2004). A infecção de células vasculares sanguíneas por HHV-8 reativa o programa embrionário de diferenciação linfática, então o sarcoma de Kaposi passa a expressar numerosos genes de célula endotelial linfática (Aguilar et al., 2012).

Embora o nome sarcoma possa indicar uma similaridade com os tradicionais tumores mesenquimais, de fato há diferenças nítidas entre essas neoplasias. As diferenças microscópicas revelaram que, ao contrário da maioria dos cânceres, que são histologicamente monoclonais, as lesões no SK exibem uma notável diversidade de tipos de celulares, cujas proporções variam de acordo com o estadio da doença. Os primeiros focos reconhecíveis de SK são lesões planas na derme que exibem células $T$, células $B$, macrófagos e abundante neovascularização, com características de tecido de granulação que é típica dos cânceres em geral. Nessa fase inicial, a angiogênese é nítidamente observada nas lesões macroscópicas avermelhadas. Surgem as células fusiformes ou spidlle cells, que virão a dominar a lesão em seus estágios posteriores. Sucessivamente, o SK da derme progride para o estadio de placa - em que a lesão é mais endurecida, muitas vezes edematosa, e mais intensamente vermelha ou mesmo de coloração violácea. As lesões podem progredir para a fase nodular, caracterizada por massas visíveis repletas de células fusiformes e ainda intensa presença de células inflamatórias (Ganem, 2010). 


\subsubsection{Manifestações clínicas do SK associado à aids (SK - aids).}

As lesões do SK são estadiadas clinicamente conforme a classificação adotada pelo "AIDS Clinical Trials Groups" (ACTG), sendo esta classificação frequentemente usada como referência para a medida da extensão da doença clínica (Krown et al, 1997). Desde a introdução da HAART, tem sido necessário estabelecer um refinamento e adaptação dos critérios de estadiamento do ACTG, a fim de que se possa atingir a informação prognóstica (Nasti et al., 2003). Segundo o sistema de estadiamento proposto para definir o prognóstico do SK, pacientes com pior prognóstico são caracterizados por uma maior extensão do tumor, contagem de linfócitos T CD4+ < 200 células $/ \mathrm{mm}^{3}$, e doença sistêmica associada (Krown et al., 1989). As lesões SK-aids descritas como mais agressivas, tais como linfoadenopatia ou SK visceral, são resistentes à terapêutica em mais de $50 \%$ dos casos (Tornesello et al., 2010) e a medida da extensão da lesão no contexto de HAART tem sido o critério mais adequado para a definição do prognóstico de SK, a despeito da contagem de células CD4+ (Nasti et al., 2003). Ainda segundo Nasti et al., 2003, o envolvimento pulmonar destacou-se como um sinal de agressividade do curso clínico e representa o estadio mais tardio da doença.

Das 4 formas clínico-epidemiológicas do SK, o SK - aids é o mais frequente e mais agressivo, e sua evolução varia desde um envolvimento cutâneo restrito e insidioso até um quadro de lesões cutâneas localmente agressivas ou disseminadas e acometimento visceral, de rápida progressão (Hymes et al., 1981; Mesri et al., 2010; Chokunonga et al., 2013 ).

A manifestação cutânea do SK-aids, presente em $85 \%$ dos pacientes, é definida como forma mucocutânea disseminada. As lesões assumem diferentes aspectos - planas, nodulares e vegetantes, usualmente múltiplas, que progridem rapidamente. Predominantemente, o SK-aids afeta membros inferiores e braços, genitália e face (Dezube,1996). O estadiamento do SK é avaliado sistematicamente 
por observação endoscópica, revelando lesão tumoral em trato gastrintestinal em $80 \%$ dos casos de SK-aids (Friedman et al., 1985). loachim et al (1995) observaram que um terço dos pacientes apresentaram acometimento de linfonodos e da cavidade oral na autopsia. A manifestação pulmonar pode localizar-se na parede do brônquio, no parênquima ou pleura (Huang et al., 1996).

Diferentes esquemas de estadiamento do tumor baseados primariamente na sua extensão já foram propostos. Krigel et al. (1983) classificaram os pacientes em quatro estadios: I: lesões cutâneo-mucosas localizadas indolentes (ocorrendo predominantemente na forma clássica); II: lesões cutâneo-mucosas localmente invasivas (predominante no SK endêmico); III: lesões cutâneo-mucosas disseminadas, incluindo doença mucosa em trato gastrointestinal; IV: lesões cutâneo-mucosas com envolvimento visceral ou acometimento da cavidade oral em SK-aids. Mitsuyasu e Groopman (1984) propuseram outro esquema de classificação, específico para os pacientes com SK associado à aids, também com quatro estadios: I: lesões cutâneomucosas em uma área anatômica; II: lesões cutâneo-mucosas em mais de uma área anatômica; III: lesão visceral; IV: lesões cutâneo-mucosas e viscerais.

\subsubsection{Epidemiologia da doença: sarcoma de Kaposi associado ao HIV na era pré e pós HAART}

Desde a descoberta da sua etiologia viral há quase 20 anos, o SK tem se tornado um dos mais importantes tumores induzidos por vírus em todo mundo, sendo o quarto tumor mais comum causado por um agente infeccioso, além dos tumores gástricos, do útero e hepáticos (Martin, 2007). Antes da epidemia do HIV, o SK era uma doença que afetava homens, com extrema variação de incidência em populações especificas. Todavia, o quadro epidemiológico do SK tem se tornado complexo e a incidência de SK tem mudado desde a dispersão mundial do HIV e 
posteriormente após a disponibilidade do uso de HAART, particularmente no continente africano.

Na década de 90, a incidência de SK foi de 1 em 100.000 na população em geral, mas foi de 1 em 20 em indivíduos infectados por HIV, subindo para quase 1 em 3 entre HSH infectados por HIV antes da era HAART (Gallo, 1998; Beral et al., 1990). Outrossim, populações endêmicas para SK sofreram um drástico aumento na incidência do tumor logo após a epidemia da aids. Quase $50 \%$ dos indivíduos que adquiriram HHV-8, com infecção por HIV pré-existente, desenvolveram SK. Contudo, de acordo com Nasti et al., 2003, as infecções oportunistas foram as mais comuns causas de morte na era pré-HAART, pois o comprometimento imunológico levou os pacientes à complicações infecciosas decorrentes da aids e ao óbito mais rapidamente do que a progressão do SK em si.

Em regiões em que o SK é endêmico e não há terapia antirretroviral amplamente distribuída, SK foi considerado o mais comum tumor em adultos. Em Uganda, a incidência de SK aumentou de 1964 a 1968 e 1989 a 1991, atingindo 20 vezes mais homens (Wabinga et al., 1993). Em Zimbabwe, onde é epidêmico, o SK foi o câncer mais comum em adultos, sendo o mais prevalente em homens ( $40 \%$ de todos os cânceres) e o segundo mais comum em mulheres ( $18 \%$ de todos os cânceres), mas também atingiu crianças (10\% de todos os cânceres) (Chokunonga et al., 2000).

A incidência do SK-aids começou a mudar a partir de 1996, inclusive com expressiva redução da incidência com a introdução das terapias antirretrovirais, uma combinação de drogas que com alta efetividade de controla a replicação do HIV (Biggar et al., 2007; Engel et al., 2006). Ainda assim, a ocorrência do SK foi estimada em torno de 65.000 casos, ou aproximadamente $1 \%$ de todos os casos diagnosticados de câncer em 2002 (Parkin, 2006). 
Houve redução da mortalidade dos pacientes infectados por HIV na era HAART em países de melhores recursos econômicos, porém também foi evidenciado, embora mais lentamente, o alcance de mais de 5 milhões de pacientes sob uso de HAART na África subsaariana, com uma redução global da mortalidade quase comparável aos países considerados mais ricos (Fairal et al., 2008; Semeere et al, 2012).

Um estudo mais abrangente abordou 20 anos de registro de câncer (1991-2010) na população negra de Harare (Zimbabwe) e apontou um expressivo declínio da frequência de SK, que coincidiu com contínuas mudanças socioambientais nessa região intensamente afetada pela epidemia da aids, cuja prevalência de HIV aumentou para o máximo de 26,5 \% em 1997 até cair para 13,1\% em 2011 (Chokunonga et al., 2013). Ainda assim, nesse longo período, o SK continuou altamente prevalente. Os tipos de cancer mais comuns em homens foram o sarcoma de Kaposi (34,6\%), o câncer de próstata (10,7\%), de fígado (7,6\%) e de esôfago (6,0\%); enquanto que em mulheres, o cancer do colo do útero foi o mais comum (24,6\% dos casos), seguido de sarcoma de Kaposi $(17,4 \%)$ e câncer de mama $(10,4 \%)$.

Nos Estados Unidos da América (EUA), o SK associado à aids tem sido apontado como a neoplasia mais frequente em bissexuais e homossexuais, e no início da epidemia do HIV, foi a mais comum manifestação da aids. Contudo, na América do norte e Europa, a incidência do SK em homens com aids diminuiu significativamente após introdução da HAART (Restrepo e Ocazionez, 2011), passando de 30/1000 pacientes-ano em 1995, na era pré-HAART para 0,003/1000 pacientes-ano em 2001, na era HAART (Portsmouth et al., 2003; Restrepo e Ocazionez, 2011). Ainda assim, estudos mais atuais nos EUA apontaram que o SK ainda é 140 vezes mais frequente entre homens com HIV/aids comparado com aqueles não infectados por HIV (Seaberg et al., 2010; Chaabna-Mokrane et al., 2013). Na Europa, foi verificada a redução de 11 vezes do risco de SK, comparando antes e após a introdução de HAART (Franceschi et al., 2010). 
Outro contraste evidenciado na era pós HAART foi que PHVA (sigla de pessoas HIV que vivem com aids), embora passassem a apresentar risco diminuído de desenvolver as doenças definidoras de aids, têm sido cada vez mais propícias a desenvolver neoplasias não associadas à aids (Nguyen et al., 2010; Uldrick e Whitby, 2011). Não obstante, existem poucos estudos sobre o impacto dessas terapias no contexto dos países com recursos limitados, muitos dos quais têm elevada prevalência de coinfecção simultânea por HIV e HHV-8 (Nguyen et al., 2010; Restrepo e Ocazionez, 2011).

Embora a incidência de SK-aids tenha diminuído no mundo ocidental desde a extensiva adoção da HAART, até $50 \%$ dos pacientes com SK-aids não alcançaram a remissão total e embora tratamentos para o SK existam, nenhum é curativo. O risco de SK permanece substancialmente alto em indivíduos infectados por HIV (Nguyen et al., 2008). Por outro lado, a taxa de sobrevida para pacientes com SKaids melhorou significantemente, passando de 12,1\%(1980-1995) para 54\% (19962005), enquanto que as taxas de sobrevida para pacientes com SK clássico permaneceram estáveis durante um periodo de 30 anos, com uma pequena variação de 75,7 para $88,6 \%$. Esses dados levam a reflexão sobre o impacto trazido pelo contexto epidemiológico SK - aids em relação à possibilidade de maior dispersão de variantes de HHV-8 com potencial patogênico após a epidemia da aids, visto que o SK - aids é a forma mais agressiva e mais resistente ao tratamento do que as outras formas de SK (Strathdee et al., 1996; Tornesello et al. 2010; Armstrong et al, 2013). Além disso, há o preocupante impacto no aumento da sobrevida desses indivíduos diante das consequências das complicações crônico degenerativas geradas pelo longo tempo de infecção por HIV e da infecção latente do HHV-8.

A depeito dos relatos do declínio da incidência e gravidade do SK associado à infecção por HIV desde a introdução da terapia antirretroviral e da consequente reconstituição imune aventada (Gallafent et al., 2005; Bernstein et al, 2006, Martinez et al, 2006), tem sido demonstrado que a persistência do SK ocorre 
mesmo pós-HAART e inclusive, não se trata de um fenômeno raro, isolado ou recente (Krown et al., 2008). De forma significante, muitos pacientes com SK-aids têm células T CD4+ acima dos valores tipicamente associados à suscetibilidade à doenças oportunistas (Stebbing et al., 2008; Maurer et al., 2007). Ainda segundo esses estudos, há uma substancial proporção de pacientes com SK mesmo diante de carga viral de HIV indetectável e persistência do tumor mesmo sob doses altas de HAART. Maurer, et al., 2007 relataram em São Francisco (EUA) a persistência de SK mediante o uso de HAART em indivíduos mais velhos com longo tempo de infecção por HIV e com carga viral suprimida e aparente reconstituição imune. De forma concordante, em Cuba, a despeito do uso de HAART desde 2001, não houve declínio na incidência de SK (Kouri et al, 2012).

No Brasil, segundo dados do Ministério da Saúde, houve uma redução na manifestação do SK de $17,8 \%$ para $4,2 \%$ nos casos de aids notificados no período de 1980 a 1999 (Brasil, 2000), embora a soroprevalência do HHV8 em homens que fazem sexo com homens infectados por HIV não tenha diminuído neste período (Gao et al., 1996; Martin et al., 1998). Essa mudança temporal na proporção do SK também pode ter sido afetada pela ampliação das patologias incluídas na definição de casos de aids pelos critérios do Center for Disease Control (CDC, 1992), favorecendo a notificação de outras condições antes do aparecimento do SK. De acordo com os dados do Ministério da Saúde, o número de casos registrados de aids no período de 1980 a 2012 foi de 656.701, com uma redução de casos novos de aids na era pré HAART de 210.383 (1990-1999) para 17.819 na era HAART (Brasil, 2012). Em 2011, foram notificados 38.776 casos da doença e a taxa de incidência de aids no Brasil foi de 20,2 casos por 100 mil habitantes. Um alerta importante tem sido pontuado nos dados do Ministério da Saúde: a terapia antirretroviral aumentou a sobrevida dos portadores do HIV, resultando em um número cada vez maior de pessoas com idade mais avançada expostas à condição 
crônico-degenerativa da doença, tornando o desenvolvimento de cânceres um aspecto preocupante e que deve ser considerado nessa população (Brasil, 2012).

Estudos nos EUA têm estimativado que em 2015, mais da metade das PHVA terão mais do que 50 anos de idade. A adoção da terapia HAART reduziu drasticamente a incidência de SK-aids, aumentando a sobrevida dos pacientes. No entanto, a persistência do SK tem sido cada vez mais observada em indivíduos com longo tempo de infeção por HIV. Essa dinâmica leva a preocupante questão das consequências das doenças crônicas degenerativas nessa população com longo tempo de infecção latente viral e o impacto das doenças cancerígenas diante do esgotamento do repertório de linfócitos e da falência da resposta imune antitumoral em virtude da infecção prolongada por HIV (Biggar et al., 2004; Nguyen et al., 2010). Essa senescência imunológica prematura induzida em PHVA pode acelerar o curso de doenças cancerígenas, inclusive não associadas à aids (Derhovanessian et al., 2008; Appay et al., 2007).

\subsubsection{Suscetibilidade para o desenvolvimento do SK}

\subsubsection{Co-infecção HIV e HHV-8}

O fato de que indivíduos infectados por HIV sejam mais suscetíveis ao desenvolvimento de SK tem levado a busca da interpretação de como a co-infecção HHV-8 e HIV afeta o desenvolvimento de SK. Diferentes mecanismos têm sido discutidos, indagando-se se a proteina Tat (do inglês, Transactivative transcription) (Ensoli et al., 1990), as citocinas inflamatórias (Mercader et al., 2000) ou a se imunossupressão por si só são co-fatores importantes para o desenvolvimento de SK. De todos esses fatores, os estudos têm demonstrado que a presença da associação da infecção por HIV exerce um efeito importante sobre a conversão da 
infecção assintomática por HHV-8 em manifestações clínicas de SK evidentes. Nguyen et al. (2008) e outros autores não têm evidenciado associação entre contagem de células T CD4+ e resposta ao SK, sugerindo que a supressão da replicação do HIV, e não a reconstituição immune, possa ter um importante papel na resolução do SK (Dupin et al., 1999b; Martinez et al., 2006; Nasti et al., 2003). O apoio para tal hipótese vem de diferentes fontes: primeiro, em áreas endêmicas, o SK ocorre mesmo sem nenhuma deficiência de células T (Kestens et al., 1985). Segundo, tem-se demonstrado que o HIV induz a replicação lítica do HHV-8, e a proteína Tat do HIV aumenta a atividade de genes envolvidos na angiogênese, proliferação e replicação viral (Aoki et al., 2007).

\subsubsection{O caráter multifatorial do SK}

A soropoepidemiologia do HHV-8 indica que a exposição ao HHV-8 excede a incidência e a prevalência de SK (Biggar et al., 2000; Whitby et al, 2004; Uldrick e Whitby al., 2011); essa é mais uma razão para considerar que a fisiopatologia responsável pela origem desse processo neoplásico seja complexa e multifatorial.

É crítico o papel da imunidade na evolução de certos tumores, em especial o SK. No entanto, a relação entre o risco de câncer e o grau de imunidade parece diferir de acordo com o tipo de câncer. Há mecanismos desconhecidos ao lado da deficiência dos níveis de CD4+ que podem ter um papel na oncogênese, como sugerido por estudos que apontaram incidência diversa de certos tipos de câncer no grupo de transplantados de órgãos sólidos em comparação ao grupo de pacientes infectados por HIV (Grulich et al., 2007), embora ambos sofram igualmente uma prolongada condição de imunossupressão. A incidência de SK em receptores de transplante é de 100-500 vezes maior do que na população em geral, com significante variação entre as diferentes regiões geográficas. De fato, há um risco aumentado para o desenvolvimento do SK na imunossupressão iatrogênica, 
particularmente em pacientes transplantados renais, apesar desse aumento não ser tão grande quanto aquele observado na imunodeficiência causada pela infecção por HIV (Mesri et al., 2010).

No entanto, além do estado imunológico, são vários os fatores de susceptibilidade apontados e relacionados com a epidemiologia da distribuição do SK no mundo, como idade, sexo, etnia, predisposição genética e meio ambiente (Freitas et al., 2002; Plancoulaine et al., 2003; Newton et al., 2003; Martro et al., 2004; Souza et al., 2007b; Souza et al., 2004; Whitby et al., 2004; Whitby et al., 2007; He et al., 2007).

Embora o HHV-8 codifique genes oncogênicos que podem potencialmente induzir todos os fenótipos relacionados com SK, a infecção por HHV-8, na população em geral, raramente conduz ao SK. A infecção assintomática por HHV-8 é mais comum em localizações em que predomina o SK clássico ou endêmico (Uldrick e Whitby, 2011). Todavia, a observação da alta incidência de SK em determinados grupos e em determinadas áreas endêmicas sugerem que fatores do hospedeiro tenham um importante papel no desenvolvimento do SK. A condição da infecção por HHV-8 que culmina no desenvolvimento do SK tem sido atribuída a contribuição dos polimorfismos de genes do hospedeiro, embora esses trabalhos ainda tenham apontado discretas associações. Estudos têm mostrado que a variabilidade dos alelos de HLA, particularmente os que codificam HLA-DR, pode influenciar a resposta à infecções, inclusive com a identificação de possíveis marcadores de suscetibilidade para o desenvolvimento do SK (Gaya, 2004). Alguns estudos que exploraram a potencial contribuição de polimorfismos de genes responsáveis por resposta inflamatória do hospedeiro, apontaram que o risco de SK clássico foi associado com diplótipos de receptores de beta-IL-8 (IL8RB), IL-13 e certos haplótipos de Antígenos de Histocompatibilidade de Linfócitos (HLA) (Brown et al., 2006; Masala et al., 2005; Dorak et al., 2005). Outrossim, autores apontaram maior risco de SK em transplantados, associando tal risco a polimorfismos no promotor de 
IL-6 (Bhagwat et al., 1980) e maior risco de SK em infectados por HIV com genótipos FcyRIIIA (Lehrnbecher et al., 2000).

\subsection{Herpesvírus 8 humano}

A partir da descoberta do HHV-8 como o agente etiológico do SK, importantes informações para a caracterização desse vírus oncogênico foram reunidas, conforme as descrições de soroepidemiologia, taxonomia, estrutura genômica e variabilidade genética apresentadas a seguir.

\subsubsection{Epidemiologia da infecção por HHV-8 e vias de transmissão no mundo e no Brasil}

\subsubsection{Estudos de soroprevalência do HHV-8 no mundo e no Brasil}

O desenvolvimento de estudos soroepidemiológicos foram abrangentes e capazes de evidenciar mais claramente a distrubuição não ubíqua do HHV-8 baseados em ensaios de imunofluorescência ou IFA (sigla do inglês, Imunofluorescence Assay) e ELISA (sigla do inglês, Enzyme Linked Immunosorbent Assay). A mais baixa soroprevalência de HHV-8 (<10\%) tem sido observada no norte da Europa, Ásia e América do Norte; uma soroprevalência intermediária (20$30 \%$ ) tem sido observada no mediterrâneo, leste da Europa e países do Caribe; alta prevalência $(>50 \%)$ tem sido apontada na Africa Central e do sul (Moore et al., 2000; Lagos e Boshoff, 2007; Uldrick e Whitby, 2011). A Figura 1 apresenta a distribuição diferencial do HHV-8 baseada em estudos soroepidemiológicos. 




Figura 1 - A diferencial distribuição do HHV-8 baseada em estudos soroepidemiológicos (Adaptado de Lagos e Boshoff, 2007)

No Brasil, o perfil de distribuição de infecção por HHV-8 na população geral é baixo e segue os padrões semelhantes aos registrados na Europa e EUA. De forma contrastante, o HHV-8 é hiperendêmico em algumas tribos de ameríndios da Amazônia brasileira (Biggar et al., 2000; Souza et al., 2007b; Ishak et al., 2007; Souza et al., 2010; Borges el al., 2012). Há ainda significativa soroprevalência do HHV8 na população infectada por HIV numa variação de 15\% a 39,2\% (Zhang et al., 1998, Caterino-de Araújo et al., 1999; Pierrotti et al., 2000; Zago et al., 2000; Keller et al., 2001; Souza et al., 2004).

A exemplo da Europa e EUA, a prevalência de anticorpos anti-HHV-8 no Brasil apresenta importantes diferenças de acordo com a população estudada, conforme observado nas avaliações para pesquisa de anticorpos dirigidos à antígenos da fase latente (LANA ou Latence Nuclear Antigen) ou lítica do HHIV-8, nos estudos de algumas regiões brasileiras.

Assim, Zhang et al. (1998) apontaram a presença de 64\% (9/14) de soropositivos na IFA para LANA/HHV-8 em homossexuais HIV-positvo/KS-positivo. No entanto, em um grupo de doadores de sangue, Caterino-de-Araujo (1999) 
determinaram a soroprevalência de HHV-8 por IFA para HHV-8/LANA e encontraram $7,4 \%$ de soropositivos.

Biggar et al., 2000 num estudo 781 Ameríndios usando a mesma metodologia demostraram que a prevalência de HHV-8 foi em torno de $53 \%$ em várias tribos da amazônia, sendo $41 \%$ em crianças com < 10 anos de idade e $65 \%$ em adultos com $\geq 30$ anos de idade, independente do isolamento cultural (linguagem) ou sexo. Foi detectado DNA/HHV-8 em três (16\%) das 19 amostras de CMSP (células mononucleares do sangue periférico) de indivíduos soropositivos por IFA/HHV-8.

Segundo Pierrotti et al. (2000), em pacientes infectados por HIV em uma unidade de Saúde de São Paulo, a prevalência do HHV-8 foi significativamente maior entre homossexuais $(37,7 \%)$ e bissexuais $(28,6 \%)$ em relação aos heterossexuais $(11,8 \%)$ e usuários de drogas injetáveis $(8,0 \%)$.

Zago et al. (2000) relataram que anticorpos anti-HHV-8 foram detectados em baixa frequência em doadores de sangue (4,6\%). No grupo HIV-negativo atendidos na Clínica de DST/aids, somente $3,7 \%$ dos pacientes tinham anticorpos anti-HHV-8 e, ao contrário, a alta frequência de positividade para anticorpos anti-HHV-8 foi observada no grupo HIV-positivo/KS-positivo (80\%) enquanto no grupo HIV-positivo/KS-negativo foi de $14,6 \%$, todos analisados por IFA para detecção de anticorpos anti-HHV-8/LANA

Freitas et al. (2002) relataram a seroprevalência na população de habitantes de duas cidades vizinhas do norte do Brasil através da detecção de anticorpos IgG anti-HHV-8 por uso do teste comercial ELISA. Em geral, 16,3\% (81/497) das pessoas testadas tinham anticorpos anti-HHV-8, variando de 12 a 33,3\% de acordo com o grupo etário. Similar taxa de prevalência foi obtida em mulheres e homens (18,4\% e $14 \%$, respectivamente).

Caterino-de-Araujo et al. (2003) relataram a seroprevalência em crianças e mulheres de São Paulo. O primeiro grupo constituído de 163 mulheres infectadas por HIV apresentaram frequência geral de soropositividade de 8,6\%, sendo 1,2\% 
de positividade para anticorpos anti-LANA e $8 \%$ para anti-anticorpos anti-lítico. O segundo grupo, constituído por 108 crianças nascidas de mães HIV-positivas; apresentou soropositividade de 7,4\%. Dentre estas crianças, soropositividade de $10,9 \%$ foi detectada nas crianças HIV-positivas e $8,3 \%$ nas crianças com status de HIV não definido. O terceiro grupo foi de 630 mulheres sadias HIV-negativas; elas apresentaram soropositividade em torno de $1,3 \%$, de anticopos anti-LANA e de 0,3\% de anticorpos anti-lítico.

Souza et al. (2004) estudaram a soropositividade para HHV-8 em crianças e adultos sadios em 10 cidades de São Paulo $(n=643)$, detectando soroprevalência de $2,5 \%$ por IFA/Lítico e nenhum caso de positividade para IFA/LANA. Em homossexuais HIV-negativos foi detectada soropositividade de $32,6 \%$, em indivíduos HIV-positivo/SK-negativo de 39,2\%; e em indivíduos HIV-positivo/KSpositivo de $98,7 \%$.

Nascimento et al. (2007) compararam várias técnicas comerciais e in house, confirmaram os dados dos trabalhos anteriores e ainda obtiveram soroprevalência em torno de $47,4 \%$ em HSH sem SK e não infectados por HIV através do ELISA com antígeno celular bruto, e entre 10,6 a $12,8 \%$ para pesquisa de anticorpos antiHHV-8 contra antígenos latente e lítico na IFA, respectivamente,

\subsubsection{Vias de transmissão do HHV-8}

A transmissão do HHV-8 não é bem clara. A epidemiologia do SK-aids tem apontado desde o início da epidemia do HIV que a transmissão por HHV-8 ocorre preferencialmente por contato sexual, particularmente entre homens que fazem sexo com homens $(\mathrm{HSH})$, numa taxa 100.000 vezes maior do que na população em geral (Biggar, et al, 1996). Os estudos inicias de epidemia da aids já apontavam a maior prevalência de anticorpos anti-HHV-8 entre HSH do que usuários de drogas e 
hemofílicos infectados por HIV (Kedes et al., 1996). E ainda revelaram a associação entre o número de parceiros sexuais e desenvolvimento de SK (Beral et al., 1990; Martin et al., 1998; Blackbourn et al., 1998).

No entanto, apesar das indicações de que a via sexual ocorra, outras vias de transmissão de HHV-8 diferentes parecem segregar ou coexistir em grupos populacionais particulares.

A descoberta de Chang et al (1994) abriu amplas possibilidades de estudo da prevalência do HHV-8 baseada na detecção do DNA do HHV-8 por PCR em biópsia de tecido (Boshoff et al., 1995; Dupin et al., 1995; Chang et al., 1996), em células mononucleares do sangue periférico (CMSP) (Moore et al., 1996b; Ishak et al, 2007) e na saliva (Blackbourn et al., 1998; Souza et al., 2007b; de França et al., 2011; Del Mistro et al., 2012). Atualmente, a maioria dos estudos concordam que virions e DNA de HHV-8 em altos níveis podem estar presentes na saliva de pacientes infectados por HIV (Lebbe et al., 2008; Kouri et al., 2010; Souza et al., 2010; Mancuso et al, 2011) e que a saliva desses indivíduos, com ou sem lesões de SK, é uma fonte de infecção para HHV-8 (Koelle et al, 1997; Blackbourn et al, 1998; Zong et al, 2007; Lebbe et al., 2008). Alguns autores tem apontado, ao contrário do esperado, uma maior taxa de detecção de DNA de HHV-8 na saliva associada à contagem de células T CD4+ (> 350 células $/ \mathrm{mm}^{3}$ e estável) em indivíduos infectados por HIV (Gandhi et al., 2004), igualmente para a taxa de DNA de HHV-8 no plasma (Tedeschi et al., 2001), de modo a representar uma maior chance de transmissão do HHV-8 nessa condição.

Outrossim, em regiões endêmicas, como na África e entre ameríndios, os estudos soroepidemiológicos mostraram que a infecção por HHV-8 ocorre também na infância e aumenta com a idade, consistente com a indicação de transmissão viral horizontal não sexual (Andreoni et al, 1999; Olsen et al, 1998; Souza et al, 2007b). Existem também evidências consistentes de transmissão do HHV-8 da mãe para filho através de saliva (Plancoulaine et al., 2000; Dedicoat et al., 2004; Borges et et al., 2012). 
Além das indicações epidemiológicas, a associação da saliva na transmissão do HHV-8 está também fundamentada em estudos que demonstraram a replicação do HHV-8 nas células do epitélio oral. O primeiro estudo de infectividade da saliva foi demonstrada por Vieira et al. (1997), que demonstraram a viabilidade do HHV-8 em amostras de saliva inoculadas em cultura de células após treze passagens. Posteriormente, Duus et al. (2004) demonstraram que células epiteliais do trato oral são suscetíveis à infecção por HHV-8 e que o epitélio oral pode ser, de fato, um reservatório do HHV-8, assim como ocorre com os outros herpesvírus orais.

Vários trabalhos demonstraram a presença do DNA do HHV-8 na cavidade oral pela técnica de PCR em pacientes infectados por HIV ou não, em taxas de positividade que variaram entre indivíduos com SK (15 a 71\%) e sem SK (15 a 61\%) (Di Alberti et al, 1997; Koelle et al, 1997; Blackbourn et al, 1998; Lampinen et al, 2000; Pauk et al, 2000; Triantos et al, 2004; Cannon et al., 2003; Casper et al, 2004).

Foi também observado que o DNA do HHV8 foi mais frequentemente encontrado em mais altas concentrações no fluído oral do que em células mononucleares do sangue periférico e no plasma, e ainda menos frequentemente no sémen, secreções prostáticas, uretrais e em swab anal de HSH com ou sem HIV. LaDuca et al. (1998) quantificaram DNA de HHV-8 em diferentes amostras clínicas de indivíduos com SK e observaram alto número de cópias de DNA na saliva (33.000 cópias $/ \mu \mathrm{g}$ ) de $37 \%$ dos casos, comparado ao encontrado em células mononucleares do sangue periférico (9.000 cópias/ $\mu \mathrm{g}$ ) de $46 \%$ dos casos, no

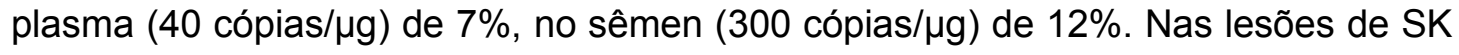

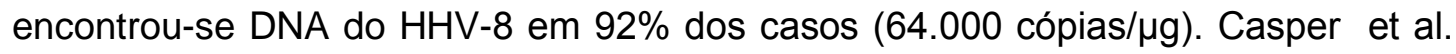
(2007) apontaram alta taxa de excreção intermitente de HHV-8 na saliva (61\%) em HSH não infectados pelo HIV e sem SK.

Em contraste com a maioria dos estudos que não relataram infecção por HHV-8 em controles sadios, Miller et al. (2006) encontraram $24 \%$ de positividade na saliva em voluntários adultos HIV-negativo e KS-negativo do campus universitário de 
Kentucky (EUA), região em que a prevalência de anticorpos anti-HHV-8 na população geral é baixa. Se confirmado, esse estudo sugere que haja mais casos de infeções assintomáticas do que se tem demonstrado.

Embora, não haja nenhum comportamento sexual particular que seja claramente identificado como o de maior risco de transmissão do HHV-8, a presença de DNA HHV-8 mais comumente observada na cavidade oral passa a sustentar a hipótese de que a prática sexual que leva a transferência de fluídos orais possa representar uma importante via de transmissão (Martin et al., 1998; Martin et al., 2000).

Os estudos são igualmemte consistentes em apontar que a infecção por HHV-8 é frequentemente encontrada na orofaringe de pacientes com SK (Vieira et al., 1997; Blackbourn et al., 1998), conforme descrito em habitantes de regiões em que predomina o SK clássico e no contexto intrafamiliar em que um membro da família é acometido por SK (Mancuso et al, 2011; Guttman-Yassky et al., 2004). Ainda nesse contexto, as cargas virais de HHV-8 parecem ser usualmente mais altas na saliva do que em amostras de sangue (Mbulaiteye et al., 2004).

No contexto endêmico do SK, entre ameríndios e certas regiões africanas, há significativa proporção de crianças infectadas por HHV-8, apontando a saliva como via de transmissão de mãe para filho e entre irmãos durante a infância (Biggar et al., 2000; Dedicoat et al., 2004; Mbulaiteye et al., 2006; Souza et al., 2007b), e essa evidencia foi correlacionada com a presença de anticorpos contra antígeno de fase latente do vírus (Borges et al., 2012).

Estudos têm sugerido que haja diferentes modalidades de transmissão presentes em áreas de baixa prevalência, como certas regiões da Europa e EUA e alta prevalência , como na África subsaariana. Assim, em áreas não endêmicas ou de baixa endemicidade, o HHV-8 predomina no contexto SK-aids em HSH, sendo sugerido o contato sexual. Em áreas de alta endemicidade, a principal modalidade de transmissão parece ser atráves da contato mãe-filho e entre irmãos e de pessoa a pessoa (Vitale et al., 2000; Dedicoat et al., 2004; Souza et al., 2007b; Borges et al., 2012). 
Embora o HHV-8 seja detectado em linfócitos circulantes em torno de 15 $50 \%$ dos pacientes com SK (Whitby, et al., 1995; Pierrotti et al., 2000), a transmissão via sanguínea do HHV-8 não foi ainda consistentemente comprovada, visto que muitos estudos falharam em detectar DNA/HHV-8 em doadores de sangue que foram soropositivos para HHV-8 em regiões não endêmicas, como Estados Unidos e São Paulo (Beral et al., 1990; Pellet, et al., 2003; Cannon et al., 2009; Levi et al., 2011). A transmissão do HHV-8 por transfusão sanguínea parece comum em áreas de alta prevalência de HHV-8 (Beléc et al., 1998; Hladik et al., 2006; Hladik et al., 2012), e parece ser incomun em áreas de baixa prevalência de SK (Cannon et al, 2009; Levi et al., 2011). Ainda que o risco seja muito diferente em áreas endêmicas e não endêmicas, a presença de HHV-8 no sangue de doadores tem sido documentada em indivíduos soropositivos para HHV-8 de áreas endêmicas ou não (Dollard et al., 2005; Hladik et al., 2012).

Esses trabalhos têm apresentado significativos exemplos de que o HHV-8, ao contrário dos outros herpesvírus, parece ser indetectável na população em geral, e por outro lado, vias de transmissão de HHV-8 diferentes parecem segregar ou coexistir em grupos populacionais particulares, e ainda associados a quadros graves indolentes ou assintomáticos.

\subsubsection{Classificação do HHV-8}

A classificação inicialmente proposta para os Herpesvirus foi criada pelo Grupo de Estudos Herpesvírus do Comitê Internacional de Taxonomia de Vírus baseada em suas propriedades biológicas. Mais tarde, no entanto, os estudos moleculares foram capazes de identificar e caracterizar adequadamente as subfamílias virais baseando-se em estudos de similaridades de sequencias e análise de genomas (Pellet e Roizman, 2007). 
Mais de 130 herpesvírus foram descobertos até o momento, todos constituídos de DNA dupla fita que podem estabelecer infecções latentes em seus respectivos hospedeiros vertebrados; entretando, somente oito deles regularmente estabelecem infecção em humanos. O herpesvírus humano tipo 8 (HHV-8) é um dos oito membros da família Herpesviridae que infecta o homem.

HHV-8 pertence ao gênero Rhadnovirus, da subfamília Gammaherpesvirinae ( -herpesvirinae), que também inclui o Epstein Barr vírus ou HHV-4. Outras duas subfamílas dos herpesvírus são: subfamília Alphaherpesvirinae (a-herpesvirinae), que inclui o herpesvirus 1 (HVS-1) e 2 (HVS-2), e ainda o vírus varicela/zoster (HHV-3), e a subfamília Betaherpesvirinae ( $\beta$-herpesvirinae), que inclui os HHV-5 ou Citomegalovírus, HHV-6 e HHV-7 (Moore et al, 1996b).

A subfamília Gamaherpesvirinae contém dois gêneros que incluem os gamma-1 ou ymprhocryptovirus (LCV) e o gamma-2 ou Rhadnovirus (RDV). O EBV é o único LCV e o HHV-8 é o único RDV até o momento descobertos que são capazes de infectar o homem. O DNA do HHV-8 apresenta similaridade maior com membros da subfamília Gammaherpesvirinae que não causam doença em humanos, do que com o EBV, agente da mononucleose infecciosa e associado ao linfoma de Burkit e a outras formas de câncer em humanos (Edelman, 2005). O HHV-8 tem proximidade evolutiva ao Herpesvirus saimiri (HSV), também do gênero Rhadnovirus o qual pode causar linfoma fulminante de células $T$ em seus hospedeiros primatas e pode imortalizar linfócitos T infectados (Moore e Chang, 2001). A Figura 2 mostra a relação filogenética dos herpesvirus. 


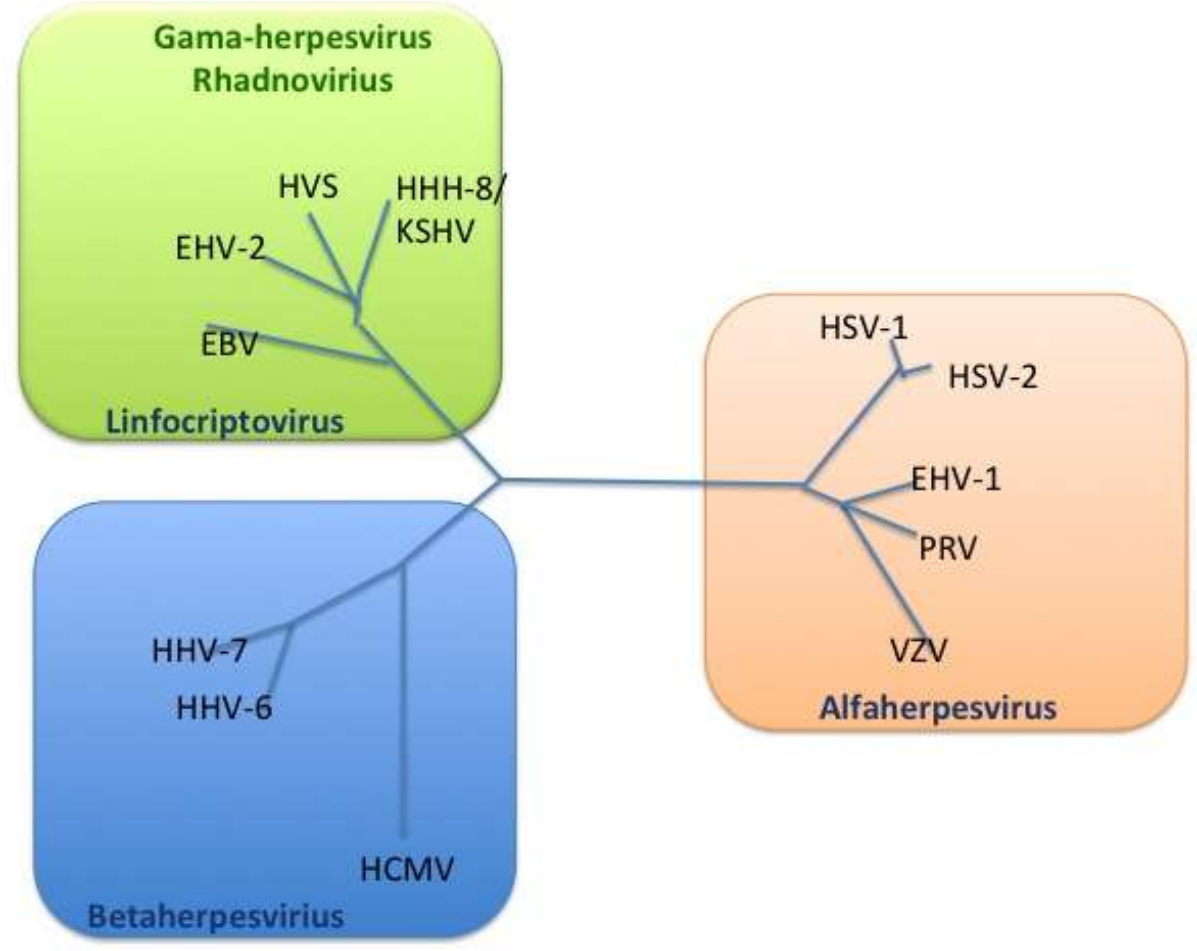

Figura 2 - Árvore filogenética dos herpesvírus. Herpesvírus 8 humano (HHV-8) ou herpesvírus associado ao sarcoma de Kaposi (KSHV), é um membro da subfamília Gamaherpesvirinae, gênero Rhadinovírus. EBV, vírus Epstein Barr; EHV-2, herpesvírus equino tipo 2; HVS, herpesvírus saimiri; HSV1, herpesvírus simples tipo1; HSV-2, herpesvírus simples tipo 2; EHV-1, herpesvírus eqüino tipo 1; PRV, vírus pseudo- rábico; VZV, vírus da varicela-zoster; HCMV, citomegalovírus humano; HHV-6, herpesvirus 6 humano e HHV-7, herpesvírus 7 humano. Modificado de Moore et al.,1996b; Ganem et al, 2010)

\subsubsection{Estrutura do Genoma do HHV-8}

O HHV-8 é constituído de dupla fitas DNA de 124 - $230 \mathrm{~Kb}$ compactadas em um capsídeo ecosaédrico (cerca de $125 \mathrm{~nm}$ em diâmetro). O conjunto de genes do HHV-8 tem sido avaliado desde a descoberta formal do HHV-8 (Russo et al., 1996; Rezaee et al, 2006). A região das ORFs (do inglês, Open Reading Frame) ocupa 138-140,5 kb em comprimento no genoma, e as extremidades da sequência apresentam regiões denominadas TR (Terminal Repeats) que são unidades repetitivas que variam de $16-75 \mathrm{~Kb}$, gerando variações no tamanho do genoma 
(Wen e Damania, 2010). A Figura 3, a seguir, apresenta a estrutura da sequência completa do genoma do HHV-8 e destaca os genes exclusivos do HHV-8 (K1-K15).
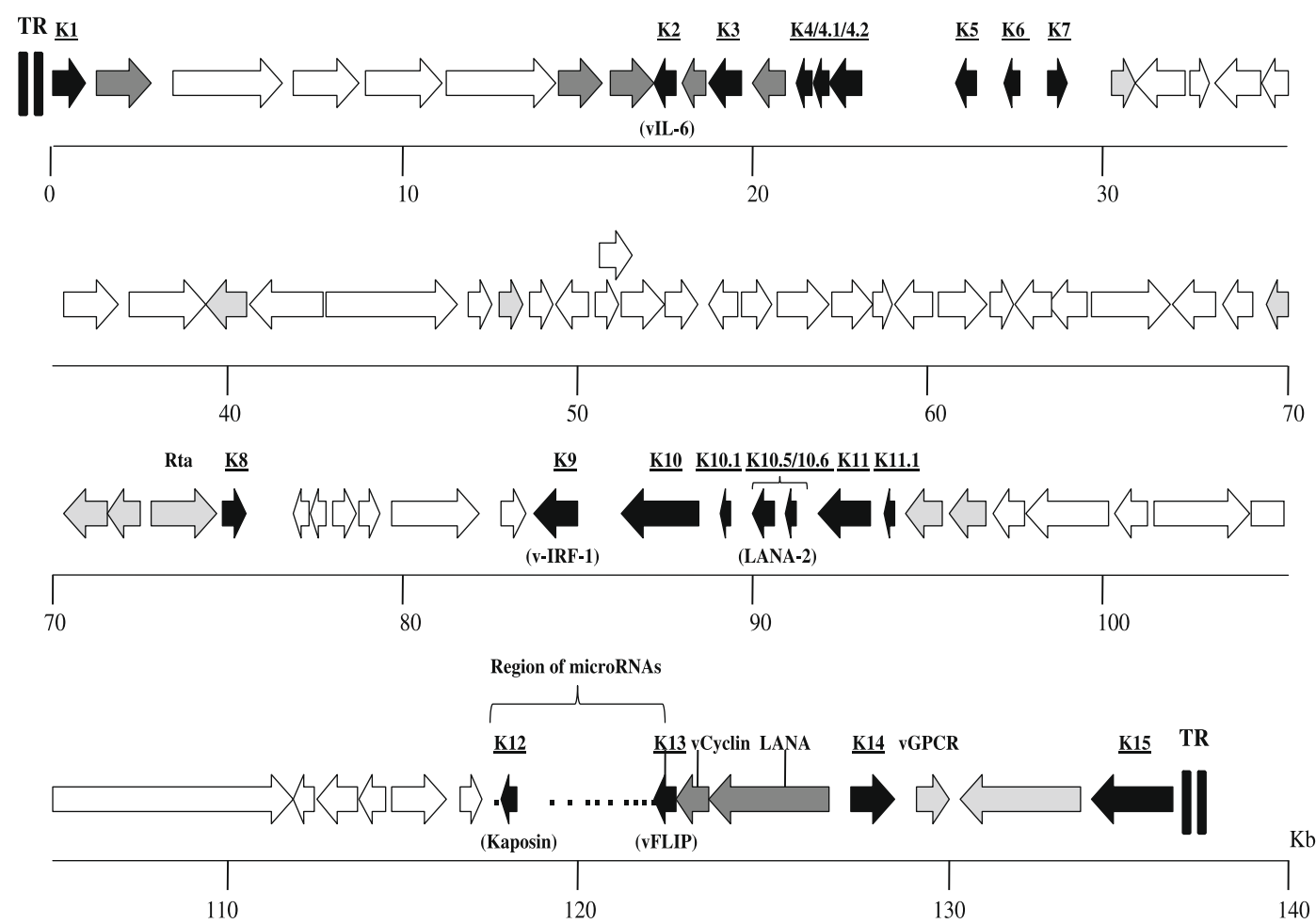

Figura 3 - Mapa de genes do HHV-8. Esquemas da disposição das unidades de ORFs do genoma do HHV-8 indicadas por setas e o microRNA codificado pelo HHV-8 em pontilhado. As ORFs exclusivas ao genoma do HHV-8 (K1-K15) foram representadas por setas pretas. As ORFs comuns a outros Rhadnovírus e comuns a outros gamma-herpesvírus (exemplo, EBV) foram representadas por setas de cor cinza escura e cinza clara, respectivamente. As regiões ocupadas por setas de cor branca representam a disposição das ORFs comuns a maioria dos herpesvírus. Os números marcados linearmente ao longo do genoma indicam a posição aproximada no genoma em kilobases (Kb); TR - unidades repetitivas terminais flanqueando o genoma (Wen e Damania, 2010).

O genoma do HHV-8 foi sequenciado e analisado na sua forma epissomal extracromossômica. O genoma do HHV-8 é dividido em blocos de genes estruturais altamente conservados e semelhantes aos genes estruturais encontrados em outros herpesvírus. A porção central do genoma é flanqueada por genes que têm pouca ou nenhuma similaridade com outros herpesvírus. O genoma apresenta uma região de cadeia longa codificante (LUR- long unique region) altamente conservada, contendo 
baixas concentrações de $\mathrm{G}+\mathrm{C}$ (53,5 \%). Nessa região, denominada "L ADN", encontram-se as ORFs. Em ambas as extremidades da "L ADN" estão localizadas as regiões terminais (TR), contendo sítios reguladores com altas concentrações de G+C (84 \%) e denominadas "H ADN" (Russo et al., 1996; Wen e Damania, 2010). As ORFs homólogas ao HVS (Herpesvirus saimiri) são enumeradas de 1 a 75 e as outras quinze ORFs identificadas no genoma do HHV-8, que são únicas desse herpesvírus, são designadas com o prefixo K (K1 a K15) e outras designadas com valores decimais ligados ao prefixo K (K4.1, K4.2, K8.1 e K10) (Russo et al.,1996; Jenner e Boshoff, 2002). Algumas ORFs são homólogas aos genes celulares humanos (Moore e Chang, 2001; Rezaee et al., 2006).

\subsubsection{Programas transcricionais do HHV-8: fase latente e fase lítica.}

Assim como os demais membros da família dos herpesvirus, o HHV-8 pode expressar seus genes por dois programas transcricionais: o primeiro deles é a latência. Na latência, a forma circular epissomal resultante da integração nuclear do vírus é mantida de forma autônoma, com moderada produção de cópias. A latência representa uma estratégia passiva, quando um número mínimo de produtos gênicos é expresso e consequentemente, um número restrito de antígenos é apresentado ao sistema imune para evocar resposta imune citotóxica (Ganem et al., 2010). Foi descoberto que HHV-8 expressa 12 pré-microRNAs (miRNA) durante a latência, que regulam a expressão pós-transcricional de genes, de modo a representar um caminho para modular a expressão de genes do hospedeiro sem adicional produção de proteínas virais antigênicas (Cai et al., 2005; Pfeffer et al.,2005; Samols et al., 2005; Grundhoff et al., 2006; Gottwein et al., 2012 ).

Em linhagens de células estabelecidas em cultura, a infecção latente que se segue não expõe nenhum fenótipo evidente do HHV-8. A maioria das spindle cells é latentemente infectada na forma tumoral avançada de sarcoma de Kaposi e a 
minoria das células infectadas expressa marcadores líticos (Renne et al., 1996; Lagunoff et al., 1997; Ganem, 2010).

Os locus da latência possue três genes de latência ou ORFs, que codificam proteínas associadas à latência: ciclina viral (v-cyclin), vFLIP (viral Flice-inhibitory protein) e kaposinas A, B e C. Muitas das informações existentes hoje sobre as proteínas de latência estão relacionadas à LANA (Latency-Associated Nuclear Antigen) (Ballestas et al, 1999; Ballestas et al., 2001; Cotter et al., 1999; Cotter et., 2001; Garber, 2001; Garber et al., 2002; Barbera et al., 2006; Viejo-Borbolla et al.,2005). A reativação espontânea da latência ocorre regularmente, em células em cultivo (Renne et al., 1996) e in vivo (Pauk et al., 2000; Vieira et al., 2004; Casper et al., 2007), visto que a latência não é irreversível.

O segundo programa de expressão gênica viral é a replicação lítica. Nesse programa, a expressão de todos os genes é virtualmente ativada em cascata; a progênie viral é produzida e as células infectadas morrem (Renne et al.,1996; Miller et al.,1996; Ganem, 2010). Durante a fase lítica, o genoma do HHV-8 é linear e o genoma viral inteiro é expresso e as proteínas virais resultantes são susceptíveis a interferência da vigilância imunológica, cuja pressão induz o vírus a adotar estratégias de evasão.

No hospedeiro humano, o principal sítio de replicação lítica é a orofaringe, provavelmente nas células $B$ tonsilares, tecidos linfóides da faringe, inclusive 0 epitélio da orofaringe (Duus et al., 2004). Estudos clínicos mostraram que a excreção de virions de HHV-8 ocorre em surtos periódicos e reflete a intermitência da reativação lítica, sendo geralmente assintomática (Pauk et al., 2000; Casper et al., 2007). Essa propriedade biológica viral reflete muito da epidemiologia do HHV-8, que presumivelmente parece ser condicionada à exposição da mucosa ao vírus pela saliva, tanto na transmissão sexual entre adultos (Martin et al., 1998) quanto na dispersão horizontal do vírus entre crianças pré-púberes nas zonas endêmicas da África, entre Ameríndios da Amazônia e na bacia do Mediterrâneo (Schulz, 1999). 
A expressão dos genes de fase lítica do HHV-8 gera produtos proangiogênicos e proinflamatórios que parecem fornecer um microambiente favorável à proliferação da célula hospedeira, persistência viral e secundariamente, induzindo respostas inflamatórias que desempenham papel importante na patogênese do SK (Grundhoff e Ganem, 2004).

Ganem (2010) levanta a hipótese de que a replicação lítica do HHV-8 é continuamente necessária em toda a longa história natural da infecção para desenvolvimento do SK. Muitos trabalhos ressaltaram a importância do ciclo lítico na tumorigenese e descreveram genes do ciclo lítico do vírus que codificam várias proteínas secretadas que são moléculas de sinalização, algumas das quais são claramente pró-inflamatórias. O programa lítico também inclue várias proteínas transmembranas sinalizadoras que podem induzir a expressão de genes do hospedeiro com potencial proinflamatório e proangiogênico. O resultado é a ativação de um amplo programa de expressão de citocinas e quimiocinas durante a replicação litica (Brinkmann et al., 2007; Konrad et al., 2009).

\subsubsection{Propriedades biológicas decifradas no genoma do HHV-8}

A descoberta de novos mecanismos de oncogênese segue à medida que mais informações são apontadas na estrutura do genoma do HHV-8 e das suas ORFs individualmente (Russo et al., 1996). O genoma viral é constituído por muitos genes e ainda regiões restritas codificadoras de microRNA com homologia celular, os quais estão envolvidos em mecanismos que permitem ao vírus promover a transformação celular, assim como modulação de citocinas e de receptores de citocinas, regulação do ciclo celular e da inibição da apoptose, regulação da cascata de complemento e do processo de controle do contato célula a célula (Moore et al., 1996c, Rezaee et al, 2006, Ramalingam et al.,2012). 
As ORFs de HHV-8 com homologia celular foram incorporadas ao genoma viral em resposta a pressão evolucionária durante ativação de seus programas transcricionais para a produção da progênie viral e/ou latência no interior de seu hospedeiro (Alcami et al, 2003; Grundhoff e Ganem, 2004; Rezaee et al, 2006).

Os genes virais foram denominados com a sigla do nome dos genes celulares para os quais eles têm homologia, ou precedida da letra minúscula "v" ou com a denominação das proteínas ou das ORFs que as codificam. Esse fenômeno de incorporação viral de genes do hospedeiro tem sido comumente descrito como pirataria molecular. Vários exemplos dessa estratégia foram decifrados no genoma do HHV-8. A vCyc-D (viral Cyclin D), transcrito latente da ORF 72, compartilha 53\% de homologia com ciclina D2 celular ( $\mathrm{Li}$ et al., 1997) e tem a capacidade de inativar proteína supressora de tumor, aumentando a probabilidade de desenvolvimento de neoplasias [Moore et al., 1996c; Murphy et al., 1997)]. Outrossim, a ORF 16 codifica a vBcl-2 (viral B-cell lymphoma-2), proteína do ciclo lítico do HHV-8 que compartilha 15 a 20\% de homologia com a Bcl-2 celular, com função relacionada à inibição da apoptose (Russo et al., 1996). Outro gene viral com homologia celular que resulta na inibição da apoptose é a ORF 71, que codifica a vFLIP (FLICE Inibitory Protein), com atividade antiapoptótica intermediada pela inibição de Caspase-8 (Djerbi et al., 1999, Thome et al., 1997).

Algumas ORFs codificam estratégias que são chave da patogênese do SK como a vIL-6 (viral Interleucin-6) e a vMIP (viral Macrophage Inflammatory Protein). A vIL_6 é codificada pela ORF K2, a vMIP-1 é codificada pela ORF K6 e a vMIP-2 pela ORF K4. Estudos mais atuais apontaram que vMIP são quimiocinas, portanto são agora denominadas vCCL ou (viral chemokine $C$ - $C$ motif). As denominações atuais sinônimas são: ORF K6 (vMIP-1, vMIP1a, vCCL-1), ORF K4 (vMIP-2, vMIP-1b, vCCL-2) e K4.1 (vMIP-3, vBCK, vCCL-3). Essas proteínas do ciclo lítico, vMIPs ou vCCLs, são altamente angiogênicas e imunorregulatórias, favorecem a evasão da reposta imune dos linfócitos $\mathrm{T}$ citotóxicos, recrutam leucócitos ao sítio inflamatório e promovem a angiohiperplasia (Damania, 2004), Nicholas et al., 2005, Jenner et al., 2001). Outro 
homólogo com atividade de quimiocinas é a proteína expressa no ciclo lítico do HHV-8, denominada vGPCR (viral G Protein Coupled Receptor), codificado pela ORF 74, que compartilha homologia com fatores de quimiocinas, receptor de IL-8 e proteínas transmembrana (Russo et al., 1996), sendo relacionada com vias de quinase ativadas por mitógenos que imortalizam células endoteliais. O trascrito da ORF 74 tem sido relatado como um fator importante no crescimento e diferenciação celular promovendo a transformação maligna (Arvanitakis et al., 1997; Bais et al., 1998; Bais et al., 2003).

Tem-se demonstrado que a proteina LANA-1 codificada pela ORF 73 (Friborg et al., 1999) e vIRF (viral Interferon Regulador Factor) codificado pela ORF K9 (Nakamura et al., 2001) reprimem a transcrição da p53 e sua capacidade de induzir a apoptose, e dessa forma promovem o crescimento e transformação celular.

O HHV-8 tem o controle multifuncional de citocinas do hospedeiro incorporado em seu genoma, isto é, tem genes vIRF com homologia a IRF celular (Neipel et al., 1997; Taniguchi e Takaoka, 2002; Kirchhoff et al., 2002; Rezaee et al., 2006). A vIRF-1 (ORF K9) tem sido apontada como transcrito do ciclo lítico e detectável em biópsia da doença multicêntrica de Castleman e no sarcoma de Kaposi (Moore et al., 1996c). A vIRF-2 (da ORF K11.1) e a vIRF-3 (da ORF 10.5 e K10.6), ambas também têm ação antiapoptótica, por mecanismos diferentes, quer seja através ligação com fatores transcricionais como NF-kB (Nuclear factor kappaB) ou através do bloqueio de outros fatores de transcrição de genes codificadores de citocinas, que atuam na ativação de células da resposta imune antiviral.

Outras ORFs codificam proteínas que fazem parte da estrutura celular, um exemplo de proteína trasmembrana representativa do ciclo lítico do HHV-8 é a proteína codificada pela ORF K15, com 12 domínios transmembrana. A K15 interage com proteínas celulares e induz a expressão de múltiplas citocinas (Brinkmann et al., 2007). Tem-se descrito o seu papel de diminuir a regulação de citocinas inflamatórias do hospedeiro. A cauda citoplasmática pode ser submetida à fosforilação da tirosina, que conduz ao recrutamento TRAF3 (TNF receptor-associated factor 3), um membro 
da família dos receptores de TNF e ativação do fator de transcrição NF-kB (Konrad et al., 2009; Ganem, 2010).

A RTA (Regulation Transcriptional activator), uma proteína associada ao tegumento do virion e codificada pela ORF 45, bloqueia a fosforilação de proteínas celulares, inibe IRF celulares e induz ao bloqueio de fatores supressores do tumor (Rezaee et al., 2006). A RTA inibe a ativação de interferons tipo 1 e seus genes durante a infecção viral. Além disso, RTA é componente fundamental para dirigir a resposta de INF, especialmente por meio da IRF-7, que é o pivô da orquestração da produção de INF (Honda et al., 2005; Zhu et al., 2002). RTA completa a função das IRFs, as quais são multifuncionais, envolvidas na regulação do ciclo celular, da apoptose e da supressão ou promoção do tumor (Taniguchi e Takaoka., 2002; Rezaee, et al., 2006).

O reconhecimento célula a célula ou a apresentação de antígenos por células do sistema imune do hospedeiro é um mecanismo sob controle viral igualmente mimetizado pelo HHV-8 por meio das ORFs K3 e K5 (Russo et al, 1996), as quais são reconhecidas como codificadoras de MIR-1 e MIR-2 (Modulator of Immune Recognition), respectivamente. São proteínas do ciclo lítico do HHV-8 pertencentes a família das enzimas ubiquitinas E3 ligases (Rezaee et al., 2006). A ORF K3 codifica uma proteína que acelera a endocitose do complexo maior de histocompatibilidade (MHC) classe I, prevenindo a apresentação de antígenos virais especialmente aos linfócitos T citotóxicos (Manes et al., 2010). De forma similar, os fatores reguladores de interferon (IRFs) anteriormente citados, também interferem no contato célula a célula, atuando na resposta imune antiviral inata ou adaptativa e inibindo a expressão ou a atividade do interferon-gama celular e reduzindo a expressão de MHC classe I e II e outras moléculas co-estimulatorias (Rezaee et al., 2006, Manes et al., 2010).

A interferência viral na ativação da cascata de proteínas da via do sistema complemento é representada pela atividade do produto da ORF 4 da KCP (KSHV complement control protein), que compartilha homologia com proteínas celulares reguladoras do sistema complemento. Por Splicing alternativo o gene KCP codifica pelo 
menos três isoformas que desencadeiam o bloqueio da lise de células infectadas por vírus através de inibição da formação de cascata enzimática de ataque a membrana celular ou da superfície viral (Spiller et al., 2003; Rezaee et al., 2006).

A proteína vOX2 codificada pela ORF K14 é expressa durante o ciclo lítico e apresenta $36 \%$ de homologia com a OX2 humana $\left(\mathrm{CD}_{200}\right)$, um membro da família das imunoglobulinas. Age no receptor de $C_{200}\left(C_{200} R\right)$, o qual tem expressão restrita em células mielóides e linfócitos $T$. O receptor $C_{200} R$ potencialmente pode promover a proliferação de células infectadas por HHV-8 mediada por citocinas. Trabalhos demonstraram que $\mathrm{vCD}_{200}$ é uma glicoproteina amplamente distribuída na superfície celular de leucócitos e um regulador negativo da sinalização da inflamação produzido por vírus (Chung et al., 2002). Essa atividade também é compartilhada pela ORF 37 do HHV-8, que codifica uma proteína do ciclo lítico com função regulatória da inflamação, denominada SOX (Shutoff ou exonuclease) (Rezaee et al., 2006).

\subsubsection{Enfoque: ORF K1 e ORF K12 do HHV-8}

A primeira ORF do genoma do HHV-8, e de grande interesse no presente estudo, codifica o produto gênico conhecido como K1, com homologia ao receptor de linfócito $B(B C R)$. Foram identificados epítopos funcionais de linfócitos T citotóxicos em regiões variáveis de K1, denominadas VR1 e VR2 (Stebbing et al., 2003). Devido a sua peculiar hipervariabilidade dentro do genoma do HHV-8, a ORF K1 tem sido escolhida para estudos de genotipagem do HHV-8 (Damania, 2004).

A proteína K1 estruturalmente apresenta um domínio extracelular N-terminal, uma região transmembrana e um curto domínio citoplasmático C-terminal que contém ITAM (Immunoreceptor tyrosine-based activation motif ) (Lee et al., 1998; Lagunoff et al., 1997; Damania, 2004) (Figura 4). A importância do produto da ORF K1 na patogênese de SK tem sido demonstrada, uma vez que a alta expressão de K1 
em células endoteliais primárias pode ampliar substancialmente a sua vida útil (Wang et al., 2006; Ganem, 2010). Em linfócitos B, a proteína K1 induz a fosforilação de várias proteínas transdutoras de sinal, como VAV, p85 e AKT quinase (Lagunoff et al, 1999; Tomlinson et al., 2004). K1 tem associação com proteínas celulares que inibem a via Fas indutora de apoptose (Russo et al, 2006) e com propriedades de transformação de fibroblastos, conforme demonstrado por estudos em modelos animais de camundongos transgênicos (Lee et al., 2000). Em modelo experimental de linfoma plasmablástico de camundongos K1 transgênicos, foi observada a produção de fatores de transcrição e aumento da produção e fosforilação da tirosinaquinase. Esses dados parecem indicar que K1 induz alta ativação de fatores de transcrição e quinases celulares que contribuem para o desenvolvimento de linfomas de células B (Prakash et al., 2005).

Membrana plasmática

Núcleo

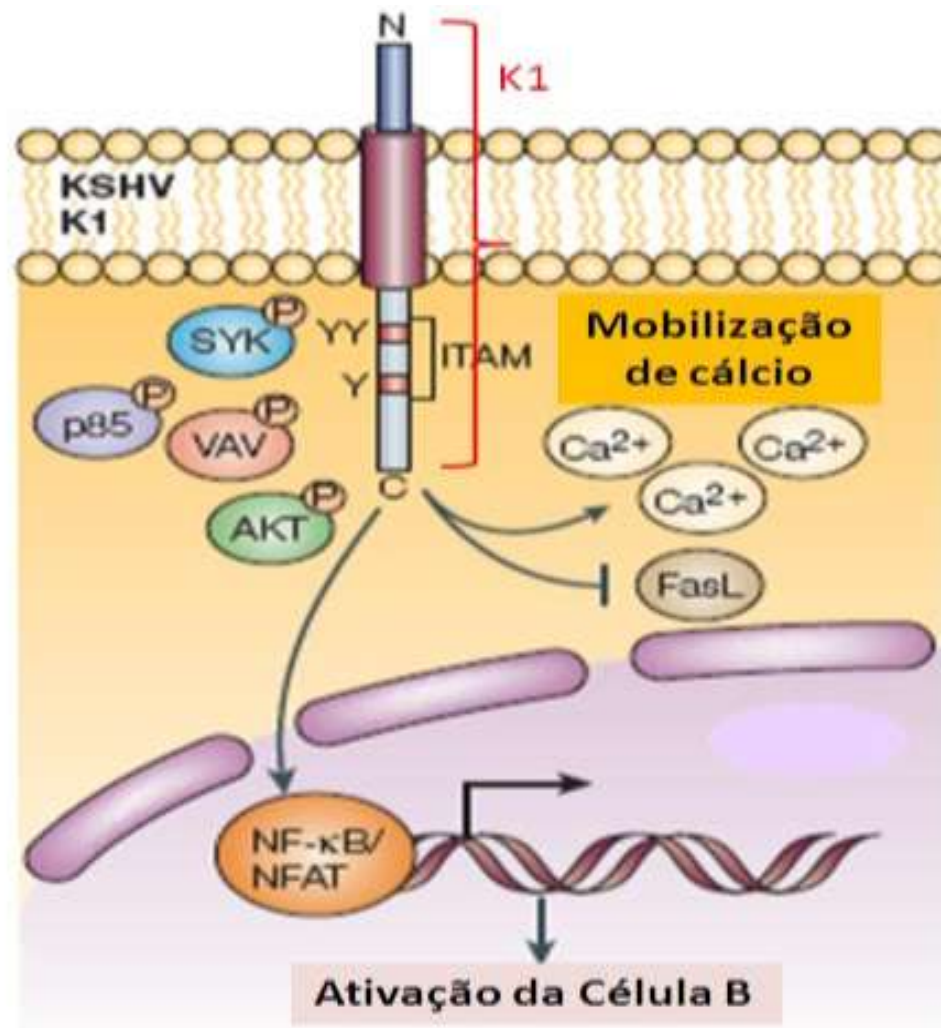

Figura 4 - Destaque da glicoproteína transmembrana codificada pela ORF K1 do HHV-8 com função de transformação celular com motif de tirosina quinase e homologia com receptor de linfócito $B(B C R)$. Modificado de Damania (2004). 
Outro gene do HHV-8 envolvido com a transformação celular é o gene da Kaposina ou ORF K12, cujo produto foi inicialmente destacado por desempenhar importante papel na proliferação celular (Muralidhar et al., 1998). A kaposina foi descrita incialmente como uma proteína hidrofóbica constituída de 60 aminoácidos (Russo et al., 1996; Zhong et al., 1996) e apresentando-se como uma proteína de 16-18 KDa no Western Blotting (Muralidhar et al., 2000). O RNA mensageiro (sigla em inglês RNAm, de Ribonucleic acid mensager) do K12 foi detectado em 85\% das células denominadas fusiformes ou Spindle cells do sarcoma de Kaposi (Russo et al., 1996).

Incialmente, a ORF K12 do HHV-8 foi considerada codificadora de um transcrito complexo de $0.7 \mathrm{~Kb}$, denominado T0.7, que apresenta sequências ricas em GC, com regiões repetitivas que variam de tamanho entre os isolados virais. Mais tarde, Sadler et al. (1999) identificaram que a Kaposina pode apresentar transcrito de até 2,3 Kb, maior do que previamente descrito. Dessa forma, hoje, conclui-se que os produtos da região K12 sejam complexos. Análises genéticas e bioquímicas revelaram que o gene da Kaposina codifica, pelo menos, três isoformas (Kaposinas A, B e C) derivadas de splicing alternativo, de acordo com a fase de leitura do códon de iniciação da tradução (CUG e não AUG) (Sadler el al, 1999).

De modo geral, tem sido sugerido que as isoformas da Kaposina estejam envolvidas com a manutenção do fenótipo tumoral, embora pouco se sabe sobre a Kaposina C. Estudos demostraram que a proteína Tat do HIV e a vIL-6 do HHV-8 aceleram a tumorigênese e a angiogênese (Chen et al., 2009; Zhou et al., 2013) mediana pela Kaposina A, enquanto a Kaposina B mantém a biossíntese (turnover) de citocinas por estabilizar o RNAm das citocinas (McCormick e Ganem, 2005). O produto predominante em linhagem BCBL-1 deriva da tradução a partir do codon 5'CUG do transcrito, resultando na proteina denominada kaposina B. A Kaposina B é considerada o produto gênico de latência que promove um microambiente proinflamatório típico das lesões de SK e do qual tais lesões parecem depender. Foi 
demonstrado que a kaposina B está localizada no membrana do aparato de Golgi, de forma similar a proteína E5 do papilomavírus bovino (PVB) (Muralidhar et al., 2000).

Estudos de polimorfimos no locus $\mathrm{K} 12$ demonstraram a presença de mutações que resultaram no aumento da chance do vírus escapar da resposta imune celular (Guihot et al., 2006; Wilkinson, et al., 2002).

Outros estudos têm destacado a existência de grupos de regiões codificadoras de microRNA no locus $\mathrm{K} 12$, expressos em condições de malignidade do SK. Os microRNAs (miRNAs) são pequenos segmentos de 19-24 nucleotídeos, que regulam a expressão de genes na fase pós transcricional, reconhecendo alvos de RNA mensageiro celulares, que levam a degradação desses. Os miRNAs são codificados no locus da kaposina e na região intergênica adjacente. Os seus transcritos sofrem processamento enzimático para geração dos precursores (primiRNA e pré-miRNA) até a produção dos microRNAs maduros, que atuarão no controle de expressão de genes. Foram identificados os miRNAs do genoma do HHV-8 e, a partir disso, grande ênfase tem sido dado ao polimorfismo em precursores de miRNA, visto que parece interferir no posterior bioprocessamento do miRNA maduro e, consequentemente, na regulação da expressão gênica viral e celular, inclusive de genes do sistema immune (Cai et al., 2005; Pfeffer et al., 2005; Samols et al., 2005; Rezaee et al., 2006; Zhou et al., 2013).

Há um grande interesse do estudo de polimorfismos do locus K12, principalmente os relacionados ao processamento do miRNA, cujos alvos estão envolvidos no controle da apoptose, da transição entre o cíclo latente e lítico do HHV-8, modulação da resposta imune e angiogênese (Samols et al., 2005; Zieugelbauer, 2011; Abend et al., 2012; Ramalingam et al., 2012). Apesar de apresentar sequência de DNA relativamente conservada, como a maioria do genoma do HHV-8, alguns autores têm apontado polimorfismos de um único nucleotídeo ou SNPs (Single Nucleotide Polymorphisms) que parecem associar-se à tumorigênese (Marshall et al., 2010; Ray et al., 2012). Tem sido proposto que o 
SNPs nas regiões codificadoras de miRNA seja um fator de virulência do HHV-8 (Marshall et al., 2010; Lin et al., 2010; Lu et al., 2010; Ray et al., 2012). O locus da ORF K12 contém 2 das 12 regiões codificadora de miRNA até agora descritas. As outras 10 regiões codificadoras de miRNA foram localizadas entre o locus dos genes FLIP e Kaposina (Marshall et al., 2010; Samols et al., 2005). Contudo, o genoma do HHV-8 codifica 12 distintos pré-miRNA que resultam em, pelo menos, 25 miRNA maduros (Lin et al., 2010).

\subsubsection{Diversidade genética do HHV-8}

\subsubsection{Diversidade genética com base na análise isolada de genes}

Os primeiros estudos conduzidos sobre a variabilidade genética do HHV-8 focalizaram dois pequenos fragmentos gênicos da ORF 26 (gene do capsídeo) e ORF 75 (gene da região do tegumento) de exemplares de SK e demonstraram a existência de padrões moleculares distintos porém com reduzida variabilidade nucleotídica $(<3 \%$ 5\%) (Kasolo et al.,1998; Zong et al., 1997; Alagiozoglou et al., 2000; Fouchard et al., 2000; Duprez et al., 2006b; Kasolo et al., 2007).

A abordagem isolada de genes tem trazido informações importantes sobre a origem, evolução e modos de disseminação particular desse oncovírus. Ainda, a avaliação de sequências gênicas do HHV-8 revelou que, embora a maioria do genoma seja relativamente conservada entre os diferentes vírus, um destaque tem sido dado ao primeiro gene, denominado $K 1$, que exibe uma significante hipervariabilidade. Contudo, estudos têm abordado a análise de múltiplos loci do genoma do HHV-8, os quais exibem vários níveis de heterogeneidade na sequência de DNA, tanto com padrões mais conservados, como ORF 26, T0.7/K12, ORF 75, quanto com padrões mais variáveis, como a ORF K1 e a ORF K14.1/ORF K15. Adicionalmente, a análise das regiões do genoma do HHV-8 apontaram 
propriedades importantes como detecção de alguns genomas de HHV-8 quiméricos e padrões genotípicos de HHV-8 comumente presentes em populações relacionadas (Lacoste et al., 2000a, 2000b; Zong et al., 2002; Hayward, 1999; Poole et al, 1999).

A maioria dos trabalhos que definiram variantes de HHV-8 basearam-se, especialmente em regiões do genoma do HHV-8 de maior variabilidade (ORF K1 completa e ORF K15) em grupos de regiões da África, Estados Unidos e Itália (Duprez et al., 2006b; Zong et al., 2002, Mancuso et al., 2008). Os estudos de epidemiologia molecular que exploraram a ORF K1 identificaram 7 subtipos (denominados $A, B, C, D$ ,E, F e Z), os quais exibiram um claro agrupamento genético (Biggar et al., 2000; Cook et al., 1999; Kadyrova et al., 2003; Kakoola et al., 2001; Kasolo et al., 1998; Kazanji et al.,2005; Lacoste et al., 2000a; Lacoste et al., 2000b; Meng et al., 1999; Meng et al.,2001; Nicholas et al., 1998; Whitby et al., 2004; Zong et al., 1999, Zong et al., 2002).

No Brasil, os primeiros estudos para identificar os genótipos de HHV8 foram baseados na análise da ORF 26 do HHV8 (Caterino-de-Arújo et al., 1998; Caterinode Araújo et al., 1999). Reconhecida a hipervariabilidade das regiões VR1 e VR2 da ORF K1, utilizou-se a análise de sequências curtas dessas duas regiões para identificar os genótipos de HHV-8 (Nascimento et al., 2005; Ramos da Silva et al., 2011; Souza et al., 2007b; Ishak et al., 2007; Borges et al., 2012).

Os estudos de diferentes partes do mundo têm se dirigido à busca de maior cobertura geográfica (Meng et al., 2001) e temporal (tornesello et al., 2010; Kouri et al., 2012) da distribuicão do HHV-8, ou ainda da análise de mútliplos genes (Poole et al., 1999; Zong et al., 2002, Whitby et al., 2004). No entanto, em comum, esses trabalhos se basearam na análise do locus K1. A análise das sequências de aminoácidos da região da ORF K1 mostra variabilidade de 40\%; é subdividida em três frações: a porção N-terminal, conservada e composta pelos aminoácidos (aa) 1 ao 19; uma porção central, hipervariável composta pelos aa 20 ao 226, seguido de uma porção C-terminal, relativamente conservada, aa 227 ao 276. Dentro da região 
central da ORF-K1 existem dois fragmentos altamente variáveis denominados VR1 (aa 54 ao 93) e VR2 (aa 191 ao 228) (Hayward, 1999; Zong et al., 1999; Cook et al., 1999). A Figura 5 apresenta a estrutura da proteína da ORF K1, com motivos e domínios específicos ao longo de sua estrutura, destacando as regiões hipervariáveis VR1 e VR2.

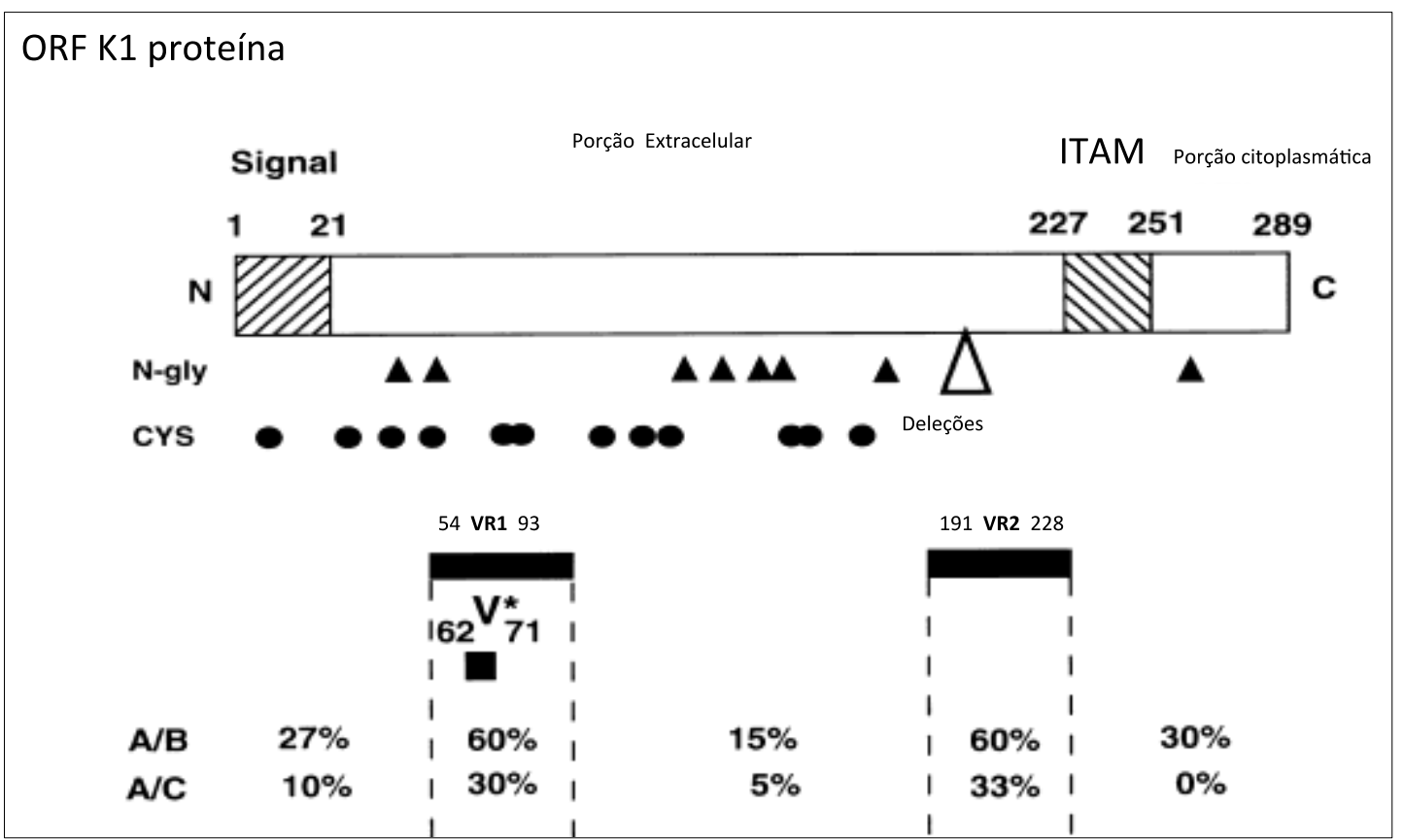

Figura 5 - Predição da estrutura da sequência de aminoácidos (289 aminoácidos) codificada pela ORF K1 do HHV-8. O esquema indica os domínio de peptideo sinal na região $\mathrm{N}$-terminal, as posições de resíduos conservados de cisteína (CYS) e motivos de N-glicosilaçao (N-gly) no dominio extracellular, bem como o motivo ITAM que precede a região Cterminal $(\mathrm{C})$ citomasmática da proteina $\mathrm{K} 1$. As porcentagens indicam as diferenças entre os principiais genótipos $A, B$ e $C$ indicados na região mais variável (VR1 e VR2) e constante dessa proteína K1 de HHV-8, homologa à família das imunoglobulinas. Modificado de Hayward (1999).

Ainda não há um consenso sobre a nomenclatura dos genótipos do HHV-8. Os primeiros genótipos ou subtipos de $\mathrm{K} 1$ foram denominados de $\mathrm{A}$ a $\mathrm{E}$ enquanto os subgenótipos foram denominados de intratipos ou intertipos, representados por letras acrescidas de números (como $A 3, A 5)$ e outros com linha superescrita ( $\left.A^{\prime}, C^{\prime}\right)$ ou acrescidos de números romanos (como A-I, A-II) (Zong et al., 1997; Zong et al., 2002). 


\subsubsection{Distribuição geográfica não ubiqua dos genótipos de HHV-8 no mundo e no Brasil}

As análises filogenéticas têm demonstrado padrões de divergência acumulados durante a migração do homem moderno fora da África, que permitiram identificar variantes genotípicas de HHV-8 não ubiquamente distribuídas. A distribuição geográfica dos genótipos ou subtipos de HHV-8 levaram Hayward (1999) a propôr que um ancestral comum tenha surgido a mais de 100.000 anos e divergiu conforme as migrações do homem primitivo e subsequente isolamento e efeito fundador em populações restritas. Dessa forma, a primeira migração do homem através da África subsaariana começou a 100.000 anos, sendo o genótipo B o mais ancestral; a segunda migração dirigiu-se ao sul da Ásia, Australia, Taiwan e ilhas do Pacífico há 60.000 - 70.000 anos (genótipo D); a terceira migração formou a separação do terceiro ramo para a Europa e norte da Ásia há 35.000 anos (genótipos A e C) com posterior expansão para as Américas (genótipo E) há cerca de 15.000 anos, e para o Norte da Europa há 10.000 anos atrás, no final da era do gelo (Zong et al., 2002). A Figura 6 mostra a relação filogenética e a distribuição geográfica dos principais genótipos (também denominados de subtipos) baseada no locus $\mathrm{K} 1$ do HHV-8. 




Figura 6 - Distribuição geográfica dos principais genótipos ou subtipos do HHV-8, de acordo com a reconstrução filogenética do gene K1 (Modificado de Cassar et al., 2007).

Esses estudos apontaram que os isolados de HHV-8 do subtipo B predominavam na África e foram filogeneticamente mais distantes do subtipo A e C, os quais foram encontrados em populações da Europa ou em europeus descendentes de americanos do norte (EUA), do que dos subtipos $A$ e $C$ entre si (Cook et al., 1999; Zong et al., 1999; Poole et al., 1999; Fouchard et al, 2000; Kadyrova et al., 2003; White et al., 2008). Enquanto que o subtipo D foi restrito às populações das ilhas do Pacífico (Meng et al., 1999; Zong et al., 1999; Duprez et al., 2006a). O grupamento do subtipo E foi constituído de poucos vírus divergentes, todos encontrados em populações isoladas de ameríndios do Brasil, Guiana Francesa e Equador (Biggar et al., 2000; Kazanji et al., 2005; Souza et al, 2007b; 
Ramos da Silva, et al., 2011). Dois últimos genótipos foram identificados mais recentemente; o subtipo F foi identificado em tribo Bantu na Uganda (Kajumbula et al.,2006) e o subtipo $Z$ foi relatado em uma pequena coorte de crianças na Zambia (Kasolo et al., 2007). Outros subtipos parecem estar confinados em determinadas regiões etnogeográficas, a exemplo o subtipo A5 na África (Zong et al., 2002), mas que também foi apontado no Brasil e no Equador (Nascimento et al, 2005; Whitby et al., 2004).

Dados sobre a variabilidade genética do HHV-8 associado ao HIV no Brasil permanecem escassos ou até mesmo incompletos e abrangeram poucas regiões brasileiras. As investigações detectaram predominantemente os subtipos A, B e C ou E (Caterino-de-Araujo et al., 1998; Biggar et al., 2000; Zong et al., 2002; Nascimento et al., 2005; Ishak et al., 2007; Ramos da Silva, et al., 2011). Esses estudos abordaram apenas pequeno fragmento do locus K1 da região VR1 ou VR2 ou ambos, a maioria de biópsia de SK-aids ou na saliva de ameríndios (Souza et al., 2007b).

Caterino-de-Araujo et al. (1998) relataram pela primeira vez no Brasil a caracterização molecular do HHV-8 ao estudar sete indivíduos com sequências de DNA da ORF 26, as quais foram isoladas de tecido de biópsia de SK- aids em São Paulo. Três pacientes foram de origem italiana, três de origem portuguesa e um de origem arábe. Os isolados de HHV-8 desses agruparam predominantemente nos subgrupos B e C.

Biggar et al. (2000) avaliaram as sequências da ORF K1/HHV-8 em Ameríndios da região Amazônica e verificaram que tinham 95\% de identidade uma da outra, mas elas diferiram dos quatro genótipos (subtipos) previamente reportados em $25-30 \%$. Dessa forma, o subtipo $E$ foi pela primeira vez relatado, em áreas hiperendêmicas de HHV-8 em amerindios do Brasil, embora a presença de SK não tenha sido relatada. Posteriormente, o subtipo E também foi descrito em tribos da Guiana Francesa com infecção assintomática por HHV-8 (Whitby et al., 2004) e na saliva de ameríndios da Amazônia (Souza et al., 2007b). 
Zong et al. (2002) relataram a caracterizaçao molecular de três casos de SK-aids no Brasil, e mostraram a presença dos subtipos A1, A8, e C3.

Ishak et al, 2007 identificaram os subtipos E e C em tribos de índios da região amazônica e subtipo B em um caso de HIV/ SK em zona urbana do Pará.

Nascimento et al., 2005 relataram a caracterização molecular do HHV-8 e4m 33 amostras de biópsia de SK de pacientes HIV-SK em São Paulo. Dezenove de origem Caucasiana, nove de descencia Africana, quatro de mistura étnica, e um paciente relatou descendência amazônica. $\mathrm{O}$ três subtipos $\mathrm{A}, \mathrm{B}$ e $\mathrm{C}$ do HHV-8 foram detectados na proporção de $48 \%, 21 \%$, e $30 \%$, respectivamente.

Ramos da Silva et al. (2011) detectaram os genótipos A (50\%), B (2\%) e C (48\%) em biópsia de SK associado ao HIV em região do interior de São Paulo. Esses autores apontaram maior frequência do genótipo A e C em SK associado à aids e SK clássico, respectivamente.

\subsubsection{A perspectiva em identificar o potencial patogênico associado ao genótipo viral ou a variabilidade genética viral}

Assim como acontece com outros vírus com potencial patogênico que infectam o homem, como o poliomavírus JCV (John Cunningham virus), Hepatite C vírus (HCV) e papilomavírus humano (HPV), a relação dos genótipos virais e repercussão clínica tem sido identificada em contextos específicos, de modo que é plausível esperar que haja uma associação de genótipos ou polimorfismos de HHV-8 como um fator de virulência ou como um marcador prognóstico do SK.

Embora a associação entre potencial patogênico e o genótipo viral tenha sido claramente elucidada em algumas doenças humanas causadas por vírus, a relação não é tão clara ou ainda representa um grande desafio em outras doenças virais.

Fink et al. (2010) determinaram a caracterização genotípica do vírus JC e sua associação com a leucoencefalopatia multifocal progressiva (LEMP) em pacientes 
com aids em São Paulo, e mostrou associação positiva do genótipo 1 e a LEMP, enquanto que o genótipo 3 mostrou associação inversa à LEMP.

No norte da Itália, Zonatta, et al. (2013) observaram diferença significativa em relação ao genótipo 1 do JC vírus entre pacientes imunocomprometidos (em indivíduos infectados por HIV, Esclerose Múltipla, LEMP) e controles sadios.

O risco de desenvolver câncer em indivíduos infectados por papilomavírus humanos tem sido bem documentado, sendo o tipo 16 do HPV (HPV16) o genótipo mais oncogênico relacionado a vários tipos de câncer, incluindo do útero, da cabeça, do pescoço, anal e pênis (Faridi et al., 2011; Darwich et al., 2013).

Ainda, a identificação do potencial patogênico do genótipo viral tem contribuído para estabelecer a extensão da duração do tratamento da hepatite $C$ em pacientes refratários (Sato et al., 2013) ou para orientar sobre as diferentes vias de transmissão, como demonstrado por Larsen et al. (2010) sobre a associação entre o genótipo 3 do HCV em usuário de drogas, independente da idade, sexo, duração da infecção, uso de álcool ou co-infecção por HIV.

A premissa de que um dado genótipo de HHV-8 esteja relacionado com a progressão para SK tem sido investigada por muitos autores, porém os resultados têm sido inconclusivos (Boralevi et al, 1998; Nascimento et al., 2005; Ramos da Silva, et al., 2011; White et al., 2008; Tornesello et al., 2010; Mancuso et al., 2008; Endo et al., 2003; Marshal., et al., 2010).

Todavia, acreditamos que tal hipótese ainda não tenha sido explorada suficientemente em relação ao HHV-8. Primeiramente, porque é necessária a otimização uniforme na obtenção das sequências da ORF K1 para genotipagem e o estabelecimento de um consenso entre os estudos. Além disso, a abrangência geográfica das análises é incompleta, inclusive no Brasil, em que desconhecemos a prevalência do HHV-8 em muitas áreas. E por último, há ainda poucos estudos que caracterizaram os polimorfismos ou genótipos de HHV-8 comparando grupos com SK e sem SK (Marshall et al., 2010). 
À medida que mais sequências de HHV-8 são descritas, amplia-se a perspectiva de identificação consensual dos genótipos virais, seus subgenótipos e recombinações. Outrossim, amplia-se o conhecimento de características do genoma do HHV-8 e consequentemente, melhores interpretações poderão ser reconhecidas sobre o potencial biológico dessas variações genéticas e do seu impacto clínico.

\subsection{Justificativa}

Estudos da variabilidade genética do HHV-8 poderão trazer melhores interpretações sobre o potencial patogênico dos genótipos de HHV-8 e das variações genotípicas funcionais. Dados sobre a variabilidade genética do HHV-8 no Brasil, predominantemente em que o SK é associado ao HIV, permanecem escassos (Caterino-Araujo et al., 1998; Nascimento et al., 2005; Ishak et al., 2007; Ramos da Silva et al., 2011; Leao et al., 2013).

Nosso estudo propõe analisar a variabilidade genética do HHV-8 no contexto da infecção por HIV na era HAART em São Paulo, Brasil, em indivíduos com sarcoma de Kaposi na era de alta incidência de SK-aids e o perfil genotípico de HHV-8 de indivíduos infectados por HIV sem histórico de SK.

No Brasil, ainda não há estudos sobre a análise da variabilidade genética do HHV-8 em indivíduos infectados por HIV com e sem SK. 


\subsection{Objetivo geral}

Analisar a variabilidade genética do HHV-8 em indivíduos infectados por HIV com sarcoma de Kaposi e em indivíduos infectados por HIV sem histórico de SK para identificar se existe relação entre algum genótipo ou subgenótipo do HHV-8 com evolução para SK.

\subsection{Objetivos específicos}

2.2.1 identificar em pacientes com SK se existe relação entre genótipos de HHV-8 com: episódios de piora de SK, estadio clínico do SK, níveis de CD4+, carga viral de HIV, idade, sexo, cor de pele, categoria de risco para aquisição de HIV , tempo de infecção por HIV e de adoecimento com aids e de tempo de uso de ART.

2.2.2 Identificar em indivíduos infectados por HIV sem SK se existe relação entre genótipos de HHV-8 com níveis de CD4+, carga viral de HIV, carga viral de HHV-8, idade, sexo, cor de pele, categoria risco para aquisição de HIV e tempo de infecção por HIV e de adoecimento com aids e tempo de uso de ART.

2.2.3 Identificar a variabilidade genética do HHV-8 através de análise do locus ORF K1 entre os grupos de estudo, por meio da detecção de recombinações, análise de relações filogenéticas, mutações silênciosas e não silênciosas, e variabilidade intrahospedeiro (variabilidade genotípica de HHV-8 quando 
houver mais de uma amostra biológica com sequência de DNA/ HHV-8 do mesmo indivíduo).

2.2.4 Comparar os padrões de variabilidade do locus da Kaposina (ORF K12) entre o grupo com e sem KS, em particular quanto aos polimorfismos de um único nucleotídeo em regiões codificadoras de microRNA

2.2.5 Avaliar o uso do conjunto de primers da ORF K1 completa e parcial (K1/VR1 e K1/VR2) para identificação dos genótipos/subgenótipos de HHV-8. 


\section{CASUÍSTICA E MÉTODOS}




\subsection{Casuística e desenho do estudo}

O estudo foi desenhado para investigar a variabilidade genética do HHV-8 no contexto do sarcoma de Kaposi associado à aids em um grupo selecionado a partir de 37 indivíduos com SK ativo, na ocasião de alta incidência de SK (1998 ou 1999), e de um grupo selecionado a partir de 751 indivíduos infectados por HIV, mas sem histórico de SK (92\% infectados por HIV entre 1987 a 2003, e sem SK até o momento). Ambos os grupos atendidos na "Casa da aids" - Departamento de Moléstias Infecciosas e Parasitárias do Hospital das Clínicas da Faculdade de Medicina da Universidade São Paulo, Brasil.

O grupo 1 foi constituído a partir 37 indivíduos infectados por HIV com registro da presença ativa do SK. Cinco $(n=05)$ indivíduos do grupo 1 tiveram amostras seriadas de sangue colhidas em diferentes períodos (entre 1998 a 1999) (amostras SKL-9-1 e SKL9-3; SKL63-1, SKL63-3; SKL69-1, SKL-69-2, SKL-69; SKL-31-1, SKL-31-3, SKL-31-10, SKL31; SKL47-1 e SKL47-4). Adicionalmente, dois ( $n=02)$ indivíduos com SK tiveram coleta de sangue em 1999 e de saliva em 2007 (amostras SKL5FOX25 e SKL22FOX30) e a variabilidade de HHV-8 entre essas amostras também foi investigada. No total, 47 amostras foram analisadas.

O segundo grupo de estudo foi constituído a partir da investigação de DNA de HHV-8 nas salivas de um total de 751 indivíduos infectados por HIV sem histórico de manifestação atual ou prévia de SK. Desse total, foram selecionadas as amostras positivas para DNA da ORF 73 de HHV-8 na saliva, a fim de compor o grupo de indivíduos co-infectados por HIV e HHV-8. Adicionalmente, um indivíduo ( $\mathrm{n}=01)$ teve coleta de sangue e saliva pareadas na mesma ocasião, e a variabilidade do HHV-8 foi também investigada em ambas as amostras biológicas. 
O desenho do estudo para a composição dos grupos foi esquematizado na Figura 7, abaixo.

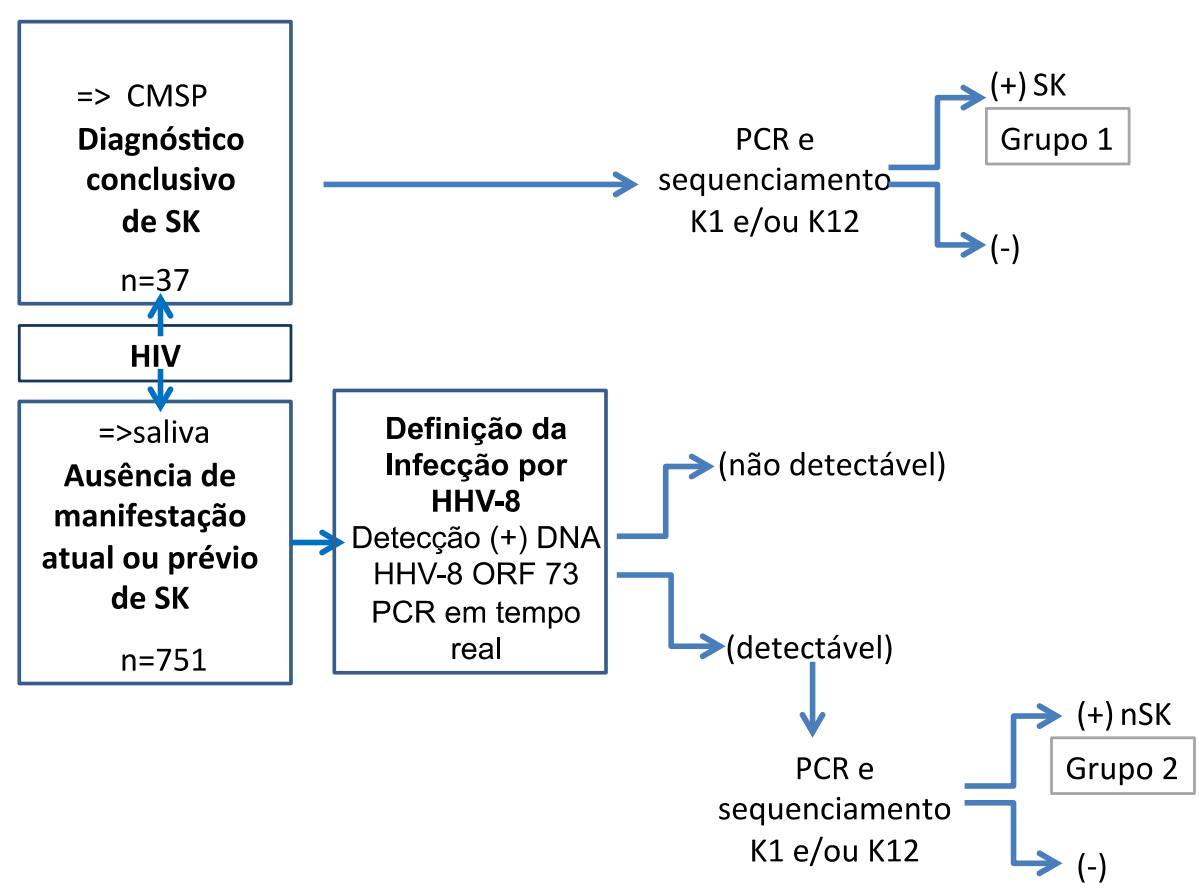

Figura 7 - Desenho do estudo: seleção dos indivíduos infectados por HIV pertencente aos grupos com SK (grupo 1-SK) e sem SK (grupo 2- nSK) para investigação da variabilidade genética do HHV-8

\subsection{Parecer ético}

O protocolo atual foi aprovado pela Comissão de Ética para Análise de Projetos de Pesquisa (CAPpesq) sob Registro 290/2011. O estudo foi feito a partir de amostras de CMSP ou saliva criopreservadas que foram obtidas do Banco de Materiais Biológicos do Instituto de Medicina Tropical de São Paulo (IMTSP), Laboratório de viorologia, LIM 52. O acesso foi restrito ao coordenador do Banco de Material Biológico (Vanda Ueda Akiko Fick de Souza) a quem designou à pesquisadora principal o acesso ao mesmo. Foi garantido o anonimato dos pacientes, resguardando a confidencialidade das informações. A assinatura do 
termo de consentimento livre e esclarecido foi obtida de todos os indivíduos anteriormente a coleta do material biológico, segundo os protocolos previamente aprovados pela CAPPesq da Diretoria do Hospital das Clinicas da Faculdade de Medicina da Universidade de Sao Paulo sob registro 177/98 e 0290/07.

\subsection{Definições dos grupos de estudo com e sem SK}

\subsubsection{Grupo 1 - HIV SK}

Os indivíduos infectados por HIV com SK do grupo 1 foram classificados previamente pela Dra. Ligia C. Pierrotti (protocolo de estudo registrado 177/98 CAPPESq), de acordo com o estadio do tumor e extensão da lesão definida pelo sistema proposto por Krigel et al, 1983. Os estadios I, II, III e IV foram caracterizados pela presença de lesões cutâneo-mucosas localizadas indolentes, localmente agressivas, disseminadas e viscerais, respectivamente.

Os dados sobre a evolução clínica do SK foram registrados num intervalo de um ano (sob uso de terapia antirretroviral), baseando-se na presença de episódio de piora de SK, definida pelo aumento maior ou igual a $25 \%$ das lesões e/ou aparecimento de novas lesões e/ou novos sítios de aparecimento do tumor e/ou piora do aspecto das lesões (de máculas para placas ou nódulos e edema), seguindo critérios descritos por Krown, et al., 1989. Os critérios de inclusão para compor o grupo 1 - SK foram: - diagnóstico conclusivo de SK por avaliação anatomopatológica e clínica do tumor em atividade; - detecção de fragmento gênico por PCR da ORF K1 ou ORF K12 de HHV-8 a partir de células mononucleares do sangue periférico (CMSP) e obtenção das sequências de DNA de HHV-8. O código das amostras pertencente ao grupo 1 foi precedida do prefixo SKL ou SKFOX. 


\subsubsection{Grupo 2 - HIV não SK (nSK)}

Os indivíduos infectados por HIV sem SK compuseram o grupo 2 - nSK. Os critérios adotados para a composição do grupo 2 foram: - ausência de manifestação atual ou prévia de SK; - presença da co-infecção HIV e HHV-8 definida pela positividade de DNA da ORF73 do HHV-8 na saliva; - positividade para a região do locus da ORF K1 ou ORF K12 e obtenção da sequência de DNA do HHV-8. O código das amostras pertencentes ao grupo 2 foi precedida do prefixo nFOX.

Esse grupo foi definido como grupo de comparação, e a análise do tipo caso e controle foi definida, no mínimo, para uma proporção de 1:1.

\subsection{Processamento do material biológico e obtenção, purificação e controle de qualidade do DNA total obtido}

Amostras de células mononucleares do sangue periférico (CMSP) de indivíduos infectados por HIV do grupo 1 (com SK) foram previamente isoladas por gradiente de concentração em Ficoll Hypaque (Sigma), densidade 1,077, a partir de $5 \mathrm{~mL}$ de sangue total coletado em tubo Vacutainer $^{\circledR}$ contendo EDTA (

). Após a lavagem das CMSP em tubo cônico, foi realizado o processo de criopreservação em solução de DMSO (Dimetilsulfóxido) a 10\% (Sigma) em PBS e estocado em nitrogênio líquido até o momento do uso.

A obtenção de salivas dos indivíduos do grupo 2 (HIV, não SK) foi baseada no protocolo realizado por Beyari et al, 2003. As salivas foram coletadas após bochecho com $5 \mathrm{~mL}$ de salina e um volume de $200 \mu \mathrm{L}$ foi obtido por centrifugação a $800 \mathrm{~g}$ em tubo cônico. As amostras foram aliquotadas em criotubos e estocadas em freezer $-70^{\circ} \mathrm{C}$ até o momento do uso. 
As extrações de DNA total dos materiais biológicos (CMSP e sedimento salivar) foram feitas através do uso do Kit Genomic DNA extraction (Real Genomics ${ }^{\mathrm{tm}}$, Real Biotech Corporation), segundo instruções do fabricante. As amostras foram processadas em três ambientes físicos diferentes em cada etapa do procedimento, a fim de prevenir contaminações: 1) área de extração de ácidos nucléicos, 2) área de preparo dos reagentes -pré-PCR, 3) área de amplificação de DNA, distribuição do produto de nested PCR e detecção dos fragmentos de DNA pós PCR.

No mínimo, três controles negativos (água MilliQ) foram usados por ensaio e intercalados entre as amostras. Amostras de DNA obtidas da linhagem de células de linfoma de efusão primário (PEL) imortalizadas pela infecção por HHV-8 (linhagem BCBL-1, mantida em cultura no laboratório de Virologia) foram empregadas como controle positivo dos testes e de eficiência da reação de PCR. As amostras obtidas da extração de DNA foram submetidas à reação de amplificação de $\beta$-globina humana para avaliação da viabilidade do DNA, conforme Saiki et al, 1985.

\subsection{Definição da co-infecção HIV e HHV-8 na ausência do sarcoma de Kaposi}

Amostras de saliva do grupo 2 foram analisadas por PCR em tempo real a fim de identificar a co-infecção por HHV-8 através da detecção de DNA da ORF 73 de HHV-8 na saliva, conforme descrito a seguir.

\subsubsection{Método PCR em tempo real ORF 73}

O PCR em tempo real foi realizado pelo sistema TaqMan® a partir de amostras de DNA, com uso dos primers/sondas (Tabela 1) que amplificaram um 
produto de 68 pb do gene que codifica para a proteína nuclear latente (ORF 73), conforme descrito por Krishnan et al., 2004. A curva padrão foi estabelecida a partir da concentração conhecida do plasmídeo pGEX-5X (gentilmente cedido pelo Prof. Harutaka Katano, Instituto de Doenças Infecciosas, Tokyo, Japão), contendo o inserto da ORF73 do HHV-8. O limite de detecção previamente ensaiado foi de 4 cópias de plasmídeo.

Tabela 1 - Primers e sonda marcada segundo Krishnan (2004) para uso em PCR em tempo real

\begin{tabular}{cc}
\hline Primers & Sequências - ORF 73 \\
\hline Forward & 5'-CGCGAATACCGCTATGTACTCA-3' \\
Reverse & 5'-GGAACGCGCCTCATACGA-3' \\
Sonda TAMRA & 6FAM-5'ACATCACCACCCCACAGACCTGGAG 3'- \\
\hline
\end{tabular}

O ciclo de amplificação foi realizado em aparelho ABI PRISM 7300 (Applied Bisystems). A solução para amplificação de uma única amostra continha $12,5 \mu \mathrm{L}$ do reagente TaqMan ${ }^{\circledR}$ Universal PCR Master Mix (Applied Biosystems) 0,6 $\mu \mathrm{L}$ de cada primer na concentração final de $125 \mathrm{nM} ; 0,3 \mu \mathrm{L}$ de sonda específica para a ORF 73 na concentração final de $62 \mathrm{nM} ; 1 \mu \mathrm{L}$ de água livre de nucleases DEPC (Treated Water - Pyrogen-free Certfied DNAse/RNAse free - Invitrogen) e $10 \mu \mathrm{L}$ de amostra de DNA, totalizando $25 \mu \mathrm{L} /$ tubo. As condições da reação do PCR em tempo real foram: $50^{\circ} \mathrm{C}$ por 2 minutos; $95^{\circ} \mathrm{C}$ por 10 minutos e 40 ciclos de $95^{\circ} \mathrm{C}$ por 15 segundos e $60^{\circ} \mathrm{C}$ por um minuto. 


\subsection{Análise Molecular do HHV-8}

Sequências de DNA de HHV8 de indivíduos infectados por HIV dos grupos 1

e 2 foram submetidas ao estudo da variabilidade da região da ORF K1 e da ORF K12, conforme apresentado no esquema da Figura 8, detalhado nos ítens 3.6.1 e 3.6.2.

\section{A - Locus K1}

ORF K1 -867 pb

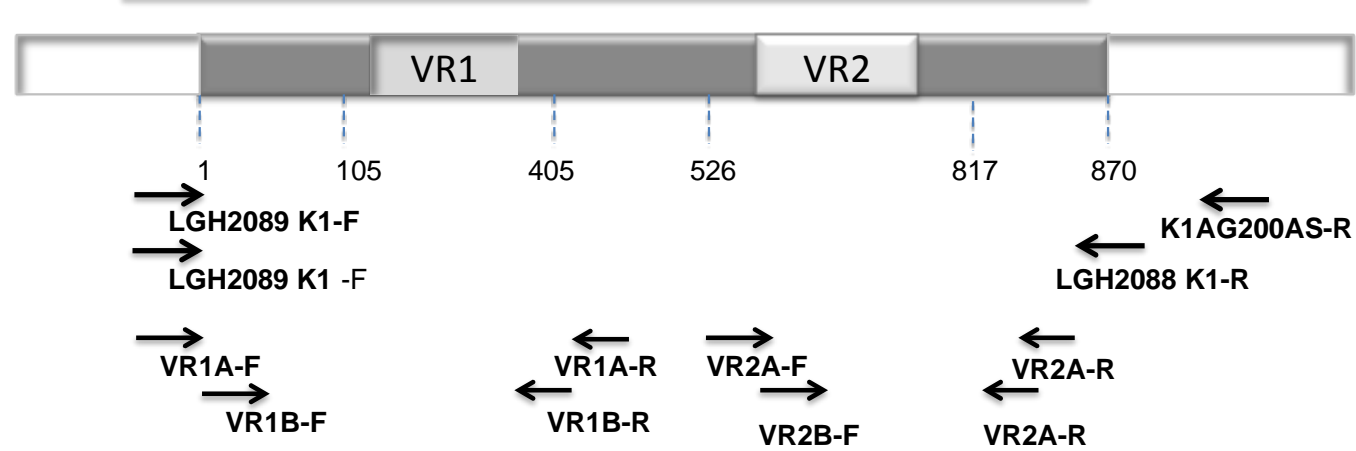

B - Locus K12

ORF K12 (T0.7) - $752 \mathrm{pb}$

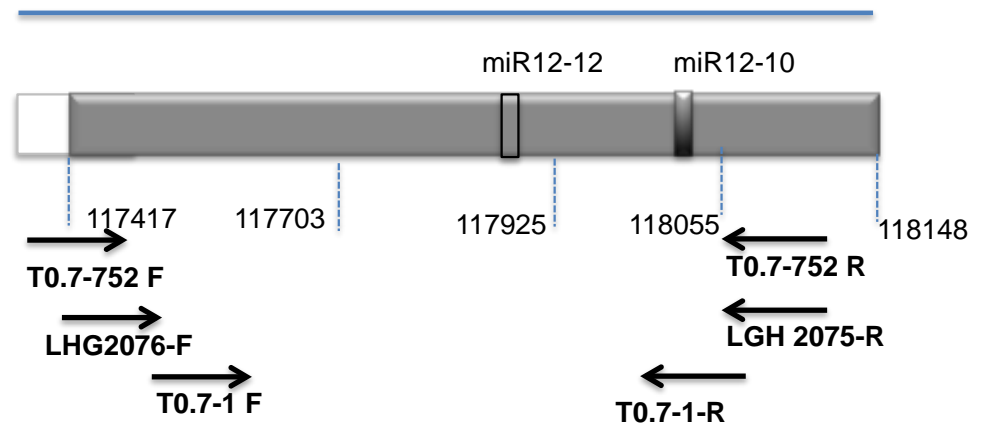

Figura 8 - Esquema da coordenada dos primers para amplificação dos loci investigados nesse estudo. A. Locus ORF K1. B. Locus ORF K12. As barras (cor preta) transversais ao esquema do locus $\mathrm{K} 12$ representam a localização das regiões codificadoras de miRNA (miR12-12; miR12-10). Os números abaixo das barras pontilhadas se referem as posições dos nucleotídeos (coordenadas) no genoma do HHV-8 e as setas indicam as posições dos primers externos e internos K1, VR1, VR2, T.07 no sentido Forward e Reverse. A posição dos primers nesse esquema é aproximada, com fim ilustrativo. 


\subsubsection{Amplificação da ORF K1 parcial (K1/VR1 e K1/VR2) e completa do genoma do HHV8}

Amostras de DNA de HHV-8 positivas para as regiões parciais K1/VR1 e K1/VR2 foram obtidas por nested PCR, gerando fragmentos de 386 e $375 \mathrm{pb}$, respectivamente, com os primers Forward e reverse descritos na Tabela 2 segundo Stebbing et al., 2003. As condições do PCR K1/VR1 para o primeiro e segundo round foram: $95^{\circ} \mathrm{C}$ por $2 \mathrm{~min}, 40$ ciclos de $94^{\circ} \mathrm{C}$ por $30 \mathrm{~s}, 61^{\circ} \mathrm{C}$ por $45 \mathrm{~s}, 72^{\circ} \mathrm{C}$ por 1 min; e $72^{\circ} \mathrm{C}$ por $10 \mathrm{~min}$. As condições do PCR K1/VR2 foram iguais, exceto a temperatura de pareamento das sondas (primers annealing), que no primeiro round foi de $59^{\circ} \mathrm{C}$ e no segundo, de $56^{\circ} \mathrm{C}$.

Ainda, de forma alternativa, a região codificadora do gene $\mathrm{K} 1$ completo (867 pb) foi obtida por nested PCR Touch Down, com os primers descritos por Poole, et al., 1999 e Lacoste et al,. 2000a (Tabela 2). As condições do PCR foram iguais em termos de concentração de reagentes para ambos, primeiro e segundo rounds: solução tampão composta de 50 mM de $\mathrm{KCl}$ e $10 \mathrm{mM}$ de Tris pH 9,0 (Invitrogen ${ }^{\mathrm{TM}}$, USA) $1 \mathrm{X}$ diluída em água livre de DNase/RNase (UltraPure ${ }^{T M}$ Destilated Water, Life techonologies) contendo 0,2 mM de dNTPs; $2 \mathrm{mM}$ de $\mathrm{MgCl}_{2} ; 0,4 \mu \mathrm{M}$ de primer forward LGH2089 e reverse K1AG1200AS; 1U de Taq DNA polimerase Platinum (Invitrogen ${ }^{\mathrm{TM}}$, Carisbad, CA, USA) e $5 \mu \mathrm{L}$ da amostra de DNA total para um volume final de $25 \mu \mathrm{L}$. O segundo round de amplificação foi feito com os primers foward LGH2089 e reverse LGH2088 (Tabela 2). As condições de temperatura do primeiro round de amplificação foram: $95^{\circ} \mathrm{C}$ por $3 \mathrm{~min}$, e 10 ciclos de $95^{\circ} \mathrm{C}$ por $30 \mathrm{~s}$, de 60 a $55^{\circ} \mathrm{C}$ com redução de $0,5^{\circ} \mathrm{C}$ a cada ciclo, e 35 ciclos de $95^{\circ} \mathrm{C}$ por $30 \mathrm{~s}, 55^{\circ} \mathrm{C}$ por 30 s, $72^{\circ} \mathrm{C}$ por $60 \mathrm{~s}$, e $70^{\circ} \mathrm{C}$ por 3 min (Touch Down PCR). As condições de ciclagem do segundo round foram iguais ao primeiro round, porém com a temperatura de pareamento das primers (primers annealing) decrescendo de $60^{\circ} \mathrm{C}$ à $50^{\circ} \mathrm{C}$ com redução de $1^{\circ} \mathrm{C}$ a cada ciclo (Touch Down PCR). 
Tabela 2 - Conjunto de primers usados na amplificação completa e parcial da ORF K1 do HHV8

\begin{tabular}{|c|c|c|c|}
\hline ORF K1 & Sequências dos primers 5'-3' & Produto & Referências \\
\hline $\begin{array}{l}\text { Forward } \\
\text { LGH2089 }\end{array}$ & GTTCTGCCAGGCATAGTC & & $\begin{array}{c}\text { Poole al., } \\
1999\end{array}$ \\
\hline $\begin{array}{l}\text { Reverse } \\
\text { K1AG1200AS }\end{array}$ & AGGCCATGCTGTAAGTAGCACGGTT & $1065 \mathrm{pb}$ & $\begin{array}{l}\text { Lacoste et al., } \\
2000 a\end{array}$ \\
\hline $\begin{array}{l}\text { Forward } \\
\text { LGH2089 }\end{array}$ & GTTCTGCCAGGCATAGTC & & $\begin{array}{c}\text { Poole et al., } \\
1999\end{array}$ \\
\hline $\begin{array}{l}\text { Reverse } \\
\text { LGH2088 }\end{array}$ & AATAAGTATCCGACCTCAT & $867 \mathrm{pb}$ & $\begin{array}{c}\text { Poole et al., } \\
1999\end{array}$ \\
\hline $\begin{array}{l}\text { VR1A } \\
\text { Forward }\end{array}$ & GTTCTGCCAGGCATAGTC & & $\begin{array}{c}\text { Stebbing et al., } \\
2003\end{array}$ \\
\hline $\begin{array}{l}\text { VR1A } \\
\text { Reverse }\end{array}$ & GTAACATGCTGACCACAAG & & $\begin{array}{c}\text { Stebbing et al., } \\
2003\end{array}$ \\
\hline $\begin{array}{l}\text { VR1B } \\
\text { Forward }\end{array}$ & CTGGCGGCCCTTGTGTAAAC & $386 \mathrm{pb}$ & $\begin{array}{l}\text { Stebbing et al., } \\
2003\end{array}$ \\
\hline Reverse & GACTGTGTTTGATGGCTGTGC & & \\
\hline $\begin{array}{l}\text { VR2A } \\
\text { Forward }\end{array}$ & CGTCTCGCCTGTCAAATC & & $\begin{array}{l}\text { Stebbing et al., } \\
2003\end{array}$ \\
\hline Reverse & ACTGGTTGCGTATAGTCTTCC & & \\
\hline $\begin{array}{l}\text { VR2B } \\
\text { Forward }\end{array}$ & GTATATGTTTTTGGGCGCGTTG & $375 \mathrm{pb}$ & $\begin{array}{c}\text { Stebbing et al., } \\
2003\end{array}$ \\
\hline Reverse & CCGTGCACAAATCGTGTAGGG & & \\
\hline
\end{tabular}

\subsubsection{Amplificação da ORF K12 do HHV-8}

As condições do PCR para amplificação de um fragmento de 752 pb da ORF K12 (T0.7) foram previamente descritas conforme Whitby et al., 2004, com algumas modificações. O nested PCR foi desenvolvido com as concentrações de 0,2 mM de dNTPs; 2 mM de $\mathrm{MgCl}_{2} ; 0,4 \mu \mathrm{M}$ de primers forward e reverse e $1 \mathrm{U}$ de Taq Platinum (Invitrogen ${ }^{\mathrm{TM}}$ Life Technologies, Carisbad, CA, USA). As condições de temperatura do primeiro round foram: $94^{\circ} \mathrm{C}$ por 3 minutos e 35 ciclos de $94^{\circ} \mathrm{C}$ por 30 segundos, $61^{\circ} \mathrm{C}$ por 30 segundos, $72^{\circ} \mathrm{C}$ por 60 segundos, e $72^{\circ} \mathrm{C}$ por 3 minutos. Quando o 
fragmento de 752 pb do produto de PCR do primeiro round não fosse visualizado em gel, um segundo round de amplificação (nested PCR) foi realizado a partir de $5 \mu \mathrm{L}$ do produto de PCR do primeiro round, com os primers LGH (Poole et al., 1999) ou T0.7-1 (Whitby et al., 2004), gerando os fragmentos de 646 ou 407 pb, respectivamente (Tabela 3). As condições do segundo round foram as mesmas descritas para o primeiro round de amplificação.

Tabela 3 - Primers para amplificação da ORF K12: um fragmento de 752 pb (primeiro round) e alternativamente, 646 e 407 pb (segundo round) da ORF K12 (T0.7)

\begin{tabular}{|c|c|c|c|}
\hline ORF K1 (T0.7) & Sequências dos primers 5'-3 & Produto & Referências \\
\hline $\begin{array}{l}\text { T0.7-752 } \\
\text { Forward }\end{array}$ & TGCAACTGACCATGTTCAGGT G & $752 \mathrm{pb}$ & $\begin{array}{c}\text { Whitby }(100) \text { et } \\
\text { al.,2004 }\end{array}$ \\
\hline Reverse & СТССТСССТССТСАСТССААТС & & \\
\hline $\begin{array}{l}\text { LGH } 2076 \\
\text { Forward }\end{array}$ & GCTGCAATGTACTGCCATG & $646 \mathrm{pb}$ & $\begin{array}{c}\text { Poole et al., } \\
1999\end{array}$ \\
\hline $\begin{array}{l}\text { LGH } 2075 \\
\text { Reverse }\end{array}$ & СТССААТCCСАATGCATGGA & & \\
\hline $\begin{array}{l}\text { T0.7-1 } \\
\text { Forward }\end{array}$ & ACTTGGCGTCTGCCGAAGTC & $407 \mathrm{pb}$ & $\begin{array}{l}\text { Whitby et } \\
\text { al.,2004 }\end{array}$ \\
\hline Reverse & TAGCGTGCCCTCCCAAAGAG & & \\
\hline
\end{tabular}

\subsubsection{Avaliação dos Produtos de PCR da ORF K1 parcial (K1/VR1, K1/VR2) e completa ou ORF K12}

\subsubsection{Identificação dos Fragmentos de DNA alvo em gel de agarose}

Os produtos de PCR obtidos em quaisquer das reações de amplificação foram visualizados através de eletroforese em gel. Para tanto, foram submetidos à corrente constante de 65 amperes em gel de agarose 1,5\% (Agarose Ultrapure ${ }^{\mathrm{TM}}$, Invitrog 
peso molecular de $100 \mathrm{pb}$ (Invitrogen, USA) foi utilizado como referência. Amostras positivas foram selecionadas para a etapa posterior de purificação e sequenciamento de DNA.

\subsubsection{Purificação do produto de PCR e Reação de Sequenciamento de DNA}

Os produtos de nested PCR identificados como positivos foram submetidos a um processo de purificaçã

(QIAquick® PCR Purification kit, Qiagen). Subsequentemente, foi feita a semi-quantificação dos fragmentos de DNA alvo de HHV-8, tendo como base um marcador de massa molecular comercial Low DNA Mass Ladder (Gibco) como referência.

A reação de sequenciamento foi realizada pelo sistema do kit Big Dye ${ }^{\mathrm{TM}}$ Terminator v 3.1 Cycle Sequencing Ready Reaction (Applied Biosystems, Foster City, CA, USA), baseado no uso de didesoxinucleotídeos (ddNTPs), contendo marcadores fluorescentes. A reação foi realizada em placas MicroAMP® Optical 96well Reaction Plate (Applied Biosystems, Foster City, CA). A mistura de reagentes foi preparada com 4,4 $\mu \mathrm{L}$ de Save Money, 3,2 pmol de primer, 20 ng de DNA da amostra (produto de PCR purificado), $2 \mu \mathrm{L}$ de BygDye sequency ${ }^{\mathrm{TM}}$ contendo os nucleotídeos terminadores, e água deionizada comercial livre de DNAse (Gibco) para um em um volume final de $20 \mu \mathrm{L}$. A reação de sequenciamento foi desenvolvida nas seguintes condições: 30 ciclos de $96^{\circ} \mathrm{C}$ por 20 segundos, $50^{\circ} \mathrm{C}$ por 20 segundos e $60^{\circ} \mathrm{C}$ por 4 minutos.

Posteriormente, o produto obtido foi novamente purificado, visando à remoção de nucleotídeos terminadores não incorporados na reação, através do método de precipitação com isopropanol a 75\%. O método consiste em adicionar $80 \mu \mathrm{L}$ de isopropanol $75 \%$ a cada um dos poços da placa de sequenciamento, agitar por vortex, incubar no escuro por 15 minutos a temperatura ambiente, centrifugar a 
placa por 45 minutos a 1500-2000 g. Após, o álcool foi removido por inversão e centrifugação invertida a $200 \mathrm{~g}$ por 1 minuto e incubado em termociclador a $95^{\circ} \mathrm{C}$ por 2 minutos para a total evaporação. O sedimento seco foi ressuspenso em $10 \mu \mathrm{L}$ de formamida $\mathrm{Hi}$-Di $10 \%$ e as amostras submetidas ao Sequenciador Automático ABI 3100 (Applied Biosystems, Foster City, CA, USA). A avaliação da qualidade das sequências foi baseada no algoritmo Phred apresentado em arquivo phd, e por meio do programa SeqMan/Lasergene (www.dnastar.com) e Sequencher (genecodes.com), considerando a altura e distância regular entre os picos do perfil do cromatograma.

\subsection{Análises Moleculares e Filogenéticas}

Os cromatogramas foram analisados pelo programa Lasergene (http://www.dnastar.com/t-sub-products-lasergene-segmanpro.aspx) e as sequências de nucleotídeos foram editadas com o programa Bioedit (www.mbio.ncsu.edu/BioEdit/BioEdit.html). Os arquivos fastas gerados pela edição foram alinhados com sequências de referências de HHV-8, obtidas do GenBank (www.nci.nlm.nih.gov), usando o software ClustalW incorporado ao programa MEGA (Tamura et al., 2011; www.megasoftware.net ).

O método de máxima verossimilhança (MV), do inglês maximum likelihood $(M L)$, foi adotado para as reconstruções filogenéticas desse trabalho. A vantagem de ser um método estatístico e que permite o uso de modelos explícitos de substituição de nucleotídeos foram determinantes na sua escolha. As desvantagens apresentadas pelo método de $\mathrm{MV}$, como tempo computacional e escolha de modelos de substituição com parâmetros adequados não foram um problema, visto que o número de sequências utilizadas, bem como o tamanho das mesmas eram relativamente pequenos. 
Para a escolha do modelo de substituição de DNA mais adequado foi utilizado o programa Modeltest v.0.1 (Posada e Crandall, 1998). O alinhamento, salvo no formato nexus, serviu como entrada para o programa de reconstruções filogenéticas PhyML (Guidon et al., 2003) implementado no pacote SeaView (Gouy et al., 2010). Uma das vantagens do PhyML reside no fato de dispor de várias opções de busca para pesquisar dentro do espaço amostral de possíveis árvores, indo a partir de métodos muito rápido e eficientes (NNI - Nearest Neighbor Interchange, ou troca de vizinhos mais próximos, por exemplo) até métodos com aproximações mais lentas e exatas.

Com o modelo evolucionário adequado para o conjunto de sequências, foram geradas topologias iniciais pelo método de agrupamento de vizinhos (Neighbor Joining $(\mathrm{NJ})$. Em seguida, as topologias sofreram rearranjos (perturbações) através do algoritmo heurístico NNI. Para avaliação da confiabilidade dos eventos de cladogênese, foi executado Bootstrap com 1.000 replicas. A premissa do bootstrap é a independência dos caracteres. Um valor de confiabilidade da repetibilidade do observado (ou seja, a quantidade de vezes que cada ramo aparece na árvore em uma determinada posição), é atribuído. Assim, uma árvore final é construída representando a sumarização do que foi mais frequentemente observado nas repetições. Essa árvore, que em última análise representa o "consenso da maioria", é chamada de majority rule consensus tree. A visualização das reconstruções foi feita com o programa FigTree 1.3.1 (http://tree.bio.ed.ac.uk/software/figtree).

\subsubsection{Referências GenBank}

Os protótipos do HHV-8 obtidos em várias regiões geográficas foram utilizados nas reconstruções filogenéticas. A seguir, a lista de protótipos de HHV-8 obtidos no Genbank usados nesse estudo: loci da ORF K1 ( $\mathrm{n}=48)$ e ORF K12 (T0.7 ou Kaposina) ( $n=20)$, conforme Tabelas 4 e 5. 
Tabela 4 - Protótipos de referência da ORF K1 do HHV-8 e o respectivo genótipo/subgenótipo da ORF K1, segundo dados obtidos do GenBank (http://www.ncbi.nlm.nih.gov/genbank/).

\begin{tabular}{|c|c|c|c|c|c|}
\hline ORF K1 & ID & GenBank & Origem & SK/HHV-8 & Referência \\
\hline $\bar{A}$ & 25Cas & AF178794 & Espanha & MCD & $\begin{array}{l}\text { Lacoste et al., } \\
2000 a\end{array}$ \\
\hline A1 & BCBLR & AF133038 & EUA & PEL & $\begin{array}{c}\text { Nicholas et al., } \\
1998\end{array}$ \\
\hline A1 & US216 & FJ884626 & EUA & SK-AIDS & $\begin{array}{c}\text { Tornesello et al, } \\
2010\end{array}$ \\
\hline A2 & Ema7 & AF130305 & Espanha & SK-AIDS & $\begin{array}{c}\text { Cook et al., } \\
1999\end{array}$ \\
\hline A2 & 17Fuj & AF178786 & Japão & SK-AIDS & $\begin{array}{l}\text { Lacoste et al., } \\
2000 a\end{array}$ \\
\hline A2 & $\mathrm{K} 1-40 / \mathrm{Bc} 1$ & AF178807 & EUA & PEL & $\begin{array}{l}\text { Lacoste et al., } \\
2000\end{array}$ \\
\hline A3 & $\mathrm{K} 1-32 / \mathrm{Bcb}$ & AF178799 & EUA & PEL & $\begin{array}{l}\text { Lacoste et al., } \\
2000 a\end{array}$ \\
\hline A4 & BCBL-B & AF133039 & EUA & PEL & $\begin{array}{c}\text { Zong et al., } \\
1999\end{array}$ \\
\hline A5 & 1IFe1I & AF130282 & Itália & Clássico & $\begin{array}{c}\text { Cook et al., } \\
1999\end{array}$ \\
\hline A5 & IFe5I & AF130284 & Itália & Clássico & $\begin{array}{c}\text { Cook et al., } \\
1999\end{array}$ \\
\hline A5 & K1-13/Lov & AF171057 & G. Francesa & Endêmico & $\begin{array}{l}\text { Lacoste et al., } \\
2000 a\end{array}$ \\
\hline A5 & 58sar & AF178823 & Africa Central & SK-AIDS & $\begin{array}{c}\text { Lacoste et al., } \\
2000 a\end{array}$ \\
\hline B & 431KAP & AF133040 & África & SK-AIDS & $\begin{array}{c}\text { Nicholas et al., } \\
1998\end{array}$ \\
\hline B1 & Ug52 & AF130290 & Uganda & endêmico & $\begin{array}{c}\text { Cook et al., } \\
1999\end{array}$ \\
\hline B1 & UKma24 & AF130301 & Reino Unido & SK-AIDS & $\begin{array}{c}\text { Cook et al., } \\
1999\end{array}$ \\
\hline B1 & $\mathrm{K} 1-11$ & AF178782 & G. Francesa & SK-AIDS & $\begin{array}{c}\text { Lacoste et al., } \\
2000 \mathrm{a}\end{array}$ \\
\hline B1 & $\mathrm{K} 1-12$ & AF178783 & Congo & MCD & $\begin{array}{l}\text { Lacoste et al., } \\
2000\end{array}$ \\
\hline B1 & K1-22/Yan & AF178791 & África Central & SK-AIDS & $\begin{array}{l}\text { Lacoste et al., } \\
2000 a\end{array}$ \\
\hline B1 & $K 1-27$ & AF178796 & África Central & SK-AIDS & $\begin{array}{l}\text { Lacoste et al., } \\
2000 a\end{array}$ \\
\hline B1 & AF178801 & AF178801 & África Central & MCD & $\begin{array}{l}\text { Lacoste et al., } \\
2000 a\end{array}$ \\
\hline B2 & K1-9/Tim & AF171056 & G. Francesa & SK-AIDS & $\begin{array}{l}\text { Lacoste et al., } \\
2000 a\end{array}$ \\
\hline B2 & K1-23/Kok & AF178792 & África Central & SK-AIDS & $\begin{array}{l}\text { Lacoste et al., } \\
2000 a\end{array}$ \\
\hline B2 & K1-37/E44 & AF178804 & Tongo & MCD & $\begin{array}{l}\text { Lacoste et al., } \\
2000 a\end{array}$ \\
\hline B2 & MP5Z & AY042940 & Uganda & Endêmico & $\begin{array}{c}\text { Kakoola et al., } \\
2001\end{array}$ \\
\hline B3 & K1-60/Ced & AF178825 & França & SK-AIDS & Lacoste et al., \\
\hline
\end{tabular}




\begin{tabular}{|c|c|c|c|c|c|}
\hline ORF K1 & ID & GenBank & Origem & SK/HHV-8 & Referência \\
\hline & & & & & $2000 a$ \\
\hline C & $18 \mathrm{Hec}$ & AF178787 & França & SK-AIDS & $\begin{array}{l}\text { Lacoste et al., } \\
2000 \mathrm{a}\end{array}$ \\
\hline C & 10Bid/J21 & AF278843 & Japão & SK-AIDS & $\begin{array}{c}\text { Meng et al., } \\
2001\end{array}$ \\
\hline C1 & GK17 & AF130267 & Grécia & Clássico & $\begin{array}{c}\text { Cook et al., } \\
1999\end{array}$ \\
\hline C1 & D19 & DQ394055 & Marrocos & Clássico & $\begin{array}{c}\text { Duprez et al., } \\
2006 \mathrm{~b}\end{array}$ \\
\hline C1 & ASM72 & AF133041 & EUA & SK-AIDS & $\begin{array}{c}\text { Nicholas et al., } \\
1998\end{array}$ \\
\hline $\mathrm{C} 2$ & D13 & DQ394048 & Marrocos & Clássico & $\begin{array}{c}\text { Duprez et al., } \\
2006 b\end{array}$ \\
\hline $\mathrm{C} 2$ & 14 & DQ394058 & Marrocos & SK-AIDS & $\begin{array}{l}\text { Duprez et al., } \\
2006 \mathrm{~b}\end{array}$ \\
\hline C3 & cam1 & AF130274 & Itália & $\begin{array}{c}\text { latrogênic } \\
0\end{array}$ & $\begin{array}{c}\text { Cook et al., } \\
1999\end{array}$ \\
\hline C3 & $\mathrm{BC} 2$ & AF133042 & EUA & SK-AIDS & $\begin{array}{c}\text { Nicholas, et al., } \\
1998\end{array}$ \\
\hline C3 & D10_1 & DQ394044 & Marrocos & Clássico & $\begin{array}{c}\text { Duprez et al., } \\
2006 b\end{array}$ \\
\hline C3 & D14_1 & DQ394049 & Marrocos & Clássico & $\begin{array}{l}\text { Duprez et al., } \\
2006\end{array}$ \\
\hline C3 & 17 & DQ394060 & Marrocos & SK-AIDS & $\begin{array}{c}\text { Duprez et al., } \\
2006 b\end{array}$ \\
\hline C3 & GK18 & AF148805 & Grécia & Clássico & $\begin{array}{l}\text { Rezaee et al, } \\
2006\end{array}$ \\
\hline C5 & D4_2 & DQ394038 & Marrocos & Clássico & $\begin{array}{c}\text { Duprez et al., } \\
2006 b\end{array}$ \\
\hline C5 & 110 & DQ394064 & Marrocos & SK-AIDS & $\begin{array}{l}\text { Duprez et al., } \\
2006 b\end{array}$ \\
\hline C7 & UKma8 & AF130304 & Reino Unido & SK-AIDS & $\begin{array}{c}\text { Cook et al., } \\
1999\end{array}$ \\
\hline D1 & TKS10TW & AF278846 & Japão & Clássico & $\begin{array}{c}\text { Meng et al., } \\
2001\end{array}$ \\
\hline $\mathrm{D} 2$ & ZKS3 & AF133044 & Ilhas Pacífico & Clássico & $\begin{array}{c}\text { Nicholas, et al., } \\
1998\end{array}$ \\
\hline$E$ & HUA1 & AY329027 & Equador & Endêmico & $\begin{array}{l}\text { Whitby et al., } \\
2004\end{array}$ \\
\hline$E$ & HUA2 & AY329028 & Equador & Endêmico & $\begin{array}{l}\text { Whitby et al., } \\
2005\end{array}$ \\
\hline E1 & Tupi1BR & AF220292 & Brasil & Endêmico & $\begin{array}{l}\text { Biggar et al., } \\
2000\end{array}$ \\
\hline E2 & Tupi2BR & AF220293 & Brasil & Endêmico & $\begin{array}{c}\text { Biggar et al., } \\
2000\end{array}$ \\
\hline $\mathrm{F}$ & K1-43/Berr & AF178810 & França & PEL & $\begin{array}{c}\text { Lacoste et al., } \\
2000 \mathrm{a}\end{array}$ \\
\hline
\end{tabular}


Tabela 5 - Protótipos de referência da ORF K12 do HHV-8 e o respectivo genótipo/subgenótipo da ORF K12 e K1, segundo dados obtidos do GenBank (http://www.ncbi.nlm.nih.gov/genbank/).

\begin{tabular}{|c|c|c|c|c|c|c|}
\hline K12 & $\mathrm{K} 1$ & ID & GenBank & Origem & SK/HHV-8 & Referência \\
\hline$A / C$ & A4 & US_114 & GU238293.1 & EUA & Clássico & $\begin{array}{c}\text { Tornesello, et al., } \\
2010\end{array}$ \\
\hline$A / C$ & A3 & GR_77 & GU238289.1 & Grécia & Clássico & $\begin{array}{c}\text { Tornesello, et al., } \\
2010\end{array}$ \\
\hline$A / C$ & $\mathrm{NI}$ & IR_12 & JN242322.1 & Iran & Clássico & $\begin{array}{c}\text { Jalilvand et al., } \\
2012\end{array}$ \\
\hline B1 & A5 & CM_116 & GU238301.1 & Camarões & Endêmico & $\begin{array}{c}\text { Tornesello, et al., } \\
2010\end{array}$ \\
\hline C4 & A5 & CM_95 & GU2383010.1 & Camarões & Endêmico & $\begin{array}{c}\text { Tornesello, et al., } \\
2010\end{array}$ \\
\hline B & $\mathrm{F}$ & SAN1 & AY329022.1 & Botswana & Endêmico & $\begin{array}{c}\text { Whitby, et al., } \\
2004\end{array}$ \\
\hline E & $\mathrm{NI}$ & HUA5 & AY329021.1 & Equador & $\begin{array}{l}\text { Endêmicos } \\
\text { (sem SK) }\end{array}$ & $\begin{array}{l}\text { Whitby, et al., } \\
2004\end{array}$ \\
\hline B1 & A5 & UG_15 & GU238300.1 & Uganda & Endêmico & $\begin{array}{c}\text { Tornesello, et al., } \\
2010\end{array}$ \\
\hline B2 & B3 & UG_18 & GU238306.1 & Uganda & Endêmico & $\begin{array}{c}\text { Tornesello, et al., } \\
2010\end{array}$ \\
\hline B2 & B3 & UG_80 & GU238307.1 & Uganda & Endêmico & $\begin{array}{c}\text { Tornesello, et al., } \\
2010\end{array}$ \\
\hline B1 & $\mathrm{NI}$ & UG_107 & GU238200.1 & Uganda & Endêmico & $\begin{array}{c}\text { Tornesello, et al., } \\
2010\end{array}$ \\
\hline B3 & $\mathrm{NI}$ & UG_110 & GU238305.1 & Uganda & Endêmico & $\begin{array}{c}\text { Tornesello, et al., } \\
2010\end{array}$ \\
\hline A3 & A3 & GR_93 & GU238298.1 & Grécia & latrogênico & $\begin{array}{c}\text { Tornesello, et al., } \\
2010\end{array}$ \\
\hline * & $\mathrm{F}$ & KE_234 & GU238311.1 & Quênia & SK-AIDS & $\begin{array}{c}\text { Tornesello, et al., } \\
2010\end{array}$ \\
\hline$A / C$ & C & US_215 & GU238297.1 & EUA & SK-AIDS & $\begin{array}{c}\text { Tornesello, et al., } \\
2010\end{array}$ \\
\hline A & C3 & IT_220 & GU238294.1 & Itália & SK-AIDS & $\begin{array}{c}\text { Tornesello, et al., } \\
2010\end{array}$ \\
\hline B1 & C & KE_230 & GU238304.1 & Quênia & SK-AIDS & $\begin{array}{c}\text { Tornesello, et al., } \\
2010\end{array}$ \\
\hline C & B1 & UG 64 & GU238302.1 & Uganda & Endêmico & $\begin{array}{c}\text { Tornesello et al., } \\
2010\end{array}$ \\
\hline B1 & B1 & UG 65 & GU238303.1 & Uganda & Endêmico & $\begin{array}{c}\text { Tornesello et al., } \\
2010\end{array}$ \\
\hline B2 & A5 & KE_233 & GU238310.1 & Quênia & SK-AIDS & $\begin{array}{c}\text { Tornesello et al., } \\
2010\end{array}$ \\
\hline
\end{tabular}




\subsection{Análise de Recombinantes}

As análises de recombinação foram feitas através de dois programas distintos: SIMPLOT em sray.med.som.jhmi.edu/SCRoftware/simplot (Lole et al., 1999) e programa RDP em http://darwin.uvigo.es/rdp/rdp.html (Martin et al., 2010).

\subsection{Mutações sinônimas e não sinônimas}

A ocorrência de mutações sinônimas (S) e não sinonimas (N) foram avaliadas ao longo das sequências do locus K1 e K12 através do sítio de domínio público http://www.datamonkey.org (Sergei ei al., 2005), com o uso do método SLAC (Single Likelihood Ancestral Counting). O método baseia-se inicialmente em uma reconstrução filogenética pelo método neighbor joining. Após isso, é realizada a contagem de mutações sinônimas por sitio sinônimo, e mutações não sinônimas por sitio não sinônimo. Com essas informações, uma análise estatística simples é feita para averiguar se há ou não diferença estatística entre os valores. Ainda, o estado ancestral de cada posição (aminoácido) é reconstruido com base na informação filogenética disponível, e a presença do novo estado em dada sequência é determinada como sendo apomorfia ou sinapomorfia. Assim, a pressão seletiva não é só estimada para a sequência como um todo, mas para cada codon da proteína.

No caso de restrições funcionais e estruturais, espera-se encontrar um menor número de variações nos sítios não sinônimos em relação aos sinônimos $(\mathrm{dN}<\mathrm{dS}$ ou $\mathrm{dN} / \mathrm{dS}<1$ ), indicando seleção negativa purificadora. Por outro lado, na presença de seleção positiva, ou diversificadora, espera-se encontrar um número maior de variações nos sítios não sinônimos ( $d N>d S$ ou dN/dS >1). 


\subsection{Análise de Polimorfismos de um Único Nucleotídeo - SNP (Single Nucleotide Polymorphisms)}

$\mathrm{A}$ analise de variabilidade do locus $\mathrm{K} 12$ abrangeu a região contida entre os nucleotídeos 117417 a 118055, com base no genoma de referência do GenBank U75698 (Chang, et al., 1994), originado de uma linhagem celular denominada BC-1, de linfoma de efusão primária de paciente co-infectado por HIV e HHV-8. Foram analisadas as sequências de DNA de HHV-8 do estudo atual e ainda de 20 exemplares do GenBank (listados na Tabela 5), os quais foram provenientes de isolados de HHV-8 obtidos de lesões de sarcoma de Kaposi Clássico, endêmico e epidêmico durante a era pré e pós HAART e de indivíduo assintomático do Equador.

Destacamos as duas regiões codificadoras de microRNA do locus K12 denominadas miR-K12-12 e miR-K12-10 (cujas sequências foram consultadas no banco de dados VIRmiRNA, geradas a partir de pesquisa experimental de miRNA viral e seus alvos (http://www.crdd.osdd.net/servers/virmirna): miR12-10a (117991117970), miRNA12-10a* (118031-118010), miR12-10b (117989-117970), miR12-12 (117713-117692), miR12-12 (117951-117929).

\subsection{Análise Estatística}

Para a comparação entre os grupos 1 e 2 , em relação as suas características, definição dos genótipos de HHV-8 e ausência ou presença dos SNPs foram utilizados o teste do qui quadrado e o teste exato de Fisher. 
O desenvolvimento do estudo permitiu selecionar trinta e quatro $(n=34)$ indivíduos infectados por HIV com SK (grupo 1 - SK) e quarenta e um ( $n=41$ ) sem SK (grupo 2 - nSK). Esse número foi decorrente das amostras que tiveram sequências de DNA de HHV-8 isoladas de CMSP ou saliva, conforme os resultados descritos nos itens a seguir. A Figura 9 apresenta o esquema do estudo para a seleção dos setenta e cinco $(n=75)$ indivíduos cuja a variabilidade genética dos loci da ORF K1 e ORF K12 do genoma do HHV-8 foi investigada.

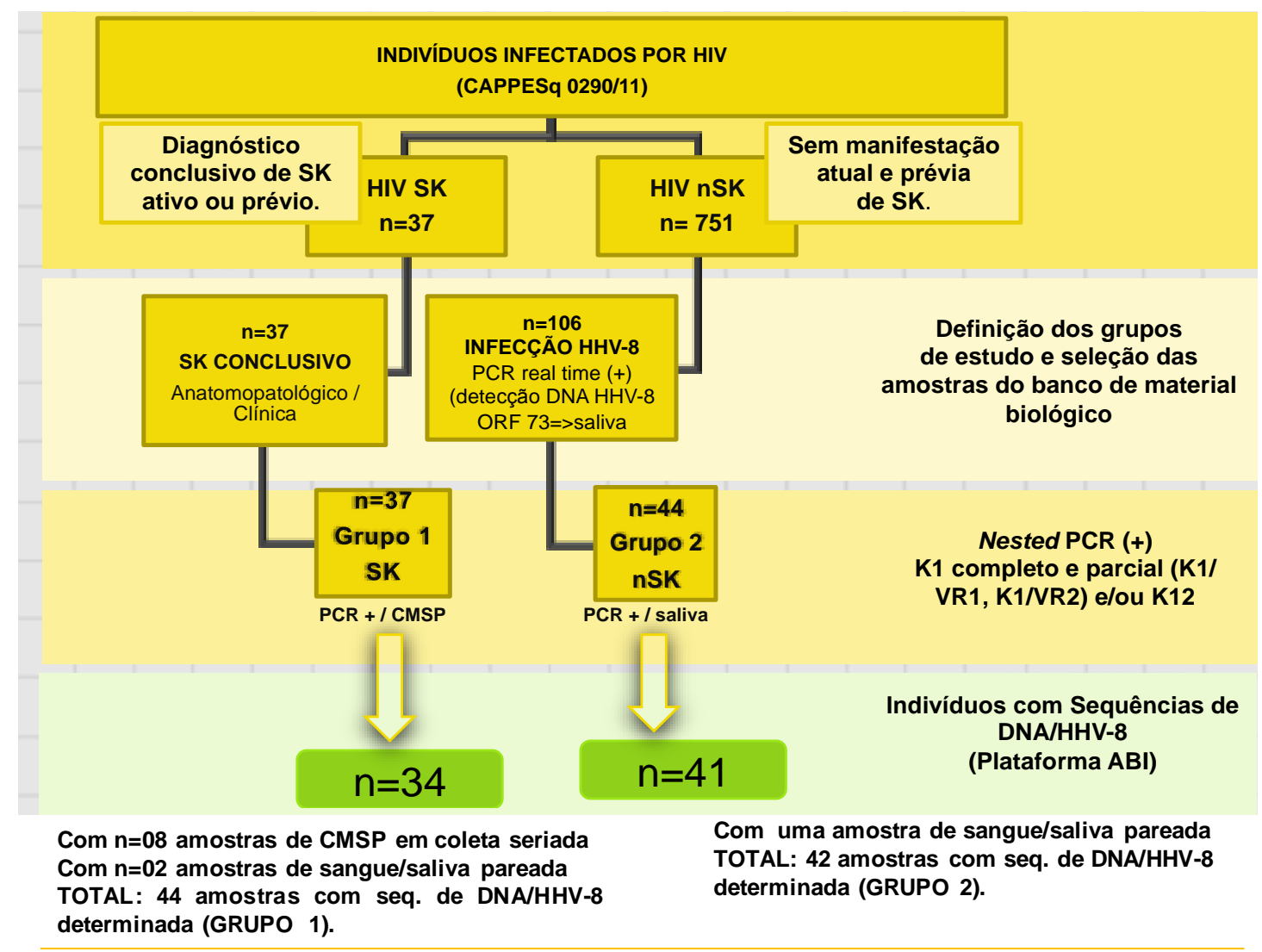

Figura 9 - Seleção dos 75 indivíduos infectados por HIV, com SK (grupo 1, n=34) e sem SK (grupo 2, $n=41$ ). As sequências de DNA/HHV-8 dos loci da ORF $\mathrm{K} 1$ e/ou ORF $\mathrm{K} 12$ foram obtidas pela plataforma $\mathrm{ABI}$, método de Sanger. 


\subsection{Avaliação dos produtos de PCR e seleção das amostras de DNA/HHV-8 positivas}

Obteve-se $100 \%$ de amostras positivas por meio da PCR de beta-globina, demonstrando a viabilidade do DNA das amostras.

A presença dos fragmentos de DNA/HHV-8 (da ORF K1 ou K12) na revelação por eletroforese em gel indicou a positividade do produto da nested PCR em amostras biológicas provenientes de 37 indivíduos do grupo 1-SK e de 44 indivíduos do grupo 2-nSK.

\subsubsection{Avaliação dos Fragmentos de DNA de HHV-8 da ORF K1 e ORF K12}

A Figura 10 apresenta o padrão de positividade das amostras pela presença dos fragmentos de $867 \mathrm{pb}$ (ORF K1 completo), $386 \mathrm{pb}$ (K1/VR1), $375 \mathrm{pb}$ (K1/VR2) e $752 \mathrm{pb}, 646 \mathrm{pb}$ e $407 \mathrm{pb}$ (ORF K12). As amostras de DNA de CMSP (grupo 1-SK) e saliva (grupo 2 -nSK) foram submetidas à amplificações para as 2 regiões do genoma de HHV-8: ORF K1 (completo e parcial - K1/VR1 e K1/VR2) e ORF K12. 

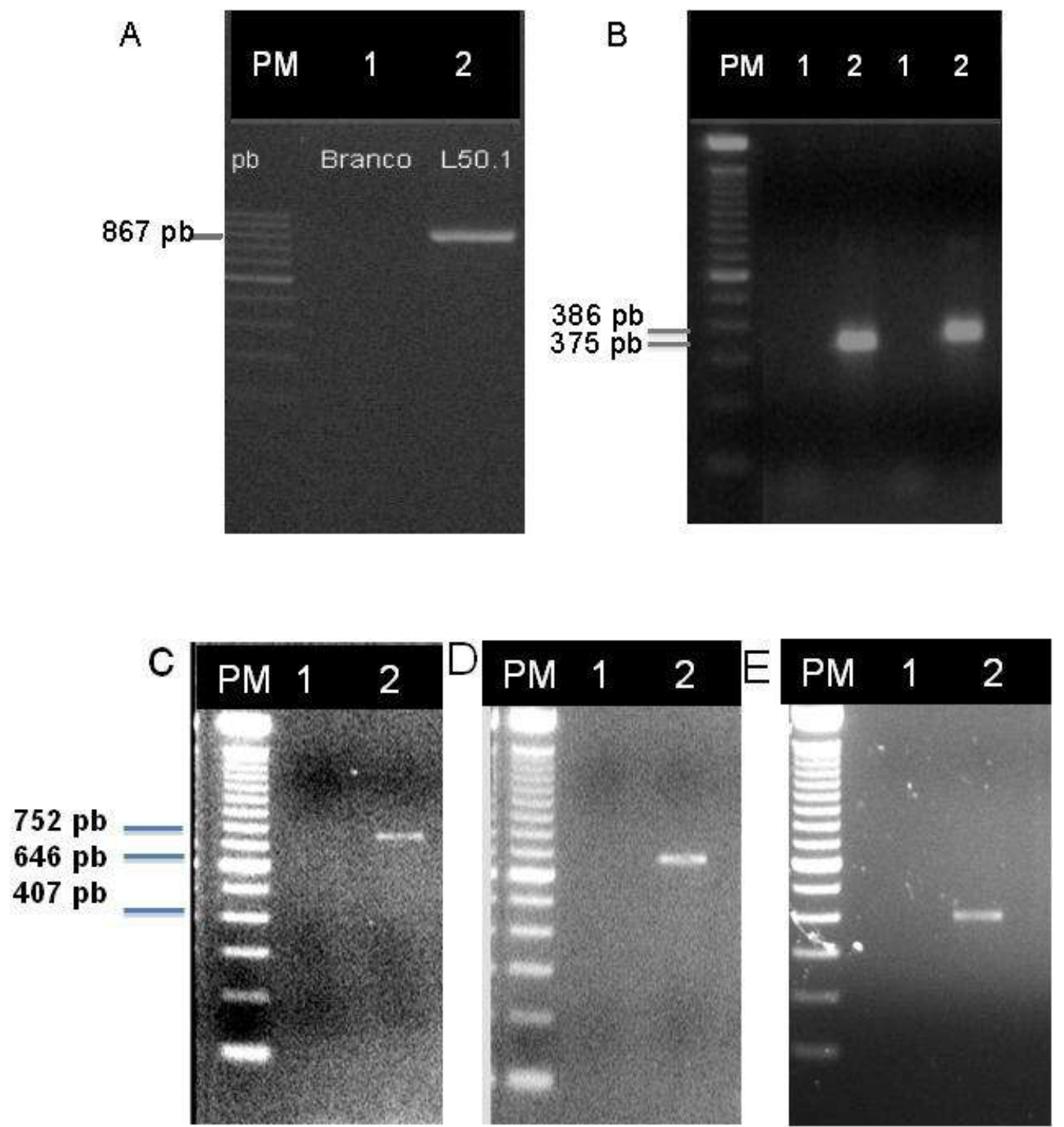

Figura 10 - Padrão de migração por eletroforese em gel de agarose $1,5 \%$ de fragmentos de DNA alvo de HHV-8. Fragmentos de $867 \mathrm{pb}(\mathrm{A}), 386 \mathrm{pb}$ e $375 \mathrm{pb}(\mathrm{B})$ referente aos produtos do nested PCR para ORF K1 completa, VR1 e VR2, respectivamente, obtidos no segundo round de amplificação. Fragmento de 752 pb (C) obtido por nested PCR para a ORF K12 no primeiro round; e 646 pb (D) e 407 pb (E) obtidos após segundo round, respectivamente. À esquerda, o padrão de peso molecular (100 pb); 1. Amostra negativa; 2. Amostra positiva. 


\subsubsection{Semi-quantificação, purificação do produto de PCR e padrão de qualidade das sequências de DNA obtidas}

A Figura 11 apresenta o padrão de qualidade de um exemplar de fragmento de DNA de HHV-8 purificado, para um total de $20 \mathrm{ng}$ do produto de PCR purificado $(4 \mu \mathrm{L})$ que foi utilizado para a reação de sequenciamento de DNA.

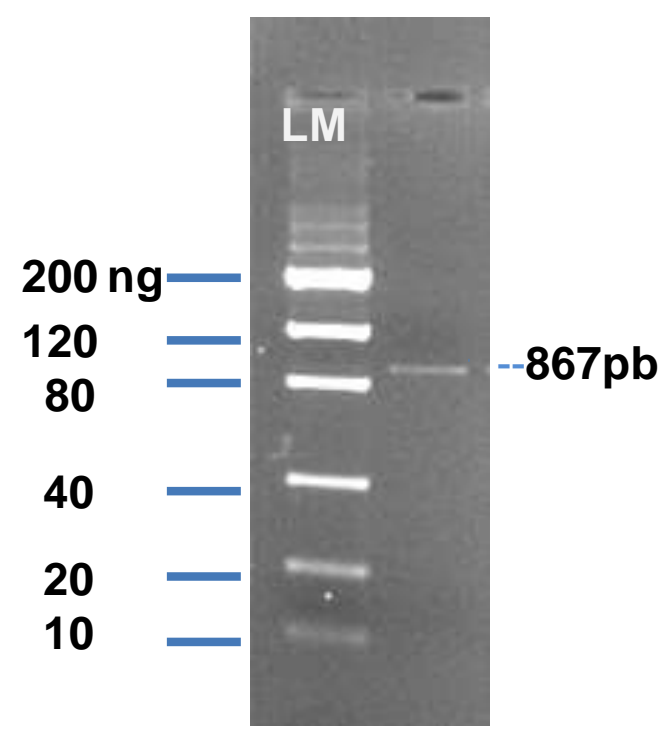

Figura 11 - Semi-quantificação de DNA com uso de marcador de massa molecular (LM, à esquerda) Low DNA Mass Ladder (Gibco) após eletroforese em gel de agarose $1,5 \%$ sob transiluminação ultravioleta. Note o fragmento de $867 \mathrm{pb}$ (à direita) equivalente a $10 \mathrm{ng}$ do produto de PCR purificado $(2 \mu \mathrm{L})$.

\subsection{Indivíduos infectados por HIV com diagnóstico conclusivo de SK}

\subsubsection{Sequências de DNA/HHV-8 dos loci da ORF K1 e ORF K12 no grupo 1-SK}

Trinta e três dos trinta e sete (33/37) indivíduos infectados por HIV com SK tiveram sua sequência de DNA/HHV-8 da ORF K1 determinada com qualidade. Treze $(n=13)$ indivíduos tiveram a sequência de DNA viral determinada com 
qualidade tanto da ORF K1 quanto da ORF K12 e apenas um ( $\mathrm{n}=01)$ indivíduo teve sua sequência viral exclusivamente determinada para a ORF K12 (K1 negativa e K12 positiva).

Em suma, foram selecionados 33 indivíduos com suas sequências de HHV-8 determinadas com qualidade para o locus $\mathrm{K} 1$ e 1 indivíduo com sequência viral determinada exclusivamente para a ORF K12, totalizando 34 indivíduos com suas sequências de DNA de HHV-8 (grupo 1).

\subsection{Indivíduos infectados por HIV sem histórico de SK}

\subsubsection{Definição da infecção por HHV-8}

As amostras de saliva obtidas dos 751 indivíduos sem histórico de SK foram primeiramente submetidas à triagem para identificação dos indivíduos co-infectados HIV e HHV-8 para posterior genotipagem do HHV-8. Cento e seis (106/751) foram definidos como infectados por HHV-8, conforme a detecção de DNA positiva da ORF 73 do HHV-8 na amostra de saliva por PCR em tempo real. A curva de referência baseada na diluição seriada de plasmídeo pGEX com inserto da ORF73 e os valores de $\mathrm{C}_{\mathrm{T}}$ estão apresentados na Figura 12. O log da carga viral do HHV-8 na saliva variou entre 0,5 a 6,82 (4 a 6.605.179 cópias de HHV-8 por $\mu g$ de DNA). A Figura 13 apresenta a distribuição do número de indivíduos co-infectados por HIV e HHV-8 de acordo com a categoria da carga viral de HHV-8/ORF 73 na saliva. 
A



B



Figura 12 - A. Perfil de amplificação da ORF 73 HHV-8 por PCR em tempo real. As amostras do plasmídeo/ORF73 diluído (triplicatas), contendo $10^{\circ}$ a $10^{6}$ cópias de plasmídeos, que foram utilizadas para a construção da curva de referência. A quantificação do número de cópias de DNA/HHV-8 foi estabelecida de acordo com a concentração total de DNA de cada amostra de saliva em $\mu \mathrm{g}$ de DNA. O gráfico apresenta a relação entre o número de ciclos de amplificação inicial de DNA $\left(\mathrm{C}_{\mathrm{T}}\right)$ versus o Delta $\mathrm{Rn}$, com o estabelecimento da linha de base ou limiar de positividade (linha horizontal preta, linha threshold), segundo Software ABI PRISM 7300. As amostras controles negativas foram representadas pelos ruídos abaixo da linha threshold. B. Curva padrão relacionando o número de ciclos de amplificação inicial de DNA da ORF $73\left(\mathrm{C}_{\mathrm{T}}\right)$ e a diluição do plasmídeo (log). Software do ABI PRISM 7300. Regressão linear da curva padrão com $R^{2}=0,991$

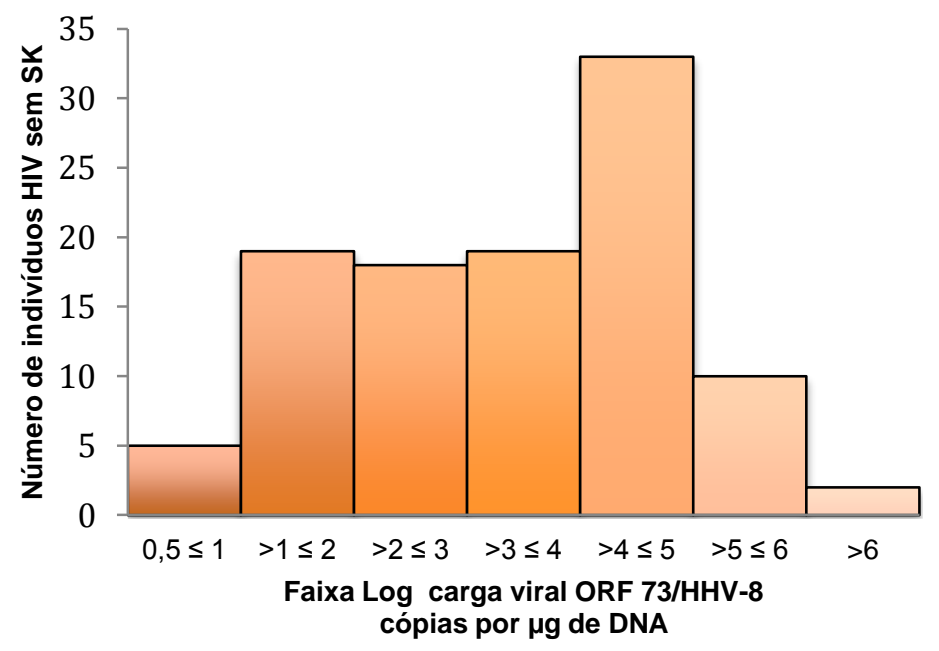

Figura 13 - Distribuição do número de indivíduos co-infectados HIV e HHV-8 $(n=106)$, conforme categoria de carga viral de HHV-8/ORF 73 - log (faixa de $>0,5$ a $\leq 1,1$ a $\leq 2,2 \leq 3,3 \leq 4,4 \leq 5,5$ a $\leq 6$, $>6$ cópias por $\mu g$ de DNA), para composição do grupo 2 - nSK. 


\subsubsection{Sequências de DNA/HHV-8 dos loci da ORF K1 e ORF K12 no grupo 2-nSK}

A detecção dos respectivos fragmentos de DNA da ORF K1 e/ou K12 do HHV8 por nested PCR foi obtida na saliva de quarenta e quatro dos cento e seis (44/106) indivíduos co-infectados HIV e HHV-8.

Dos 106 individuos, 37 foram positivos na PCR para a ORF K1 e 28 para a ORF K12. Dos positivos para a ORF K1, 34/37 tiveram sua sequência de DNA/HHHV-8 determinada com qualidade. Todos os 28 indivíduos positivos para a ORF K12 (28/106) tiveram sua sequência determinada com qualidade, sendo que sete (7/28) tiveram sequência de DNA exclusiva para o locus K12.

Em suma, foram selecionados 34 indivíduos com sequência da ORF K1 determinada e adicionalmente, 7 indivíduos com sequência exclusiva do locus K12, totalizando quarenta e um $(n=41)$ indivíduos com sequência de DNA/ HHV-8 e pertencente ao grupo 2 .

\subsection{Descrição geral das características demográficas e laboratoriais dos grupos de estudo}

A média de idade do grupo 1- SK foi de 38,7 anos e do grupo 2 - nSK foi de 43,5 anos na ocasião do estudo. No grupo 1 - SK, a idade variou de 23 anos a 65 anos e do grupo 2 - nSK foi de 24 anos a 62 anos. Houve maior número de casos na faixa etária inferior a 40 anos no grupo 1 do que no grupo $2(p=0,01)$. Todavia, a maioria dos indivíduos do grupo 2 era pertencente a faixa etária inferior a 40 anos de idade, igualmente ao grupo 1, na ocasião de maior incidência de SK (1998/1999) e até o momento não apresentaram SK. 
A cor branca e o sexo masculino foram predominantes em ambos os grupos. Dos 75 indivíduos, 55 foram registrados como brancos (73,3\%) e 69 foram do sexo masculino (92\%), embora sem diferença estatística em relação a cor de pele $(p=0,83)$ e ao gênero $(p=0,65)$ entre os grupos 1 e 2 .

Houve maior prorporçao de indivíduos HSH no grupo 2 - nSK $(63,41 \%)$ do que no grupo 1 -SK, embora a diferença não foi estatísticamente significativa $(p=0,30)$.

A frequência de indivíduos com contagem de CD4+ em níves relacionados a maior suscetibilidade à doenças oportunistas $\left(<250\right.$ células $\left./ \mathrm{mm}^{3}\right)$ foi maior no grupo 1 - SK do que 2 - nSK (p=0,02). Um total de 70,7\% dos indivíduos sem SK apresentaram nível de CD4+ maior ou igual a 300 células por $\mathrm{mm}^{3}$. No entanto, um total de nove indivíduos (26,5\%) do grupo 1 - SK, a despeito da presença de SK, apresentaram contagem de CD4+ maior ou igual a 300 células por $\mathrm{mm}^{3}$, enquanto sete indivíduos $(17,1 \%$ ) sem SK (grupo 2 - nSK) apresentaram contagem de CD4+ menor que 250 células por $\mathrm{mm}^{3}$, mas essa avaliação foi apenas pontual.

No grupo 1 - SK, todos os indivíduos foram submetidos a terapia antirretroviral (ART), apenas um caso não houve registro sobre a informação do uso de ART. No grupo 2 - nSK, somente 2,4\% não foram submetidos ao ART e não houve registro da data de início do uso de ART em 27\% desses indivíduos.

Dos registros sobre os níveis de carga viral de HIV na ocasião da admissão do estudo, 20 registros foram obtidos no grupo 1 e 35 no grupo 2. Não houve diferença entre o log da média da carga viral de HIV entre o grupo 1 - SK (média 3,93) e grupo 2 - nSK (média 3,73). Nos grupos 1 - SK e 2 - nSK, os registros sobre o log da carga viral de HIV variaram em torno de 2 a 5 cópias (log). No grupo 2 - nSK, 15 casos apresentaram carga viral de HIV indetectável.

Os dados demográficos e laboratóriais dos indivíduos infectados por HIV do grupo SK (grupo 1) e nSK (grupo 2), dos quais as sequências de DNA de HHV-8 foram obtidas para o estudo da variabilidade genética, foram sumarizados na Tabela 6 . 
Tabela 6 - Dados demográficos e laboratoriais dos 75 indivíduos infectados por HIV grupo 1 - SK e grupo 2 - nSK

\begin{tabular}{|c|c|c|c|c|c|}
\hline \multirow[t]{2}{*}{$\begin{array}{c}\text { Indivíduos HIV } \\
n=75\end{array}$} & \multirow[b]{2}{*}{ Variantes } & \multicolumn{2}{|c|}{$\begin{array}{c}\text { Grupo 1-SK } \\
(n=34)\end{array}$} & \multicolumn{2}{|c|}{$\begin{array}{c}\text { Grupo 2-nSK } \\
(n=41)\end{array}$} \\
\hline & & $\mathrm{n}$ & $\%$ & $\mathrm{n}$ & $\%$ \\
\hline \multirow[t]{3}{*}{ *Grupo etário (anos) } & $<40$ & 22 & 64,7 & 16 & 39,0 \\
\hline & $>$ ou $=40$ & 10 & 29,4 & 25 & 61,0 \\
\hline & NR & 2 & 5,9 & 0 & 0,0 \\
\hline \multirow[t]{2}{*}{ Sexo } & Masc & 31 & 91,2 & 38 & 92,7 \\
\hline & Fem & 3 & 8,8 & 3 & 7,3 \\
\hline \multirow[t]{3}{*}{ Cor } & branco & 23 & 67,6 & 32 & 78,0 \\
\hline & Não branco & 7 & 20,6 & 8 & 19,5 \\
\hline & NR & 4 & 11,7 & 1 & 2,4 \\
\hline \multirow[t]{3}{*}{ Risco } & $\mathrm{HSH}$ & 14 & 41,17 & 26 & 63,41 \\
\hline & Outros & 15 & 44,12 & 15 & 36,59 \\
\hline & NR & 5 & 14,70 & 0 & 0 \\
\hline${ }^{*}$ Categorias CD4+ & $<250$ & 15 & 44,1 & 7 & 17,1 \\
\hline \multirow[t]{3}{*}{ (células/mm³) } & $\geq 250 \mathrm{a}<300$ & 3 & 8,8 & 4 & 9,8 \\
\hline & $\geq 300$ & 9 & 26,5 & 29 & 70,7 \\
\hline & NR & 7 & 20,6 & 1 & 2,4 \\
\hline Carga viral HIV & $>$ ou $=3$ & 13 & 38,2 & 16 & 31,7 \\
\hline \multirow[t]{3}{*}{ (log cópias/mL) } & $<3$ & 7 & 20,6 & 4 & 3,8 \\
\hline & Indetect. & 0 & 2,3 & 15 & 36,6 \\
\hline & NR & 14 & 38,2 & 6 & 14,6 \\
\hline
\end{tabular}

$\overline{\mathrm{HSH}}=$ homossexual masculino, excetuando bissexual. Outros = heterossexuais, parceiro HIV, profissional do sexo, risco transfusional, usuário de drogas injetáveis (UDI), bissexual. Masc e Fem = abreviações do gênero Masculino e Feminino, respectivamente. Não branco = registrados como mulato, negro, pardo e amarelo. Indetect. = Indetectável. NR = dado Não Registrado. *Diferença estatística significativa, $p<0,05$. Os números de NR foram incluídos no cálculo das porcentagens das variantes, mas foram excluídos na análise estatística.

\subsubsection{Homens que fazem sexo com homens (HSH)}

A maior proporção de homossexuais masculinos no grupo 2-nSK do que no grupo 1-SK foi uma tendência, embora não siginificativa estatiticamente. No grupo 1SK, a proporção de bissexuais foi maior, sem diferença estatística conforme Figura 14 e Tabela 7. 

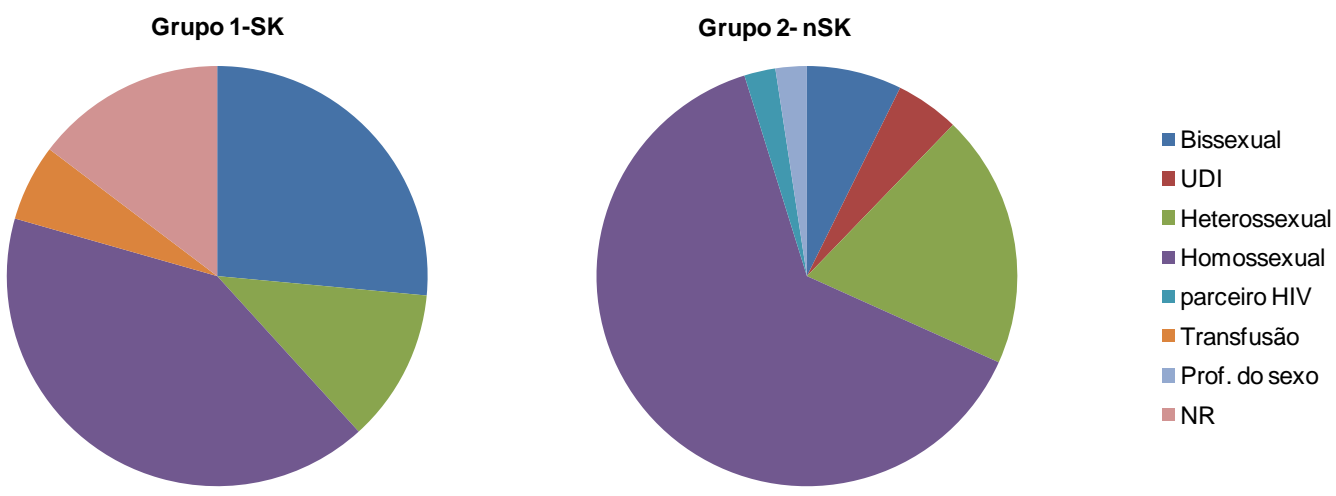

Figura 14 - Proporção das categorias risco de adquirir HIV. Note maior proporção da categoria bissexual no grupo 1 - SK e maior proporção de homossexuais e heterossexuais no grupo $2-n S K$.

Tabela 7 - Distribuição e frequência das diferentes categorias de risco de transmissão para adquirir HIV entre o grupos com e sem SK

\begin{tabular}{ccccccc}
\hline & \multicolumn{2}{c}{ Grupo 1-SK } & \multicolumn{2}{c}{ Grupo 2-nSK } & \multicolumn{2}{c}{ Total } \\
\hline Risco HIV & $\mathbf{n}$ & $\%$ & $\mathbf{n}$ & $\%$ & $\mathbf{n}$ & $\%$ \\
\hline Bissexual & 9 & 26,5 & 3 & 7,3 & 12 & 16,0 \\
UDI & 0 & 0,0 & 2 & 4,9 & 2 & 2,7 \\
\hline Heterossexual & 4 & 11,8 & 8 & 19,5 & 12 & 16,0 \\
\hline Homossexual & 14 & 41,2 & 26 & 63,4 & 40 & 53,3 \\
\hline parceiro HIV & 0 & 0,0 & 1 & 2,4 & 1 & 1,3 \\
\hline Transfusão & 2 & 5,9 & 0 & 0,0 & 2 & 2,7 \\
\hline Prof. do sexo & 0 & 0,0 & 1 & 2,4 & 1 & 1,3 \\
NR & 5 & 14,7 & 0 & 0,0 & 5 & 6,7 \\
\hline Total & 34 & 100,0 & 41 & 100 & 75 & 100,0 \\
\hline
\end{tabular}

$\mathrm{UDI}=$ usuário de drogas injetáveis. $\mathrm{NR}=$ Não Registrado. Prof. sexo = profissional do sexo. Homossexual $=$ homossexual masculino. $\mathrm{n}=$ número de casos.

\subsubsection{Tempo de infecção por HIV e aids}

O tempo (em anos) do diagnóstico da infecção por HIV, aids e SK foi medido até a data da coleta do material biológico (sangue ou saliva) no grupo 1-SK e grupo 2-nSK. A distribuição do número de indivíduos pertencentes a cada categoria de 
tempo (menor ou igual a 1 ano, entre 1 a 6 anos e entre 6 a 12, e maior que 12 anos) do diagnóstico da infecção por HIV, aids e SK foi apresentada na Tabela 8.

No grupo 1 - SK, nota-se que a maioria dos indivíduos teve o diagnóstico da infecção por HIV e/ou aids na categoria de tempo menor ou igual a 1 ano, que marca a ocasião da admissão dos indivíduos com sarcoma de Kaposi nos meados da era HAART em 1998 ou1999 para o estudo.

No grupo 2 - nSK, somente oito dos indivíduos sem SK tiveram o diagnóstico da infecção por HIV a menos de 6 anos (8/40). Os registros obtidos revelaram que a maioria deles apresentou longo tempo de infecção por HIV (30/40) ou de diagnóstico de aids (16/24), considerando as categorias de $\geq 6$ a $\leq 12$ anos e $\geq 12$ anos, sendo que nove deles não tiveram aids e oito não tiveram registro desse dado (NR).

Tabela 8 - Distribuição do número de indivíduos infectados por HIV, Grupo 1-SK e grupo 2-nSK, de acordo com a categoria de Intervalo de tempo entre a data de admissão no protocolo de estudo (data da coleta do material biológico) e o diagnóstico da infecção por HIV, aids e SK.

\begin{tabular}{|c|c|c|c|}
\hline \multirow[t]{2}{*}{ Tempo (anos) } & \multicolumn{3}{|c|}{ Número de casos (n) } \\
\hline & HIV & AIDS & SK \\
\hline \multicolumn{4}{|c|}{ Grupo 1 - SK } \\
\hline$\leq 1$ ano & 22 & 23 & 28 \\
\hline $1 \mathrm{a} \leq 6$ anos & 9 & 7 & 5 \\
\hline 6 a $\leq 12$ anos & 2 & 1 & 0 \\
\hline$>12$ anos & 0 & 0 & 0 \\
\hline NR & 1 & 3 & 1 \\
\hline Total & 34 & 34 & 34 \\
\hline \multicolumn{4}{|c|}{ Grupo 2 - nSK } \\
\hline$\leq 1$ ano & 2 & 3 & - \\
\hline$>1$ a $\leq 6$ anos & 8 & 5 & - \\
\hline$>6 \mathrm{a} \leq 12$ anos & 21 & 11 & - \\
\hline$>12$ anos & 9 & 5 & - \\
\hline NR ou Obs* & 1 & $17^{*}$ & - \\
\hline Total & 41 & 41 & - \\
\hline
\end{tabular}




\subsection{Anáise filogenética baseada nas sequências de DNA do HHV-8 dos grupos com e sem SK}

\subsubsection{Avaliação do desempenho dos diferentes primers do locus K1 na análise de genótipos}

Escolhemos utilizar primers que abrangessem o locus K1 completo além da sequências parciais, visto que na análise do alinhamento de sequências de HHV-8 de referência, notamos que há divergência de nucleotídeos na região dos primers VR1 e VR2, especialmente VR2A-Forward e VR2B-Reverse (conforme mostra a Figura 15), o que pode prejudicar a amplificação de um dado genótipo ou subgenótipo de HHV-8. 
Alinhamento $1^{\underline{a}}$ parte

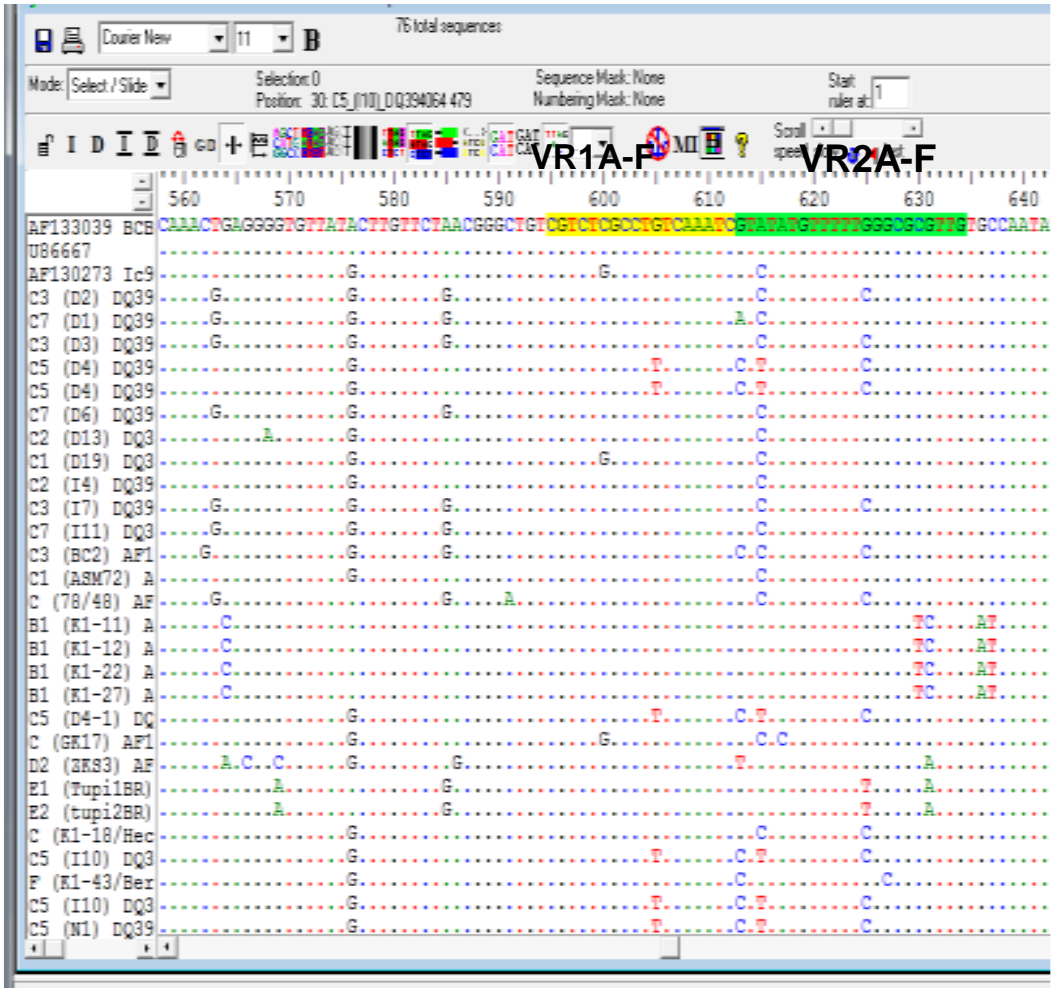

Alinhamento $2^{\underline{a}}$ parte

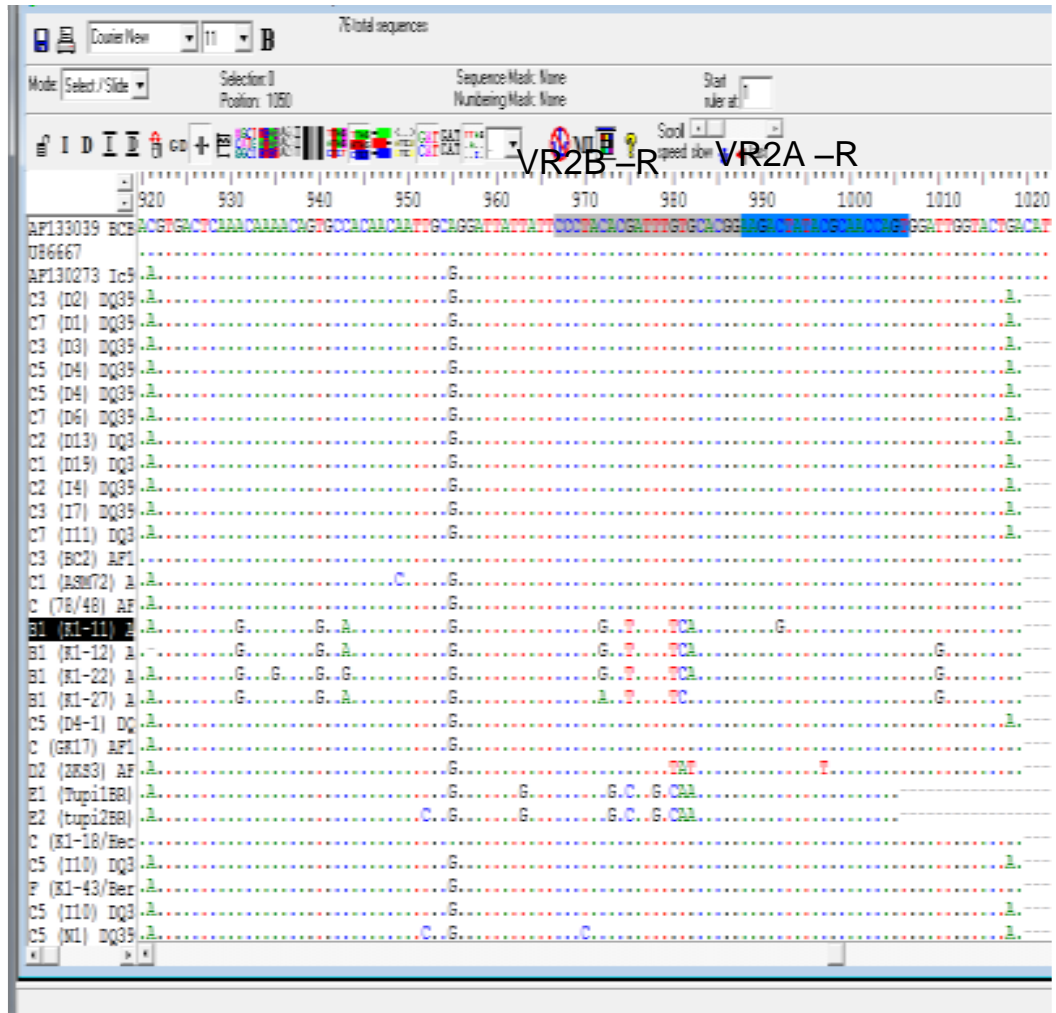

Figura 15 - Apresentação do alinhamento ( $1^{\mathrm{a}}$ e $2^{\mathrm{a}}$ parte) de protótipos de sequência de DNA do locus $\mathrm{K} 1$ do HHV-8 e a área de divergência de nucleotídeos em destaque na região dos primers VR1 A - Forward (amarelo), e VR2A - Forward (verde), VR2B - Reverse (cinza); VR2A - Reverse (azul). 


\subsubsection{Classificaçao filogenética das Sequências de DNA de HHV-8}

As sequências de DNA/HHV-8 do locus $\mathrm{K} 1$ e $\mathrm{K} 12$ dos 75 indivíduos foram submetidas a análises filogenéticas, conforme apresentada nas Figuras 16 e 17.

A reconstrução filogenética a partir de sequências de DNA da região da ORF K1 completa ou parcial K1/VR1 é apresentada na Figura 16 A, e a reconstrução baseada na ORFK1 completa ou parcial K1/VR2, na Figura 16 B. A reconstrução filogenética das sequências de DNA/HHV-8 da ORF K1 no estudo atual permitiu identificar os genótipos ou genótipos A, B, C e F. Os subgenótipos encontrados foram dos intratipos $A 1, A 2, A 4, A 5, B 1, B 2, C 1, C 2, C 3, C 7$ e o intertipo C5. Ambos os intratipos, C3 e B1 foram predominantes em ambos os grupos desse estudo . 


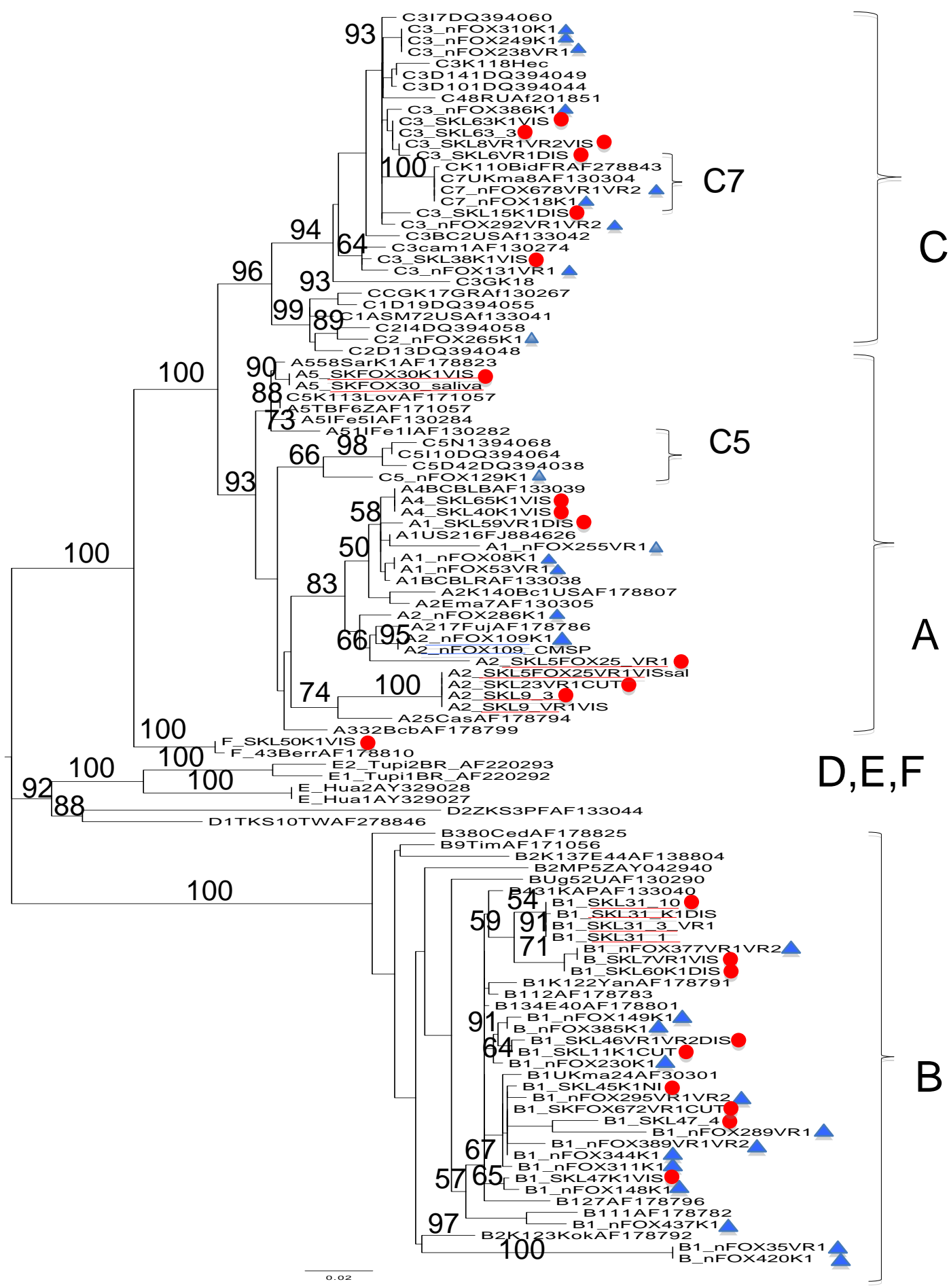

Figura 16 A - Árvore filogenética construída a partir de sequências de DNA do locus K1 completo e parcial (K1/VR1) do HHV-8. Sequências de HHV-8 de trinta e quatro indivíduos infectados por HIV do grupo 1-SK (representadas pelo círculo vermelho) e 41 do grupo 2 - nSK (representadas pelo triângulo azul). Elementos sublinhados em vermelho representam sequências de HHV-8 obtidas de amostras biológicas seriadas do mesmo paciente. Quarenta e oito protótipos foram obtidos do genBank. Nos ramos, bootstrap maior que $50 \%$. Método de neighbor joining. 


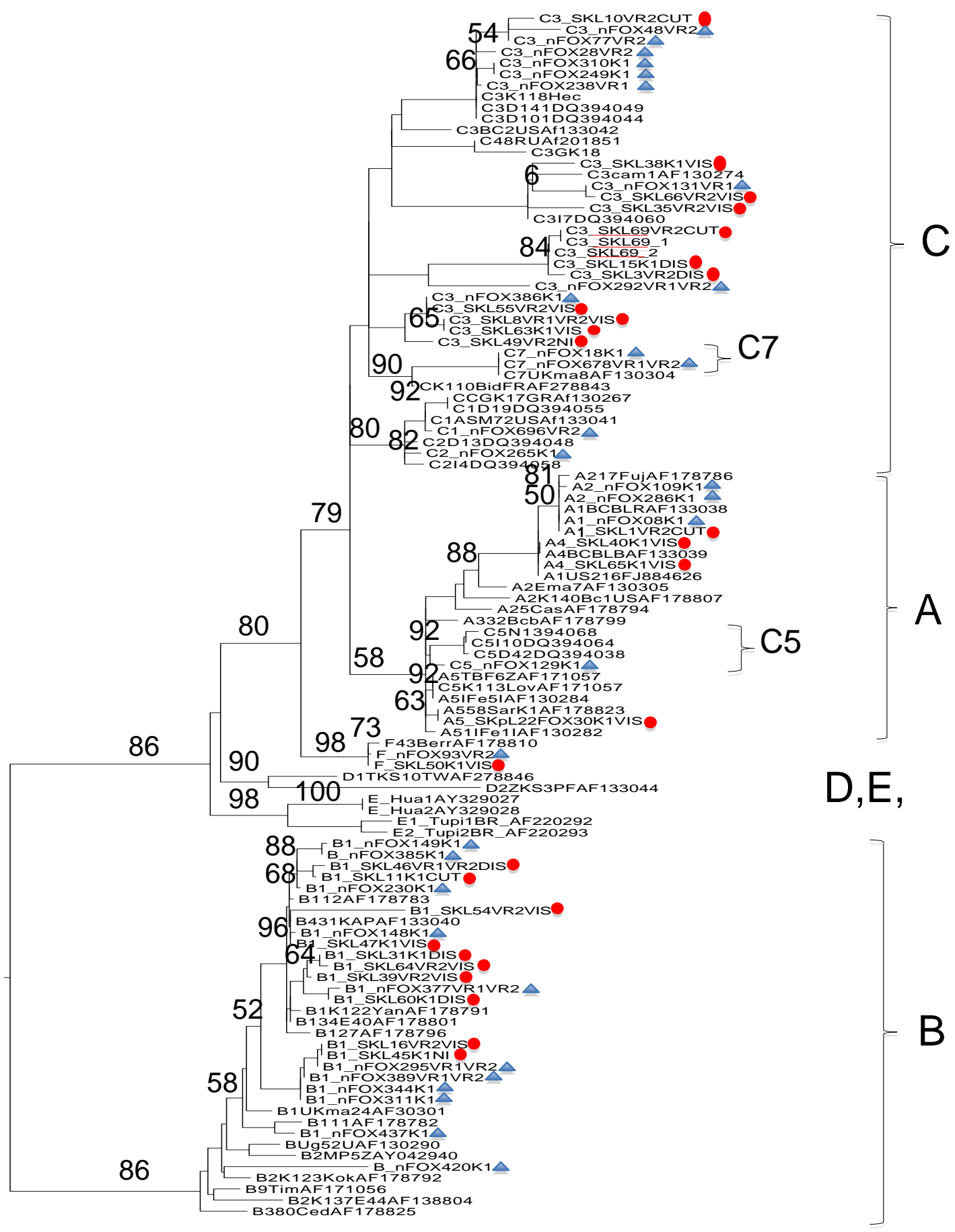

Figura 16 B - Árvore filogenética construída a partir de sequências de DNA do locus K1 completo e parcial (K1/VR2) do HHV-8. Sequências de HHV-8 de trinta e quatro indivíduos infectados por HIV do grupo 1-SK (representadas pelo círculo vermelho) e 41 do grupo 2-nSK (representadas pelo triangulo azul). Elementos sublinhados representam sequências de HHV-8 obtidas em ocasiões ou materais biológicos diferentes do mesmo paciente. Quarenta e oito protótipos foram obtidos do genBank. Nos ramos, bootstrap maior que $50 \%$. Método neighbor joining. 
A Figura 17 apresenta a reconstrução filogenética baseada no locus K12, com 42 sequências de HHV-8, 14 do grupo 1 -SK e 28 do grupo 2 -nSK. A reconstrução filogenética baseada na ORF K12 permitiu a identificação das classes filogenéticas $A / C, B, C$. Não houve separação entre os genótipos $A$ e $C$, conforme pode ser observado. Ainda, baseando-se no locus K12, foram identificados 7 (50\%) grupamento A/C no grupo 1-SK e 17 de A/C (60,1\%) no grupo 2 -nSK.

Observamos 6 casos em que o genótipo do locus $\mathrm{K} 1$ foi diferente daquele obtido no locus K12: no grupo 1 -SK, K12 B e K1 A1, K12 A/C e K1 B1, K12 B e K1 F, K12 B e K1 A4; e no grupo 2 nSK, K12 A/C e K1 B2, K12 A/C e K1 B1. 




Figura 17 - Árvore filogenética construída a partir das sequências de DNA de HHV-8 do locus $\mathrm{K} 12$, sendo as obtidas nesse estudo representadas em círculo vermelho (grupo 1, SK) ou em triângulo azul (grupo 2, nSK). Vinte protótipos obtidos do GenBank. Nos ramos, bootstrap maior que $50 \%$. Método de neighbor joining. A identificação das unidades taxonômicas foi precedida pelo genótipo dado pela análise da ORF K1 e/ou do genótipo da análise da ORF K12. *As chaves indicam a classificação genotípica por meio da ORF K12 (A/C, C e B), e não pela classificação tradicional por meio da ORF K1. 
Conforme sumarizado nos quadros 1 e 2 , cento e sessenta e cinco $(n=165)$ sequências de DNA de HHV-8 foram obtidas de 34 indivíduos infectados por HIV com SK (grupo 1) e 41 sem SK (grupo 2): vinte e três sequências do locus K1 de HHV-8 pertencentes a 67 indivíduos (33 indivíduos do grupo 1-SK e 34 do grupo 2-nSK); e quarenta e duas sequências de HHV-8 do locus K12 pertencentes a 14 indivíduos do grupo 1-SK e 28 do grupo 2-nSK.

O quadro 1 apresenta a listagem dos códigos indivíduais do grupo 1 e das respectivas sequências obtidas das duas regiões do genoma do HHV-8 investigadas (ORF K1 e K12): setenta e duas ( $n=72)$ sequências foram do grupo 1, sendo 14 sequências da ORF K12, 13 da ORF K1 completa e as demais foram da região parcial da ORF K1.

O quadro 2 apresenta a listagem dos códigos indivíduais do grupo 2 e das respectivas sequências da ORF K1 e K12: noventa e três ( $n=93)$ sequências de DNA/HHV-8, sendo 28 sequências da ORF K12, 19 sequências da ORF K1 completa e as demais da região parcial da ORF K1.

Sequências de DNA/HHV-8 exclusivas da ORF K12 foram obtidas em oito casos, sendo um $(n=01)$ do grupo 1 -SK e sete $(n=07)$ do grupo 2 -nSK. 
Quadro 1 - Identificação dos genótipos dos isolados de HHV-8 obtidos a partir dos loci K1 completo (K1) e/ou parciais (K1/VR1, K1/VR2) e/ou K12 de cada um dos indivíduos infectados por HIV do grupo 1 SK.

\begin{tabular}{|c|c|c|c|c|c|c|c|c|c|}
\hline \multirow[b]{3}{*}{ Ordem } & \multirow[b]{3}{*}{ CÓDIGO } & \multirow[b]{3}{*}{ QTD } & \multirow[b]{3}{*}{ Subtipo K1 } & \multirow[b]{3}{*}{ Locus K12 } & \multicolumn{4}{|c|}{$\begin{array}{l}\text { Loci das Sequências DNA/HHV-8 } \\
\qquad(n=72)\end{array}$} & \multirow[b]{3}{*}{ Fonte } \\
\hline & & & & & \multicolumn{2}{|c|}{ K1 Parcial } & \multirow{2}{*}{$\begin{array}{c}\mathrm{K} 1 \\
\text { comp } \\
\mathrm{n}=13\end{array}$} & \multirow{2}{*}{$\begin{array}{l}K 12 \\
n=14\end{array}$} & \\
\hline & & & & & $\begin{array}{l}\text { VR1 } \\
n=24\end{array}$ & $\begin{array}{l}\text { VR2 } \\
n=21\end{array}$ & & & \\
\hline 1 & SKFOX30 & 2 & A5 & NEG & 2 & & & & sal./sg** \\
\hline 2 & SKFOX672 & 1 & B1 & $B$ & & & & & $\mathrm{Sg}$ \\
\hline 3 & SKL1 & 1 & A1 & $B$ & & & & & $\mathrm{Sg}$ \\
\hline 4 & SKL3 & 1 & C3 & $\mathrm{A} / \mathrm{C}$ & & & & & $\mathrm{Sg}$ \\
\hline 5 & SKL5FOX25 & 2 & A2 & NEG & 2 & & & & $\mathrm{sal} / \mathrm{sg}^{* *}$ \\
\hline 6 & SKL6 & 1 & $\mathrm{C} 3$ & NEG & & & & & $\mathrm{Sg}$ \\
\hline 7 & SKL7 & 1 & B1 & NEG & & & & & $\mathrm{Sg}$ \\
\hline 8 & SKL8 & 1 & C3 & NEG & & & & & $\mathrm{Sg}$ \\
\hline 9 & SKL9 & 2 & A2 & NEG & 2 & & & & $\mathrm{Sg}^{*}$ \\
\hline 10 & SKL10 & 1 & C3 & NEG & & & & & $\mathrm{Sg}$ \\
\hline 11 & SKL11 & 1 & B1 & $\mathrm{A} / \mathrm{C}$ & & & & & $\mathrm{Sg}$ \\
\hline 12 & SKL15 & 1 & C3 & $\mathrm{A} / \mathrm{C}$ & & & & & $\mathrm{Sg}$ \\
\hline 13 & SKL16 & 1 & B1 & NEG & & & & & $\mathrm{Sg}$ \\
\hline 14 & SKL31 & 4 & B1 & NEG & 4 & & & & $\mathrm{Sg}^{*}$ \\
\hline 15 & SKL35 & 1 & C3 & NEG & & & & & $\mathrm{Sg}$ \\
\hline 16 & SKL38 & 1 & C3 & NEG & & & & & $\mathrm{Sg}$ \\
\hline 17 & SKL39 & 1 & B1 & NEG & & & & & $\mathrm{Sg}$ \\
\hline 18 & SKL40 & 1 & A4 & NEG & & & & & $\mathrm{Sg}$ \\
\hline 19 & SKL45 & 1 & B1 & B & & & & & $\mathrm{Sg}$ \\
\hline 20 & SKL46 & 1 & B1 & NEG & & & & & $\mathrm{Sg}$ \\
\hline 21 & SKL47 & 2 & B1 & NEG & 2 & & & & $\mathrm{Sg}^{*}$ \\
\hline 22 & SKL49 & 1 & C3 & $\mathrm{A} / \mathrm{C}$ & & & & & $\mathrm{Sg}$ \\
\hline 23 & SKL50 & 1 & $\mathbf{F}$ & $B$ & & & & & $\mathrm{Sg}$ \\
\hline 24 & SKL54 & 1 & B1 & $A / C$ & & & & & $\mathrm{Sg}$ \\
\hline 25 & SKL55 & 1 & C3 & NEG & & & & & $\mathrm{Sg}$ \\
\hline 26 & SKL59 & 1 & A1 & $\mathrm{A} / \mathrm{C}$ & & & & & $\mathrm{Sg}$ \\
\hline 27 & SKL60 & 1 & B1 & NEG & & & & & $\mathrm{Sg}$ \\
\hline 28 & SKL63 & 2 & C3 & $C$ & 2 & & & & $\mathrm{Sg}^{*}$ \\
\hline 29 & SKL64 & 1 & B1 & NEG & & & & & $\mathrm{Sg}$ \\
\hline 30 & SKL65 & 1 & A4 & $B$ & & & & & $\mathrm{Sg}$ \\
\hline 31 & SKL69 & 3 & C3 & NEG & & 3 & & & $\mathrm{Sg}^{*}$ \\
\hline 32 & SK66 & 1 & C3 & NEG & & & & & $\mathrm{Sg}$ \\
\hline 33 & SKL23 & 1 & A2 & $\mathrm{A} / \mathrm{C}$ & & & & & $\mathrm{Sg}$ \\
\hline 34 & SKFOX39 & 1 & NEG & $B$ & & & & & $\mathrm{Sg}$ \\
\hline & TOTAL & 44 & & & & & & & \\
\hline
\end{tabular}

*DNA obtido de coleta seriada de CMSP do mesmo indivíduo.

** DNA obtido de material biológico diferente (sangue/saliva) do mesmo paciente.

QTD - quantidade de amostras coletadas por indivíduo. O número no interior da casela indica o número de amostras seriadas de cada indivíduo ensaiadas para respectiva região do genoma do HHV-8. Os tons de cinza diferenciam a região do genoma do HHV-8 que foi amplificada. O código da amostra definido nesse estudo com prefixo SKL ou SKFOX indica indivíduo do grupo 1 - SK. 
Quadro 2 - Identificação dos genótipos dos isolados de HHV-8 obtidos a partir dos loci K1 completo (K1) e/ou parciais (K1/VR1, K1/VR2) e/ou K12 de cada um dos indivíduos infectados por HIV do grupo 2 nSK.

\begin{tabular}{|c|c|c|c|c|c|c|c|c|c|}
\hline \multirow[b]{3}{*}{ Ordem } & \multirow[b]{3}{*}{ CÓDIGO } & \multirow[b]{3}{*}{ QTD } & \multirow[b]{3}{*}{ Subtipo K1 } & \multirow[b]{3}{*}{ Locus K12 } & \multicolumn{4}{|c|}{$\begin{array}{l}\text { Loci das Sequências de DNA de HHV-8 } \\
n=93\end{array}$} & \multirow[b]{3}{*}{ Fonte } \\
\hline & & & & & \multicolumn{2}{|c|}{ K1 parcial } & \multirow{2}{*}{$\begin{array}{c}\mathrm{K} 1 \\
\text { compl. } \\
\mathrm{n}=19\end{array}$} & \multirow{2}{*}{$\begin{array}{l}\mathrm{K} 12 \\
\mathrm{n}=28\end{array}$} & \\
\hline & & & & & $\begin{array}{l}\text { VR1 } \\
n=24\end{array}$ & $\begin{array}{l}\text { VR2 } \\
\mathrm{n}=22\end{array}$ & & & \\
\hline 1 & nFOX8 & 1 & A1 & $\mathrm{A} / \mathrm{C}$ & & & & & sal. \\
\hline 2 & nFOX18 & 1 & C7 & $\mathrm{A} / \mathrm{C}$ & & & & & sal. \\
\hline 3 & nFOX27 & 1 & NEG & $\mathrm{A} / \mathrm{C}$ & & & & & sal. \\
\hline 4 & nFOX28 & 1 & C3 & NEG & & & & & sal. \\
\hline 5 & nFOX31 & 1 & B1 & $B$ & & & & & sal. \\
\hline 6 & nFOX35 & 1 & B2 & $\mathrm{A} / \mathrm{C}$ & & & & & sal. \\
\hline 7 & nFOX93 & 1 & $F$ & NEG & & & & & sal. \\
\hline 8 & nFOX45 & 1 & NEG & $B$ & & & & & sal. \\
\hline 9 & nFOX48 & 1 & C3 & NEG & & & & & sal. \\
\hline 10 & nFOX53 & 1 & A1 & NEG & & & & & sal. \\
\hline 11 & nFOX58 & 1 & NEG & $\mathrm{A} / \mathrm{C}$ & & & & & sal. \\
\hline 12 & nFOX77 & 1 & C3 & $\mathrm{A} / \mathrm{C}$ & & & & & sal. \\
\hline 13 & nFOX109 & 2 & A2 & NEG & & & 2 & & sal./sg ${ }^{\star \star}$ \\
\hline 14 & nFOX129 & 1 & C5 & $\mathrm{NEG}$ & & & & & sal. \\
\hline 15 & nFOX131 & 1 & C3 & $\mathrm{A} / \mathrm{C}$ & & & & & sal. \\
\hline 16 & nFOX148 & 1 & B1 & NEG & & & & & sal. \\
\hline 17 & nFOX149 & 1 & B1 & $\mathrm{A} / \mathrm{C}$ & & & & & sal. \\
\hline 18 & nFOX230 & 1 & B1 & NEG & & & & & sal. \\
\hline 19 & nFOX238 & 1 & C3 & $\mathrm{A} / \mathrm{C}$ & & & & & sal. \\
\hline 20 & nFOX249 & 1 & C3 & $\mathrm{A} / \mathrm{C}$ & & & & & sal. \\
\hline 21 & nFOX253 & 1 & NEG & $\mathrm{A} / \mathrm{C}$ & & & & & sal. \\
\hline 22 & nFOX263 & 1 & NEG & B & & & & & sal. \\
\hline 23 & nFOX255 & 1 & A1 & $\mathrm{A} / \mathrm{C}$ & & & & & sal. \\
\hline 24 & nFOX265 & 1 & C2 & $\mathrm{A} / \mathrm{C}$ & & & & & sal. \\
\hline 25 & nFOX286 & 1 & A2 & $\mathrm{A} / \mathrm{C}$ & & & & & sal. \\
\hline 26 & nFOX289 & 1 & B1 & $B$ & & & & & sal. \\
\hline 27 & nFOX292 & 1 & C3 & $\mathrm{A} / \mathrm{C}$ & & & & & sal. \\
\hline 28 & nFOX295 & 1 & B1 & NEG & & & & & sal. \\
\hline 29 & nFOX307 & 1 & NEG & $\mathrm{A} / \mathrm{C}$ & & & & & sal. \\
\hline 30 & nFOX310 & 1 & C3 & $\mathrm{A} / \mathrm{C}$ & & & & & sal. \\
\hline 31 & nFOX311 & 1 & B1 & B & & & & & sal. \\
\hline 32 & nFOX377 & 1 & B1 & $B$ & & & & & sal. \\
\hline 33 & nFOX375 & 1 & NEG & $C$ & & & & & sal. \\
\hline 34 & nFOX385 & 1 & B1 & $\mathrm{B}$ & & & & & sal. \\
\hline 35 & nFOX386 & 1 & C3 & NEG & & & & & sal. \\
\hline 36 & nFOX389 & 1 & B1 & $B$ & & & & & sal. \\
\hline 37 & nFOX420 & 1 & B2 & NEG & & & & & sal. \\
\hline 38 & nFOX437 & 1 & B1 & B & & & & & sal. \\
\hline 39 & nFOX678 & 1 & C7 & $\mathrm{C} 7$ & & & & & sal. \\
\hline 40 & nFOX696 & 1 & C1 & $\mathrm{A} / \mathrm{C}$ & & & & & sal. \\
\hline 41 & nFOX344 & 1 & B1 & NEG & & & & & sal. \\
\hline & Total & 42 & & & & & & & \\
\hline
\end{tabular}

** DNA de material biológico diferente (sangue/saliva) do mesmo paciente. Sal= coleta de saliva; - Sg=coleta de sangue; QTD- quantidade de amostras coletadas por indivíduo. O número no interior da casela indica o número de amostras seriadas de cada indivíduo amplificadas para dada região do genoma do HHV-8. Os tons de cinza diferenciam a região do genoma do HHV-8 que foi amplificada. O código da amostra definido nesse estudo com prefixo "nFOX indica indivíduo do grupo 2 - sem SK. 


\subsection{Relação dos genótipos (subtipos) e subgenótipos (intratipos/intertipos) de HHV-8 com as diferentes características dos grupos de estudo.}

\subsubsection{Presença ou não do SK}

A comparação dos genótipos de HHV-8 entre indivíduos do grupo 1-SK com SK e grupo 2-nSK sem SK não apontou diferença estatisticamente significativa ( $p=0,79)$.

No grupo 1 - SK, 24\% foi do subtipo ou genótipo A, 35,3\% dos genótipos ou subtipos B e C. No grupo 2, nSK, 12,2\% foi do genótipo A, 34,1\% dos genótipos B e C. Houve apenas um $(n=01)$ genótipo $F$ em cada grupo. A Tabela 9 apresenta a distribuição dos genótipos de HHV-8 observada entre os indivíduos pertencentes aos grupos aqui estudados.

Quantos aos subgenótipos de HHV-8, houve predomínio dos subgenótipos B1 e C3 em ambos os grupos. Os subgenótipos A4 e A5 foram exclusivos do grupo 1-SK. Os subgenótipos $\mathrm{B} 2, \mathrm{C} 1, \mathrm{C} 2, \mathrm{C} 5$ e $\mathrm{C} 7$ foram presentes exclusivamente no grupo 2-nSK (Tabela 9). 
Tabela 9 - Distribuição do número de indivíduos com e sem SK de acordo com os genótipos (subtipos) e subgenótipos (intertipos/intratipos) de HHV-8.

\begin{tabular}{|c|c|c|c|}
\hline Locus K1 & Grupo 1-SK & Grupo 2-nSK & total \\
\hline Genótipo A & $n=8$ & $n=5$ & $n=13$ \\
\hline A1 & 2 & 3 & 5 \\
\hline A2 & 3 & 2 & 5 \\
\hline A4 & 2 & 0 & 2 \\
\hline A5 & 1 & 0 & 1 \\
\hline Genótipo B & $n=12$ & $n=14$ & $n=26$ \\
\hline B1 & 12 & 12 & 24 \\
\hline B2 & 0 & 2 & 2 \\
\hline Genótipo C & $n=12$ & $n=14$ & $n=26$ \\
\hline C1 & 0 & 1 & 1 \\
\hline $\mathrm{C} 2$ & 0 & 1 & 1 \\
\hline $\mathrm{C} 3$ & 12 & 9 & 21 \\
\hline C7 & 0 & 2 & 2 \\
\hline C5 & 0 & 1 & 1 \\
\hline Genótipo F & $n=1$ & $n=1$ & $n=2$ \\
\hline NEG & $n=1$ & $\mathrm{n}=7$ & $n=8$ \\
\hline TOTAL & $n=34$ & $n=41$ & $n=75$ \\
\hline
\end{tabular}

$\mathrm{NEG}=\mathrm{K} 1$ negativo e $\mathrm{K} 12$ positivo.

Diferença estatística, $p=0,79$.

\subsubsection{Estadio de SK}

Um total de $38,25 \%$ (13/34) tiveram a manifestação não visceral do SK (cutânea indolente, localmente agressiva ou disseminada) e 52,94\% (18/34) apresentaram estadio visceral (estadio IV). Três $(\mathrm{n}=03)$ indivíduos não tiveram registro do estadio do tumor (NR). 
Não houve diferença $(p=0,82)$ entre a distribuição dos genótipos de HHV-8 em relação a forma visceral (estadio IV) e não visceral (estádio I, II, e III) do SK, grupo 1, conforme apresentado na Tabela 10. O genótipo $F$ foi detectado tanto em um indivíduo com a forma visceral do SK $(n=01)$ quanto na ausência de SK (grupo 2$\mathrm{nSK}, \mathrm{n}=01)$.

Tabela 10 - Distribuição dos genótipos (subtipos) de HHV-8 em relação a presença da forma visceral e não visceral no grupo 1 - SK. Comparação com a distribuição dos genótipos de HHV-8 no grupo 2 - nSK.

\begin{tabular}{lllllllll}
\hline Grupos de estudo & \multicolumn{9}{c}{ Genótipos de HHV-8 } & \multirow{2}{*}{ total } \\
\cline { 2 - 7 } & Estadio de SK & A & B & C & F & NEG & \\
\hline Grupo 1-SK & Visceral & 4 & 7 & 6 & 1 & 0 & 18 \\
& Não Vis. & 4 & 4 & 5 & 0 & 0 & 13 \\
& NR & 0 & 1 & 1 & 0 & 1 & 3 \\
Grupo 2-nSK & SK-total & $\mathbf{8}$ & $\mathbf{1 2}$ & $\mathbf{1 2}$ & $\mathbf{1}$ & $\mathbf{1}$ & $\mathbf{3 4}$ \\
\hline Total & nSK-total & $\mathbf{5}$ & $\mathbf{1 4}$ & $\mathbf{1 4}$ & $\mathbf{1}$ & $\mathbf{7}$ & $\mathbf{4 1}$ \\
\hline
\end{tabular}

$\mathrm{NR}$ = dado Não Registrado; NEG=K1 Negativo/K12 positivo. Não Vis. = não visceral. $p=0,82$.

Foi observado que entre os subgenótipos exclusivos do grupo 1, um caso de intratipo A5 de HHV-8 foi presente na forma visceral de SK e os dois casos de intratipo A4 foram presentes na forma visceral e mucocutânea disseminada (Tabela 11).

Tabela 11 - Distribuição dos subgenótipos de HHV-8 de acordo com o estadio de SK.

\begin{tabular}{llccccccccc}
\hline & & \multicolumn{1}{c}{ Subgenótipos de HHV-8 } & \multicolumn{1}{c}{ Grupo 1-SK } & \\
Estadio & & A1 & A2 & A4 & A5 & B1 & C3 & F & NEG & total \\
\hline VIS & & 0 & 2 & 1 & 1 & 7 & 6 & 1 & 0 & 18 \\
Não VIS. & CUT & 1 & 1 & 0 & 0 & 2 & 2 & 0 & 0 & 6 \\
& CUT DISS & 1 & 0 & 1 & 0 & 2 & 3 & 0 & 0 & 7 \\
NR & & 0 & 0 & 0 & 0 & 1 & 1 & 0 & 1 & 3 \\
Total & 2 & 3 & 2 & 1 & 12 & 12 & 1 & 1 & 34 \\
\hline
\end{tabular}

$\mathrm{NR}=$ dado Não Registrado. NEG $=\mathrm{K} 1$ negativo K12 positivo. Não VIS. = não visceral. CUT = mucocutânea. CUT DISS = mucocutânea disseminada. 


\subsubsection{Análises da Evolução Clínica de SK e dos níveis de CD4+}

Dos 25 indivíduos do grupo 1-SK com registros sobre evolução clínica do SK, um total de 10 indivíduos tiveram algum episódio de piora clínica de SK, registrado no período de 1998/1999. Houve alguma diferença $(p=0,054)$ entre os genótipos $A$, B e C de HHV-8 no grupo 1-SK em relação a evolução clínica (piora do quadro clínico de SK), conforme critério de Krown et al., 1989. O genótipo B foi significativamente predominante na condição em que não houve episódio de piora do SK em relação aos genótipos não $B(p=0,04)$. Os subgenótipos de HHV-8 presentes no grupo 1-SK e com registro sobre piora ou não de SK foram $A 1, A 2, A 4$, A5, B1, C3 e F (Tabela 12). Foi observado o predomínio significativo do intratipo B1 do que não B1 $(p=0,04)$ entre aqueles sem nenhum episódios de piora do SK (grupo 1-SK). A Tabela 12 apresenta a distribuição de casos entre os subgenótipos de HHV-8 que foram encontrados entre os indivíduos do grupo 1-SK em relação a ocorrência ou não de piora clínica do SK.

Tabela 12 - Distribuição do número de indivíduos de acordo com a presença de episódio de piora do SK e subgenótipos de HHV-8 presentes no grupo $1-\mathrm{SK}$.

\begin{tabular}{|c|c|c|c|c|}
\hline \multirow{3}{*}{$\frac{\text { K1 }}{\text { Subgenótipos }}$} & \multicolumn{4}{|c|}{ Grupo 1 -SK } \\
\hline & \multicolumn{3}{|c|}{ com episódio de piora do SK } & \multirow[t]{2}{*}{ total } \\
\hline & $\operatorname{sim}$ & não & NR & \\
\hline A1 & 2 & 0 & 0 & 2 \\
\hline A2 & 0 & 2 & 1 & 3 \\
\hline A4 & 1 & 1 & 0 & 2 \\
\hline A5 & 0 & 1 & 0 & 1 \\
\hline B1 & 1 & 8 & 3 & 12 \\
\hline C3 & 6 & 3 & 3 & 12 \\
\hline $\mathbf{F}$ & 0 & 0 & 1 & 1 \\
\hline NEG & 0 & 0 & 1 & 1 \\
\hline Total & 10 & 15 & 9 & 34 \\
\hline
\end{tabular}


Embora os dados sobre os níveis de CD4+ ao longo do tempo não tenham sido avaliados nesse estudo, o episódio de piora clínica de SK ocorreu mesmo diante de contagem de células T CD4+ maior ou igual a 300 células por $\mathrm{mm}^{3}$. Três casos apresentaram CD4 maior que 300 células $/ \mathrm{mm}^{3}$, com pelo menos um episódio de piora de SK registrado no momento da coleta de material biológico para admissão no estudo, sendo infectados com os subgenótipos de HHV-8 A1, C3 e B1 de HHV-8. Três casos tiveram nível CD4+ menor ou igual a 250 células por $\mathrm{mm}^{3}$ e, pelo menos um episódio de piora na mesma ocasião da contagem de CD4+, pertencendo aos subgenótipos C3 $(n=02)$ e A1 $(n=01)$ de HHV-8. Dos dez casos com episódio de piora de SK, 4 não tiveram registro de contagem de CD4+ na ocasião, sendo eles infectados com os subgenótipos C3 e A4 do HHV-8. Observamos dois registros de óbito entre aqueles com piora de SK, um subgenótipo A1 (nível de CD4+ igual a 6 células $/ \mathrm{mm}^{3}$ ) e um com subgenótipo C3 de HHV-8 (sem registro sobre contagem de CD4+).

Os valores de CD4+ no grupo 2 sem SK foram bem acima dos valores relacionados ao risco de doenças oportunistas, e vale lembrar que todos tinham DNA de HHV-8 circulantes na saliva. Outrossim, sete (7/40) indivíduos do grupo 2 nSK tinham níveis de CD4+ menores que 250 células $/ \mathrm{mm}^{3}$ no momento da coleta de material biológico (data da admissão no estudo) distribuídos entre os genótipos $A$ $(n=01), B(n=02)$ e C $(n=04)$. Foi observada a presença dos subgenótipos $A 1(n=1)$, B1 (n=02), C1 (n=01) e C3 (n=3) em indivíduos com CD4+ menor do que 250 células $/ \mathrm{mm}^{3}$ no grupo $2-\mathrm{nSK}$.

\subsubsection{Categorias de risco de transmissão de HIV}

Não houve presença preferencialmente significativa de um dado genótipo de HHV-8 em dada categoria de risco nos grupos estudados. No grupo 1 - SK, um total 
de 4/8 HSH (50,0\%) tiveram HHV-8 do genótipo A, e 5/12 (41,6\%) tiveram HHV-8 dos genótipos B ou C.

No grupo 2, um total de 4/14 HSH (28,6\%) foram do genótipo A, enquanto $7 / 14(50,0 \%)$ e 10/14 (71,4\%) foram dos genótipos B e C, respectivamente.

A Tabela 13 apresenta a distribuição dos genótipos de HHV-8 presentes em $\mathrm{HSH}$ comparativamente a outras categorias de risco de transmissão viral (em heterossexuais, em bissexuais, em profissionais do sexo, no risco transfusional, em indivíduo com parceiro HIV positivo e em usuário de drogas injetáveis).

Tabela 13 - Distribuição do número de indivíduos HSH ou não HSH e genótipos de HHV-8 entre os grupos de estudo.

\begin{tabular}{|c|c|c|c|c|c|c|c|}
\hline & \multirow[b]{2}{*}{ RISCO } & \multicolumn{6}{|c|}{ Genótipos de HHV-8 } \\
\hline & & A & B & C & $\mathbf{F}$ & NEG & Total \\
\hline \multirow[t]{4}{*}{ Grupo 1-SK } & $\mathrm{HSH}$ & 4 & 5 & 5 & 0 & 0 & 14 \\
\hline & Outros & 3 & 5 & 6 & 0 & 1 & 15 \\
\hline & NR & 1 & 2 & 1 & 1 & 0 & 5 \\
\hline & SK- total & 8 & 12 & 12 & 1 & 1 & 34 \\
\hline \multirow[t]{4}{*}{ Grupo 2-nSK } & $\mathrm{HSH}$ & 4 & 7 & 10 & 1 & 4 & 26 \\
\hline & Outros & 1 & 7 & 4 & 0 & 3 & 15 \\
\hline & NR & 0 & 0 & 0 & 0 & 0 & 0 \\
\hline & nSK- total & 5 & 14 & 14 & 1 & 7 & 41 \\
\hline Total & & 14 & 26 & 26 & 2 & 8 & 75 \\
\hline
\end{tabular}

NR= Não Registrado. HSH $=$ Homens que fazem sexo com homens, homossexuais exclusivamente masculinos, excetuando bissexuais. Outros $=$ heterossexuais, bissexuais, transfusão, UDI e outros. NEG = K1 Negativo e K12 positivo.

Entre os indivíduos com registro de pertencer a categorias de risco de adquirir HIV por transfusão de sangue $(n=01)$ e dois $(n=02)$ por uso de drogas injetáveis, houve a presença dos subgenótipos A5 e C7, B1 do HHV-8, respectivamente. Os Subgenótipos B2, C1, C2, C5 foram detectados exclusivamente em HSH do grupo 2- nSK e não nos outros indivíduos não HSH. Subgenótipo A4 foi detectado em 2 indivíduos HSH do grupo 1-SK. 


\subsubsection{Cor de pele autoreferida}

A relação dos genótipos de HHV-8 e a raça associada à cor da pele autoreferida foi investigada (Tabela 14). Houve maior predomínio dos genótipos B e C em indivíduos de cor branca em ambos os grupos 1- SK e grupo 2 - nSK, sem diferença estatisticamente significativa.

Tabela 14 - Distribuição dos genótipos (subtipos) de HHV-8 entre os indivíduos do grupo 1 - SK e grupo 2 - nSK, de acordo com a cor de pele.

\begin{tabular}{ccccccccc}
\hline Grupos de estudo & Cor de pele & \multicolumn{3}{c}{ Genótipos de HHV-8 } & (n) & \\
\cline { 3 - 6 } & & A & B & C & F & NEG & total \\
\hline Grupo 1-SK & Branco & 4 & 9 & 9 & 0 & 1 & 23 \\
& Outro & 3 & 2 & 1 & 1 & 0 & 7 \\
& NR & 1 & 1 & 2 & 0 & 0 & 4 \\
Grupo 2 -nSK & total & 8 & 12 & 12 & 1 & 1 & 34 \\
& Branco & 4 & 10 & 11 & 1 & 5 & 32 \\
& Outro & 1 & 4 & 2 & 0 & 1 & 8 \\
& NR & 0 & 0 & 1 & 0 & 1 & 1 \\
& total & 5 & 14 & 14 & 1 & 7 & 41 \\
& Total & 14 & 26 & 26 & 2 & 8 & 75 \\
\hline
\end{tabular}

Outro = registro como mulato, amarelo, negro ou pardo;NR = dado Não Registrado; NEG = K1 Negativo e K12 positivo; $n$ = número de casos.

Os subgenótipos de HHV-8 A2 (n=04), C2 ( $n=01)$, C7 ( $n=01)$ e A5 ( $n=01)$ foram exclusivos dos indivíduos brancos, e os subgenótipos A4 ( $n=01)$ e C5 ( $n=01)$ foram exclusivos dos indivíduos não brancos, independente do grupo de estudo ao qual pertenceram (grupo 1 ou 2), embora a diferença não foi significativa estatisticamente devido ao número restrito de casos. 


\subsubsection{Quadro clínico de adoecimento com aids}

Todos indivíduos do grupo 1 - SK apresentaram quadro clínico de aids. No entanto, nove $(n=09)$ indivíduos do grupo 2 - nSK não apresentaram adoecimento com aids, dentre esses foram encontrados os genótipos ou subtipos $A(n=01), B$ $(n=05)$ e C $(n=03)$ de HHV-8.

Os indivíduos que não tiveram adoecimento com aids apresentaram os subgenótipos A2, B1, C3 e C7 de HHV-8, nas sequintes proporções: 1 caso (11\%) de intratipo A2 (nFOX286), 5 casos (56\%) de intratipo B1 (nFOX230, nFOX295, nFOX311, nFOX377, nFOX385), 2 casos (22\%) de intratipo C3 (FOX238, FOX292) e um $(n=01)$ caso $(11 \%)$ de intratipo C7 $(n F O X 18)$. Em três casos $(n=03)$ do grupo 1-SK e oito (n=08) do grupo 2-nSK, não foi possível obter informação sobre registro de aids.

\subsubsection{Infecção por HHV-8 e carga viral de HHV-8 em indivíduos sem SK}

Não houve diferença significativa entre a média dos valores da carga viral de HHV-8 entre os genótipos A, B e C do HHV-8 no grupo 2-nSK $(p=0,77)$.

Sete $(n=07)$ indivíduos foram positivos exclusivamente para o locus K12 (NEG), tendo a média do log da carga viral de 3,14 cópias por $\mu$ g de DNA, variando o log da carga viral de 0,55 a 4,94 cópias por $\mu \mathrm{g}$ de DNA. Não houve diferença $(p=0,10)$ entre a carga viral das amotras genotipadas (K1 A, B C) e K1 NEG (K1 negativas K12 positivas).

As amostras com sequências de HHV-8 negativas para ambos os loci $\mathrm{K} 1 \mathrm{e}$ K12 ( $n=65)$ não fizeram parte do critério de inclusão para a composição do grupos 2 , no entanto ressaltamos que apresentaram o log da média da carga viral de 3,06 cópias por $\mu \mathrm{g}$ de DNA, variando o log da carga viral de 0,55 a 5,66 cópias por $\mu \mathrm{g}$ 
de DNA. Houve diferença significativa entre o log da carga viral de HHV-8 entre as amostras genotipadas e não genotipadas $(p=0,004)$.

A média geral do log do número de cópias de HHV-8 detectada na saliva do grupo 2 ( $n=41)$ foi de 3,96 cópias por $\mu$ g de DNA, variando o log da carga viral de 0,55 a 6,82 cópias por $\mu \mathrm{g}$ de DNA. A maior quantidade de cópias na saliva foi representada pelo subgenótipo B1 (6.605.179 cópias por $\mu \mathrm{g}$ de DNA) e a menor representada pelo subgenótipo A1 (4 cópias por $\mu \mathrm{g}$ de DNA).

A Figura 18 apresenta a comparação da carga viral de HHV-8 na saliva entre os genótipos $\mathrm{A}$, B e $\mathrm{C}$ do vírus.

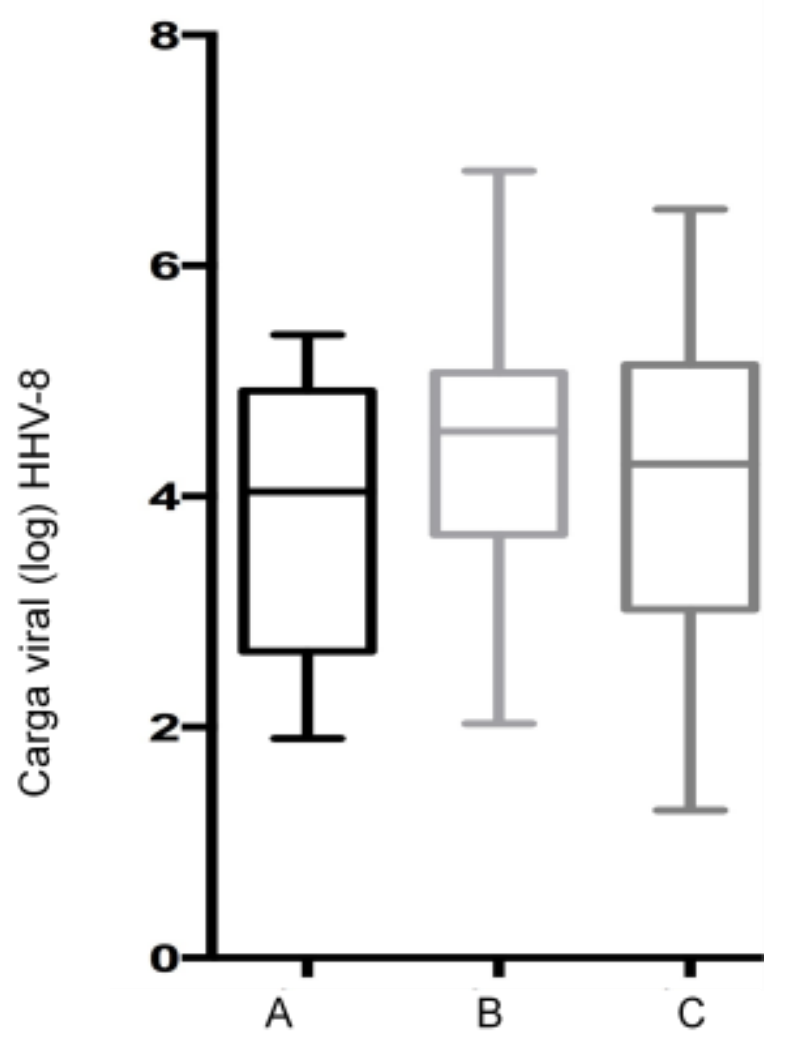

Figura 18 - Comparação da carga viral (log) de HHV-8 dos 41 indivíduos do grupo 2-nSK, em relação aos genótipos $A, B$ e C. $p=0,77$. 
O genótipo $\mathrm{F}$ foi detectado na saliva de um ( $\mathrm{n}=01)$ indivíduo (log da carga viral foi 2,08 cópias por $\mu$ g de DNA) sem SK. A Tabela 15 apresenta a distribuição dos valores de log da quantidade de cópias de $\mathrm{HHV}=8$ na saliva (média, mediana, mínimo, máximo e desvio padrão) entre os subgenótipos de HHV-8. Os subgenótipos C1, C2 e C5 foram detectados em uma amostra cada um, apresentaram o log da carga viral de HHV-8 de 4,28; 4,45 e 5,45 $\mu \mathrm{g}$ de DNA, repectivamente. Por serem exemplares únicos, esses não fizeram parte da Tabela 15.

Tabela 15 - Comparação do log da carga viral de HHV-8 (cópias por $\mu$ g de DNA) de acordo com os subgenótipos de HHV-8 detectados na saliva de indivíduos HIV sem SK, grupo 2 - nSK.

\begin{tabular}{ccccccc}
\hline K1 Subgenótipos & Média & D.P & Mediana & Min. & Max. & total \\
\hline A1 & 2,29 & 1,61 & 4,43 & 0,55 & 4,43 & 3 \\
\hline A2 & 4,72 & 0,68 & 4,57 & 4,04 & 5,40 & 2 \\
\hline B1 & 4,16 & 1,24 & 4,21 & 2,03 & 6,82 & 12 \\
\hline B2 & 5,01 & 0,81 & 5,01 & 4,2 & 5,82 & 2 \\
C3 & 3,85 & 1,55 & 3,90 & 1,28 & 6,49 & 9 \\
\hline C7 & 3,90 & 0,49 & 4,57 & 3,41 & 4,39 & 2 \\
\hline K1 NEG & 3,42 & 1,46 & 3,65 & 0,55 & 4,94 & 7 \\
\hline
\end{tabular}

$\mathrm{K} 1 \mathrm{NEG}=\mathrm{K} 1$ negativo e K12 positivo. Min. = Mínimo; Max. = máximo.

D.P = Desvio Padrão.

\subsubsection{Diagnóstico de HIV}

De acordo com a Tabela 16 a maioria dos casos de diagnóstico da infecção por HIV no grupo 1 - SK foi entre 1997 a 1999. Houve maior número de casos de indivíduos infectados por HIV após 1996 (Tabela 16) ( $n=25)$, por isso houve possibiidade de observar entre esses indivíduos a ampla variação de subgenótipos A de HHV-8, como os intratipos A1 ( $n=01), A 2(n=02), A 4(n=02), A 5(n=01)$. Não foi observada variação dentro dos genótipos B e C, isto é, houve um total de $100 \%$ de 
subgenótipos $B 1$ e C3. O genótipo ou subtipo $F(n=01)$ foi encontrado em indivíduo com SK e com infecção por HIV diagnosticada em 1998.

Tabela 16 - Distribuição do número de indivíduos do grupo 1 -SK conforme subgenótipos de HHV-8 e ano do diagnóstico do HIV entre o ano de 1987 a 2000.

\begin{tabular}{|c|c|c|c|c|c|c|c|c|c|}
\hline \multirow{3}{*}{$\begin{array}{c}\text { Grupo } 1 \\
\text { Diag. HIV }\end{array}$} & \multicolumn{7}{|c|}{ Subgenótipos de HHV-8 } & \multirow{3}{*}{$\begin{array}{l}\text { K1 } \\
\text { NEG }\end{array}$} & \multirow[b]{3}{*}{ total } \\
\hline & \multicolumn{7}{|c|}{$1998-1999$} & & \\
\hline & A1 & A2 & A4 & A5 & B1 & C3 & $\mathbf{F}$ & & \\
\hline 1987 & & & & & 1 & & & & 1 \\
\hline 1990 & 1 & & & & & & & & 1 \\
\hline 1993 & & & & & & 1 & & & 1 \\
\hline 1994 & & 1 & & & & 1 & & & 2 \\
\hline 1995 & & & & & 1 & 1 & & & 2 \\
\hline 1996 & & & 1 & 1 & & & & & 2 \\
\hline 1997 & & 1 & & & 2 & 3 & & 1 & 7 \\
\hline 1998 & & 1 & & & 4 & 2 & 1 & & 8 \\
\hline 1999 & 1 & & & & 3 & 3 & & & 7 \\
\hline 2000 & & & & & 1 & 1 & & & 2 \\
\hline NR & & & 1 & & & & & & 1 \\
\hline Total & 2 & 3 & 2 & 1 & 12 & 12 & 1 & 1 & 34 \\
\hline
\end{tabular}

$\mathrm{NR}=$ dado Não registrado.

Ano de 1996 = marco da era HAART no mundo.

No grupo 2 - nSK foram detectadas sequências de HHV-8 nas amostras de salivas coletadas na ocasião da admissão no protocolo do estudo em 2007 em indivíduos que foram infectados por HIV entre 1987 a 2007, sendo a maioria dos diagnósticos de HIV a partir do ano de 1997 a 2003, de acordo com a Tabela 17.

No grupo 2-nSK, igualmente foi observado um maior número de registros de infecção por HIV após 1996. Todavia, diferente do grupo 1-SK, foi possível encontrar maior variabilidade de subgenótipos B e C de HHV-8: B2 ( $n=02)$, C2 ( $n=01)$, C5 ( $n=01$ ). Os subgenótipos ou intratipos de HHV-8 A1, A2, B1, C3 e o genótipo $F$ foram detectados em ambos os grupos. 
Tabela 17 - Distribuição do número de indivíduos do grupo 2 - nSK conforme subgenótipos de HHV-8 detectados na ocasião desse estudo e a data do diagnóstico do HIV (entre o ano de 1987 a 2007).

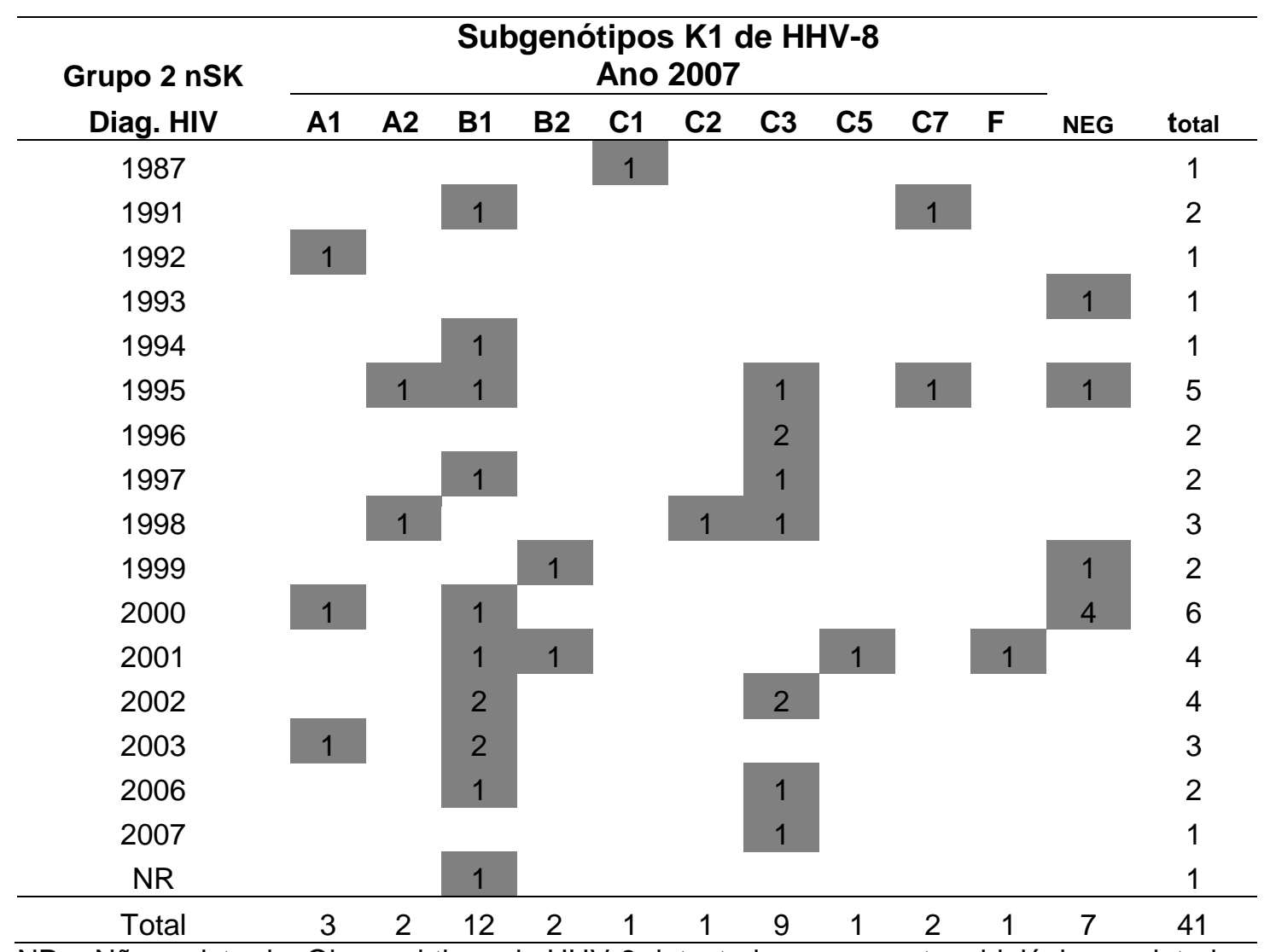

$\overline{N R}$ = Não registrado; Obs.: subtipos de HHV-8 detectados em amostras biológicas coletadas em 2007 de indivíduos do grupo 2 -nSK e infectados por HIV na era pré e pós HAART (antes e após 1996).

\subsubsection{Tempo de uso de ART}

Dos 75 indivíduos pertencentes aos grupos de estudo, 52 tiveram informação sob a data de início do uso de ART, numa margem de 0 a 14 anos de uso de ART. Nos grupos 1 e 2 , todos estavam sob o uso de ART, mas não houve registro sobre a data de início do uso de ART em 1 caso do grupo 1 -SK e em 11 casos do grupo 2-nSK. O tempo de uso de ART foi medido desde o ano da introdução da ART até o ano de admissão no estudo (data da coleta do material biológico, anos 1998 ou 1999 ou 2007). A detecção dos genótipos de HHV-8 em indivíduos sob uso de ART foi apresentada na Tabela 18. Independente do tempo 
de início de exposição ao ART, o subgenótipo B1 esteve presente entre os indivíduos tanto do grupo 1 quanto do grupo 2. Visto que o tempo de ART e o tempo de diagnóstico de HIV foram proporcionais, as mesmas observações foram tomadas para ambo os parâmetros, isto é, houve variabilidade particularmente de subgenótipos de C de HHV-8 no grupo 2-nSK, sendo presentes C2, C3 e C5 e C7 de HHV-8 em indivíduos com mais de 4 anos de exposição ao ART. Da mesma forma, no grupo 1-SK não houve variabilidade do subgenótipo $\mathrm{C}$ de HHV-8, isto é, 100\% foram do subgenótipo C3 do HHV-8, detectados em 1998 ou 1999.

Tabela 18 - Distribuição dos genótipos/subgenótipos de HHV-8 segundo o tempo de uso de ART até a ocasião da admissão do estudo.

\begin{tabular}{|c|c|c|c|c|c|c|c|c|c|}
\hline \multicolumn{10}{|c|}{$\begin{array}{c}\text { Genótipos/subgenótipos K1 - HHV-8 } \\
\text { n' }\end{array}$} \\
\hline $\begin{array}{l}\text { Tempo } \\
\text { uso }\end{array}$ & \multicolumn{3}{|c|}{ Grupo 1 - SK } & \multicolumn{3}{|c|}{ Grupo 2 - nSK } & \multicolumn{2}{|c|}{$\begin{array}{l}\text { Grupo } \\
1 \text { e } 2\end{array}$} & \\
\hline ART & \multicolumn{3}{|c|}{ 1998-1999* } & \multicolumn{3}{|c|}{$2007^{*}$} & & & \\
\hline (anos) & $A$ & $B$ & $\mathrm{C}$ & $A$ & $B$ & $\mathrm{C}$ & $F$ & NEG & total \\
\hline 0 & $3^{A 2}$ & $7^{\mathrm{B} 1}$ & $4^{\mathrm{C} 3}$ & & $1^{\mathrm{B} 1}$ & $1^{\mathrm{C} 3}$ & & & 16 \\
\hline 1 & & $2^{B 1}$ & $1^{\mathrm{C} 3}$ & & & $2^{\mathrm{C} 3}$ & & & 5 \\
\hline 2 & & & $1^{\mathrm{C} 3}$ & & & & & & 1 \\
\hline 3 & $2^{\mathrm{A} 1, \mathrm{~A} 5}$ & & $1^{\mathrm{C} 3}$ & $1^{\mathrm{A} 1}$ & $2^{B 1}$ & & & & 6 \\
\hline 4 & & & & & & $1^{\mathrm{C} 3}$ & & & 1 \\
\hline 5 & & & & & $1^{\mathrm{B} 2}$ & & & & 1 \\
\hline 6 & & & & & & $2^{\mathrm{C} 3, \mathrm{C} 5}$ & & & 2 \\
\hline 7 & & & & & $1^{\mathrm{B} 1}$ & & & 1 & 2 \\
\hline 8 & & & & & $1^{\mathrm{B} 2}$ & & & & 1 \\
\hline 10 & & & & $1^{\mathrm{A} 2}$ & & $4^{\mathrm{C2}, 2 \mathrm{C} 3, \mathrm{C7}}$ & & 1 & 6 \\
\hline 11 & & & & & $1^{\mathrm{B} 1}$ & $2^{\mathrm{C} 1, \mathrm{C} 3}$ & & & 3 \\
\hline 12 & & & & & $1^{\mathrm{B1}}$ & $2^{\mathrm{C3,C7}}$ & & & 3 \\
\hline 13 & & & & $2^{\mathrm{A} 1, \mathrm{~A} 2}$ & & & & 1 & 3 \\
\hline 14 & & & & & $1^{\mathrm{B} 1}$ & & & & 1 \\
\hline Sim & $3^{2 \mathrm{~A} 4, \mathrm{~A} 1}$ & $3^{B 1}$ & $4^{\mathrm{C} 3}$ & & & & 1 & & 11 \\
\hline não & & & & & $1^{\mathrm{B} 1}$ & & & & 1 \\
\hline NR & & & $1^{\mathrm{C} 3}$ & $1^{\mathrm{A1}}$ & $4^{B 1}$ & & 1 & 5 & 12 \\
\hline Total & 8 & 12 & 12 & 5 & 14 & 14 & 2 & 8 & 75 \\
\hline
\end{tabular}

*Ano de admissão no estudo, ou da ocasião da coleta do material biológico;

$n^{\prime}=$ número de casos com dado genótipo (subtipo) e sobrescrito ao número, os subgenótipos de HHV-8 encontrados. Sim = sob uso de ART mas sem registro da data de início do uso de ART; não = não uso de ART. 


\subsubsection{Carga viral do HIV}

Não foi observada a presença do genótipo A do HHV-8 em indivíduos na condição de carga viral de HIV baixa (log da carga viral de HIV menor do que 3,0 cópias ou 1.208 cópias $/ \mathrm{mL}$ ); em contrapatida observou-se maior proporção de subgenótipo A2 (6/8) de HHV-8 na condição de log da carga viral de HIV maior que 3,0 cópias por $\mathrm{mL}$, tanto no grupo 1-SK quanto no grupo 2 -nSK, porém sem significado estatístico devido ao limitado número de casos. Os subgenótipos A1, A5, B1, C2, C3, C5 e C7 de HHV-8 foram detectados em indivíduos com carga viral de HIV indetectável e houve presença exclusiva dos intratipos C2 e C7 e intertipo C5 de HHV-8 no grupo 2 -nSK diante com carga viral de HIV indetectável (Tabela 19).

Tabela 19 - Distribuição do número de genótipos de HHV-8 em relação a carga viral de HIV avaliado no grupo 1 com SK e grupo 2 sem SK. Subrescrito ao número estão identificados os subgenótipos.

\begin{tabular}{|c|c|c|c|c|c|c|}
\hline \multicolumn{7}{|c|}{$\begin{array}{l}\text { Grupo 1-SK - Genótipos e } \\
\text { subgenótipos K1 de HHV-8 }\end{array}$} \\
\hline C.V - HIV (log) & A & B & C & $\mathbf{F}$ & NEG & total \\
\hline$<3,0$ & & $4^{\mathrm{B} 1}$ & $3^{\mathrm{C} 3}$ & & & 7 \\
\hline$>$ ou $=3,0$ & $5^{\mathrm{A} 1,3 \mathrm{~A} 2, \mathrm{~A} 4}$ & $5^{\mathrm{B} 1}$ & $3^{\mathrm{C} 3}$ & & & 13 \\
\hline Indetect. & $1^{\mathrm{A} 5}$ & & & & 1 & 2 \\
\hline NR & $2^{\mathrm{A} 1, \mathrm{~A} 4}$ & $3^{B 1}$ & $6^{\mathrm{C} 3}$ & 1 & & 12 \\
\hline Total & 8 & 12 & 12 & 1 & 1 & 34 \\
\hline \multicolumn{7}{|c|}{$\begin{array}{r}\text { Grupo -nSK } \\
\text { Genótipos e subgenótipos }\end{array}$} \\
\hline$<3,0$ & & $1^{B 1}$ & $3^{\mathrm{C3}}$ & & & 4 \\
\hline$>$ ou $=3,0$ & $3^{\mathrm{A} 1,2 \mathrm{~A} 2}$ & $7^{6 \mathrm{~B} 1, \mathrm{~B} 2}$ & $4^{\mathrm{C} 1,2 \mathrm{C} 3, \mathrm{C} 7}$ & 1 & 1 & 16 \\
\hline Indet. & $1^{\mathrm{A} 1}$ & $5^{4 \mathrm{~B} 1, \mathrm{~B} 2}$ & $7^{\mathrm{C} 2,4 \mathrm{C} 3, \mathrm{C} 5, \mathrm{C} 7}$ & & 3 & 16 \\
\hline NR & $1^{\mathrm{A} 1}$ & $1^{\mathrm{B} 2}$ & & & 3 & 5 \\
\hline Total & 5 & 14 & 14 & 1 & 7 & 41 \\
\hline
\end{tabular}

NR = Não Registrado; Indetect. = indetectável; C.V = carga viral.

\subsubsection{Faixa etária e gênero}


Não foi observada diferença entre genótipos de HHV-8 e a faixa etária em ambos os grupos devido ao número limitado entre as categorias. No entanto, foi possível observar que um total de 6/8 (75\%) sequências de HHV-8 do genótipo A foi detectado em indivíduos com idade inferior a 40 anos de idade do grupo 1 - SK. Observou-se uma particular diversidade de subgenótipos A no grupo 1-SK com idade inferior a 40 anos (A1, A2, A4), enquanto os subgenótipos B1 e C3 de HHV-8 predominaram independente da faixa etária inferior ou superior a 40 anos, no grupo 1 -SK. Em contrapartida, foi observada diversidade de subgenótipos $\mathrm{C}(\mathrm{C} 1, \mathrm{C} 2$, C3 C5 e C7) de HHV-8 em saliva dos indivíduos do grupo 2-nSK, que apresentaram, a maioria, idade superior a 40 anos na ocasião do estudo. Os dois casos de genótipo F de HHV-8 ocorreram em indivíduos de 28 e 35 anos.

Um total de $8 \%(6 / 75)$ dos indivíduos do estudo foi do sexo feminino, pertencentes aos subgenótipos de HHV-8 B1 $(n=02)$ e A5 ( $n=01)$ com idades de 36, 39 e 65 anos no grupo 1- SK, enquanto no grupo 2 - nSK, pertencentes aos subgenótipos B1 ( $n=02)$ e A1 ( $n=01)$ com idades de 32, 35 e 52 anos (Tabela 20).

Tabela 20 - Distribuição do número de indivíduos de acordo com a faixa etária e genótipos e subgenótipos de HHV-8.

\begin{tabular}{|c|c|c|c|c|c|c|}
\hline \multicolumn{7}{|c|}{ Genótipos e subgenótipos de K1 } \\
\hline $\begin{array}{c}\text { Faixa etária } \\
\text { (anos) }\end{array}$ & A & B & C & $\mathrm{F}$ & NEG & total \\
\hline \multicolumn{7}{|c|}{ Grupo 1-SK } \\
\hline$<40$ & $6^{2 \mathrm{~A} 1,2 \mathrm{~A} 2,2 \mathrm{~A} 4}$ & $8^{\mathrm{B} 1}$ & $5^{\mathrm{C3}}$ & 1 & 0 & 18 \\
\hline$>0 u=40$ & $2^{\mathrm{A2}, \mathrm{A5}}$ & $4^{\mathrm{B} 1}$ & $7^{\mathrm{C} 3}$ & 0 & 1 & 16 \\
\hline Total & 8 & 12 & 12 & 1 & 1 & 34 \\
\hline \multicolumn{7}{|c|}{ Grupo 2 -nSK } \\
\hline$<40$ & $2^{\mathrm{A} 1}$ & $7^{6 \mathrm{~B} 1, \mathrm{~B} 2}$ & $5^{4 \mathrm{C} 3, \mathrm{C} 5}$ & 1 & 0 & 15 \\
\hline$>\mathrm{Ou}=40$ & $3^{\mathrm{A} 1,2 \mathrm{~A} 2}$ & $7^{6 \mathrm{~B} 1, \mathrm{~B} 2}$ & $9^{\mathrm{C} 1, \mathrm{C} 2,5 \mathrm{C} 3,2 \mathrm{C} 7}$ & 0 & 7 & 26 \\
\hline Total & 5 & 14 & 14 & 1 & 7 & 41 \\
\hline
\end{tabular}

4.7 Característica de variabilidade das sequências de DNA de HHV-8 


\subsubsection{Características sugestivas de recombinação}

As análises de recombinação foram feitas através de dois programas distintos. O primeiro, o SimPlot detectou claramente três eventos de recombinação, já descritos anteriormente na literatura. Entre as três sequências recombinantes de HHV-8, uma foi do subgenótipo/intertipo C5 (exemplo nFOX129) e as outras duas do subgenótipo/intratipo C7 (exemplos nFOX 18, nFOX 678), todas isoladas de saliva de indivíduos infectados por HIV sem manifestação de SK (grupo 2 - nSK) na análise do locus K1.

A Figura 19 apresenta um exemplo desse estudo da predição de um evento de recombinação detectado na sequência de DNA de HHV-8 locus K1 da amostra nFOX18 em que foi possível determinar o ponto de recombinação entre o subtipo $A$ e C na posição do nucleotídeo 577 pelo programa SIMPLOT.



Figura 19 - Evento de recombinação detectado pelo programa SIMPLOT na posição do nucleotídeo 577 da sequência de DNA de HHV-8 (nFOX18) locus K1. Recombinação entre os parentais do genótipo A (linha em vermelho) e C (linha em amarelo). 
Além do SimPLot para detecção de recombinação, as análises foram feitas também utilizando o programa RDP. Entretanto, utilizando esse programa diversos eventos sugestivos de recombinação foram identificados, com alto valor de probabilidade, mas sem que as sequências parentais pudessem ser determinadas. Além disso, o pacote RDP utiliza diversas ferramentas de predição de recombinantes. Assim, resolvemos somente considerar eventos reais de recombinação sequências que fossem indicadas por, pelo menos, três indicações distintas do pacote RDP. A Figura 20 apresenta em barras descontínuas a representação da predição de recombinantes a partir das amostras desse estudo por meio do método SISCAN (Sister-scanning) do pacote RDP (Recombination Detection Program).
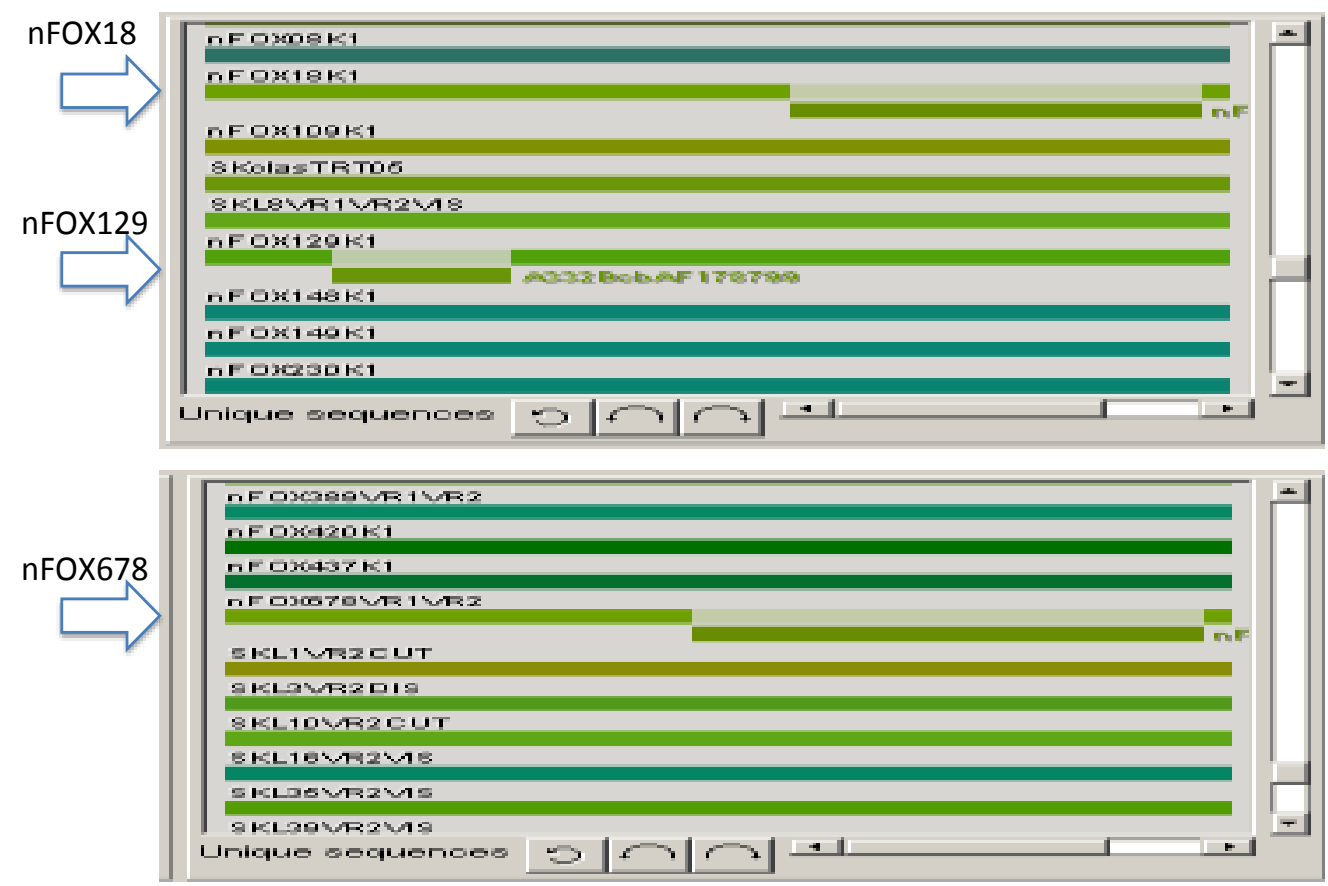

Figura 20 - Método SISCAN do pacote RDP. Note a detecção dos possíveis eventos de recombinação observados nas três sequências de DNA de HHV-8 desse estudo, indicadas pelas setas azuis. $p<0,01$. 


\subsubsection{Deleções}

Observamos deleções em torno de 12, 15 e 39 nucleotídeos em sequências de DNA do HHV-8 entre a posição dos nucleotídeos 588 a 633 da região hipervariável VR2 do gene K1 (Figura 21), identificadas nos genótipos $A, B$ e $C$ do HHV-8 em indivíduos do grupo 1-SK e 2 - nSK. Referências obtidas do GenBank mostraram que essas deleções foram descritas em sequências de HHV-8 de regiões da África, Estados Unidos, Guiana Francesa, Itália, Grécia, Israel e Rússia.

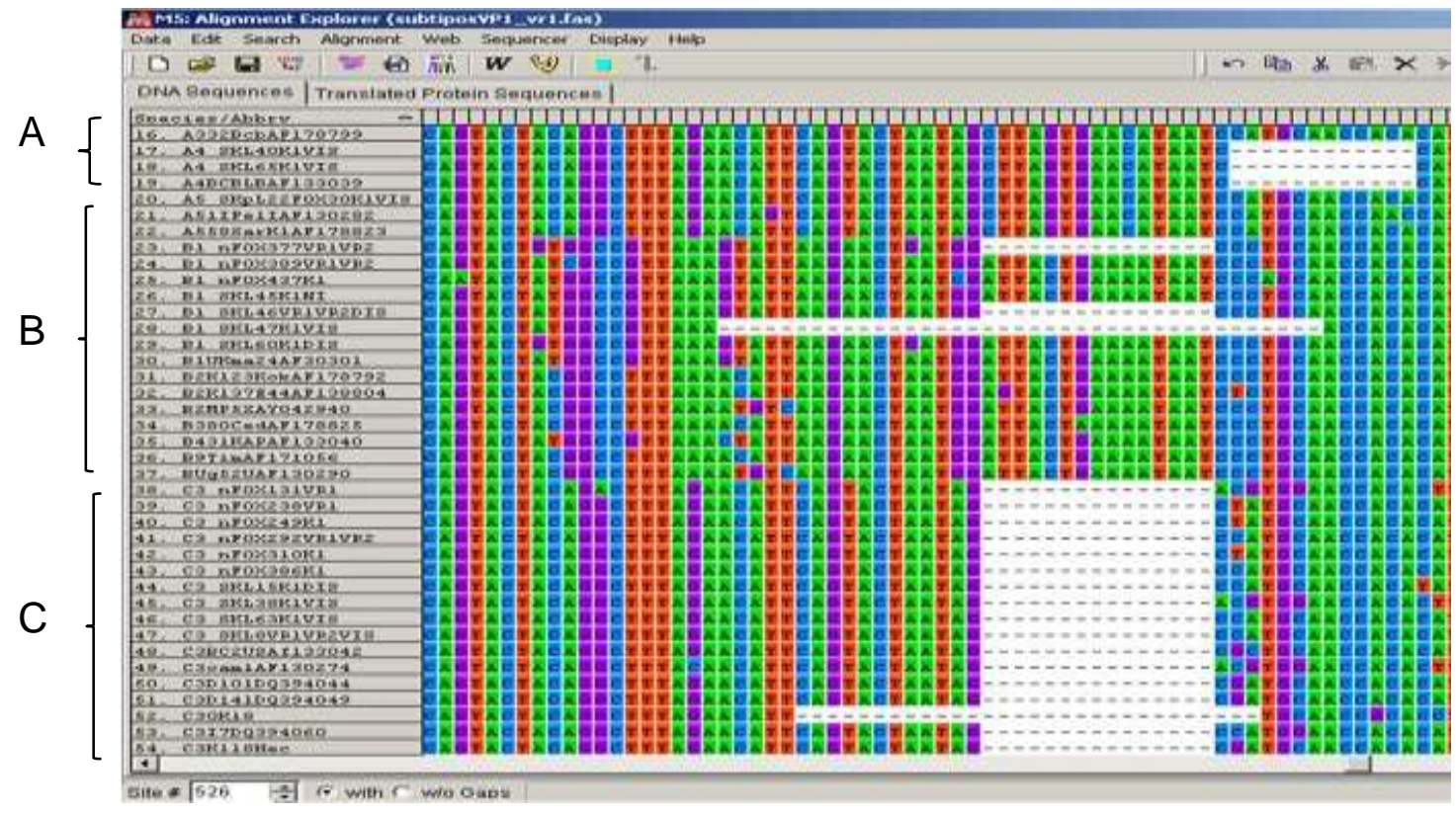

Figura 21 - Regiões de deleção variando de 12, 15 e 39 nucleotídeos na região K1/VR2 do HHV-8 presentes em sequências de DNA/ HHV-8 descritas nesse estudo, visualizadas no programa Mega 5.

Três regiões do locus K12 envolveram a deleção de 4 nucleotídeos, foram eles AAAT, AGTC, TGTT considerando a posição do primeiro nucleotídeo sendo 117622, 117721, 117955, respectivamente; condição característica em um único paciente com SK do genótipo F desse estudo (SKL50) e em um protótipo denominado SAN 1 de origem africana. As deleções não fazem parte da região codificadora da ORF K12. 


\subsubsection{Perfil de Mutações. Substituição sinônima e não sinônima}

A variabilidade genética do HHV-8 também foi avaliada conforme a presença de substituição sinônima e não sinônima nas sequências de HHV-8 obtidas no atual estudo e nos protótipos de K1 obtidos no GenBank. A Figura 22 apresenta o valor dN-dS estimado codon por codon nas sequências de HHV-8 do locus K1.

Os sítios positivamente e negativamente selecionados foram marcados ao longo do gene K1 (289 aminoácidos), de acordo com os valores dN-dS. O predomíno de sítios positivamente selecionados foram apontados na Figura 22. Foram 28 sítios selecionados positivamente, sendo seis sítios com poder estatístico altamente significativo $(p<0,005)$, e oito negativamente selecionados. A média da estimativa $d N / d S$ foi 2,59 . Seleção positiva altamente significativa foi presente nas sequências aqui estudadas e igualmente nas sequências protótipos para os seguintes códons e os seus respectivos aminoácidos: códon 63 (D, E, R, K, N, M, T, A, Q, R), códon 197 (T, E, V, L, M), códon 158 (A, T, S, L, V), códon 225 (L, P, T, R); e seleção negativa nos códons 104 ( Q) e 155 (G). 


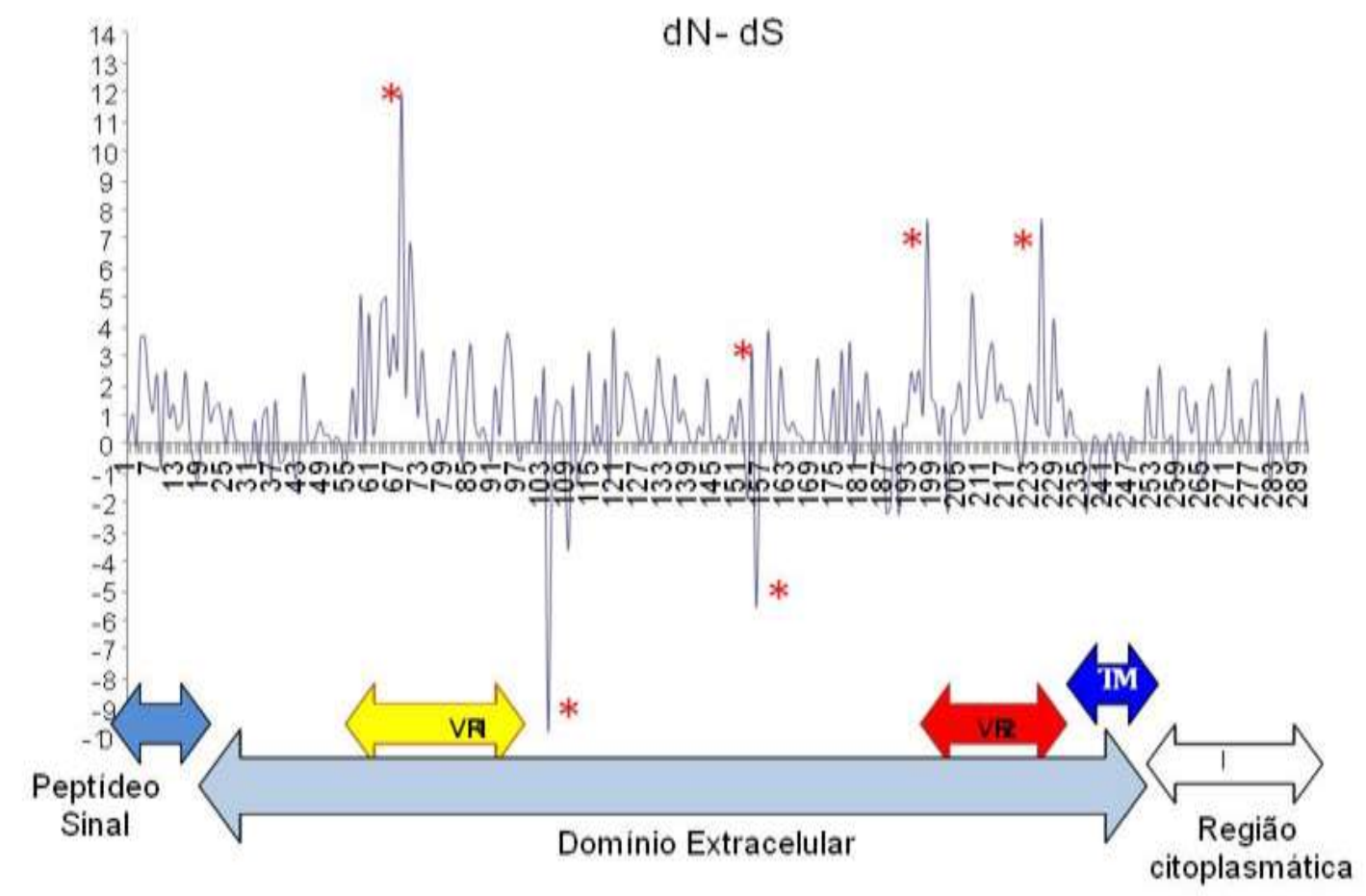

Figura 22 - Avaliação da estimativa dN-dS nas sequências com extensão de 289 aminoácidos (gene K1) de sequências de HHV-8. O valor dN-dS codon por codon foi estimado por meio do Datamonkey. As setas coloridas representam sítios de predição de domínio do peptídeo sinal (em azul), as regiões de hipervariabilidade VR1 (em amarelo) e VR2 (em vermelho), a predição de TM ou domínio transmembrana (em azul escuro) e o domínio citoplasmático (em branco). Note ao longo domínio extracelular (seta azul clara). O asterisco acima dos picos que indicam selecão positiva $(p<0,005)$ nos códons 63, 197, 158, 225 e seleção negativa nos códons 104 e 155 ( $\mathrm{p}<0,05)$. Códon 63 ( $\mathrm{D}, \mathrm{E}, \mathrm{R}, \mathrm{K}, \mathrm{N}, \mathrm{M}, \mathrm{T}, \mathrm{A}, \mathrm{Q})$, códon 197 ( $\mathrm{T}$, $E, V, L, M)$, códon $158(A, T, S, L, V)$, códon $225(L, P, T, R)$; e seleção negativa nos códons 104 (Q) e 155 (G). $D=$ =Aspartato; Ácido glutâmico; $R=$ Arginina; $\mathrm{K}=$ Lisina; $\mathrm{N}=$ Asparagina; $\mathrm{M}=$ Metionina; $\mathrm{T}=$ Treonina; $\mathrm{A}=$ Alanina; $\mathrm{Q}=$ Glutamina; $\mathrm{R}=$ Arginina; $\mathrm{V}=$ Valina; $\mathrm{L}=$ Leucina; $\mathrm{S}=$ Serina; $\mathrm{P}=$ Prolina; $\mathrm{G}=\mathrm{Glicina}$.

A peculiaridade de encontrarmos o predomínio de mutações não silenciosas foi exclusiva do gene $K 1$, visto que na análise das sequências do gene $K 12$ (sequência de 60 aminoácidos) nenhum sítio foi positivamente selecionado e apenas dois sítios foram selecionados negativamente nos grupos estudados aqui. 
Os códons 7 (Valina) e 42 (Prolina) representam sítios negativamente selecionados, com $p=0,001$ e $p=0,037$, respectivamente. A média da estimativa $d N / d S$ no locus K12 foi de 0,97 .

\subsubsection{Variabilidade da ORF K1 de HHV-8 quando houve sequências de DNA/HHV-8 obtidas em mais de uma amostra biológica em ocasiões diferentes do mesmo indivíduo (variabilidade intra- hospedeiro).}

A variabilidade de HHV-8 entre amostras biológicas do mesmo hospedeiro foi estudada em sequências de DNA de HHV-8 isoladas em diferentes períodos de coleta de sangue (entre 1998 a 1999) em cinco $(n=5)$ indivíduos do grupo 1 com SK (SKL-9-1 e SKL9-3; SKL63-1, SKL63-3; SKL69-1, SKL-69-2, SKL-69; SKL-31-1, SKL-31-3, SKL-31-10, SKL31; L47-1 e L47-4) e apresentaram pouca ou nenhuma variabilidade, avaliada pela alta identidade de nucleotídeos, conforme a reconstrução filogenética dos isolados obtidos das regiões K1/VR1 e K1/VR2 do HHV-8 (elementos sublinhados, Figura 16 A, 16B).

Dois indivíduos com SK tiveram coleta de sangue obtida em 1999 e de saliva em 2007 e o genótipo de HHV-8 identificado nos diferentes materiais biológicos do mesmo individuo num intervalo de 8 anos entre as coletas foi o mesmo, ambas as amostras pareadas de SKL5FOX25 foram pertencentes ao subgenótipo A2 e as amostras paredas de SKFOX30 foram do subgenótipo A5.

Um (n=01) indivíduo do grupo 2 nSK (FOX109) teve isolado de HHV-8 obtido de sangue e saliva pareados na mesma ocasião, e foi observada total identidade entre as sequência de nucleotídeos do locus $\mathrm{K} 1$ no sangue e na saliva, ambas as sequências de DNA de HHV-8 obtidas foram do subgenótipo A2. 


\subsubsection{Polimorfismos de um único nucleotídeo (SNPs) no locus K12}

No trecho entre os nucleotídeos 117417 e 118055 do genoma de referência U75698 (locus K12) foram detectadas 59 posições polimórficas. Não houve diferença estatística que distinguisse os grupos 1-SK e grupo 2-nSK de acordo com a presença ou ausência de cada um dos SNPs avaliados. Excluímos da análise estatística os SNPs presentes em apenas uma amostra, resultando 26/59 sítios polimórficos nas sequências de HHV-8 dos grupos de estudo apresentados na Figura 23.

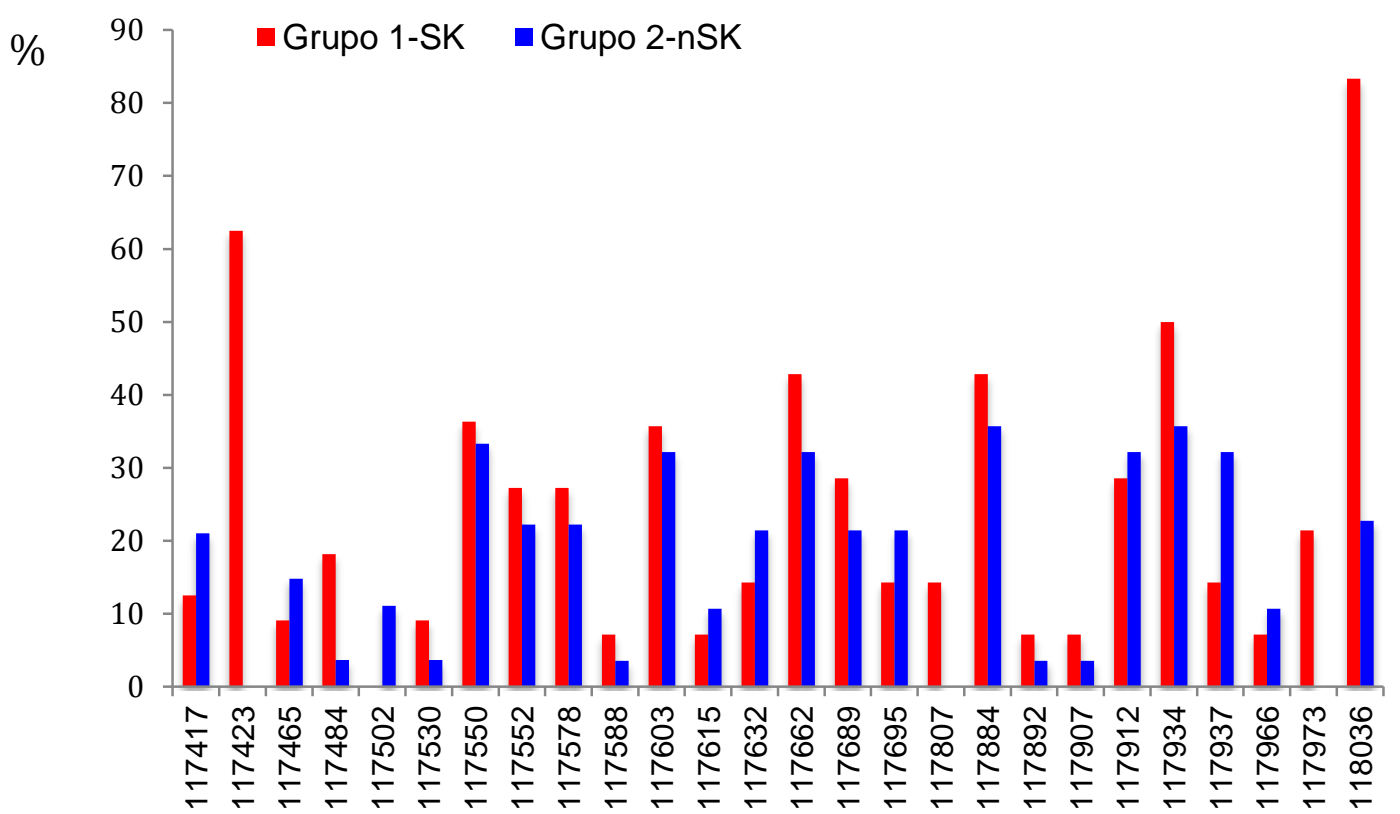

Figura 23 - Distribuição da frequência de amostras positivas para cada um dos 26 sítios polimórficos, de acordo com sua posição nucleotídica (117417 a 118055) ao longo do locus K12. As amostras representam sequências de HHV-8 do grupo 1-SK e grupo 2-nSK. Não houve diferença estatisticamente significativa entre grupo 1 (barra vermelha) e 2 (barra azul) em relação a cada um dos 26 sítios polimórficos $(p>0,05)$.

Conforme apresentado na Tabela 21, noventa e um $(n=91)$ SNPs foram detectados entre as sequências de HHV-8/K12 no grupo 1 -SK e cento e trinta sete ( $n=137)$ SNPs, no grupo 2 -nSK. Foram detectados 157 SNPs entre os 20 exemplares de HHV-8/K12 obtidos de lesões de SK epidêmico, endêmico, clássico, 
incuindo um protótipo de infeção por HHV-8 assintomática de área endêmica do Equador (GenBank, Tabela 5).

A Tabela 21 apresenta a distribuição do número de SNPs positivos em relação à determinada coordenada (posição nucleotídica) dentro do locus da ORF K12 do HHV-8. Foram excluídos da Tabela 21 somente os SNPs comuns a sequências de HHV-8 de mesmo genótipo, a fim de descartar assinatura genotípica na avaliação de variabilidade.

Tabela 21 - Distribuição do número de sequências de DNA de HHV-8 positivas para determinado SNP com base na posição nucleotídica do genoma de referência do GenBank U75698.

\begin{tabular}{|c|c|c|c|c|c|c|c|}
\hline \multirow{2}{*}{$\begin{array}{c}\text { Coordenada } \\
*\end{array}$} & \multicolumn{2}{|l|}{ SNP } & \multicolumn{3}{|c|}{ Estudo Atual (n) } & \multirow[b]{2}{*}{ Total } & Outros* \\
\hline & Posição nt & $\begin{array}{c}\text { SNP } \\
\text { (troca nt) }\end{array}$ & $\begin{array}{c}\text { Grupo } 1 \\
\text { SK }\end{array}$ & Total & $\begin{array}{c}\text { Grupo } 2 \\
\text { nSK }\end{array}$ & & $\begin{array}{c}S K \\
n=20\end{array}$ \\
\hline 1 & 117417 & $A-C$ & 1 & 8 & 0 & 19 & 0 \\
\hline 2 & 117417 & $A-G$ & 1 & 8 & 4 & 19 & 4 \\
\hline 3 & 117423 & G-A & 5 & 8 & 0 & 11 & 1 \\
\hline 4 & 117437 & A-T & 0 & 10 & 0 & 28 & $1^{* *}$ \\
\hline 5 & 117438 & T-A & 0 & 11 & 0 & 27 & $1^{* *}$ \\
\hline 6 & 117453 & $A-T$ & 0 & 11 & 1 & 27 & 0 \\
\hline 7 & 117454 & C-A & 0 & 11 & 1 & 27 & 0 \\
\hline 8 & 117465 & G-T & 1 & 11 & 4 & 27 & 0 \\
\hline 9 & 117476 & $T-G$ & 1 & 11 & 0 & 27 & 0 \\
\hline 10 & 117482 & $C-G$ & 1 & 11 & 0 & 27 & 0 \\
\hline 11 & 117484 & $A-G$ & 2 & 11 & 1 & 27 & 0 \\
\hline 12 & 117486 & $A-G$ & 1 & 11 & 0 & 27 & 0 \\
\hline 13 & 117502 & C-G & 0 & 11 & 3 & 27 & 6 \\
\hline 14 & 117528 & G-A & 0 & 11 & 0 & 27 & 7 \\
\hline 15 & 117529 & $A-G$ & 1 & 11 & 0 & 27 & 0 \\
\hline 16 & 117530 & G-A & 1 & 11 & 1 & 27 & 0 \\
\hline 17 & 117545 & C-T & 0 & 11 & 0 & 27 & 1 \\
\hline 18 & 117549 & $A-G$ & 1 & 11 & 0 & 27 & 0 \\
\hline 19 & 117550 & G-C & 4 & 11 & 9 & 27 & 9 \\
\hline 20 & 117552 & $A-G$ & 3 & 11 & 6 & 27 & $2^{* *}$ \\
\hline 21 & 117578 & C-A & 3 & 11 & 6 & 27 & 0 \\
\hline 22 & 117588 & C-T & 1 & 14 & 1 & 28 & 0 \\
\hline 23 & 117603 & $A-G$ & 5 & 14 & 9 & 28 & $11^{* *}$ \\
\hline 24 & 117615 & $A-G$ & 1 & 14 & 3 & 28 & 6 \\
\hline 25 & 117632 & $A-G$ & 2 & 14 & 6 & 28 & 5 \\
\hline 26 & 117662 & $\mathrm{~T}-\mathrm{C}$ & 6 & 14 & 9 & 28 & 10 \\
\hline 27 & 117673 & $A-G$ & 1 & 14 & 0 & 28 & 1 \\
\hline 28 & 117685 & C-T & 0 & 14 & 0 & 28 & 4 \\
\hline 29 & 117689 & C-A & 4 & 14 & 6 & 28 & 5 \\
\hline
\end{tabular}




\begin{tabular}{|c|c|c|c|c|c|c|c|}
\hline \multirow{2}{*}{$\begin{array}{c}\text { Coordenada } \\
*\end{array}$} & \multirow{2}{*}{$\begin{array}{c}\text { SNP } \\
\text { Posição nt }\end{array}$} & \multicolumn{4}{|c|}{ Estudo Atual (n) } & \multicolumn{2}{|r|}{ Outros* } \\
\hline & & $\begin{array}{c}\text { SNP } \\
\text { (troca nt) }\end{array}$ & $\begin{array}{c}\text { Grupo } 1 \\
\text { SK }\end{array}$ & Total & $\begin{array}{c}\text { Grupo } 2 \\
\text { nSK }\end{array}$ & Total & $\begin{array}{c}\mathrm{SK} \\
\mathrm{n}=20\end{array}$ \\
\hline 30 & 117690 & C-A & 0 & 14 & 0 & 28 & 1 \\
\hline 31 & 117695 & G-A & 2 & 14 & 6 & 28 & 0 \\
\hline 32 & 117704 & C-T & 1 & 14 & 0 & 28 & 2 \\
\hline 33 & 117765 & $A-C$ & 1 & 14 & 0 & 28 & 1 \\
\hline 34 & 117805 & C-A & 1 & 14 & 0 & 28 & 0 \\
\hline 35 & 117807 & G-A & 2 & 14 & 0 & 28 & 0 \\
\hline 36 & 117866 & $\mathrm{C}-\mathrm{T}$ & 0 & 14 & 0 & 28 & 3 \\
\hline 37 & 117884 & $\mathrm{C}-\mathrm{T}$ & 6 & 14 & 10 & 28 & 10 \\
\hline 38 & 117889 & G-C & 1 & 14 & 0 & 28 & 0 \\
\hline 39 & 117892 & $\mathrm{C}-\mathrm{T}$ & 1 & 14 & 1 & 28 & 0 \\
\hline 40 & 117907 & $A-G$ & 1 & 14 & 1 & 28 & 1 \\
\hline 41 & 117912 & $\mathrm{~T}-\mathrm{C}$ & 4 & 14 & 9 & 28 & $12^{* *}$ \\
\hline 42 & 117928 & $A-T$ & 1 & 14 & 0 & 28 & 0 \\
\hline 43 & 117931 & C-T & 0 & 14 & 0 & 28 & 1 \\
\hline 44 & 117934 & $\mathrm{~T}-\mathrm{C}$ & 7 & 14 & 10 & 28 & $13^{\star *}$ \\
\hline 45 & 117937 & $C-G$ & 2 & 14 & 9 & 28 & 5 \\
\hline 46 & 117941 & G-A & 0 & 14 & 0 & 28 & 1 \\
\hline 47 & 117966 & $\mathrm{~T}-\mathrm{G}$ & 1 & 14 & 3 & 28 & 0 \\
\hline 48 & 117968 & G-T & 1 & 14 & 0 & 28 & 0 \\
\hline 49 & 117972 & C-T & 1 & 14 & 0 & 28 & 0 \\
\hline 50 & 117973 & A-T & 3 & 14 & 0 & 28 & 0 \\
\hline 51 & 117975 & $T-G$ & 0 & 14 & 1 & 28 & 0 \\
\hline 52 & 117996 & $T-G$ & 0 & 14 & 1 & 28 & 0 \\
\hline 53 & 117994 & G-A & 0 & 14 & 1 & 28 & 0 \\
\hline 54 & 117996 & G-A & 0 & 14 & 1 & 12 & 0 \\
\hline 55 & 117997 & G-A & 0 & 12 & 1 & 26 & 0 \\
\hline 56 & 118026 & $A-C$ & 0 & 10 & 1 & 27 & 16 \\
\hline 57 & 118027 & C-A & 0 & 10 & 0 & 27 & 16 \\
\hline 58 & 118036 & G-A & 5 & 6 & 5 & 22 & 0 \\
\hline \multirow[t]{2}{*}{59} & 118055 & $A-G$ & 5 & 8 & 7 & 27 & 0 \\
\hline & Total & & 91 & & 137 & & 157 \\
\hline
\end{tabular}

*SNPs presentes em sequências de HHV-8 de 20 exemplares do GenBank, provenientes de lesões de sarcoma de Kaposi clássico, endêmico e epidêmico (códigos das referências foram listados na Tabela 5). ${ }^{* *}$ contexto HHV-8 assintomático do Equador. nt = nucleotídeo.

As posições dos SNPs presentes nas regiões codificadoras de microRNA das sequências de HHV-8 aqui estudas foram: 117704 (na região que codifica miR12-12), 117972, 117973 e 117975 (na região que codifca miR10-10b), 118026 e 118027 (na região codifcara de miR12-10a*). 
O SNP (C-T ou C-A) na posição 117704 foi presente em duas sequências protótipos de origem africana (Quênia e Uganda) e em um exemplar do atual estudo (SKL50), todos com SK.

O SNP na posição 117972 (C-T) e o SNP na posição 117973 (A-T), ambos foram presentes na sequência da amostra SKL59, e o último na amostra SKL63, ambos do grupo 1 com SK. Os SNPs nas posições 117975 (T-G) e 118026 (A-C) foram presentes nas sequências de código nFOX696 e nFOX58, respectivamente, ambas do grupo 2-nSK sem SK. O SNP na posição 118026 também foi observado também em sequências de 16 protótipos de diferentes regiões em indivíduos com SK. O SNP 118027 não foi detectado em nenhuma sequência de HHV-8 desse estudo, porém foi presente em 16 protótipos com SK.

Contudo, dos 6/59 sítios polimórficos em regiões codificadoras de miRNA, 4/59 (66\%) foram exclusivamente presentes no grupo SK e sequências protótipos de SK clássico, epidêmico e endêmico. A frequência desses SNPs em regiôes codificadoras de miRNA foi de 4/14 (21\%) no grupo SK e 2/28 (7\%) no grupo sem SK $(p=0,15)$.

O protótipo representante de caso assintomático (protótipo HUA_5) apresentou seis SNPs: nas posições 117437, 117438, 117552, 117603, 117912, 117934, igualmente presentes em sequências de HHV-8 do grupo 1 e 2.

\subsubsection{Mutações nas sequência de aminoácidos do locus K12}

A Figura 24 apresenta o alinhamento das sequências de aminoácidos do locus K12 de HHV-8 desse estudo (grupo 1 e grupo 2) e protótipos. Nota-se que a sequência é restrita a 60 aminoácidos (Kaposina). As posições com mais de dois aminoácidos divergentes, verticalmente observadas no alinhamento das sequências de HHV-8, foram presentes em $8 \%(5 / 60)$ dos 60 sítios. O códon 59 com o aminoácido $\mathrm{E}$ (ácido glutâmico) foi presente apenas nas sequências de HHV-8 do locus K12 das amotras 
desse estudo ( $n=09$ ), em três casos do grupo 1 e seis do grupo 2; esses foram pertencentes ao mesmo clado na reconstrução filogenética do locus K12, genótipo $B$.

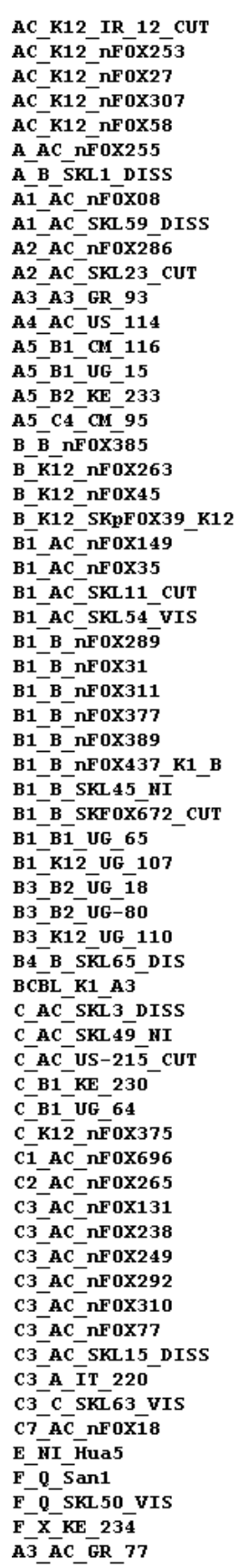



Figura 24 - Conjunto das sequências de aminoácidos do locus K12 dos grupos 1 e 2 e protótipos de diferentes regiões geográficas. Sequências foram precedidas à esquerda pela sua identificação: primeira letra indica o genótipo K1 de cada sequência (quandor houver), e a seguir, o genótipo dado pela análise do locus K12 mais o código da amostra. Amostras SKL1, SKL54, nFOX77 não apresentaram sequências de HHV-8 correspondente a dada região codificadora da Kaposina (60 aminoácidos). 
O atual estudo possibilitou identificar os genótipos e subgenótipos de HHV-8 por meio da análise da sequências da ORF K1 e ainda possibilitou descrever polimorfismos em regiões codificadoras de microRNA do gene da Kaposina (ORF K12), em um total de 75 indivíduos infectados por HIV com SK e sem histórico de SK, na era de alta e baixa incidência de SK-epidêmico, ambos sobre interferência do uso de HAART.

A primeira contribuição adicional do nosso estudo em relação ao estudos anteriores no Brasil, foi apresentar a análise de sequências completas do locus K1 de HHV-8. Essa estratégia permitiu apresentar evidências de eventos de recombinação, particularmente no grupo 2-nSK. A segunda contribuição que destacamos foi a identificação de um grande repertório de genótipos e subgenótipos de HHV-8, os quais foram obtidos por meio de um conjunto de diferentes primers na amplificação do locus K1 completo e das regiões parciais hipervariáveis VR1 e VR2, simultâneamente. Com essa estratégia foi possível identificar a variabilidade genotípica de HHV-8 na saliva e CMSP de indivíduos infectados por HIV.

As sequências do HHV-8 analisadas confirmaram propriedades importantes do genoma de HHV-8 descritos previamente: a presença marcante de mutações não silenciosas na ORF $\mathrm{K} 1$, tanto nas sequências protótipos e igualmente nas sequências de HHV-8 obtidas aqui (Figura 22); ampla associação filogeográfica de isolados HHV-8 circulantes no Brasil com sequências prototípicas de diferentes origens (Figura 16 e 17); o peculiar padrão de variabilidade da ORF K1 não observado na ORF K12, que demonstrou a diferencial taxa evolutiva que pode haver entre os segmentos do genoma do HHV-8, e ainda a presença de recombinantes (Poole et al., 1999; Hayward e Zong, 2007).

Outrossim, analisamos a variabilidade genética do locus $\mathrm{K} 12$ das sequências de DNA de HHV-8 do grupo 1-SK e grupo 2-nSK e protótipos, por meio da identificação de SNPs, em regiões codificadoras de microRNA. Essa abordagem tem obtido emergente importância, em virtude da descoberta de RNAs funcionais não 
codificadores expressos por HHV-8 (Grundhoff et al., 2006; Pfeffer et al., 2005; Marshall et al., 2010; Grundhoff et al., 2011; Gottwein, 2012). A presença de microRNA foi detectada nos herpesvírus, e trabalhos posteriores começaram a apontar a associação da presença de SNPs nas regiões codificadoras de pre-miRNA (do locus da ORF K12 e região intergênica adjacente) com potencial valor clínico (Marshall et al., 2010; Ray et al., 2012; Han et al., 2013).

São ainda escassas as investigações sobre variabilidade genética do HHV-8 no Brasil (Ishak et al., 2007; Ramos da Silva et al., 2011; Leão et al., 2013). Uma das casuísticas mais significativas foi de Nascimento et al, 2005, que estudou 33 casos de SK-aids e detectaram os genótipos A, B e C em biópsia e os subgenótipos $A 1, A 3, A 5, B 1, C 2, C 3$ de HHV-8, restrito ao locus K1/VR1 e poucas sequências do locus K1/VR2. Ainda, no Brasil, Santos-Fortuna (2005) detectou diferentes ORFs de HHV-8 em diferentes materiais biológicos, mas obteve detecção positiva de DNA/K1/HHV-8 em número restrito de indivíduos HIV/aids sem SK (2/19) na saliva; a maior positividade de DNA/HHV-8 foi obtida a partir da ORF 26, ORF8.1 e ORF73, as quais não são apropriadas para os estudos de genotipagem. Ramos da Silva et al. (2005) relataram o predomínio dos genótipos C e A de HHV-8, em SK clássico e epidêmico, respectivamente, em 50 biópsias de SK. Outros estudos foram baseados em análise de CMSP ou saliva de grupos indígenas da amazônia brasileira em que a manifestação de SK não foi descrita (Biggar et al., 2000; Borges et al., 2012).

A Tabela 22 apresenta alguns dos principais estudos sobre a variabilidade genética do HHV-8 baseada no locus K1, de diferentes regiões, inclusive do Brasil, apontando a casuística, fonte de material biológico e o tamanho de fragmento de DNA de HHV-8 sequenciado. Nota-se que ainda a abordagem é restrita no Brasil em relação a essas características. E ainda, podemos notar que o estudo atual é o primeiro estudo brasileiro a analisar sequência completa do locus K1. Foram 13 sequências completas e 45 parcias do locus K1 para o grupo 1-SK e 19 sequências completas e 46 parcias do locus K1 do grupo 2-nSK. 
Tabela 22 - Alguns principais estudos sobre a variabilidade genética do HHV-8 baseada no locus $\mathrm{K} 1$, de diferentes regiões do mundo, inclusive do Brasil, apontando a casuística e o tamanho de fragmento de DNA de HHV-8 sequenciado.

\begin{tabular}{|c|c|c|c|c|c|}
\hline $\begin{array}{l}\text { Número } \\
\text { de } \\
\text { casos }\end{array}$ & $\begin{array}{c}\text { Genótipos/ } \\
\text { Subgenótipos }\end{array}$ & Local & $\begin{array}{l}\mathrm{K} 1 \\
\mathrm{pb}\end{array}$ & $\begin{array}{l}\text { Material } \\
\text { Biológico }\end{array}$ & Referência \\
\hline 63 & $\mathrm{~A} 1-\mathrm{A} 5, \mathrm{C} 1-\mathrm{C} 4, \mathrm{~B}$ & $\begin{array}{c}\text { Guiana Francesas, Itália, } \\
\text { Espanha }\end{array}$ & 870 & Tec. paraf. & $\begin{array}{l}\text { Poole et al., } \\
1999\end{array}$ \\
\hline 62 & $A, B, C$ & Europa, África & $\sim 300-900$ & $\begin{array}{l}\text { Tec. paraf/ } \\
\text { CMSP }\end{array}$ & $\begin{array}{l}\text { Cook et al., } \\
1999\end{array}$ \\
\hline 49 & $\begin{array}{c}\mathrm{A}, \mathrm{A} 2, \mathrm{~A} 3, \mathrm{~A} 5, \mathrm{~B}, \mathrm{~B} 1, \mathrm{~B} 2, \mathrm{~B} \\
2, \mathrm{C}\end{array}$ & $\begin{array}{c}\text { Africa, Guiana Francesa, } \\
\text { Europa e Ásia }\end{array}$ & 870 & biopsia & $\begin{array}{l}\text { Lacoste et al., } \\
2000 \mathrm{a}\end{array}$ \\
\hline 4 & A5,B & Africa e Guiana Francesa & 870 & $\begin{array}{l}\text { biopsia/ } \\
\text { CMSP }\end{array}$ & $\begin{array}{l}\text { Fouchard et al., } \\
2000\end{array}$ \\
\hline 32 & $\mathrm{~A} 5, \mathrm{~B} 1, \mathrm{~B} 2, \mathrm{C}$ & Africa & 650 & CMSP & $\begin{array}{l}\text { Kajumbula et al., } \\
2006\end{array}$ \\
\hline 170 & $\mathrm{~B}, \mathrm{~A} 5$ & Africa (Botswana) e Equador & 868 & CMSP & $\begin{array}{l}\text { Whitby et al., } \\
2004\end{array}$ \\
\hline 33 & $\begin{array}{c}A, A 1, A 5, A 6, B, B 1, \\
C, C 2, C 3\end{array}$ & Brasil (São Paulo) & $\sim 350$ & biopsia & $\begin{array}{l}\text { Nascimento et } \\
\text { al., } 2005\end{array}$ \\
\hline 35 & $\mathrm{~A}, \mathrm{C} 1, \mathrm{C} 2, \mathrm{C} 3, \mathrm{C} 5, \mathrm{C} 7$ & Marracos (Maghreb) & 870 & biopsia & $\begin{array}{l}\text { Duprez et al., } \\
2006\end{array}$ \\
\hline 7 & $B, C, E$ & Brasil (Pará) & 435 & CMSP & $\begin{array}{l}\text { Ishak et al., } \\
\quad 2007\end{array}$ \\
\hline 68 & $A, C$ & Japão & 160 & Tec. paraf & $\begin{array}{l}\text { Kanno et al., } \\
2010\end{array}$ \\
\hline 32 & D & Malanesia (Vanatu) & 737 & CMSP & $\begin{array}{l}\text { Cassar et al., } \\
2007\end{array}$ \\
\hline 65 & A1-A5, B1-B4 & Africa (Zimbawe) & 870 & $\begin{array}{l}\text { Plasma/ } \\
\text { CMSP }\end{array}$ & $\begin{array}{l}\text { White et al., } \\
2008\end{array}$ \\
\hline 27 & $A, C, C 2$ & China & 363 & Tec.paraf & $\begin{array}{l}\text { Zhang et al., } \\
\quad 2008\end{array}$ \\
\hline 42 & $\begin{array}{c}\text { A1-A5, B1, B3, C, C1, } \\
\text { C3, F }\end{array}$ & África, Itália, Grécia, EUA & 1035 & biopsia & $\begin{array}{l}\text { Tornesello, et } \\
\text { al., } 2010\end{array}$ \\
\hline 29/35 & $\mathrm{A} 3, \mathrm{~A} 4, \mathrm{C} 1, \mathrm{C} 3$ & Itália & 422 & $\begin{array}{l}\text { CMSP/ } \\
\text { saliva }\end{array}$ & $\begin{array}{l}\text { Mancuso et al., } \\
2011\end{array}$ \\
\hline 50 & $A, B, C$ & Brasil (São Paulo) & 247 & Tec. paraf & $\begin{array}{l}\text { Ramos da Silva } \\
\text { et al., } 2011\end{array}$ \\
\hline 14 & $\mathrm{~A}, \mathrm{C} 1, \mathrm{C} 2, \mathrm{C} 3, \mathrm{C} 5, \mathrm{C} 7$ & Iran (Tehran) & $400 / 369$ & Tec. paraf & $\begin{array}{l}\text { Azadmanesh et } \\
\text { al., } 2012\end{array}$ \\
\hline 90 & $\mathrm{~A} 1-\mathrm{A} 5, \mathrm{~B}, \mathrm{C}, \mathrm{E}$ & Cuba & 621 & biopsia & $\begin{array}{l}\text { Kouri et al., } \\
2012\end{array}$ \\
\hline 29 & $\mathrm{~A} 1, \mathrm{~A} 3, \mathrm{~A} 4, \mathrm{C} 1, \mathrm{C} 2, \mathrm{C} 3$ & Europa & 1065 & CMSP & $\begin{array}{l}\text { Marshall et al., } \\
2013\end{array}$ \\
\hline
\end{tabular}

À medida que mais sequências de HHV-8 são descritas, maior a possibilidade de detecção de novas variantes virais e, consequentemente melhor a interpretação de eventos até agora pouco esclarecidos sobre o potencial patogênco associado ao genótipo do HHV-8 e transmissibilidade do vírus. A atual classificação dos isolados de HHV-8 é considerada ainda provisória e provavelmente deve ser modificada à medida 
que novas descrições de variantes de HHV-8 de diferentes áreas geográficas forem incluídas (Duprez et al, 2006, Cook et al, 1999, Lacoste et al, 2000a).

Atualmente, estão descritas 2.840 sequências nucleotídicas de HHV-8, dois genomas completos e 98 genes. No caso de um vírus cuja a identidade genotípica tem sido mais claramente relacionada a um potencial prognóstico para o desenvolvimento de doença, por exemplo, o vírus da Hepatite $C$, já foram descritas até momento 109.623 sequências nucleotídicas (http://www.ncbi.nlm.nih.gov/Taxonomy, acesso em 26 de julho de 2013). A despeito do genoma do HHV-8 apresentar maior complexidade, inclusive em tamanho, cerca de $140 \mathrm{~Kb}$, o entendimento do seu genoma tem trazido cada vez mais descobertas importantes para oncologia viral, desde sua descoberta há menos de 20 anos.

Uma das questões atuais está relacionada às complicações da infecção prolongada por HIV que pode resultar na condição descrita por muitos autores: a reativação e persistência de SK mesmo sob o uso de HAART, mediante contagem de CD4 acima dos valores relacionados à suscetibilidade aos agentes oportunistas e carga viral de HIV indetectável, que parece não ser um evento raro (Maurer et al., 2007; Nguyen et al., 2008; Krown et al., 2008; Stebbing et al., 2008). O aumento da sobrevida desses pacientes após a era HAART tem levado a preocupação com as consequências da infecção prolongada por HIV no desenvolvimento de câncer (Brasil, 2012), em vitude da senescência imunológica prematura que pode acelerar o curso de doenças cancerígenas, inclusive não associadas à aids (Derhovanessian et al., 2008; Appay et al., 2007).

Vale discutir incialmente o contexto da seleção dos grupos de indivíduos infectados por HIV estudados e do material biológico para o sequenciamento de DNA do HHV-8 desse trabalho que, pelo nosso conhecimento, ainda não há estudos prévios no Brasil que compararam a variabilidade genotípica de HHV-8 entre indivíduos infectados por HIV com SK e sem histórico de SK. 
Em 1998/1999, ocasião em que os indivíduos infectados por HIV com SK do grupo 1 participaram desse estudo, Pierrotti (2004) em sua tese de doutorado relatou que haviam 46 pacientes com SK em acompanhamento ambulatorial na "Casa da aids" (São Paulo). Segundo o Ministério da Saúde do Brasil, entre 1988 e 2000, foram notificados $4,2 \%$ de casos de SK em indivíduos infectados por HIV (Brasil, 2005).

Em plena era HAART, ocasião em que o grupo de indivíduos infectados por HIV sem SK participaram do estudo (ano 2007), o número de casos novos de SK registrado em São Paulo foi de 46 casos/ano; um ano antes, em 2006, foi de 52 casos/ano; em 2009 foi de 59 casos/ano e em 2010 foi de 32 casos/ano (São Paulo, 2010). A maioria dos indivíduos (92\%) do grupo 2 sem SK desse estudo foi infectada por HIV entre 1987 a 2003, e nesse período até o momento desse estudo, não apresentaram SK.

O número de mulheres foi restrito tanto no grupo com SK (3/34) quanto no grupo sem SK (3/41). Assim, todas as formas de SK predominam no sexo masculino, numa porporção que tem variado nos útimos anos. Em 1996, a proporção entre homens e mulheres com SK foi de 15: 1 (Montagnino et al., 1994). Segundo recentes registros de câncer da base de dados populacional de São Paulo, a proporção de SK entre homens e mulheres tem variado de 6:1 a 3:1 entre os anos de 2006 a 2010 (São Paulo, 2010).

Portanto, a seleção dos grupos para análise da variabilidade genética foi baseada numa casuística restrita, porém representa o contexto da infecção por HIV na era HAART em uma unidade de saúde em São Paulo, Brasil.

A busca de DNA de HHV-8 em diferentes materiais biológicos tem sido explorada por muitos autores. Desde 1995, a prevalência da infecção por HHV-8 pode ser identificada pela detecção do DNA viral por PCR em biópsia de tecido (Boshoff et al., 1995; Dupin et al., 1995; Chang et al., 1996) e nested PCR em CMSP (Moore et al., 1996b; Ishak et al., 2007) e especialmente a saliva na era 
HAART em indivíduos com e sem SK (Blackbourn et al., 1998; de Souza et al., 2007b; de França et a., 2011; Del Mistro et al., 2012; Di Alberti et al., 1997; Miller et al., 2006; Casper et al., 2007). Todavia, a maioria dos estudos analisou sequências de DNA de HHV-8 em biópsia de SK, que é um material rico em número de cópias (64.000 cópias/ $\mu \mathrm{g}$ ) de HHV-8 (LaDuca et al., 1998), mas a qualidade do DNA obtido é um fator limitante (Tamburro et al., 2012). A eficiência para a detecção de DNA de HHV-8 em CMSP especialmente em indivíduos com SK ativo tem sido bem documentada (Moore et al., 1996b; Tamburro et al., 2012; Mancuso et al., 2011), assim como a integridade do material genético viral é melhor mantida em CMSP, conforme demonstrado em estudos de viroma (Tamburro et al, 2012). Diante desse fato, julgamos ser pertinente o uso de CMSP criopreservadas que dispomos no banco de material biológico do IMTSP para o estudo da variabilidade genética do HHV-8 desses indivíduos infectados por HIV com SK (grupo 1 - SK). O critério de inclusão para o grupo 1 - SK foi baseado na obtenção de sequências dos loci K1 e/ou K12 do HHV-8 em CMSP, em que observamos uma positividade de $89,2 \%$ (33/37) e 37,85 (14/37), respectivamente, e em apenas uma amostra foi possível isolar sequência de DNA exclusivamente para o locus K12.

A detecção de DNA de HHV-8 salivar no grupo de indivíduos infectados por HIV sem SK foi a opção para o estudo atual, visto que foi anteriormente demonstrada a melhor sensibilidade para detecção de DNA de HHV-8 na saliva do que em CMSP ou sangue diante de infecção assintomática por HHV-8 em HSH infectados por HIV, que pode ser indetectável na maioria das vezes em CMSP e detectável na saliva (Miller et al., 2006; Casper et al., 2004). Os indivíduos sem SK do grupo 2-nSK apresentaram níveis detectáveis de DNA de HHV-8 salivar que variaram de 4 a 6 milhões de cópias por $\mu$ g de DNA, sem que houvesse associação entre carga viral de HHV-8 e genótipos de HHV-8 $(p=0,77)$.

A escolha do PCR em tempo real em nosso estudo foi uma vantagem que veio de encontro a nossa proposta em selecionar os indivíduos sem SK com 
infecção por HHV-8 pela detecção positiva de DNA/HHV-8 a partir de um número razoável de casos $(n=751)$. Foi encontrado 14\% (106/751) de positividade de DNA de HHV-8 da ORF 73 por PCR em tempo real para constituir o grupo 2-nSK. Esses dados foram consistentes com a margem de positividade de estudos anteriores (15$22 \%$ ) em grupos de indivíduos infectados por HIV sem SK e com igual metodologia (Casper et al., 2004); ainda que se deva considerar a dinâmica da excreção intermitente do vírus na saliva (Casper et al, 2007; Zong et al., 2007), visto que aqui nos restringimos a uma única coleta de saliva por paciente.

Foi possível determinar a sequências de DNA de HHV-8 em 32\% (34/106) para o locus $\mathrm{K} 1$ e em 26,4\% (28/106) para o locus $\mathrm{K} 12$ do HHV-8, e foram isoladas sequência de DNA de HHV-8 exclusivamente do locus $\mathrm{K} 12$ em sete amostras, totalizando 41 sequências de DNA de HHV-8 do locus K1 ou K12. Foram três nested PCR desenvolvidos simultaneamente com as mesmas amostras para obtenção das sequências do locus K1 (6 pares de primers) e 1 nested PCR para o locus $\mathrm{K} 12$, com o segundo round com um primer alternativo, daí a diferença de sensibilidade para detecção dos fragmentos da ORF K1 e K12.

Os estudos têm avaliado a sorologia para a triagem da infecção por HHV-8 com sensibilidade que varia de menos de $50 \%$ a $98 \%$ (Nascimento et al, 2007). Mas, no contexto HIV seu uso pode ser tornar limitado, em virtude da deficiente resposta imune dos pacientes, que pode interferir na produção de anticorpos, e resultar na identificação de falsos negativos diante de níveis persistentemente baixos de CD4+, conforme demonstrado por Souza et al., 2007a. Por isso, o estudo atual se baseou na seleção dos indivíduos infectados por HHV-8 sem SK para compor o grupo 2 nSK por meio da ferramenta molecular (PCR em tempo real da ORF 73/HHV-8), visto que o objetivo principal foi obter sequências de DNA de HHV-8, além de não disponibilizarmos de soros coletados na mesma ocasião de todos os indivíduos.

Em estudos anteriores da sorologia desses indivíduos (dados não publicados), dos 106 indivíduos avaliados para a composição do grupo 2 - nSK com amostra de soro disponível no banco de material biológico, a positividade foi de 
$88 \%$, sendo $73 \%$ e $77 \%$ para anticorpos da fase latente e lítica do HHV-8, respectivamente. No grupo $1-\mathrm{SK}$, foi de 70 e $90 \%$, para anticorpos da fase latente e lítica, respectivamente, em 21 casos com soros disponíveis. A sorologia negativa com detecção de DNA/HHV-8 positiva foi obtida em 5/41 casos com genótipos $A$, B ou C de HHV-8 e com carga viral de HHV-8 de 4 a 28 mil cópias por $\mu g$ de DNA. Descartamos a possibilidade de falso positivo da PCR, visto que os cuidados para evitar a contaminação foram rigorosamente tomados e o monitoramento desses procedimentos foi avaliado continuamente com controles negativos intercalados entre as amostras que foram confirmados em todos os passos. A soronegatividade para HHV-8 pareada com detecção positiva de DNA de HHV-8 tem sido questionada em estudos incluindo indivíduos imunocompetentes (Zong et al, 2007), por motivos que julgamos não se aplicar ao nossos resultados.

Contudo, não foi possível obter positividade na nested PCR para detecção de DNA HHV-8 (ORF K1 e K12) nas salivas de 62/106 indivíduos, portanto não foram incluídos no estudo. Desses, um total de $46 \%$ apresentaram em média carga viral de HHV-8 de 137 cópias virais por $\mu$ de DNA (em torno de 4 a 980 cópias por $\mu \mathrm{g}$ de DNA). A carga viral baixa pode reduzir, embora não excluir, a chance de amplificação de cópias virais por nested PCR, considerando a maior sensibilidade da PCR em tempo real em relação à nested PCR em detectar pequenas quantidades de DNA viral.

Entretanto, a falta de obtenção de positividade da PCR diante da carga viral de HHV-8 detectável, a despeito da carga viral baixa ou não, pode estar associada à presença de sequências virais com divergência na região de pareamento dos primers. Buscamos evitar tal ocorrência pela estratégia de uso de seis pares de primers em posições do locus K1 (completo e parcial) que pudessem evitar viés de amplificação, sem os quais poder-se-ia resultar na chance de subestimar ou superestimar genótipos virais. Porém, a ORF K12 é relativamente conservada e a ORF K1 é hipervariável, a ponto de não se excluir que em ambas as regiões haja, 
em menor ou maior grau, a possibilidade de que variantes ainda não reconhecidas existam, como discutiremos a seguir.

\section{Os genótipos e subgenótipos de HHV-8 foram investigados} preferencialmente através da análise do locus da ORF K1, cuja hipervariabilidade tem favorecido a identificação dos principais genótipos virais já descritos. No Brasil, os estudos de genotipagem do HHV-8 mais atuais se basearam na análise de sequências curtas de duas regiões hipervariáveis do locus K1 (VR1 e VR2), e identificaram os genótipos A, B e C de HHV-8 (Nascimento et al., 2005, Ishak et al., 2007; Ramos da Silva et al., 2011) em biópsias de SK. Ao contrário de nossos resultados, o genótipo $B$ foi minoritariamente detectado em alguns desses estudos em casos de SK-aids no Brasil, tendo sido o genótipo B detectado em torno de 2 a $21 \%$, enquanto o genótipo ou subtipo A foi em torno de $50 \%$ e o subtipo C foi de 30 a 48\% (Nascimento et al., 2005; Ramos da Silva et al., 2011). Nossos dados apontaram uma frequência do genótipo A de 12 a $24 \%$ e dos genótipos B e C em torno de 35\% com um sistema de primers, que inclue os primers empregados por Nascimento et al, 2005. A discrepância observada particularmente entre as frequências do genótipo ou subtipo B entre os estudos, levou-nos a supeitar se os primers utilizados nesses estudos foram apropriados.

A despeito da relação etnogeográfica que aponta a diferença de frequência de certos genótipos de HHV-8 em determinadas regiões ou grupos étnicos ou da fonte do material biológico em que um dado genótipo pode ser mais facilmente detectado, notamos que, a escolha de uma sonda (primer) pode subestimar a detecção de um dado genótipo.

A existência de divergência nas sequências de DNA na região dos sondas iniciadoras (primers) foi observada no alinhamento de sequências de HHV-8 prototípicas (Figura 15). Obervamos que particularmente sequências protótipos de HHV-8 com genótipo B e variantes apresentaram divergência de nucleotídeos na referida região de pareamento dos primers $V R 2$, especialmente na região mediana e 
proximal à porção 3', que deve associar-se a enzima Taq polimerase no momento da síntese da nova molécula do DNA. Presumivelmente, gerando a falha de detecção de um dado genótipo e suas variantes.

Estudos que limitaram a análise de genótipos de HHV-8 com apenas o uso de primer para regiões parciais de K1 (especialmente, primers Kinn5 ou LGH 2090 da região VR2) (Ramos da Silva et al., 2011; Santos Fortuna, 2005; Nascimento et al.,2005) presumivelmente subestimaram a detecção do genótipo B e seus subgenótipos ou suas variantes. Contudo, sugerimos que a diferencial frequência do genótipos B em alguns estudos seja devido a escolha limitada de um sistema de primers para obtenção de sequências VR1 ou VR2, e recomendamos que primers complementares alternativos dirigidos à região VR2 sejam incluídos.

Os protótipos do genótipo B que apresentaram essa divergência de nucleotídeos puderam ter suas sequências obtidas com primers distintos (Cook, et al., 1999; Lacoste et al., 2000a; Kakoola, et al., 2001). Outrossim, Zong et al, 1999, empregaram o primer anteriormente citado (LGH2090), porém, com um conjunto de mais 8 primers em posições genômicas que permitiram a esses autores cobrir todos ou a maioria dos genótipos e subgenótipos de HHV-8.

Estudos de genotipagem do HHV-8 da América do sul limitaram suas análises à região parcial de K1 (Meng et al., 2001; Kouri et al., 2005; Nascimento et al., 2005; Ishak et al., 2008; Kouri et al., 2012), cujo pareamento desses se dá em trechos de sequências de DNA de HHV-8 que divergem, conforme demonstrado (Figura 15) em relação a alguns protótipos dos genótipos e subgenótipos de B, C, D, E e suas variantes.

Kasolo et al. (1998) descreveram a presença específica do genótipo A5 do HHV-8 em 15 crianças febris em Zambia, na África, e nenhum genótipo B. Com os primers empregados nesse estudo, provavelmente não foram capazes de amplificar o genótipo ou subtipo B na reduzida casuística. Mais tarde, Kasolo et al. (2007), ao contrário da interpretação anterior, demonstraram em 200 crianças de regiâo 
endêmica de SK, que há pouca restrição de genótipos na transmissão infantil do HHV-8 em relação aos adultos, inclusive detectaram significativa presença do genótipo B.

Kouri et al., 2005 relataram baixa frequência do genótipo ou subtipo B em Cuba, mas posteriormente, em estudo apresentado em 2012 (Kouri, et al., 2012), os autores demonstraram a mudança temporal da frequência do subtipo $B$, em virtude da migração africana. É amplamente plausível que a migração africana tenha exercido influência para a mudança temporal da frequência do genótipo B em Cuba. No entanto, presumivelmente haveria menos chances de detectar o genótipo B com os primers utilizados por esses autores.

Ressaltamos uma vantagem conferida ao uso do protocolo do estudo atual, que foi baseado no locus K1 completo além das regiões parciais VR1 e VR2 para que possamos buscar cobrir os genótipos e subgenótipos do HHV-8 conhecidos. Assim, associamos o melhor desempenho de amplificação de fragmentos menores (melhor sensibilidade) com o melhor poder de identificação das características em sequências completas (genótipos, subgenótipos, recombinações), de modo a pesquisar a variabilidade da ORF K1 nos três níveis previamente definidos por Hayward, 1999. O primeiro e mais antigo nível de variabilidade é observado ao longo de todo do gene $\mathrm{K} 1$, que define os subtipos ou genótipos. O segundo, e mais recente nível é observado entre (intertipos) e dentro (intratipos) dos subtipos, sendo limitado em dois blocos de 40 aminoácidos referidos como domínios VR1 e VR2, definindo os subgenótipos. O terceiro nível é encontrado em variantes de HHV-8 específicas. É uma região delimitada, hipervariável $\left(V R^{\star}\right)$, que parece sofrer mais intensa pressão positiva, e ainda parece estar correlacionada com epitopos de Células T (Stebbing et al., 2003; Zong et al., 1999, 2002).

Além de estratégias metodológicas que possam melhorar a definição e detecção de genótipos e subgenótipos de HHV-8 e evitar o viés de amplificação, alguns autores apontaram que em um determinado sítio 
anatômico (biópsia, sangue, saliva), há maior possibilidade de detectar um dado genótipo viral. Matteoli et al., 2012, destacaram a presença do subgenótipo A1 na cavidade oral mais frequentemente do que no sangue e subgenótipo C3 mais frequentemente em linhagens virais do epitélio.

Nossos dados mostraram o predomínio dos subgenótipos B1 e C3 tanto em CMSP no grupo 1-SK quanto na saliva do grupo 2-nSK. A observação parece sugerir que a via de transmissão pode envolver os subgenótipos B1 e C3 tanto no sangue quanto na saliva, visto que a transmissão via saliva como fonte de infecção do HHV-8 foi demonstrada em muitos estudos (Vieira et al., 1997; Koelle et al., 1997; Souza et al.,2007b; Borges et al., 2012; Mancuso et al., 2011), assim como o risco de transmissão sanguínea por doadores soropositivos para HHV-8 também foi demonstrado em área endêmica e não endêmica de SK (Dollard et al., 2005; Hadik et al., 2012), embora esse risco não tenha sido confirmado em banco de sangue no Brasil (Levi et al., 2012).

Observamos que um indivíduo com registro de pertencer a categorias de risco de adquirir HIV por transfusão de sangue apresentou o subgenótipo A5 de HHV-8. Dois indivíduos que relataram serem usuários de drogas injetáveis, um apresentou o subgenótipo C7 e o outro B1 do HHV-8. Os subgenótipos B2, C1, C2 e C5 foram exclusivos dos indivíduos HSH do grupo 2-nSK. Esses dados não apresentaram suporte estatístico, devido ao número restrito de casos. Porém, a transmissão desses subgenótipos de HHV-8 em HSH pode ser veículada pela saliva por práticas específicas, conforme argumentado por alguns autores que ainda apontaram que HHV-8 circula entre HSH antes da epidemia do HIV e advento da aids (Martin et al., 1998; Martin et al., 2000). O subgenótipo C2 de HHV-8 predomina no contexto de SK clássico, por meio da transmissão intrafamiliar do HHV-8 via saliva (Mancuso et al., 2011), enquanto os subgenótipo B2, C1 e C5 foram associados ao SK endêmico e SK associado à aids (Lacoste et al., 2000a; Duprez et 
al., 2006b). De fato, o conjunto desses dados sugerem que a saliva pode representar uma via importante de transmissão do HHV-8 em HSH.

Ainda, em relação ao predomínio de um dado genótipo de HHV-8, observamos que o genótipo A não foi detectado nas CMSP e nem na saliva de indivíduos com carga viral de HIV baixa (menor que log de 3 cópias por $\mathrm{mL}$ ), portanto, sugerindo o estado de melhor prognóstico da doença clínica (Tabela 19) na ausência do genótipo A de HHV-8, embora a avaliação foi apenas transversal, com número restrito de casos, sem significado estatístico.

Os indivíduos do grupo SK apresentaram contagem de CD4 significativamente menor do que o grupo sem SK, embora também foram registrados episódio de piora de SK na ocasião da contagem de CD4 com valores acima de 350 células $/ \mathrm{mL}$, sem que pudéssemos observar relação com genótipo de HHV-8, devido ao número limitado de casos. Em áreas endêmicas, o SK ocorre mesmo sem nenhuma deficiência de células T (Kestens et al., 1985), portanto outro co-fator parece estar envolvido. Foi demonstrado que o HIV induz a replicação lítica do HHV-8, e a proteína Tat do HIV, como co-fator, aumenta a atividade de genes envolvidos na angiogenese, proliferação e replicação do HHV-8 (Aoki et al., 2007). Contudo, nunca foi investigado se algum genótipo de HHV-8 oferece alguma vantagem no desempenho da transativação HIV e HHV-8.

Estudos apontaram que no contexto da co-infecção por HIV e pelo genótipo A do HHV-8, o SK exibe características de maior gravidade (Boralevi et al., 1998). Esses dados parecem sugerir que possa haver um fenômeno de cooperação viral (HIV e HHV-8) para a progressão do SK em dependência do genótipo A do HHV-8.

Nossos dados não foram capazes de mostrar alguma relação entre os genótipos de HHV-8 e presença ou não de SK, ou estadio de SK, no entanto, observamos que o subgenótipo B1 foi predominantemente detectado no grupo 1 - SK sem registro de episódio de piora de $S K(p=0,04)$. Essa observação parece indicar que o subgenótipo B1 esteja relacionado com um melhor prognóstico 
do tumor. Além disso, foi observado que entre aqueles sem SK e sem adoecimento com aids, o genótipo A foi minoritário (1/9) e os dois registros de óbito entre aqueles com SK foram de indivíduos com genótipo não B (A1 e C3) de HHV-8.

Contudo, poucos trabalhos observaram alguma associação clara entre o potencial genotípico do HHV-8 para o prognóstico de SK. O genótipo A do HHV-8 foi associado com alta gravidade não só no contexto SK-aids, mas no SK-clássico (Luppi et al., 1997; Boralevi et al., 1998; Gazouli et al., 2004; Mancuso et al., 2008). Em contrapartida, possíveis correlações entre genótipos e diferentes níveis de gravidade da doença não foram confirmadas por outros autores (Cook et al., 1999; Lacoste et al., 2000a; Kadirova et al., 2003; Nascimento et al., 2005; Tornesello et al., 2010).

No contexto SK clássico, Mancuso et al., (2008) observaram que o genótipo A do HHV-8 foi predominante em pacientes que apresentaram rápida progressão de SK (12/17) enquanto o genótipo C foi principalmente associado à baixa progressão do SK (6/7).

Estudos apontaram que o genótipo ou subtipo $A$ teve sua maior disseminação na epidemia da aids, na Europa e nos EUA, e também nas américas (Kouri et al., 2012). Segundo Kouri et al. (2012), uma observação temporal e comportamental justificou o predomínio de um dado genótipo de HHV-8 em Cuba. Esses autores apontaram que, a partir de 2004 houve uma expansão do subtipo B em Cuba, devido a introdução de trabalhadores da África na década de 70, assim como o genótipo B também foi associado ao comportamento heterossexual. Da mesma forma, o genótipo A foi pre-existente a epidemia do HIV em Cuba, introduzido por colonizadores espanhóis, e disseminado entre os pacientes com aids há 10 a 20 anos atrás.

O perfil de subgenótipos de A do HHV-8 em CMSP no grupo -SK e a de subgenótipos de C na saliva no grupo 2-nSK foi uma informação interessante que atribuímos ao estudo atual. Embora não houvesse diferença estatística 
significativa dos genótipos de HHV-8 entre os grupos com e sem SK ( $p=0,79)$, foi possível observar um perfil de subgenótipos de $A(A 1, A 2, A 4, A 5)$ no grupo 1-SK. A maioria dos indivíduos desse grupo foi infectada por HIV após 1996 (com diagnóstico de HIV e aids entre 1987 a 1999 (Tabela 16) e apresentaram menos de 40 anos (Tabela 20). As sequências de DNA de HHV-8 foram obtidas de CMSP desses indivíduos na era de alta incidência do SK-associado à aids no início da era HAART (ano 1998-1999). Ao contrário do observado no grupo 2 - nSK, no grupo 1 - SK houve 100\% de subgenótipos B1 e C3, não havendo a presença de outros intertipos ou intratipos de B ou C no grupo 1.

Os subgenótipos A4 e A5 foram detectados exclusivamente no grupo 1 - SK. Os subgenótipo A4 de HHV-8 foi detectado em um individuo não branco em que foi registrado episódios de piora clínica de SK.

O subgenótipo A5 foi detectado nesse estudo em um indivíduo branco, do sexo feminino, com SK visceral, sem registro de piora clínica de SK. O subgenótipo A5 foi anteriormente descrito no Brasil em indivíduo negro no contexto SK-aids por Nascimento et al., 2005. De modo interessante, tem sido apontada a ocorrência do subgenótipo A5 em grupos africanos com alta incidência da doença (SK - endêmico) e, igualmente, predominante em grupos com alta incidência da infecção por HHV-8 e baixa incidência de SK (tribos indígenas do equador infectados por HHV-8 sem SK). Esse contraponto sugere que haja algum co-fator desencadeante do tumor além da infecção pelo subgenótipo A5, assim como acontece com outros genótipos do HHV8.

Diferente do grupo 1, foi observada a presença de um maior perfil de subgenótipos de B (B1 e B2) e particularmente de $C(C 1, C 2, C 3, C 5$ e $C 7)$ na saliva de indivíduos do grupo 2 - nSK, sem histórico de SK, a maioria com mais de 40 anos (Tabela 20), abordados para o estudo na ocasião de baixa incidência de SK associado ao HIV (no ano de 2007), especialmente apresentaram longo tempo de infecção por HIV. Assim como no grupo 1, a maioria foi infectada por HIV após 1996 
(com diagnóstico de HIV entre 1987 a 2003) (Tabela 17), sob longo tempo de uso antirretroviral (Tabela 18), independente da carga viral de HIV indetectável ou não (Tabela 19).

Estudos do noroeste da África da região de Manghreb (Marrocos) demonstraram igualmente grande variabilidade genética desses virus dos subgenótipos de $\mathrm{C}$, similar a encontrada aqui, pertencentes aos quatro distintos subgenótipos (C2, C3, C5 e C7) (Duprez et al., 2006). Os subgenótipos C5 e C7 de HHV-8 foram identificados previamente por Duprez et al (2006b) e foram reconhecidos como recombinantes em amostras de SK Clássico e Epidêmico, respectivamente.

Previamente, já havia sido relatada a ocorrência de genoma quimérico (Cook et al., 1999; Zong et al., 2002; Poole et al., 1999), mas poucos dados foram apresentados sobre a avaliação da origem parental e sobre a caracterização do sítio de recombinação. A posição filogenética intermediária entre $A$ e $C$ do subgenótipo C5 foi demonstrada por Zong et al, 2002. Mais tarde, Duprez et al. (2006b) demostraram o ponto de recombinação entre as sequências de DNA parentais do locus K1 de C5 e C7. Foi demonstrado por esses autores que o subgenótipo ou subtipo $C 7$ foi originado do evento de recombinação entre C3 ( $\left.C^{\prime}\right)$ e C1/C2 ( $\left.C^{\prime \prime}\right)$.

Nosso estudo confirmou esses dados por meio de programas de detecção de recombinantes (Figura 19 e 20). Em três amostras conseguimos confirmar o evento de recombinação através da análise do locus $\mathrm{K} 1$, e estes não são eventos novos, mas sim, recombinantes circulantes ja extensivamente descritos.

Embora a presença de intertipos e intratipos recombinantes pareça assumir a ocorrência de infecção dupla no mesmo hospedeiro (Beyari et al., 2003), essa observação tem sido pouco consistente na literatura. Os estudos apontaram que o fenômeno de variabilidade intrahospederio não seja comum na infecção por HHV-8 (Hayward, 1999; Hayward e Zong, 2007). A análise genotípica de múltiplos loci do genoma de HHV-8 apontaram que os eventos de recombinação ocorrem numa taxa 
muito baixa no genoma do HHV-8 (Cook et al.,1999; Poole et al., 1999; Zong et al., 2002; Hayward e Zong, 2007).

Esses estudos enfatizaram que a atual classificação dos isolados de HHV-8 ainda devam ser considerados provisórios, e é esperado que muitos possam ainda ter sua classificação modificada a medida que novas sequências de DNA/HHV-8 sejam descritas de modo abrangente nas diferentes áreas geográficas.

Um exemplo dessa limitação é dado pelo isolado K1-43/Ber, descrito como um possível HHV-8 recombinante, e agora reconsiderado como um novo genótipo, o subtipo F, descrito por Kajumbula et al., 2006.

O protótipo K1-32/Bcb AF 178799 (Lacoste et al., 2000a) foi considerado genótipo $A 3$, no entanto em virtude de sua posição intermediária, sua classificação parece questionável. Observamos que o protótipo D4-2 DQ 394038 (Marrocos), posteriormente identificado e confirmado por Duprez et al (2006b) como C5 recombinante, foi posicionado no mesmo ramo do protótipo K1-32 (Figura 16). Conforme, essas observações e como já sugerido por outros estudos (Duprez et al., 2006; Cook et al.,1999 e Lacoste et al., 2000a), um consenso sobre o critério usado para definir a nomenclatura e classificação é amplamente necessário.

A possibilidade de infecções por múltiplos genótipos em um mesmo hospedeiro que justifique a presença de recombinação não pode ser descartada, embora nossos dados não demonstraram nenhum exemplo, mesmo quando foram investigadas as sequências de DNA/HHV-8 em mais de uma amostra biológica do mesmo indivíduo. Observamos sequências de DNA de HHV-8 de alta identidade em exemplares de que dispomos de amostras pareadas de sangue (CMSP) e saliva num intervalo de 8 anos, assim como em amostras seriadas de CMSP em 5 casos em que os indivíduos tiveram de 2 a 4 coletas de sangue (Figura 16 A e 16 B, elementos sublinhados).

Enquanto estudos consistentemente demonstraram que não há variação de genótipos de HHV-8 em CMSP, biópsia, sangue e saliva entre múltiplas amostras 
coletadas do mesmo indivíduo (Hayward e Zong, 2007; Zong et al, 2007), por outro lado, também relataram que ocasionalmente há a ocorrência de sequências idênticas de DNA/HHV-8 do locus K1 entre pacientes diferentes. Segundo esses autores, no caso da infecção por outro herpesvírus, o citomegalovírus (CMV), a ocorrência de múltiplos genótipos pode ser observada, embora seja rara (Zong et al., 2007).

Não obstante os estudos de variações genotípicas de HHV-8 intrahospedeiro serem menos abordadas na literatura, esses indicaram uma ocorrência extremamente rara (Zong et al.,2002; Kajumbula et al., 2006; Zong et al., 2007; Hayward and Zong, 2007). Um estudo avaliou a variabilidade genotípica intrahospedeiro no Brasil e demonstrou que as lesões SK-aids estão associadas à infecção por uma única variante de HHV-8 ou um pequeno grupo de variantes relacionadas no mesmo hospedeiro (Leao et al., 2013).

O predomínio de um dado genótipo ou subgenótipo em determinadas áreas geográficas ou grupos étnicos é a evidência mais marcante do nível de diversidade ao longo da ORF K1, acumulado em decorrência da pressão evolutiva associada à migraçao humana.

A hipervariabilidade do locus K1 tem trazido grande suporte para aplicação nos estudos de genotipagem do HHV-8, de modo que permitiu a identificação os principais genótipos ou subtipos de $\mathrm{K} 1$ ( $\mathrm{A}, \mathrm{B}, \mathrm{C}, \mathrm{D}$ e $\mathrm{E})$, os quais exibiram um claro grupamento geográfico. Muitos estudos de epidemiologia molecular no mundo basearam-se na alta variabilidade genética do locus K1 para identificação dos genótipos de HHV-8 (Biggar et al., 2000; Cook et al., 1999; Kadyrova et al., 2003; Kakoola et al., 2001; Kasolo et al., 1998; Kazanji et al., 2005; Lacoste et al., 2000a; Lacoste et al., 2000b; Meng et al., 1999; Meng et al., 2001; Nicholas et al., 1998; Whitby et al., 2004; Zong et al., 1999; Zong et al., 2002; Tornesello, et al., 2010).

Além disso, tem-se descrito que os genótipos de HHV-8 são mantidos em descendentes que vivem fora de suas regiões geográficas de origem (Boshoff and 
Weiss, 2001; Fouchard et al., 2000; Zong et al., 1999; Whitby et al., 2004; Hayward and Zong, 2007; Kasolo et al., 2007).

A heterogênea composição étnica da população brasileira foi refletida na estreita associação das sequências de DNA de HHV-8 do nosso estudo com protótipos de diferentes origens etnogeográficas do mundo (Figura 16 e 17). Detectamos os quatro genótipos ou subtipos de HHV-8 A, B, C e F em ambos os grupos, grupo 1-SK e grupo $2-n S K$. O subtipo A e C é predominante no contexto do SK associado à aids e SK clássico na América do norte, em regiões da Europa e Ásia; o subtipo B tem sido descrito na África nos contextos do SK endêmico ou SK epidêmico. No Brasil, o subtipo F foi pela primeira vez descrito no atual estudo, em um indivíduo do grupo 1-SK e outro do grupo 2 -nSK. O subtipo F havia sido descrito previamente como exclusivo da África (Kajumbula et al., 2006).

No contexto da infecção pelo HIV, não detectamos nenhum subtipo E. O subtipo E foi pela primeira vez descrito por Biggar et al. (2000) ao avaliar as sequências da ORF K1 em CMSP de índios amazonenses, sem que fosse relatada a presença do SK. No entanto, no Peru, o subtipo E foi detectado no contexto SKaids (Cassar et al., 2010). Ainda outros estudos detectaram a transmissão familial do subtipo E pela saliva entre indios da amazonia brasiliera (Souza et al, 2007b; Borges et al., 2012).

A cor de pele e gênero foram características que não estiveram relacionados com algum genótipo de HHV-8 em nossa casuística.

Outra propriedade interessante que confirmamos nas sequências de aminoácidos (289 aa) do locus da ORF K1 foi o marcante predomínio de mutações não silenciosas (Figura 22) e destacamos quatro sítios positivamente selecionados com poder estatístico significativo $(p<0,005)$, tanto nas sequências de HHV-8 do grupo 1 e 2, igualmente visto nos protótipos já descritos previamente. Stebbing et al., 2003 demonstraram que a variabilidade de $\mathrm{K} 1$ é, pelo, menos em parte, dirigida pela resposta imune do hospedeiro, visto que identificaram a relação 
entre sítios de seleção positiva ao longo da ORF K1 de HHV-8 e epítopos de reconhecimento de Linfócitos $T$ citotóxicos. Esses, foram reconhecidos especialmente nas regiões K1/VR1 e K1/VR2.

Em geral, até $50 \%$ dos 289 aminoácidos na ORF K1 variam; cerca de 85\% das mudanças de aminoácidos produzem trocas cujas consequências indicam que não são produzidas aleatoriamente, mas que exista algum processo biológico de seleção envolvido. Tem-se proposto que o nível de substituição de aminoácidos na ORF K1 é aproximadamente equivalente ao observado nas regiões variáveis do gene ENV do HIV (Hayward, 1999; Hayward e Zong, 2007), embora não haja mecanismos conhecidos em herpesvirus comparáveis aos processos altamente mutagênicos da transcriptase reversa do HIV, que poderia ser capaz de gerar tal diversidade. No entanto, a seleção agindo durante a longa escala de tempo evolucionária pode ser capaz de gerar o padrão de variabilidade da ORF K1 (Hayward, 1999). O primeiro padrão de variabilidade é representada pelos genótipos ou subtipos diferentes entre os ramos A/C, B, D, E, F e Z, aparentemente refletindo a seleção evolucionária associada com a divergência migratória humana. Portanto, há um segundo padrão de variabilidade, os subgenótipos, os quais ocorrem entre (intertipos) e dentro (intratipos) dos subtipos, amplamente concentrado nos domínios VR1 e VR2 da ORF K1. Parte desse segundo padrão de variabilidade inclue diferenças que ocorrem dentro do grupamento C3 (observada na migração asiática mais recente) e A1 e A4 (associado à aids nos EUA). Entretanto, segundo Hayward e Zong (2007) esse tipo de variação subgenotípica pode ter surgido num prazo muito mais recente, que varia no máximo 400 anos a dentro dos últimos 20 anos de epidemia da aids.

Descrevemos pela primeira vez sequências de HHV-8 do locus K12 $(n=42)$ circulantes no Brasil nos grupos com e sem SK. A deleção de 4 nucleotídeos na sequência do locus K12 identificou a origem africana da sequência de HHV-8 do genótipo ou subtipo F de um paciente com SK desse estudo (SKL50) e 
igualmente identificado em um protótipo denominado SAN 1 (Whitby et al., 2004). A associação etnogeográfica também foi encontrada na análise das sequência de aminoácidos do gene da Kaposina (ORF K12) das sequências protótipos de HHV-8 da Grécia, África, EUA, Itália, Equador e sequências desse estudo, igualmente para o grupo 1 e 2 (Figura 24).

Observamos uma variabilidade inferior a $10 \%$ entre as sequências concentualmente traduzidas em aminoácidos (Figura 24) e a identidade entre as sequências desse estudo e as sequências prototípicas mostaram padrões genotípicos presentes no contexto SK-epidêmico, endêmico e clássico. Contudo, apenas um padrão foi específico das sequências desse estudo, em que o codon 59 (Figura 24) apresentou o aminoácido $E$ (ácido glutâmico) que predominou no grupo sem SK (6/9), formando um clado predominantemente K1 B e K12 B (Figura 17), sendo a maioria do grupo 2. As 9 sequências de aminoácidos de HHV-8 (Figura 24) apresentaram o mesmo códon na masma posição (referente ao ácido glutâmico) presente na Kaposina $A$, conforme sequência de aminoácido prototípica concentualmente traduzida, identificada como AAN64668 (Li et al., 2002). A Kaposina A tem sido descrita como uma proteína transmembrana e parece influenciar a proliferaçao celular e a tumorigênese na presença da proteína Tat do HIV, agindo como co-fator (Chen et al., 2009; Zhou et al., 2013). Observamos que a maioria dos indivíduos desse clado apresentou carga viral de HIV indetectável, de modo que a infecção pelo genótipo B do HHV-8 e a presumível falta do co-fator Tat do HIV poderiam relacionar-se à ausência de SK nessa condição, mas a falta de registro sobre a carga viral de HIV em alguns casos limitaram essa interpretação.

A análise filogenética das sequências de DNA de HHV-8 do locus K12 não foi capaz de distinguir entre o genótipo $A$ e $C$, de modo que 50 a $60 \%$ das sequências de DNA de HHV-8 aqui estudadas, do grupo 1 e 2, respectivamente, formaram um grupamento A/C. Segundo Hayward (1999), os genótipos A e C representam os mais novos ramos que surgiram a cerca de 35.000 anos atrás a partir do genótipo D, 
quando o homem moderno entrou na Europa e Ásia do Norte. Os genótipos A e C são muito mais similares entre si do que esses em relação ao genótipo $B$, que tem sido descrito como o mais primitivo (100.000 anos atrás). De fato, os genótipos A e C não puderam ser distinguíveis com grande suporte na filogenia por meio da análise do locus K12 (Figura 17), visto que não mostram mais que 2-5\% de variabilidade a nível de DNA comparado a 35\% - 40\% da ORF K1.

Podemos considerar que a variabilidade da ORF K12 é baixa e não é suficientemente capaz de distinguir o genótipo $A$ e $C$, que são genótipos muito próximos um do outro na escala evolutiva. A diferente pressão evolutiva exercida ao longo do genoma do HHV-8 pode explicar sua heterogeneidade, mais conservado ao centro (exemplo ORF K12, ORF 26, ORF 73) e mais variável próximo às extremidades (ORF K1 e ORF K15). A variabilidade da ORK K1 é fruto de grande pressão positiva, diferentemente do que ocorre com a ORF K12, conforme demonstrado na análise de seleção de sítios positivamente e negativamente selecionados (Figura 22). Por isso, o padrão genotípico A/C pode ser erroneamente interpretado como recombinante, baseando-se somente na análise do locus K12. Sequências de HHV-8 simultânemanente com K12 A/C e K1 A ou C encontradas aqui foram comumente encontradas em sequências de SK Clássico e epidêmico (Grécia, Itália, Estados Unidos) na era pré e pós aids, registrados entre 1975 a 2008 por Tornesello et al., 2010, e descritos em outros estudos (Zong et al., 2002, Poole et al., 1999).

Por outro lado, a presença de padrões do tipo K12 B e K1 A de HHV-8 foram também observadas em protótipos de HHV-8 da África, circulantes desde a era préaids (Hayward e Zong, 2007; Tornesello et al., 2010). Padrões semelhantes foram observados tanto no grupo 1 (K12 A/C e K1 B e K12 B e K1A) quanto no grupo 2 (K12 A/C e K1 B), sendo esses padrões previamente identificados como genomas recombinantes em estudos que avaliaram múltiplos genes (Zong et al., 2002; Whitby et al., 2004; Hayward e Zong, 2007; Tornesello el al., 2010), de modo que, mais uma 
vez, o fenômeno de recombinação não é descrito por esses autores como um evento novo, mas sim vírus com genomas recombinantes previamente circulantes.

\section{Análisamos SNPs em duas regiões codificadoras de microRNA (miR12-}

10, miR12-12) do locus K12, visto que trabalhos anteriores começaram a identificar regiões codificadoras de miRNA no locus de controle da latência (ORF K12) do HHV-8 e estudar a relação funcional desses microRNAs à tumorigenese (Grundhoff et al., 2006; Pfeffer et al., 2005; Marshall et al., 2010; Gottwein, 2012). Recentemente, foi demonstrado que SNPs em regiões codificadoras de miRNA do HHV-8 foram associados à diferentes níveis de expressão de microRNA, inclusive SNPs nessas regiões foram relacionados à mudanças no bioprocessamento enzimático do microRNA maduro, e consequentemente podendo interferir na expressão de genes virais (Han et al., 2013). Essas observações são importantes além do SK, visto que muitos canceres tem perfis de microRNA alterados (Calin et al., 2006). A proposta que esses dados trazem em pesquisar perfis de microRNA alterados na saliva pode se tornar uma ferramenta importante de diagnóstico na prática clínica.

No atual estudo, no trecho entre os nucleotídeos 117417 e 118055 do genoma de referência U75698 (locus K12) foram detectados 59 SNPs. Um total de 34\% (14/59) foram SNPs que ocorreram uma única vez, cuja probabilidade de estar relacionada a um erro da Taq polimerase não pode ser descartada. Não obstante, verificamos que a presença de SNPs em apenas uma amostra na nossa casuística, foi confirmada em algumas sequências protótipos do genBank, o que reduz a chance da presença desse SNP representar um erro aleatório da PCR.

Não houve diferença estatística que pudesse distinguir os grupos 1-SK e grupo 2-nSK quanto a presença/ausência de um dado SNP ao longo da ORF K12, principalmente devido ao número restrito de casos (Figura 23). Informações sobre esses SNPs aumentam de significado especialmente em regiões codificadoras de microRNA, que são, em geral, conservadas (Marshall et al., 2010). Encontramos 10\% 
(6/59) de sítios polimórficos no locus K12 em regiões codificadoras de miRNA. Desses, $70 \%$ foram presentes exclusivamente em casos de SK desse estudo e $80 \%$ de protótipos de SK.

Ainda estudos avaliaram a presença de SNPs no locus $\mathrm{K} 12$ e na região intergênica do genoma do HHV-8 e demonstraram que alguns SNPs têm potencial valor prognóstico ao risco de SK e outras doenças associados ao HHV-8, como a doença de Castleman e a Sindrome de Citocinas Inflamatórias (Marshall et al., 2010; Lu et al., 2010; Ray et al., 2012).

Marshall et al. (2010) analisaram os polimorfismos presentes em doze pequenas sequências codificadoras de microRNA do locus K12 e em região intergênica adjacente. Esses autores verificaram que alguns SNPs foram mais comuns em casos SK do que em controles, e apesar de não encontrarem diferença estatística significativa entre os grupos, a premissa do potencial valor prognóstico desses SNPs não pode ser descartada. Muitos estudos têm dado suporte experimental a essa premissa. Cai et al. (2005) observaram a produção de microRNAs em células latentemente infectadas e analisaram os potenciais alvos de RNA mensageiro dos miRNA virais. Muitos miRNA de HHV-8 estão envolvidos com alvos relacionados à proliferação celular, modulação imune, angiogenese e apoptose (Ramalingam et al., 2012). Atualmente, cada vez mais estudos têm buscado identificar os alvos celulares desses miRNAs e potenciais interferências no bioprocessamento do miRNA (Plaisance-Bonstaff et al., 2004; Gottwein et al., 2012; Grundhoff et al., 2011).

Potanto, supor que alterações no microRNA possam interferir no seu bioprocessamento, maturação e, consequentemente, no controle da expressão e silenciamento de genes, conduz ao interesse em avaliar os SNPs nas regiões codificadoras de miRNA em busca de um potencial valor clínico (Marshall et al., 2010; Ray et al., 2012; Han et al., 2013). Outrossim, uma vez que um microRNA maduro é gerado, ele pode ser incorporado ao complexo de silenciamento induzido 
por RNA. A complementaridade entre o microRNA e o RNAm leva a desestabilização do RNAm e/ou inibição da tradução da proteína.

No estudo atual detectamos um caso do grupo SK e três protótipos de SK endêmico em sítio polimórfico da região codificadora do miR12-12. SNPs em regiões codificadoras do miR12-10 foram presentes em sequências de HHV-8 de dois indivíduos com SK e dois sem SK, e ainda em sequências de 16 protótipos de SK (Uganda, Quênia, Itália, Grécia, Camarões). De todo o grupamento de microRNAs do HHV-8, os dois microRNA miR-12 e miR-10 foram os únicos não demonstrados no envolvimento da transição da fase de latência para a fase lítica do HHV-8 no contexto experimental demonstrado por Lei et al., 2010. Esses autores demonstraram que a deleção de todo o grupamento de microRNAs, exceto miR1212 e miR12-10, resulta no aumento na expressão de RTA e na produção de virions. Visto que o RTA é um ativador do ciclo lítico, foi demonstrado que os miRNAs de 1 a 9 e 11 parecem inibir a reativação lítica.

No entanto, em relação às funções relacionadas ao miR12-10, muitos estudos têm demonstrado seu papel na resistência à apoptose (por repressão de proteínas pró-apoptóticas ou por outros mecanismos anti-apoptóticos), aumento da reativação lítica, e redução da expressão de IL-8 (Ziegelbauer, et al., 2011; Abend et al., 2010).

Observamos que a presença de SNPs em miR12-10 e miR12-12 predominou no grupo 1-SK e nas sequências prototípicas nos contextos de SK epidêmico, endêmico e clássico, devido ao número restrito de casos, não houve diferença estatística (Tabela 21).

Outros estudos observaram a presença de mutação (exemplo, na posição 118037) que resultou no aumento da chance do vírus escapar dos linfócitos $T$ citotóxicos (Guihot et al., 2006; Wilkinson, et al., 2002. Esse sítio (posição 118037) foi conservado nas sequências desse estudo e protótipos. 
É importante que mais estudos possam abordar a análise de SNPs em sequências virais do locus K12 (e inclusive a região intergênica adjacente que não abordamos nesse estudo), a fim de esclarecer se esses SNPs interferem na geração de microRNA maduros e consequentemente, alterando o papel funcional desses miRNA e expressão de genes virais e celulares; e fundamentalmente trazendo o valor clínico a essas informações.

Nosso estudo teve algumas limitações. Não podemos ter certeza que os indivíduos do grupo 2 - nSK, que participaram do estudo na ocasião do uso de ART, não desenvolverão SK posteriormente, embora a maioria tenha sido infectada por HIV na mesma ocasião que o grupo 1-SK. E ainda, a infecção por HHV-8 só pode ser avaliada no grupo 2-nSK na ocasião do estudo (ano de 2007).

Outrossim, não fomos capazes de amplificar o DNA da maioria das amostras dos indivíduos com infecção por HIV sem SK do locus K1 e K12 para sequenciamento, mesmo diante de carga viral detectável, porém a proporção mínima de 1:1 para a comparação estatística dos grupos foi obtida. Ainda, em relação a análise de SNPs no locus $\mathrm{K} 12$, julgamos que essa foi restrita devido a presença de sequências com comprimento limitado em tamanho (variando em torno de 400 a 700 nucleotídeos), consequentemente reduzindo o poder estatístico da análise.

Contudo, a limitação se estende a maioria dos trabalhos publicados em relação à obtenção de DNA de HHV-8 para genotipagem. E essa limitação vem sendo superada à medida que as variantes de HHV-8 são reconhecidas e os estudos possam alcançar maior abrangência geográfica. 
- A presença de SK ou estadio clínico de SK não parecem estar relacionados a um determinado genótipo de HHV-8;

- O subgenótipo B1 foi significativamente predominante entre os indivíduos infectados por HIV sem registro de piora clínica de SK, e pode ser relacionado ao melhor prognóstico do SK;

- Foram detectados alguns recombinantes de HHV-8 no grupo sem SK na análise do locus $\mathrm{K} 1$, e esses parecem não ser originados de eventos novos, mas sim, recombinantes circulantes já extensivamente descritos.

- A conservação do vírus HHV-8 pode ser demonstrada pela alta similaridade entre sequências de DNA de HHV-8 de amostras coletadas em tempos diferentes.

- Embora não houvesse diferença entre presença/ausência de SNPs em sequências da ORF K12 de HHV-8 em indivíduos dos grupos com e sem SK, alguns sítios polimórficos em regiões codificadoras de microRNA foram particularmente encontrados em sequências de DNA de HHV-8 de indivíduos com SK do estudo atual e protótipos do contexto SK clássico, endêmico e epidêmico. 
- Os primers dirigidos às regiões K1/VR1, K1/VR2 e associados ao uso dos primers de $\mathrm{K} 1$ completo foram úteis de forma complementar para detectar os genótipos e um maior perfil de subgenótipos de HHV-8 em indivíduos infectados por HIV dos grupos com e sem SK em relação à estudos anteriores no Brasil. 
Abend JR, Ramalingam D, Kieffer-Kwon P, Uldrick TS, Yarchoan R, Ziegelbauer JM. Kaposi's sarcoma-associated herpesvirus microRNAs target IRAK1 and MYD88, two components of the toll-like receptor/interleukin-1R signaling cascade, to reduce inflammatory-cytokine expression. J Virol. 2012;86(21):11663-74.

Ablashi DV, Chatlynne LG, Whitman JE, Cesarman E. Spectrum of Kaposi's sarcoma-associated herpesvirus, or human herpesvirus 8, diseases. Clin Microbiol Rev. 2002;15(3):439-64.

Aguilar B, Choi I, Choi D, Chung HK, Lee S, Yoo J, et al. Lymphatic reprogramming by Kaposi sarcoma herpes virus promotes the oncogenic activity of the virusencoded G-protein-coupled receptor. Cancer Res. 2012;72(22):5833-42.

Alagiozoglou L, Sitas F, Morris L. Phylogenetic analysis of human herpesvirus-8 in South Africa and identification of a novel subgroup. J Gen Virol. 2000;81(Pt 8):2029-38.

Alcami A. Viral mimicry of cytokines, chemokines and their receptors. Nat Rev Immunol. 2003;3(1):36-50.

Andreoni M, El-Sawaf G, Rezza G, Ensoli B, Nicastri E, Ventura L, et al. High seroprevalence of antibodies to Human Herpesvirus 8 in Egyptian children: evidence of non sexual transmission. J Natl Cancer Inst. 1999; 91: 465-9.

Aoki Y, Tosato G. Interactions between HIV-1 Tat and KSHV. Curr Top Microbiol Immunol. 2007;312:309-26.

Appay V, Almeida JR, Sauce D, Autran B, Papagno L. Accelerated immune senescence and HIV-1 infection. Exp Gerontol. 2007;42(5):432-7.

Armstrong AW, Lam KH, Chase EP. Epidemiology of classic and AIDS-related Kaposi's sarcoma in the USA: incidence, survival, and geographical distribution from 1975 to 2005. Epidemiol Infect. 2013;141(1):200-6.

Arvanitakis L, Geras-Raaka E, Varma A, Gershengorn MC, Cesarman E. Human herpesvirus KSHV encodes a constitutively active G-protein-coupled receptor linked to cell proliferation. Nature. 1997;385(6614):347-50.

Bais C, Santomasso B, Coso O, Arvanitakis L, Raaka EG, Gutkind JS, et al. Gprotein-coupled receptor of Kaposi's sarcoma-associated herpesvirus is a viral oncogene and angiogenesis activator. Nature. 1998;391(6662):86-9.

Bais C, Van Geelen A, Eroles P, Mutlu A, Chiozzini C, Dias S, et al. Kaposi's sarcoma associated herpesvirus $G$ protein-coupled receptor immortalizes human endothelial cells by activation of the VEGF receptor-2/ KDR. Cancer Cell. 2003;3(2):131-43.

Ballestas ME, Chatis PA, Kaye KM. Efficient persistence of extrachromosomal KSHV DNA mediated by latency-associated nuclear antigen. Science. 1999;284(5414):641-4. 
Ballestas ME, Kaye KM. Kaposi's sarcoma-associated herpesvirus latencyassociated nuclear antigen 1 mediates episome persistence through cis-acting terminal repeat (TR) sequence and specifically binds TR DNA. J Virol. $2001 ; 75(7): 3250-8$.

Barbera AJ, Chodaparambil JV, Kelley-Clarke B, Joukov V, Walter JC, Luger K, et al. The nucleosomal surface as a docking station for Kaposi's sarcoma herpesvirus LANA. Science. 2006;311(5762):856-61.

Beral V, Peterman TA, Berkelman RL, Jaffe HW. Kaposi's sarcoma among persons with AIDS: a sexually transmitted infection? Lancet. 1990;335(8682):123-8.

Bernstein WB, Little RF, Wilson WH, Uarchoan R. Acquired immunodeficiency syndrome-related malignancies in era of highly active antiretroviral therapy. Int $\mathrm{J}$ Hematol. 2006; 84:3-11.

Beyari MM, Hodgson TA, Cook RD, Kondowe W, Molyneux EM, Scully CM, et al. Multiple human herpesvirus-8 infection. J Infect Dis. 2003;188(5):678-89.

Bhagwat GP, Naik KG, Sachdeva R, Bhushan V. Disseminated lymphadenopathic Kaposi's sarcoma in Zambian children. Med J Zambia. 1980;14(4):61-3.

Biggar RJ, Horm J, Goedert JJ, Melbye M. Cancer in a group at risk of acquired immunodeficiency syndrome (AIDS) through 1984. Am J Epidemiol. 1987;126(4):578-86.

Biggar RJ, Rosenberg PS, Cote T. Kaposi's sarcoma and non-Hodgkins's lymphoma following the diagnosis of aids. Mustistate aids/Cancer Match Study Group. Int J Cancer. 1996; 68: 754-8.

Biggar RJ, Whitby D, Marshall V, Linhares AC, Black F. Human herpesvirus 8 in Brazilian Amerindians: A hyperendemic population with a new subtype. J Infect Dis. 2000;181(5):1562-8.

Biggar RJ, Kirby KA, Atkinson J, McNeel TS, Engels E, Group ACMS. Cancer risk in elderly persons with HIV/AIDS. J Acquir Immune Defic Syndr. 2004;36(3):861-8.

Biggar RJ, Chaturvedi AK, Goedert JJ, Engels EA; Study HACM. Aids-related cancer and severity of immunosuppression in persons with aids. J Natl Cancer Inst. 2007; 99(12):962-72.

Blackbourn DJ, Lennette ET, Ambroziak J, Mourich DV, Levy JA. Human herpesvirus 8 detection in nasal secretions and saliva. J Infect Dis. 1998;177(1):213-6.

Boralevi F, Masquelier B, Denayrolles M, Dupon M, Pellegrin JL, Ragnaud JM, et al. Study of human herpesvirus 8 (HHV-8) variants from Kaposi's sarcoma in France: Is HHV-8 subtype a responsible for more aggressive tumors? J of Infect Dis. 1998;178(5):1546-7. 
Borges JD, Souza VA, Giambartolomei C, Dudbridge F, Freire WS, Gregório SA, et al. Transmission of human herpesvirus type 8 infection within families in american indigenous populations from the Brazilian Amazon. J Infect Dis. 2012;205(12):1869-76.

Boshoff C, Talbot S, Kennedy M, O'Leary J, Schulz T, Chang Y. HHV8 and skin cancers in immunosuppressed patients. Lancet. 1996;347(8997):338-9.

Boshoff C, Whitby D, Hatziionno I, Fisher C, Wan der Walt J, Weiss R, et al. Kaposi's-Sarcoma-associated herpesvirus in HIV-negative Kaposi's Sarcoma. Lancet. 1995;345:1043-4.

Boshoff C, Weiss RA. Epidemiology and pathogenesis of Kaposi sarcoma-associated herpesvirus. Philos Trans R Soc Lond B. 2001;356:517-34.

Brasil. Ministério da Saúde, Secretaria de Vigilância em Saúde - Boletim Epidemiológico - Ano XII - dezembro 1999 a junho 2000 [citado 12 jul 2013]. Disponível em: www.aids.gov.br/ 2000.

Brasil. Ministério da Saúde, Secretaria de Vigilância em Saúde - Boletim Epidemiológico DST/aids/Tabnet_2005 [citado 12 jul 2013]. Disponível em: www.aids.gov.br/2005.

Brasil. Minsitério da saúde, Secretaria da Vigilancia em Saúde - Boletim Informativo DST/AIDS [citado 12 jul 2013]. Disponível em: www.aids.gov.br/_publicacao/2012/boletim-epidemiologico-aids-e-dst-2012_2012.

Brinkmann MM, Pietrek M, Dittrich-Breiholz O, Kracht M, Schulz TF. Modulation of host gene expression by the $\mathrm{K} 15$ protein of Kaposi's sarcoma-associated herpesvirus. J Virol. 2007;81(1):42-58.

Brown EE, Fallin D, Ruczinski I, Hutchinson A, Staats B, Vitale F, et al. Associations of classic Kaposi sarcoma with common variants in genes that modulate host immunity. Cancer Epidemiol Biomarkers Prev. 2006;15(5):926-34.

Buonaguro FM, Tomesello ML, Buonaguro L, Satriano RA, Ruocco E, Castello G, et al. Kaposi's sarcoma: aetiopathogenesis, histology and clinical features. J Eur Acad Dermatol Venereol. 2003;17(2):138-54.

Cai X, Lu S, Zhang Z, Gonzalez CM, Damania B, Cullen BR. Kaposi's sarcomaassociated herpesvirus expresses an array of viral microRNAs in latently infected cells. Proc Natl Acad Sci U S A. 2005;102(15):5570-5.

Calin, G. A., and C. M. Croce. MicroRNA signatures in human cancers. Nat Rev Cancer. 2006; 6:857-866.

Cannon JS, Ciufo D, Hawkins AL, Griffin CA, Borowitz MJ, Hayward GS, et al. A new primary effusion lymphoma-derived cell line yields a highly infectious Kaposi's sarcoma herpesvirus-containing supernatant. J Virol. 2000;74(21):10187-93. 
Cannon MJ, Laney AS, Pellett PE. Human herpesvirus 8: current issues. Clin Infect Dis. 2003;37(1):82-7.

Cannon MJ, Operskalski EA, Mosley JW, Radford K, Dollard SC. Lack of evidence for human herpesvirus-8 transmission via blood transfusion in a historical US cohort. J Infect Dis. 2009; 199(11): 1592-8.

Casper C, Redman M, Huang ML, Pauk J, Lampinem TM, Hawes SE et al. HIV infection and human herpesvirus 8 oral shedding among men who have sex with men. J acquir Immune Defic Syndr. 2004;35:233-38.

Casper C, Krantz E, Selke S, Kuntz SR, Wang J, Huang ML, et al. Frequent and asymptomatic oropharyngeal shedding of human herpesvirus 8 among immunocompetent men. J Infect Dis. 2007;195(1):30-6.

Cassar O, Afonso PV, Bassot S, Plancoulaine S, Duprez R, Capuano C, et al. Novel human herpesvirus 8 subtype D strains in Vanuatu, Melanesia. Emerg Infect Dis. 2007;13(11):1745-8.

Cassar O, Blondot ML, Mohanna S, Jouvion G, Bravo F, Maco V, et al. Human herpesvirus 8 genotype $E$ in patients with Kaposi sarcoma, Peru. Emerg Infect Dis. 2010;16(9):1459-62.

Caterino-de-Araujo A. Human herpesvirus 8 group $B$ and $C$ variants circulating in São Paulo, Brazil. J Infect Dis. 1998;177(4):1136-7.

Caterino-de-Araujo A, Calabrò ML, de los Santos-Fortuna E, Suleiman J, ChiecoBianchi L. Searching for human herpesvirus 8 antibodies in serum samples from patients infected with human immunodeficiency virus type 1 and blood donors from São Paulo, Brazil. J Infect Dis. 1999;179(6):1591-2.

Caterino-de-Araujo A, de los Santos-Fortuna E, Carbone PH, Cibella SE, Moreira AA. Human herpesvirus-8 (HHV-8) antibodies in women from São Paulo, Brazil. Association with behavioral factors and Kaposi's sarcoma. Braz $\mathrm{J}$ Infect Dis. 2003;7(6):395-401.

Centers for Disease Control (CDC). 1993. Revised classification system for HIV infection and expanded surveillance case definition for aids among adolescents and adults. Morbid Mortal Week Resp 1992; 41: 1-19.

Chaabna Mokrane K, Bray F, Wabinga HR, Chokunonga E, Borok M, Vanhems $P$, et al. Kaposi sarcoma trends in Uganda and Zimbabwe: A sustained decline in incidence? Int J Cancer. 2013; 133(5):1197-203.

Chang Y, Cesarman E, Pessin MS, Lee F, Culpepper J, Knowles DM, et al. Identification of herpesvirus-like DNA sequences in AIDS-associated Kaposi's sarcoma. Science. 1994;266(5192):1865-9. 
Chang $\mathrm{Y}$, Ziegler J, Wabinga $\mathrm{H}$, Katangole-Mbidde $\mathrm{E}$, Boshoff $\mathrm{C}$, Schulz $\mathrm{T}$, et al. Kaposi's sarcoma-associated herpesvirus and Kaposi's sarcoma in Africa. Uganda Kaposi's Sarcoma Study Group. Arch Intern Med. 1996;156(2):202-4.

Chen X, Cheng L, Jia X, Zeng Y, Yao S, Lv Z, et al.Human immunodeficiency virus type 1 Tat accelerates Kaposi sarcoma-associated herpesvirus Kaposin A-mediated tumorigenesis of transformed fibroblasts in vitro as well as in nude and immunocompetent mice. Neoplasia. 2009;11(12):1272-84.

Chokunonga E, Borok M, Chirenje Z, Nyakabau A, Parkin D. Trends in the incidence of cancer in the black population of harare, zimbabwe 1991-2010. Int J Cancer. 2013; 133(3):721-9.

Chokunonga E, Levy LM, Bassett MT, Mauchaza BG, Thomas DB, Parkin DM. Cancer incidence in the African population of Harare, Zimbabwe: second results from the cancer registry 1993-1995. Int J Cancer. 2000;85(1):54-9.

Chung YH, Means RE, Choi JK, Lee BS, Jung JU. Kaposi's sarcoma-associated herpesvirus OX2 glycoprotein activates myeloid-lineage cells to induce inflammatory cytokine production. J Virol. 2002;76(10):4688-98.

Cook PM, Whitby D, Calabro ML, Luppi M, Kakoola DN, Hjalgrim H, et al. Variability and evolution of Kaposi's sarcoma-associated herpesvirus in Europe and Africa. International Collaborative Group. AIDS. 1999;13(10):1165-76.

Cotter MA, Robertson ES. The latency-associated nuclear antigen tethers the Kaposi's sarcoma-associated herpesvirus genome to host chromosomes in body cavity-based lymphoma cells. Virology. 1999;264(2):254-64.

Cotter MA, Subramanian C, Robertson ES. The Kaposi's sarcoma-associated herpesvirus latency-associated nuclear antigen binds to specific sequences at the left end of the viral genome through its carboxy-terminus. Virology. 2001;291(2):241-59.

Dal Maso L, Polesel J, Serraino D, Lise M, Piselli P, Falcini F, et al. Pattern of cancer risk in persons with AIDS in Italy in the HAART era. Br J Cancer. 2009;100(5):840-7.

Damania B. Oncogenic gamma-herpesvirus: comparison of viral proteins involved in tumorigenesis. Nat Rev Microbiol. 2004;2(8):656-68.

Darwich L, Videla S, Cañadas MP, Piñol M, García-Cuyàs F, Vela $S$, et al. Distribution of Human Papillomavirus Genotypes in Anal Cytological and Histological Specimens from HIV-Infected Men Who Have Sex with Men and Men Who Have Sex with Women. Dis Colon Rectum. 2013;56(9):1043-52.

de França TR, de Araújo RA, Ribeiro CM, Leao JC. Salivary shedding of HHV-8 in people infected or not by human immunodeficiency virus 1. J Oral Pathol Med. 2011;40(1):97-102. 
Dedicoat M, Newton R, Alkharsah KR, Sheldon J, Szabados I, Ndlovu B, et al. Mother-to-child transmission of human herpesvirus-8 in South Africa. J Infect Dis. 2004;190(6):1068-75.

Del Mistro A, Baboci L, Frayle-Salamanca H, Trevisan R, Bergamo E, Lignitto L, et al. Oral Human Papillomavirus and Human Herpesvirus-8 Infections Among Human Immunodeficiency Virus Type 1-Infected Men and Women in Italy. Sex Transm Dis. 2012;39(11):894-8.

Derhovanessian E, Solana R, Larbi A, Pawelec G. Immunity, ageing and cancer. Immun Ageing. 2008;5:11.

Dezube BJ. Clinical presentation and natural history of AIDS-related Kaposi's sarcoma. Hematology-Oncology Clinics of North America. 1996;10(5):1023-9.

Di Alberti L, Ngui SL, Porter SR, Speight PM, Scully CM, Zakrewska JM, et al. Presence of human herpesvirus 8 variants in the oral tissues of human immunodeficiency virus-infected persons. J Infect Dis. 1997;175(3):703-7.

Djerbi M, Screpanti V, Catrina Al, Bogen B, Biberfeld P, Grandien A. The inhibitor of death receptor signaling, FLICE-inhibitory protein defines a new class of tumor progression factors. J Exp Med. 1999;190(7):1025-32.

Dollard SC, Nelson KE, Ness PM, Stambolis V, Kuehnert MJ, Pellett PE, et al. Possible transmission of human herpesvirus- 8 by blood transfusion in a historical United States cohort. Transfusion. 2005;45(4):500-3.

Dorak MT, Yee LJ, Tang J, Shao W, Lobashevsky ES, Jacobson LP, et al. HLA-B, DRB1/3/4/5, and -DQB1 gene polymorphisms in human immunodeficiency virusrelated Kaposi's sarcoma. J Med Virol. 2005;76(3):302-10.

Dupin N, Grandadam M, Calvez V, Gorin I, Aubin JT, Havard S, et al. Herpesviruslike DNA sequences in patients with Mediterranean Kaposi's sarcoma. Lancet. 1995;345(8952):761-2.

Dupin N, Fisher C, Kellam P, Ariad S, Tulliez M, Franck N, et al. Distribution of human herpesvirus-8 latently infected cells in Kaposi's sarcoma, multicentric Castleman's disease, and primary effusion lymphoma. Proc Natl Acad Sci U S A. 1999a;96(8):4546-51.

Dupin N, Rubin De Cervens V, Gorin I, Calvez V, Pessis E, Grandadam M, et al. The influence of highly active antiretroviral therapy on AIDS-associated Kaposi's sarcoma. Br J Dermatol. 1999b;140(5):875-81.

Duprez R, Cassar O, Hbid O, Rougier Y, Morisse L, Bassot S, et al. Cutaneous disseminated endemic Kaposi's sarcoma in a Polynesian man infected with a new divergent human herpesvirus 8 subtype D. J Clin Virol. 2006a;37(3):222-6. 
Duprez R, Hbid O, Afonso P, Quach H, Belloul L, Fajali N, et al. Molecular epidemiology of the HHV-8 K1 gene from Moroccan patients with Kaposi's sarcoma. Virology. 2006b;353(1):121-32.

Duus KM, Lentchitsky V, Wagenaar T, Grose C, Webster-Cyriaque J. Wild-type Kaposi's sarcoma-associated herpesvirus isolated from the oropharynx of immunecompetent individuals has tropism for cultured oral epithelial cells. J Virol. 2004;78(8):4074-84.

Edelman DC. Human herpesvirus 8--a novel human pathogen. Virol J. 2005;2:78.

Endo T, Miura T, Koibuchi T, Nakamura H, Takahashi T, Odawara T, et al. Molecular analysis of human herpesvirus 8 by using single nucleotide polymorphisms in open reading frame 26. J Clin Microbiol. 2003;41(6):2492-7.

Ensoli B, Barillari G, Salahuddin SZ, Gallo RC, Wong-Staal F. Tat protein of HIV-1 stimulates growth of cells derived from Kaposi's sarcoma lesions of AIDS patients. Nature. 1990;345(6270):84-6.

Fairall LR, Bachmann MO, Louwagie GM, van Vuuren C, Chikobvu P, Steyn D, et al. Effectiveness of antiretroviral treatment in a South African program: a cohort study. Arch Intern Med. 2008;168(1):86-93.

Faridi R, Zahra A, Khan K, Idrees M. Oncogenic potential of Human Papillomavirus (HPV) and its relation with cervical cancer. Virol J. 2011;8:269.

Fink MC, de Oliveira AC, Romano CM, Vidal JE, Urbano PR, Tateno AF, et al. Molecular characterization of human polyomavirus JC in Brazilian AIDS patients with and without progressive multifocal leukoencephalopathy. J Clin Virol. 2010;48:6-10.

Fouchard N, Lacoste V, Couppie P, Develoux M, Mauclere P, Michel P, et al. Detection and genetic polymorphism of human herpes virus type 8 in endemic or epidemic Kaposi's sarcoma from West and Central Africa, and South America. Int J Cancer. 2000;85(2):166-70.

Franceschi S, Lise M, Clifford GM, Rickenbach M, Levi F, Maspoli M, et al. Changing patterns of cancer incidence in the early- and late-HAART periods: the Swiss HIV Cohort Study. Br J Cancer. 2010;103(3):416-22.

Freitas RB, Freitas MR, Linhares AC. Prevalence of human herpesvirus 8 antibodies in the population of Belém, Pará, Brazil. Rev Inst Med Trop Sao Paulo. 2002;44(6):309-13.

Friborg J, Kong W, Hottiger MO, Nabel GJ. p53 inhibition by the LANA protein of KSHV protects against cell death. Nature. 1999;402(6764):889-94. 
Friedman SL, Wright TL, Altman DF. Gastrointestinal Kaposi's sarcoma in patients with acquired immunodeficiency syndrome. Endoscopic and autopsy findings. Gastroenterology. 1985;89(1):102-8.

Friedman-Kien AE. Disseminated Kaposi's sarcoma syndrome in young homosexual men. J Am Acad Dermatol. 1981;5(4):468-71.

Gallafent JH, Buskin SE, De Turk PB, Aboulafia DM. Profile of patients with Kaposi's sarcoma in Theera of highly active antiretroviral therapy. J Clin Oncol. 2005; 23:1253-60.

Gallo RC. The enigmas of Kaposi's sarcoma. Science. 1998;282(5395):1837-9.

Gandhi M, Koelle DM, Ameli N, Bacchetti P, Greenspan JS, Navazesh M, et al. Prevalence of human herpesvirus-8 salivary shedding in HIV increases with CD4 count. J Dent Res. 2004;83(8):639-43.

Ganem D. KSHV and the pathogenesis of Kaposi sarcoma: listening to human biology and medicine. J Clin Invest. 2010;120(4):939-49.

Gao SJ, Kingsley L, Li M, Zheng W, Parravicini C, Ziegler J, et al. KSHV antibodies among Americans, Italians and Ugandans with and without Kaposi's sarcoma. Nat Med. 1996;2(8):925-8.

Garber AC, Hu J, Renne R. Latency-associated nuclear antigen (LANA) cooperatively binds to two sites within the terminal repeat, and both sites contribute to the ability of LANA to suppress transcription and to facilitate DNA replication. J Biol Chem. 2002;277(30):27401-11.

Garber AC, Shu MA, Hu J, Renne R. DNA binding and modulation of gene expression by the latency-associated nuclear antigen of Kaposi's sarcomaassociated herpesvirus. J Virol. 2001;75(17):7882-92.

Gayà A, Esteve A, Casabona J, McCarthy JJ, Martorell J, Schulz TF, et al. Amino acid residue at position 13 in HLA-DR beta chain plays a critical role in the development of Kaposi's sarcoma in AIDS patients. AIDS. 2004;18(2):199-204.

Giraldo G, Beth E, Haguenau F. Herpes-type virus particles in tissue culture of Kaposi's sarcoma from different geographic regions. J Natl Cancer Inst. 1972;49(6):1509-26.

Giraldo G, Beth E, Huang ES. Kaposi's sarcoma and its relationship to cytomegalovirus (CMNV). III. CMV DNA and CMV early antigens in Kaposi's sarcoma. Int J Cancer. 1980;26(1):23-9.

Gooding LR. Virus proteins that counteract host immune defenses. Cell. 1992;71(1):5-7. 
Gottlieb GJ, Ragaz A, Vogel JV, Friedman-Kien A, Rywlin AM, Weiner EA, et al. A preliminary communication on extensively disseminated Kaposi's sarcoma in young homosexual men. Am J Dermatopathol. 1981;3(2):111-4.

Gottwein E. Kaposi's Sarcoma-Associated Herpesvirus microRNAs. Front Microbiol. 2012;3:165

Gouy M, Guindon S, Gascuel O. SeaView version 4: A multiplatform graphical user interface for sequence alignment and phylogenetic tree building. Mol Biol Evol. 2010;27(2):221-4.

Grulich AE, van Leeuwen MT, Falster MO, Vajdic CM. Incidence of cancers in people with HIV/AIDS compared with immunosuppressed transplant recipients: a metaanalysis. Lancet. 2007;370(9581):59-67.

Grundhoff A, Ganem D. Inefficient establishment of KSHV latency suggests an additional role for continued lytic replication in Kaposi sarcoma pathogenesis. J Clin Invest. 2004;113(1):124-36.

Grundhoff A, Sullivan CS, Ganem D. A combined computational and microarraybased approach identifies novel microRNAs encoded by human gammaherpesviruses. RNA. 2006;12(5):733-50.

Grundhoff A, Sullivan CS. Virus-encoded microRNAs. Virology. 2011;411(2):325-43.

Guihot A, Dupin N, Marcelin AG, Gorin I, Bedin AS, Bossi P, et al. Low T cell responses to human herpesvirus 8 in patients with AIDS-related and classic Kaposi sarcoma. J Infect Dis. 2006;194(8):1078-88.

Guindon S, Gascuel O. A simple, fast, and accurate algorithm to estimate large phylogenies by maximum likelihood. Syst Biol. 2003;52(5):696-704.

Guttman-Yassky E, Bar-Chana M, Yukelson A, Linn S, Friedman-Birnbaum R, Bergman R, et al. Epidemiology of classic Kaposi's sarcoma in the Israeli Jewish population between 1960 and 1998. Br J Cancer. 2003;89(9):1657-60.

Guttman-Yassky E, Cohen A, Kra-Oz Z, Friedman-Birnbaum R, Sprecher E, Zaltzman N, et al. Familial clustering of classic Kaposi sarcoma. J Infect Dis. 2004;189(11):2023-6.

Han SJ, Marshall V, Barsov E, Quiñones O, Ray A, Labo N, et al. KSHV encoded microRNA Single Nucleotide Polymorphisms Identified in Clinical Samples can affect microRNA Processing, Level of Expression and Silencing Activity. J Virol. 2013. Accepts published online ahead of print on 4 september 2013. doi:10.1128/JVI.01202-13. http://jvi.asm.org/content/early/2013/08/29/JVI.0120213.full.pdf. 
Hayward GS. KSHV strains: the origins and global spread of the virus. Sem Cancer Biol. 1999;9(3):187-99.

Hayward GS, Zong JC. Modern evolutionary history of the human KSHV genome. Curr Top Microbiol Immunol. 2007;312:1-42.

Hladik W, Dollard SC, Mermin J, Fowlkes AL, Downing R, Amin MM, et al. Transmission of human herpesvirus 8 by blood transfusion. $\mathrm{N}$ Engl $\mathrm{J}$ Med. 2006;355(13):1331-8.

Hladik W, Pellett PE, Hancock J, Downing R, Gao H, Packel L, et al. Association between transfusion with human herpesvirus 8 antibody-positive blood and subsequent mortality. J Infect Dis. 2012;206(10):1497-503.

Honda K, Yanai H, Negishi H, Asagiri M, Sato M, Mizutani T, et al. IRF-7 is the master regulator of type-I interferon-dependent immune responses. Nature. 2005;434(7034):772-7.

Hong YK, Foreman K, Shin JW, Hirakawa S, Curry CL, Sage DR, et al. Lymphatic reprogramming of blood vascular endothelium by Kaposi sarcoma-associated herpesvirus. Nat Genet. 2004;36(7):683-5.

Huang L, Schnapp LM, Gruden JF, Hopewell PC, Stansell JD. Presentation of AIDSrelated pulmonary Kaposi's sarcoma diagnosed by bronchoscopy. Am J Respir Crit Care Med. 1996;153(4 Pt 1):1385-90.

Hymes KB, Cheung T, Greene JB, Prose NS, Marcus A, Ballard H, et al. Kaposi's sarcoma in homosexual men-a report of eight cases. Lancet. 1981;2(8247):598-600.

loachim HL, Adsay V, Giancotti FR, Dorsett B, Melamed J. Kaposi's sarcoma of internal organs. A multiparameter study of 86 cases. Cancer. 1995;75(6):1376-85.

Iscovich J, Boffetta P, Franceschi S, Azizi E, Sarid R. Classic Kaposi sarcoma Epidemiology and risk factors. Cancer. 2000;88(3):500-17.

Ishak MDG, Martins RN, Machado PRL, de Souza LLB, Machado LFA, Azevedo VN, et al. High diversity of HHV-8 molecular subtypes in the Amazon region of Brazil: Evidence of an ancient human infection. J Med Virol. 2007;79(10):1537-44.

Jalilvand S, Tornesello ML, Buonaguro FM, Buonaguro L, Naraghi ZS, Shoja Z, et al. Molecular epidemiology of human herpesvirus 8 variants in Kaposi's sarcoma from Iranian patients. Virus Res. 2012;163(2):644-9.

Jenner RG, Albà MM, Boshoff C, Kellam P. Kaposi's sarcoma-associated herpesvirus latent and lytic gene expression as revealed by DNA arrays. J Virol. 2001;75(2):891-902. 
Jenner RG, Boshoff C. The molecular pathology of Kaposi sarcoma-associated herpesvirus. Biochim Biophys Acta. 2002 (1); 1602:1-22.

Jussila L, Valtola R, Partanen TA, Salven P, Heikkilä $P$, Matikainen MT, et al. Lymphatic endothelium and Kaposi's sarcoma spindle cells detected by antibodies against the vascular endothelial growth factor receptor-3. Cancer Res. 1998;58(8):1599-604.

Kadyrova E, Lacoste V, Duprez R, Pozharissky K, Molochkov V, Huerre M, et al. Molecular epidemiology of Kaposi's sarcoma-associated herpesvirus/human herpesvirus 8 strains from Russian patients with classic, posttransplant, and AIDSassociated Kaposi's sarcoma. J Med Virol. 2003;71(4):548-56.

Kajumbula H, Wallace RG, Zong JC, Hokello J, Sussman N, Simms S, et al. Ugandan Kaposi's sarcoma-associated herpesvirus phylogeny: evidence for crossethnic transmission of viral subtypes. Intervirology. 2006;49(3):133-43.

Kakoola DN, Sheldon J, Byabazaire N, Bowden RJ, Katongole-Mbidde E, Schulz TF, et al. Recombination in human herpesvirus- 8 strains from Uganda and evolution of the K15 gene. J Gen Virol. 2001;82:2393-404.

Kasolo FC, Monze M, Obel N, Anderson RA, French C, Gompels UA. Sequence analyses of human herpesvirus-8 strains from both African human immunodeficiency virus-negative and -positive childhood endemic Kaposi's sarcoma show a close relationship with strains identified in febrile children and high variation in the K1 glycoprotein. J Gen Virol. 1998;79 ( Pt 12):3055-65.

Kasolo FC, Spinks J, Bima H, Bates M, Gompels UA. Diverse genotypes of Kaposi's sarcoma associated herpesvirus (KSHV) identified in infant blood infections in African childhood-KS and HIV/AIDS endemic region. J Med Virol. 2007;79(10):1555-61.

Kazanji M, Dussart P, Duprez R, Tortevoye P, Pouliquen JF, Vandekerkhove J, et al. Serological and molecular evidence that human herpesvirus 8 is endemic among Amerindians in French Guiana. J Infect Dis. 2005;192(9):1525-9.

Kedes DH, Operskalski E, Busch M, Kohn R, Flood J, Ganem D. The seroepidemiology of human herpesvirus 8 (Kaposi's sarcoma-associated herpesvirus): distribution of infection in KS risk groups and evidence for sexual transmission. Nat Med. 1996;2(8):918-24.

Keller R, Zago A, Viana MC, Bourboulia D, Desgranges C, Casseb J, et al. HHV-8 infection in patients with AIDS-related Kaposi's sarcoma in Brazil. Brazilian J Medi Biol Res. 2001;34(7):879-86.

Kestens L, Melbye M, Biggar RJ, Stevens WJ, Piot P, De Muynck A, et al. Endemic African Kaposi's sarcoma is not associated with immunodeficiency. Int $\mathrm{J}$ Cancer. 1985;36(1):49-54. 
Kirchhoff S, Sebens T, Baumann S, Krueger A, Zawatzky R, Li-Weber M, et al. Viral IFN-regulatory factors inhibit activation-induced cell death via two positive regulatory IFN-regulatory factor 1-dependent domains in the CD95 ligand promoter. J Immunol. 2002;168(3):1226-34.

Koelle DM, Huang ML, Chandran B, Vieira J, Piepkorn M, Corey L. Frequent detection of Kaposi's sarcoma-associated herpesvirus (human herpesvirus 8) DNA in saliva of human immunodeficiency virus-infected men: clinical and immunologic correlates. J Infect Dis. 1997;176(1):94-102.

Konrad A, Wies E, Thurau M, Marquardt G, Naschberger E, Hentschel S, et al. A systems biology approach to identify the combination effects of human herpesvirus 8 genes on NF-kappaB activation. J Virol. 2009;83(6):2563-74.

Kouri V, Marini A, Doroudi R, Nambiar S, Rodriguez ME, Capo V, et al. Molecular epidemiology of Kaposi's sarcoma herpesvirus (KSHV) in Cuban and German patients with Kaposi's sarcoma (KS) and asymptomatic sexual contacts. Virology. 2005; 337(2):297-303.

Kouri V, Martínez PA, Blanco O, Capó V, Rodríguez ME, Dovigny Mdel C, et al.. Simultaneous quantification of human herpesvirus 8 DNA by real time PCR in different tissues of HIV infected cuban patients with Kaposi's sarcoma. Herpesviridae. 2010;1:3.

Kouri V, Martinez PA, Capo V, Blanco O, Rodriguez ME, Jimenez N, et al. Kaposi's Sarcoma and Human Herpesvirus 8 in Cuba: Evidence of subtype B expansion. Virology. 2012;432(2):361-9.

Krigel RL, Laubenstein LJ, Muggia FM. Kaposi's sarcoma: a new staging classification. Cancer Treat Rep. 1983;67(6):531-4.

Krishnan HH, Naranatt PP, Smith MS, Zeng L, Bloomer C, Chandran B. Concurrent expression of latent and a limited number of lytic genes with immune modulation and antiapoptotic function by Kaposi's sarcoma-associated herpesvirus early during infection of primary endothelial and fibroblast cells and subsequent decline of lytic gene expression. J Virol. 2004;78(7):3601-20.

Krown SE, Metroka C, Wernz JC. Kaposi's sarcoma in the acquired immune deficiency syndrome: a proposal for uniform evaluation, response, and staging criteria. AIDS Clinical Trials Group Oncology Committee. J Clin Oncol. 1989;7(9):1201-7.

Krown SE, Testa MA, Huang J. AIDS-related Kaposi's sarcoma: prospective validation of the AIDS Clinical Trials Group staging classification. AIDS Clinical Trials Group Oncology Committee. J Clin Oncol. 1997;15(9):3085-92.

Krown SE, Lee JY, Dittmer DP, Consortium AM. More on HIV-associated Kaposi's sarcoma. N Engl J Med. 2008;358(5):535-6. 
Lacoste V, Judde JG, Brière J, Tulliez M, Garin B, Kassa-Kelembho E, et al. Molecular epidemiology of human herpesvirus 8 in africa: both $B$ and A5 K1 genotypes, as well as the $M$ and $P$ genotypes of $K 14.1 / K 15$ loci, are frequent and widespread. Virology. 2000a;278(1):60-74.

Lacoste V, Kadyrova E, Chistiakova I, Gurtsevitch V, Judde JG, Gessain A. Molecular characterization of Kaposi's sarcoma-associated herpesvirus/human herpesvirus-8 strains from Russia. J Gen Virol. 2000b;81:1217-22.

LaDuca JR, Love JL, Abbott LZ, Dube S, Freidman-Kien AE, Poiesz BJ. Detection of human herpesvirus 8 DNA sequences in tissues and bodily fluids. J Infect Dis. 1998;178(6):1610-5.

Lagos $\mathrm{D}$ e Boshoff $\mathrm{C}$. Immunobiology and host response to KSHV infection. In: Arvin A, Campadelli-Fiume G, Mocarski E, Moore PS, Roizman B, Whitley R, Yamanisk K. Editors. Human herpesvirus: Biology, Therapy, and Immunoprophylaxis. Cambridge: Cambrigde University Press; 2007. Chapter 52. [cited 2011 set 12] Available from: http://www.ncbi.nlm.gov.books/NBK47453/

Lagunoff M, Ganem D. The structure and coding organization of the genomic termini of Kaposi's sarcoma-associated herpesvirus. Virology. 1997;236(1):147-54.

Lagunoff M, Majeti R, Weiss A, Ganem D. Deregulated signal transduction by the K1 gene product of Kaposi's sarcoma-associated herpesvirus. Proc Natl Acad Sci U S A. 1999;96(10):5704-9.

Lampinen TM, Kulasingam S, Min J, Borok M, Gwanzura L, Lamb J, et al. Detection of Kaposi's sarcoma-associated herpesvirus in oral and genital secretions of Zimbabwean women. J Infect Dis. 2000;181(5):1785-90.

Larsen C, Bousquet V, Delarocque-Astagneau E, Pioche C, Roudot-Thoraval F, Desenclos $\mathrm{JC}$, et al. Hepatitis $\mathrm{C}$ virus genotype 3 and the risk of severe liver disease in a large population of drug users in France. J Med Virol. 2010;82(10):1647-54.

Leao JC, de Faria AB, Fonseca DD, Gueiros LA, Silva IH, Porter SR. Intrahost genetic variability of human herpes virus-8. J Med Virol. 2013;85(4):636-45.

Lebbe C. Human herpesvirus 8 (HHV-8) and Kaposi sarcoma. Hautarzt. 2008;59(1):18-25.

Lee BS, Alvarez X, Ishido S, Lackner AA, Jung JU. Inhibition of intracellular transport of $B$ cell antigen receptor complexes by Kaposi's sarcoma-associated herpesvirus K1. J Exp Med. 2000;192(1):11-21.

Lee H, Guo J, Li M, Choi JK, DeMaria M, Rosenzweig M, et al. Identification of an immunoreceptor tyrosine-based activation motif of $\mathrm{K} 1$ transforming protein of Kaposi's sarcoma-associated herpesvirus. Mol Cell Biol. 1998;18(9):5219-28. 
Lehrnbecher TL, Foster CB, Zhu S, Venzon D, Steinberg SM, Wyvill K, et al. Variant genotypes of FcgammaRIIIA influence the development of Kaposi's sarcoma in HIVinfected men. Blood. 2000;95(7):2386-90.

Levi JE, Nascimento MC, Sumita LM, de Souza VA, Freire WS, Mayaud P, et al. Non-detection of human herpesvirus 8 (HHV-8) DNA in HHV-8-seropositive blood donors from three Brazilian regions. PLoS One. 2011;6(8):e23546.

Li M, Lee H, Yoon DW, Albrecht JC, Fleckenstein B, Neipel F, et al. Kaposi's sarcoma-associated herpesvirus encodes a functional cyclin. $J$ Virol. 1997;71(3):1984-91.

Li H, Komatsu T, Dezube BJ, Kaye KM. The Kaposi's sarcoma-associated herpesvirus $\mathrm{K} 12$ transcript from a primary effusion lymphoma contains complex repeat elements, is spliced, and initiates from a novel promoter. J Virol. 2002;76(23):11880-8.

Lin YT, Kincaid RP, Arasappan D, Dowd SE, Hunicke-Smith SP, Sullivan CS. Small RNA profiling reveals antisense transcription throughout the KSHV genome and novel small RNAs. RNA. 2010;16(8):1540-58.

Lole KS, Bollinger RC, Paranjape RS, Gadkari D, Kulkarni SS, Novak NG, et al. Fulllength human immunodeficiency virus type 1 genomes from subtype C-infected seroconverters in India, with evidence of intersubtype recombination. J Virol. 1999;73(1):152-60.

Lu CC, Li Z, Chu CY, Feng J, Sun R, Rana TM. MicroRNAs encoded by Kaposi's sarcoma-associated herpesvirus regulate viral life cycle. EMBO Rep. 2010;11(10):784-90.

Mancuso R, Biffi R, Valli M, Bellinvia M, Tourlaki A, Athanasia T, et al. HHV-8 A subtype is associated with rapidly evolving classic Kaposi's sarcoma. J Med Virol. 2008;80(12):2153-60.

Mancuso R, Brambilla L, Agostini S, Biffi R, Hernis A, Guerini FR, et al. Intrafamiliar transmission of Kaposi's sarcoma-associated herpesvirus and seronegative infection in family members of classic Kaposi's sarcoma patients. J Gen Virol. 2011;92(Pt 4):744-51.

Manes TD, Hoer S, Muller WA, Lehner PJ, Pober JS. Kaposi's sarcoma-associated herpesvirus $\mathrm{K} 3$ and $\mathrm{K} 5$ proteins block distinct steps in transendothelial migration of effector memory CD4+ T cells by targeting different endothelial proteins. J Immunol. 2010;184(9):5186-92.

Marshall V, Martró E, Labo N, Ray A, Wang D, Mbisa G, et al. Kaposi sarcoma (KS)associated herpesvirus microRNA sequence analysis and $K S$ risk in a European AIDS-KS case control study. J Infect Dis. 2010;202(7):1126-35. 
Martin DP, Lemey P, Lott M, Moulton V, Posada D, Lefeuvre P. RDP3: a flexible and fast computer program for analyzing recombination. Bioinformatics. 2010;26(19):2462-3.

Martin JN, Ganem DE, Osmond DH, Page-Shafer KA, Macrae D, Kedes DH. Sexual transmission and the natural history of human herpesvirus 8 infection. $\mathrm{N}$ Engl $\mathrm{J}$ Med. 1998;338(14):948-54.

Martin JN, Osmond $\mathrm{DH}$. Invited commentary: determining specific sexual practices associated with human herpesvirus 8 transmission. Am $\mathrm{J}$ Epidemiol. 2000;151(3):225-9.

Martin JN. The epidemiology of KSHV and its association with malignant disease. In: Arvin A, Campadelli-Fiume G, Mocarski E, Moore PS, Poizman B, Whitley R, Yamanisk K., editors. Human Herpesviruses: Biology T, and Immunoprophylaxis. Cambridge: Cambridge University Press; 2007. Chapter 54. [cited 2013 jun 2013] Available from: http://www.ncbi.nlm.nih.gov/books/NBK47381/

Martinez V, Caumes E, Gambotti L, Ittah H, Morini JP, Deleuze J, et al. Remission from Kaposi's sarcoma on HAART is associated with suppression of HIV replication and is independent of protease inhibitor therapy. Br J Cancer. 2006;94(7):1000-6.

Martro E, Bulterys M, Stewart JA, Spira TJ, Cannon MJ, Thacher TD, et al. Comparison of human herpesvirus 8 and Epstein-Barr virus seropositivity among children in areas endemic and non-endemic for Kaposi's sarcoma. J Med Virol. 2004;72(1):126-31.

Masala MV, Carcassi C, Cottoni F, Mulargia M, Contu L, Cerimele D. Classic Kaposi's sarcoma in Sardinia: HLA positive and negative associations. Int $\mathrm{J}$ Dermatol. 2005;44(9):743-5.

Matteoli B, Broccolo F, Scaccino A, Cottoni $F$, Angeloni A, Faggioni A, et al. In vivo and in vitro evidence for an association between the route-specific transmission of HHV-8 and the virus genotype. J Med Virol. 2012;84(5):786-91.

Maurer T, Ponte M, Leslie K. HIV-associated Kaposi's sarcoma with a high CD4 count and a low viral load. N Engl J Med. 2007;357(13):1352-3.

Mbulaiteye SM, Pfeiffer RM, Engels EA, Marshall V, Bakaki PM, Owor AM et al. Detection of Kaposi sarcoma-associated herpesvirus DNA in saliva and buffy coat samples from children with sickle cell disease in Uganda. J. Infect Dis. 2004;190:1382-6.

Mbulaiteye S, Marshall V, Bagni RK, Wang CD, Mbisa G, Bakaki PM, et al. Molecular evidence for mother-to-child transmission of Kaposi sarcoma-associated herpesvirus in Uganda and K1 gene evolution within the host. J Infect Dis. 2006;193(9):1250-7.

McCormick C, Ganem D. The kaposin B protein of KSHV activates the p38/MK2 pathway and stabilizes cytokine mRNAs. Science. 2005;307(5710):739-41. 
Meng YX, Spira TJ, Bhat GJ, Birch CJ, Druce JD, Edlin BR, et al. Individuals from North America, Australasia, and Africa are infected with four different genotypes of human herpesvirus 8. Virology. 1999;261(1):106-19.

Meng YX, Sata T, Stamey FR, Voevodin A, Katano H, Koizumi H, et al. Molecular characterization of strains of Human herpesvirus 8 from Japan, Argentina and Kuwait. J Gen Virol. 2001;82(Pt 3):499-506.

Mercader M, Taddeo B, Panella JR, Chandran B, Nickoloff BJ, Foreman KE. Induction of HHV-8 lytic cycle replication by inflammatory cytokines produced by HIV1-infected T cells. Am J Pathol. 2000;156(6):1961-71.

Mesri EA, Cesarman E, Boshoff C. Kaposi's sarcoma and its associated herpesvirus. Nat Rev Cancer. 2010;10(10):707-19.

Miller CS, Berger JR, Mootoor Y, Avdiushko SA, Zhu H, Kryscio RJ. High prevalence of multiple human herpesviruses in saliva from human immunodeficiency virusinfected persons in the era of highly active antiretroviral therapy. $J$ Clin Microbiol. 2006;44(7):2409-15.

Miller G, Rigsby MO, Heston L, Grogan E, Sun R, Metroka C, et al. Antibodies to butyrate-inducible antigens of Kaposi's sarcoma-associated herpesvirus in patients with HIV-1 infection. N Engl J Med. 1996;334(20):1292-7.

Mitsuyasu RT, Groopman JE. Biology and therapy of Kaposi's sarcoma. Semin Oncol. 1984;11(1):53-9.

Montagnino G, Bencini PL, Tarantino A, Caputo R, Ponticelli C. Clinical features and course of Kaposi's sarcoma in kidney transplant patients: report of 13 cases. Am J Nephrol. 1994;14(2):121-6.

Moore PS, Boshoff C, Weiss RA, Chang Y. Molecular mimicry of human cytokine and cytokine response pathway genes by KSHV. Science. 1996c;274(5293):1739-44.

Moore PS, Gao SJ, Dominguez G, Cesarman E, Lungu O, Knowles DM, et al. Primary characterization of a herpesvirus agent associated with Kaposi's sarcomae. J Virol. 1996b;70(1):549-58.

Moore PS, Kingsley LA, Holmberg SD, Spira T, Gupta P, Hoover DR, et al. Kaposi's sarcoma-associated herpesvirus infection prior to onset of Kaposi's sarcoma. AIDS. 1996a;10(2):175-80.

Moore PS. The emergence of Kaposi's sarcoma-associated herpesvirus (human herpesvirus 8). N Engl J Med. 2000;343(19):1411-3.

Moore PS, Chang Y. Molecular virology of Kaposi's sarcoma-associated herpesvirus. Philos Trans R Soc Lond Biol Sci. 2001;356(1408):499-516. 
Moritz Kaposi. Idiopathisches multiples pigment sarcom der haut. Arch Dermatol Syph. 1872;4.

Muralidhar S, Pumfery AM, Hassani M, Sadaie MR, Kishishita M, Brady JN, et al.

Identification of kaposin (open reading frame K12) as a human herpesvirus 8 (Kaposi's sarcoma-associated herpesvirus) transforming gene. J Virol. 1998; 72(6):4980-8.

Muralidhar S, Veytsmann G, Chandran B, Ablashi D, Doniger J, Rosenthal LJ. Characterization of the human herpesvirus 8 (Kaposi's sarcoma-associated herpesvirus) oncogene, kaposin (ORF K12). J Clin Virol. 2000;16(3):203-13.

Murphy M, Armstrong D, Sepkowitz KA, Ahkami RN, Myshowshi PL. Regression of AIDS-related Kaposi's sarcoma following treatment with an HIV-1 protease inhibitor. AIDS. 1997;11(2):261-2.

Myers BD, Kessler E, Levi J, Pick A, Rosenfeld JB, Tikvah P. Kaposi sarcoma in kidney transplant recipients. Arch Intern Med. 1974;133(2):307-11.

Nakamura H, Li M, Zarycki J, Jung JU. Inhibition of p53 tumor suppressor by viral interferon regulatory factor. J Virol. 2001;75(16):7572-82.

Nascimento MC, de Souza VA, Sumita LM, Freire W, Munoz F, Kim J, et al. Comparative study of Kaposi's sarcoma-associated herpesvirus serological assays using clinically and serologically defined reference standards and latent class analysis. J Clin Microbiol. 2007;45(3):715-20.

Nascimento MC, Wilder N, Pannuti CS, Weiss HA, Mayaud P. Molecular characterization of Kaposi's sarcoma associated herpesvirus (KSHV) from patients with AIDS-associated Kaposi's sarcoma in Sao Paulo, Brazil. J Clin Virol. 2005;33(1):52-9.

Nasti G, Talamini R, Antinori A, Martellotta F, Jacchetti G, Chiodo F, et al. AIDSrelated Kaposi's Sarcoma: evaluation of potential new prognostic factors and assessment of the AIDS Clinical Trial Group Staging System in the Haart Era--the Italian Cooperative Group on AIDS and Tumors and the Italian Cohort of Patients Naive From Antiretrovirals. J Clin Oncol. 2003;21(15):2876-82.

Neipel F, Albrecht JC, Fleckenstein B. Cell-homologous genes in the Kaposi's sarcoma-associated rhadinovirus human herpesvirus 8: determinants of its pathogenicity? J Virol. 1997;71(6):4187-92.

Newton R, Ziegler J, Bourboulia D, Casabonne D, Beral V, Mbidde E, et al. The seroepidemiology of Kaposi's sarcoma-associated herpesvirus (KSHV/HHV-8) in adults with cancer in Uganda. Int J Cancer. 2003;103(2):226-32. 
Nguyen HQ, Magaret AS, Kitahata MM, Van Rompaey SE, Wald A, Casper C. Persistent Kaposi sarcoma in the era of highly active antiretroviral therapy: characterizing the predictors of clinical response. AIDS. 2008;22(8):937-45.

Nguyen ML, Farrell KJ, Gunthel CJ. Non-AIDS-Defining Malignancies in Patients with HIV in the HAART Era. Curr Infect Dis Rep. 2010;12(1):46-55.

Nicholas J. Human gammaherpesvirus cytokines and chemokine receptors. J Interferon Cytokine Res. 2005;25(7):373-83.

Nicholas J, Zong JC, Alcendor DJ, Ciufo DM, Poole LJ, Sarisky RT, et al. Novel organizational features, captured cellular genes, and strain variability within the genome of KSHV/HHV8. J Natl Cancer Inst Monogr. 1998(23):79-88.

Oettlé AG. Geographical and racial differences in the frequency of Kaposi's sarcoma as evidence of environmental or genetic causes. Acta Unio Int Contra Cancrum. 1962;18:330-63.

Olsen SJ, Chang Y, Moore PS, Biggar RJ, Melbye M. Increasing Kaposi's sarcomaassociated herpesvirus seroprevalence with age in a highly Kaposi's sarcoma endemic region, Zambia in 1985. AIDS. 1998;12(14):1921-5.

Orenstein JM. Ultrastructure of Kaposi sarcoma. Ultrastruct Pathol. 2008;32(5):211-20.

Parkin DM. The global health burden of infection-associated cancers in the year 2002. Int J Cancer. 2006;118(12):3030-44.

Pauk J, Huang ML, Brodie SJ, Wald A, Koelle DM, Schacker T, et al. Mucosal shedding of human herpesvirus 8 in men. N Engl J Med. 2000;343(19):1369-77.

Pellett PE, Wright DJ, Engels EA, Ablashi DV, Dollard SC, Forghani B, et al. Retrovirus Epidemiology Donor Study. Multicenter comparison of serologic assays and estimation of human herpesvirus 8 seroprevalence among US blood donors. Transfusion. 2003;43(9):1260-8.

Pellet PE and Roizman B. The family Herpesviridae: a brief introduction. In: Knipe DM, Howley PM, editors. Fields Virology. Philadelphia: Lippincott Williams and Wilkins; 2007. p. 2479-500.

Penn I. Kaposi's sarcoma in immunosuppressed patients. J Clin Lab Immunol. 1983;12(1):1-10.

Pfeffer S, Sewer A, Lagos-Quintana M, Sheridan R, Sander C, Grässer FA, et al. Identification of microRNAs of the herpesvirus family. Nat Methods. 2005;2(4):269-76. 
Pierrotti LC, Sumita LM, Freire WS, Caiaffa HH, de Souza V. Detection of human herpesvirus 8 DNA and antibodies to latent nuclear and lytic-phase antigens in serial samples from aids patients with Kaposi's sarcoma. J Clin Virol. 2000;16(3):247-51.

Pierrotti LC. Fatores de risco para ocorrência de virêmia pelo Herpesvírus 8 Humano em pacientes com aids e sarcoma de Kaposi [Tese ]. São Paulo: Faculdade de Medicina da Universidade de São Paulo; 2004.

Plaisance-Bonstaff K, Renne R. Viral miRNAs. Methods Mol Biol. 2011;721:43-66.

Plancoulaine S, Abel L, van Beveren M, Trégouët DA, Joubert $M$, Tortevoye $P$, de Thé $G$, Gessain A. Human herpesvirus 8 transmission from mother to child and between siblings in an endemic population. Lancet. 2000;356(9235):1062-5.

Plancoulaine S, Gessain A, van Beveren M, Tortevoye P, Abel L. Evidence for a recessive major gene predisposing to human herpesvirus 8 (HHV-8) infection in a population in which HHV-8 is endemic. J Infect Dis. 2003;187(12):1944-50.

Polizzotto MN, Uldrick TS, Hu D, Yarchoan R. Clinical Manifestations of Kaposi Sarcoma Herpesvirus Lytic Activation: Multicentric Castleman Disease (KSHV-MCD) and the KSHV Inflammatory Cytokine Syndrome. Front Microbiol. 2012;3:73.

Poole LJ, Zong JC, Ciufo DM, Alcendor DJ, Cannon JS, Ambinder R, et al. Comparison of genetic variability at multiple loci across the genomes of the major subtypes of Kaposi's sarcoma-associated herpesvirus reveals evidence for recombination and for two distinct types of open reading frame $\mathrm{K} 15$ alleles at the right-hand end. J Virol. 1999;73(8):6646-60.

Portsmouth S, Stebbing J, Gill J, Mandalia S, Bower M, Nelson M, et al. A comparison of regimens based on non-nucleoside reverse transcriptase inhibitors or protease inhibitors in preventing Kaposi's sarcoma. AIDS. 2003;17(11):F17-22.

Posada D, Crandall KA. MODELTEST: testing the model of DNA substitution. Bioinformatics. 1998;14(9):817-8.

Prakash O, Swamy OR, Peng X, Tang ZY, Li L, Larson JE, et al. Activation of Src kinase Lyn by the Kaposi sarcoma-associated herpesvirus K1 protein: implications for lymphomagenesis. Blood. 2005;105(10):3987-94.

Pyakurel P, Pak F, Mwakigonja AR, Kaaya E, Heiden T, Biberfeld P. Lymphatic and vascular origin of Kaposi's sarcoma spindle cells during tumor development. Int $\mathrm{J}$ Cancer. 2006;119(6):1262-7.

Ramalingam D, Kieffer-Kwon P, Ziegelbauer JM. Emerging Themes from EBV and KSHV microRNA Targets. Virusesl. 2012;4(9):1687-710. 
Ramos da Silva SR, da Silva APF, Bacchi MM, Bacchi CE, de Oliveira DE. KSHV genotypes $A$ and $C$ are more frequent in Kaposi sarcoma lesions from Brazilian patients with and without HIV infection, respectively. Cancer Lett. 2011;301(1):85-94.

Ray A, Marshall V, Uldrick T, Leighty R, Labo N, Wyvill K, et al. Sequence analysis of Kaposi sarcoma-associated herpesvirus (KSHV) microRNAs in patients with multicentric Castleman disease and KSHV-associated inflammatory cytokine syndrome. J Infect Dis. 2012;205(11):1665-76.

Renne R, Zhong W, Herndier B, McGrath M, Abbey N, Kedes D, et al. Lytic growth of Kaposi's sarcoma-associated herpesvirus (human herpesvirus 8 ) in culture. Nat Med. 1996;2(3):342-6.

Restrepo CS, Ocazionez D. Kaposi's Sarcoma: Imaging Overview. Semin Ultrasound CT MR. 2011;32(5):456-69.

Rezaee SA, Cunningham C, Davison AJ, Blackbourn DJ. Kaposi's sarcomaassociated herpesvirus immune modulation: an overview. J Gen Virol. 2006;87(Pt 7):1781-804.

Roth WK, Brandstetter $H$, Stürzl $M$. Cellular and molecular features of HIVassociated Kaposi's sarcoma. AIDS. 1992;6(9):895-913.

Russo JJ, Bohenzky RA, Chien MC, Chen J, Yan M, Maddalena D, et al. Nucleotide sequence of the Kaposi sarcoma-associated herpesvirus (HHV8). Proc Natl Acad Sci U S A. 1996;93(25):14862-7.

Sadler R, Wu L, Forghani B, Renne R, Zhong W, Herndier B, et al. A complex translational program generates multiple novel proteins from the latently expressed kaposin (K12) locus of Kaposi's sarcoma-associated herpesvirus. J Virol. 1999;73(7):5722-30.

Safai B, Good RA. Kaposi's sarcoma: a review and recent developments. CA Cancer J Clin. 1981;31(1):2-12.

Safai B, Johnson KG, Myskowski PL, Koziner B, Yang SY, Cunningham-Rundles S, et al. The natural history of Kaposi's sarcoma in the acquired immunodeficiency syndrome. Ann Intern Med. 1985;103(5):744-50.

Samols MA, Hu J, Skalsky RL, Renne R. Cloning and identification of a microRNA cluster within the latency-associated region of Kaposi's sarcoma-associated herpesvirus. J Virol. 2005;79(14):9301-5.

Santos Fortuna E. Herpes Humano Tipo 8: estudo de segmentos alvo no genoma viral em amostras de sangue, saliva e urina de pacientes infectados por HIV/aids com e sem sarcoma de Kaposi [tese ]. São Paulo: Faculdade de Ciências Farmacêuticas da Universidade de São Paulo; 2005. 
São Paulo (SP). Prefeitura de São Paulo, Coordenação de Vigilância em Saúde Banco de dados/Tabnet_2010 [citado 2013 jul 11]. Disponível em: ww2.prefeitura.sp.gov.br/ tabnet 2010.

Sato K, Yanagisawa M, Hashizume H, Yamazaki Y, Horiguchi N, Kakizaki S, et al. Extended therapy duration for therapy-refractory hepatitis $C$ patients with genotype 2 . World J Gastroenterol. 2013;19(34):5754-8.

Schulz TF. Epidemiology of Kaposi's sarcoma-associated herpesvirus/human herpesvirus 8. Adv Cancer Res. 1999;76:121-60.

Schwartz RA, Micali G, Rita M, Scuderi L. Kaposi sarcoma: A continuing conundrum. Journal of the American Academy of Dermatology. 2008;59(2):179-206.

Seaberg EC, Wiley D, Martínez-Maza O, Chmiel JS, Kingsley L, Tang Y, et al. Cancer incidence in the multicenter AIDS Cohort Study before and during the HAART era: 1984 to 2007. Cancer. 2010;116(23):5507-16.

Semeere AS, Busakhala N, Martin JN. Impact of antiretroviral therapy on the incidence of Kaposi's sarcoma in resource-rich and resource-limited settings. Curr Opin Oncol. 2012;24(5):522-30.

Sergei L. Kosakovsky Pond and Simon D. W. Frost Datamonkey: rapid detection of selective pressure on individual sites of codon alignments. 2005; Bioinformatics 21(10): 2531-3.

Serwadda D, Carswell W, Ayuko WO, Wamukota W, Madda P, Downing RG. Further experience with Kaposi's sarcoma in Uganda. Br J Cancer. 1986;53(4):497-500.

Sinfield RL, Molyneux EM, Banda K, Borgstein E, Broadhead R, Hesseling P, et al. Spectrum and presentation of pediatric malignancies in the HIV era: experience from Blantyre, Malawi, 1998-2003. Pediatr Blood Cancer. 2007;48(5):515-20.

Slavin G, Cameron HM, Forbes C, Mitchell RM. Kaposi's sarcoma in East African children: a report of 51 cases. J Pathol. 1970;100(3):187-99.

Souza VA, Salzano FM, Petzl-Erler ML, Nascimento MC, Mayaud P, Borges JD, et al. Variations in Human Herpesvirus Type 8 Seroprevalence in Native Americans, South America. Emerging Infectious Diseases. 2010;16(6):1003-6.

Souza VA, Sumita LM, Freire W, Sato HK, Grandi JL, Pierrotti LC, et al. Prevalence of antibodies to human herpesvirus-8 in populations with and without risk for infection in São Paulo State. Braz J Med Biol Res. 2004;37(1):123-7. 
Souza VA, Pierrotti LC, Sumita LM, Freire WS, Segurado AA, Pannuti CS. Seroreactivity to Kaposi's sarcoma-associated herpesvirus (human herpesvirus 8) latent nuclear antigen in AIDS-associated Kaposi's sarcoma patients depends on CD4+ T-cell count. J Med Virol. 2007a;79(10):1562-8.

Souza VA, Sumita LM, Nascimento MC, Oliveira J, Mascheretti M, Quiroga M, et al. Human herpesvirus-8 infection and oral shedding in Amerindian and non-Amerindian populations in the Brazilian Amazon region. J Infect Dis. 2007b;196(6):844-52.

Spiller OB, Robinson M, O'Donnell E, Milligan S, Morgan BP, Davison AJ, et al. Complement regulation by Kaposi's sarcoma-associated herpesvirus ORF4 protein. J Virol. 2003;77(1):592-9.

Stebbing J, Bourboulia D, Johnson M, Henderson S, Williams I, Wilder N, et al. Kaposi's sarcoma-associated herpesvirus cytotoxic $T$ lymphocytes recognize and target Darwinian positively selected autologous K1 epitopes. J Virol. 2003;77(7):4306-14.

Stebbing J, Powles T, Bower M. AIDS-associated Kaposi's sarcoma associated with a low viral load and a high CD4 cell count. AIDS. 2008;22(4):551-2.

Strathdee SA, Veugelers PJ, Moore PS. The epidemiology of HIV-associated Kaposi's sarcoma: the unraveling mystery. AIDS. 1996;10 Suppl A:S51-7.

Stribling J, Weitzner S, Smith GV. Kaposi's sarcoma in renal allograft recipients. Cancer. 1978;42(2):442-6.

Sunil M, Reid E, Lechowicz MJ. Update on HHV-8-Associated Malignancies. Curr Infect Dis Rep. 2010;12(2):147-54.

Tamburro KM, Yang DM, Poisson J, Fedoriw Y, Roy D, Lucas A, et al. Vironome of Kaposi sarcoma associated herpesvirus-inflammatory cytokine syndrome in an AIDS patient reveals co-infection of human herpesvirus 8 and human herpesvirus 6A. Virology. 2012;433(1):220-5.

Tamura K, Peterson D, Peterson N, Stecher G, Nei M, Kumar S. MEGA5: Molecular Evolutionary Genetics Analysis using Maximum Likelihood, Evolutionary Distance, and Maximum Parsimony Methods. Mol Biol Evol. 2011; 28(10):2731-9.

Taniguchi T, Takaoka A. The interferon-alpha/beta system in antiviral responses: a multimodal machinery of gene regulation by the IRF family of transcription factors. Curr Opin Immunol. 2002;14(1):111-6. 
Tedeschi R, Enbom M, Bidoli E, Linde A, De Paoli P, Dillner J. Viral load of human herpesvirus 8 in peripheral blood of human immunodeficiency virus-infected patients with Kaposi's sarcoma. J Clin Microbiol. 2001;39(12):4269-73.

Templeton AC. Kaposi's sarcoma. Pathol Annu. 1981;16(Pt 2):315-36.

Tessari G, Naldi L, Boschiero L, Cordiano C, Piaserico S, Fortina AB, et al. Incidence and clinical predictors of Kaposi's sarcoma among 1721 Italian solid organ transplant recipients: a multicenter study. Eur J Dermatol. 2006;16(5):553-7.

Tessari G, Naldi L, Boschiero L, Minetti E, Sandrini S, Nacchia F, et al. Incidence of primary and second cancers in renal transplant recipients: a multicenter cohort study. Am J Transplant. 2013;13(1):214-21.

Thome M, Schneider P, Hofmann K, Fickenscher H, Meinl E, Neipel F, et al. Viral FLICE-inhibitory proteins (FLIPs) prevent apoptosis induced by death receptors. Nature. 1997;386(6624):517-21.

Tomlinson CC, Damania B. The K1 protein of Kaposi's sarcoma-associated herpesvirus activates the Akt signaling pathway. J Virol. 2004;78(4):1918-27.

Tornesello ML, Biryahwaho B, Downing R, Hatzakis A, Alessi E, Cusini M, et al. Human herpesvirus type 8 variants circulating in Europe, Africa and North America in classic, endemic and epidemic Kaposi's sarcoma lesions during pre-AIDS and AIDS era. Virology. 2010;398(2):280-9.

Triantos D, Horefti E, Paximadi E, Kyriakopoulou Z, Karakassiliotis G, Papanastasiou $\mathrm{K}$, et al. Presence of human herpes virus-8 in saliva and non-lesional oral mucosa in HIV-infected and oncologic immunocompromised patients. Oral Microbiol Immunol. 2004;19(3):201-4.

Uldrick TS, Polizzotto MN, Yarchoan R. Recent advances in Kaposi sarcoma herpesvirus-associated multicentric Castleman disease. Curr Opin Oncol. 2012;24(5):495-505.

Uldrick TS, Wang V, O'Mahony D, Aleman K, Wyvill KM, Marshall V, et al. An interleukin-6-related systemic inflammatory syndrome in patients co-infected with Kaposi sarcoma-associated herpesvirus and HIV but without Multicentric Castleman disease. Clin Infect Dis. 2010;51(3):350-8.

Uldrick TS, Whitby D. Update on KSHV epidemiology, Kaposi Sarcoma pathogenesis, and treatment of Kaposi Sarcoma. Cancer Lett. 2011;305(2):150-62.

van Kessel A, Quint KD. [Moritz Kaposi and his sarcoma]. Ned Tijdschr Geneeskd. 2011;155(45):A3879. 
Vieira J, Huang ML, Koelle DM, Corey L. Transmissible Kaposi's sarcoma-associated herpesvirus (human herpesvirus 8) in saliva of men with a history of Kaposi's sarcoma. J Virol. 1997;71(9):7083-7.

Vieira J, O'Hearn PM. Use of the red fluorescent protein as a marker of Kaposi's sarcoma-associated herpesvirus lytic gene expression. Virology. 2004;325(2):225-40.

Viejo-Borbolla A, Ottinger M, Brüning $E$, Bürger $A$, König R, Kati $E$, et al. Brd2/RING3 interacts with a chromatin-binding domain in the Kaposi's Sarcoma-associated herpesvirus latency-associated nuclear antigen 1 (LANA-1) that is required for multiple functions of LANA-1. J Virol. 2005;79(21):13618-29.

Vitale F, Viviano E, Perna AM, Bonura F, Mazzola G, Ajello F, et al. Serological and virological evidence of non-sexual transmission of human herpesvirus type 8 (HHV8). Epidemiol Infect. 2000;125(3):671-5.

Wabinga HR, Parkin DM, Wabwire-Mangen F, Mugerwa JW. Cancer in Kampala, Uganda, in 1989-91: changes in incidence in the era of AIDS. Int $\mathrm{J}$ Cancer. 1993;54(1):26-36.

Wang HW, Trotter MW, Lagos D, Bourboulia D, Henderson S, Mäkinen T, et al. Kaposi sarcoma herpesvirus-induced cellular reprogramming contributes to the lymphatic endothelial gene expression in Kaposi sarcoma. Nat Genet. 2004;36(7):687-93.

Wang L, Dittmer DP, Tomlinson CC, Fakhari FD, Damania B. Immortalization of primary endothelial cells by the $\mathrm{K} 1$ protein of Kaposi's sarcoma-associated herpesvirus. Cancer Res. 2006;66(7):3658-66.

Wen KW, Damania B. Kaposi sarcoma-associated herpesvirus (KSHV): molecular biology and oncogenesis. Cancer Lett. 2010;289(2):140-50.

Whitby D, Howard MR, Tenant-Flowers M, Brink NS, Copas A, Boshoff C, et al. Detection of Kaposi sarcoma associated herpesvirus in peripheral blood of HIVinfected individuals and progression to Kaposi's sarcoma. Lancet. 1995;346(8978):799-802.

Whitby D, Marshall VA, Bagni RK, Miley WJ, McCloud TG, Hines-Boykin R, et al. Reactivation of Kaposi's sarcoma-associated herpesvirus by natural products from Kaposi's sarcoma endemic regions. Int J Cancer. 2007;120(2):321-8.

Whitby D, Marshall VA, Bagni RK, Wang CD, Gamache CJ, Guzman JR, et al. Genotypic characterization of Kaposi's sarcoma-associated herpesvirus in asymptomatic infected subjects from isolated populations. J Gen Virol. 2004;85(Pt 1):155-63. 
White T, Hagen M, Gudza I, White IE, Ndemera B, Gwanzura L, et al. Genetic diversity of the Kaposi's sarcoma herpesvirus K1 protein in AIDS-KS in Zimbabwe. J Clin Virol. 2008;42(2):165-71.

Wilkinson J, Cope A, Gill J, Bourboulia D, Hayes P, Imami N, et al. Identification of Kaposi's sarcoma-associated herpesvirus (KSHV)-specific cytotoxic T-lymphocyte epitopes and evaluation of reconstitution of KSHV-specific responses in human immunodeficiency virus type 1 -Infected patients receiving highly active antiretroviral therapy. J Virol. 2002;76(6):2634-40.

Zago A, Bourboulia D, Viana MC, Collandre H, Dietze R, Boshoff $C$, et al. Seroprevalence of human herpesvirus 8 and its association with Kaposi sarcoma in Brazil. Sex Transm Dis. 2000;27(8):468-72.

Zhang D, Pu X, Wu W, Jin Y, Juhear M, Wu X. Genotypic analysis on the ORF-K1 gene of human herpesvirus 8 from patients with Kaposi's sarcoma in Xinjiang, China. J Genet Genomics. 2008;35(11):657-63.

Zhang XQ, Fitzpatrick L, Campbell TB, Badaro R, Schechter M, Meio MD, et al. Comparison of the prevalence of antibodies to human herpesvirus 8 (Kaposi's sarcoma-associated herpesvirus) in Brazil and Colorado. J Infect Dis. 1998;178(5):1488-91.

Zhong W, Wang H, Herndier B, Ganem D. Restricted expression of Kaposi sarcomaassociated herpesvirus (human herpesvirus 8) genes in Kaposi sarcoma. Proc Natl Acad Sci U S A. 1996;93(13):6641-6.

Zhou F, Xue M, Qin D, Zhu X, Wang C, Zhu J, et al. HIV-1 Tat promotes Kaposi's sarcoma-associated herpesvirus (KSHV) vIL-6-induced angiogenesis and tumorigenesis by regulating PI3K/PTEN/AKT/GSK-3 $\beta$ signaling pathway. PLoS One. 2013;8(1):e53145.

Zhu FX, King SM, Smith EJ, Levy DE, Yuan Y. A Kaposi's sarcoma-associated herpesviral protein inhibits virus-mediated induction of type I interferon by blocking IRF-7 phosphorylation and nuclear accumulation. Proc Natl Acad Sci U S A. 2002;99(8):5573-8.

Ziegelbauer JM. Functions of Kaposi's sarcoma-associated herpesvirus microRNAs. Biochim Biophys Acta. 2011;1809(11-12):623-30.

Zong JC, Arav-Boger R, Alcendor DJ, Hayward GS. Reflections on the interpretation of heterogeneity and strain differences based on very limited PCR sequence data from Kaposi's sarcoma-associated herpesvirus genomes. Journal of Clinical Virology. 2007;40(1):1-8. 
Zong JC, Ciufo DM, Alcendor DJ, Wan X, Nicholas J, Browning PJ, et al. High-level variability in the ORF-K1 membrane protein gene at the left end of the Kaposi's sarcomaassociated herpesvirus genome defines four major virus subtypes and multiple variants or clades in different human populations. J Virol. 1999;73(5):4156-70.

Zong J, Ciufo DM, Viscidi R, Alagiozoglou L, Tyring S, Rady P, et al. Genotypic analysis at multiple loci across Kaposi's sarcoma herpesvirus (KSHV) DNA molecules: clustering patterns, novel variants and chimerism. $\mathrm{J}$ Clin Virol. 2002;23(3):119-48.

Zong JC, Metroka C, Reitz MS, Nicholas J, Hayward GS. Strain variability among Kaposi sarcoma-associated herpesvirus (human herpesvirus 8) genomes: Evidence that a large cohort of United States AIDS patients may have been infected by a single common isolate. J Virol. 1997;71(3):2505-11. 


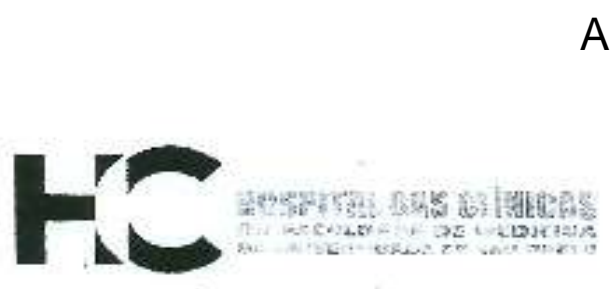

ANEXO I

\section{APROVAÇĀO}

A Comissão de Ética para Análise de Projelos de Pesquisa CAPposa da Dirctoria Clinica do Hospital das Clínicas da Faculdade de medicina da Universidade de São Paulo, em sessão de 25/05/2011. APROVOU o Protocolo de Pesqijisr $n$ " 02\%0/17, intitulado: "VARIAGILIDADE GENÉtICA DO HERPESVIRUS \& HUMANO (HHVB) E EVOLUÇĀO CLÍNICA DO SARCOMA DE KAPOSI AS5OCIADO A AIDS. COMPARAÇO COM GENOTIPOS DE HHVB DE PACIENTES INFECTADOS POR HIV SEM SK E NĀO INFECTADOS POR HIV TRANSPLANTADOS RENAIS. " apresentado pelo Depurtamento de MOLÉSTIAS INFECCIOSAS E PARASITARIAS, inclusive o Termo de Conseritimento Lire esciarecico.

Cabe ao pesquisador elaborar e apresertar a CAPPesq. os relatórios parcicis e final soore a pesquisa (Resoluço do Conselho Nacional de Scúde $1^{\circ} 196$. de $10 / 10 / 1996$, inciso $1 \times .2$, lel a "c").

Pesquisacior iç Responsável: Vanda Akico Ueda Fick de Souza

Pesquisucur (j) Execulunte. Tania Regina Tozetto Mendoza

Co-ajtores: Cláudlo Sérgla Pannull, LIgla Camera PIerrotti

CAPPesq. 25 ds Maio de 2011



PROF. DR. EUCLIDES AYRES DE CASTILHO

Coordenador

Comissäo de Élica para Análise de

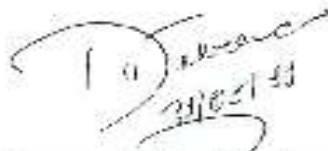

Projetos de Pesquiso - CAPPesq

Camiasa de Etica para Ánalise dá Projetos de Peaquise do HCFlaUSP de Diretorla Cilnica do Haspital des Clinicas da Faculdade de Medicina da Uciversidade ce Sap Paulo Rua Su dio Pires de Carrigus، 225. $5^{\circ}$

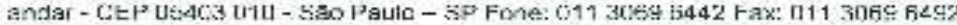

t:-mail: tappesqaghcnet.usp.\$ 